\title{
Cambrian through Mississippian Rocks of the Powder River Basin, Wyoming, Montana, and Adjacent Areas
}

\section{U.S. GEOLOGICAL SURVEY BULLETIN 1917-M}

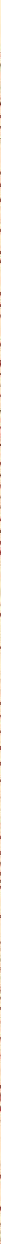



Chapter M

\title{
Cambrian through Mississippian Rocks of the Powder River Basin, Wyoming, Montana, and Adjacent Areas
}

\author{
By DAVID L. MACKE
}

A multidisciplinary approach to research studies of sedimentary rocks and their constituents and the evolution of sedimentary basins, both ancient and modern 


\title{
U.S. DEPARTMENT OF THE INTERIOR BRUCE BABBITT, Secretary
}

\section{U.S. GEOLOGICAL SURVEY}

Robert M. Hirsch, Acting Director

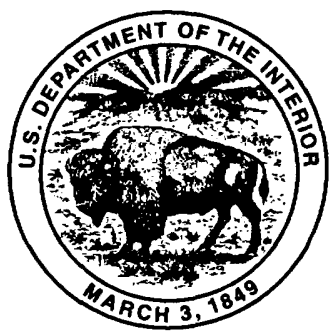

Published in the Central Region, Denver, Colorado

Manuscript approved for publication March 19, 1993

Edited by Judith Stoeser

Graphics prepared by Gayle Dumonceaux

Photocomposition by Shelly A. Fields

Any use of trade, product, or firm names in this publication is for descriptive purposes only and does not imply endorsement by the U. S. Government.

UNITED STATES GOVERNMENT PRINTING OFFICE: 1993

\author{
For sale by \\ USGS Map Distribution \\ Box 25286, Building 810 \\ Denver Federal Center \\ Denver, CO 80225
}

\section{Library of Congress Cataloging-in-Publication Data}

Macke, David L.

Cambrian through Mississippian rocks of the Powder River Basin, Wyoming, Montana, and adjacent areas / by David L. Macke.

p. cm. - (U.S. Geological Survey bulletin ; 1917)

(Evolution of sedimentary basins-Powder River Basin ; ch. M)

Includes bibliographical references.

1. Geology, Stratigraphic-Paleozoic. 2. Rocks, Carbonate-Powder River Basin (Wyo. and Mont.) I. Title. II. Series. III. Series: Evolution of sedimentary basins-Powder River Basin ; ch. $M$.

QE75.B9 no. 1917-M

[QE654]

$557.3 \mathrm{~s}-\mathrm{dc} 20$

[551.7'2'097863|

92-15519 


\title{
CONTENTS
}

\author{
Abstract M1 \\ Introduction M1 \\ Scope of study $\quad$ M3 \\ Stratigraphic sequences M3 \\ Subsurface cross sections M6 \\ Paleobiological changes $\quad$ M8 \\ Paleotectonic setting M8
}

Stratigraphic sequence one-Middle Cambrian through Lower Ordovician rocks $\quad$ M12

Cambrian through Early Ordovician regional tectonics $\quad$ M12

Paleobiological controls on sedimentation $\quad$ M17

Stratigraphic units of sequence one M17

Flathead Sandstone M26

Isopach map M26

Regional lithology and stratigraphy M26

Wolsey Shale and Meagher Limestone equivalent $\quad$ M28

Isopach map $\quad$ M28

Regional lithology and stratigraphy $\quad$ M30

Park Shale and Pilgrim (Du Noir) Limestone equivalent M31

Isopach map M32

Regional lithology and stratigraphy $\quad$ M32

Snowy Range Formation equivalent M34

Isopach map M35

Regional lithology and stratigraphy M35

Deadwood Formation M37

Cambrian through Early Ordovician structural trends $\quad$ M38

Stratigraphic sequence two-Middle Ordovician through Silurian rocks $\quad \mathbf{M 4 0}$

Middle Ordovician through Silurian regional tectonics $\quad$ M40

Paleobiological controls on sedimentation M46

Stratigraphic units of sequence two M48

Winnipeg Formation M49

Lower part of the Winnipeg Formation M51

Upper part of the Winnipeg Formation $\quad$ M53

Bighorn Dolomite and Red River and Whitewood Formations $\quad$ M53

Silurian rocks M63

Middle Ordovician through Silurian structural trends $\quad$ M65

Stratigraphic sequences three, four, and five-Devonian through Mississippian rocks $\quad$ M67

Devonian through Mississippian regional tectonics $\quad$ M70

Paleobiological controls on sedimentation $\quad$ M77

Stratigraphic units of sequence three $\quad \mathbf{M 7 7}$

Middle Devonian rocks $\quad$ M79

Upper Devonian rocks $\quad$ M79

Maywood, Jefferson, Souris River, and Duperow Formations

Three Forks Formation M81

Logan Gulch and Trident Members $\quad$ M81

Beirdneau Formation $\mathbf{M 8 2}$

Darby Formation $\quad \mathbf{M 8 2}$

Stratigraphic units of sequence four $\mathbf{M 8 2}$

Basal clastic unit in the Powder River Basin area $\mathbf{M 8 5}$

Bakken and Exshaw Formations $\quad$ M94

Paine Member of the Madison and Lodgepole Limestones M95 
Lodgepole Limestone M95

Mission Canyon Limestone M95

Charles Formation M96

Madison Limestone (Group) marker system $\quad$ M96

Devonian through Mississippian structural trends $\mathbf{M 1 1 2}$

Stratigraphic units of sequence five M139

Kibbey Formation $\quad$ M143

Otter Formation M143

Heath Formation $\mathbf{M 1 4 3}$

Darwin Sandstone Member of the Amsden Formation $\quad$ M143

Porosity trends and petroleum geology M145

Conclusions M147

Selected references $\mathbf{M 1 6 2}$

PLATES

[Plates are in pocket]

1,2. Cross sections of lower Paleozoic rocks in the Powder River Basin and adjacent areas, Wyoming, Montana, and South Dakota.

\section{FIGURES}

1. Index map showing location of Powder River Basin and adjacent tectonic features M2

2. Chart showing generalized stratigraphic nomenclature and sequences in PowderRiver Basin and adjacent areas M4

3. Map showing location of lines of sections and area of isopach and facies maps $\quad \mathbf{M 7}$

4. Cross sections of lower Paleozoic rocks $\mathbf{M 8}$

5. Map showing crustal formation-age provinces M11

6. Chart showing detailed stratigraphic units and fossil zones of stratigraphic sequence one (Cambrian and Lower Ordovician) $\quad$ M13

7-11. Maps showing:

7. Isopachs of stratigraphic sequence one M14

8. Maximum original eastward extent of Cambrian stages M15

9. Paleogeography during maximum extent of stratigraphic sequence one (Early Ordovician) M16

10. Paleogeography during regression at end of stratigraphic sequence one (early Middle Ordovician) M18

11. Lithology of stratigraphic sequence one M20

12. Schematic cross sections of stratigraphic sequence one M24

13. Drawing showing configuration of basement at end of stratigraphic sequence one M25

14-18. Maps showing:

14. Isopachs of Flathead Sandstone M27

15. Isopachs of combined Flathead Sandstone-Wolsey Shale-Meagher Limestone equivalent interval M29

16. Isopachs of Park Shale-Pilgrim Limestone equivalent interval M33

17. Isopachs of Snowy Range Formation equivalent interval M36

18. Paleostructural trends of stratigraphic sequence one in northern Great Plains M39

19. Chart showing detailed stratigraphic units of stratigraphic sequence two 
20-23. Maps showing:

20. Isopachs of stratigraphic sequence two $\mathbf{M 4 2}$

21. Paleogeography of middle part of stratigraphic sequence two (Middle Ordovician) M43

22. Paleogeography of mid-late part of stratigraphic sequence two (Late Ordovician) M44

23. Areas of known Silurian rocks (upper part of stratigraphic sequence two) M45

24. Cross section showing stratigraphic sequence two across the Transcontinental arch $\quad$ M47

25-34. Maps showing:

25. Isopachs of Winnipeg Formation and equivalent rocks $\mathbf{M 5 0}$

26. Isopachs of Black Island Sandstone Member of the Winnipeg Formation M52

27. Isopachs of Ice Box Member of the Winnipeg Formation M54

28. Isopachs of Roughlock Member of the Winnipeg Formation $\mathbf{M 5 5}$

29. Isopachs of Red River Formation-Bighom Dolomite-Whitewood Dolomite interval M56

30. Lithology of Red River Formation-Bighorn Dolomite-Whitewood Dolomite interval $\mathbf{M 5 8}$

31. Isopachs of Stony Mountain Formation and equivalent rocks $\mathbf{M 6 2}$

32. Isopachs of Interlake Formation M64

33. Paleostructural trends of stratigraphic sequence two in the northern Great Plains M66

34. Isopachs of stratigraphic sequences three, four, and five, combined $\mathbf{M 6 8}$

35. Chart showing stratigraphic units of stratigraphic sequences three, four, and five (Devonian and Mississippian) M69

36-65. Maps showing:

36. Paleogeography at beginning of stratigraphic sequence three (early Late Devonian) M71

37. Paleogeography at beginning of stratigraphic sequence four (Late Devonian or Early Mississippian) $\quad$ M72

38. Paleogeography of Kinderhookian part of stratigraphic sequence four M73

39. Paleogeography of Osagean part of stratigraphic sequence four

40. Paleogeography of Meramecian part of stratigraphic sequence four M75

41. Paleogeography of stratigraphic sequence five (Chesterian) $\quad \mathbf{M 7 6}$

42. Isopachs of stratigraphic sequence three (Devonian, undifferentiated) $\quad$ M78

43. Isopachs of stratigraphic sequence four (older Mississippian rocks) $\quad$ M83

44. Isopachs of stratigraphic sequences four and five, combined

45. Lithology of total Madison Limestone interval M86

46. Isopachs of basal clastic unit of stratigraphic sequence four

47. Isopachs of M1-M3 interval of stratigraphic sequence four

48. Lithology of M1-M3 interval of stratigraphic sequence four

49. Isopachs of $\mathbf{M} 3-\mathrm{M} 7$ interval of stratigraphic sequence four

50. Lithology of M3-M7 interval of stratigraphic sequence four

51. Isopachs of M7-M8.5 interval of stratigraphic sequence four

52. Lithology of M7-M8.5 interval of stratigraphic sequence four

53. Isopachs of M8.5-M12 interval of stratigraphic sequence four

54. Lithology of M8.5-M12 interval of stratigraphic sequence four

55. Isopachs of M12-Mc interval of stratigraphic sequence four 
56. Lithology of M12-Mc interval of stratigraphic sequence four M130

57. Paleostructural trends of stratigraphic sequence three in the northern Great Plains (Middle and Late Devonian) M137

58. Paleostructural trends of stratigraphic sequence four in the northern Great Plains (older Mississippian) M138

59. Isopachs of Big Snowy Group and equivalent rocks M141

60. Paleostructural trends of stratigraphic sequence five in the northern Great Plains (younger Mississippian) M142

61. Paleogeography following close of stratigraphic sequence five (mid-Carboniferous to mid-Triassic) $\quad$ M144

62. Feet of porosity greater than or equal to 10 percent in Red River Formation-Bighorn Dolomite part of stratigraphic sequence two M146

63. Petroleum source rocks in Rocky Mountain region M148

64. Feet of porosity greater than or equal to 10 percent in Madison Limestone intervals of stratigraphic sequence four M150

65. Feet of porosity greater than or equal to 15 percent in Madison Limestone intervals of stratigraphic sequence four $\mathbf{M 1 5 6}$ 


\title{
Cambrian through Mississippian Rocks of the Powder River Basin, Wyoming, Montana, and Adjacent Areas
}

\author{
By David L. Macke
}

\begin{abstract}
Cambrian through Mississippian rocks in the Powder River Basin represent five depositional sequences that reflect both the biological evolution and the tectonic development of western North America. The first depositional sequence spans the Middle Cambrian through Early Ordovician; the second, the Middle Ordovician through Silurian; the third, the Devonian; the fourth, the older Mississippian (Kinderhookian through older Meramecian); and the fifth, the younger Mississippian (younger Meramecian through Chesterian). The first depositional basin was marginal to the western (Cordilleran) continental margin; the second depositional basin was open to the southern (Ouachita) continental margin through the Nebraska sag and possibly through the Colorado extension of the Oklahoma Basin (following the Anadarko Basin-Wet Mountains trend); and the depositional basin for the third through fifth sequences was open to the northwest through central Montana and possibly to the north through Canada.

Cambrian through Mississippian carbonate rocks reflect biological evolution. Middle Cambrian carbonate rocks are mainly micrite trapped by microbial mats, whereas Upper Cambrian to Lower Ordovician carbonate rocks reflect the increasing importance of skeletal organic remains. In the Middle Cambrian and Early Ordovician, organisms were not well adapted to environments of the interior basins, and reefs developed only along continental margins. In the Middle Ordovician to Late Devonian, reef-building organisms formed ecological assemblages and secreted calcium carbonate in their tissues at a more rapid rate than did earlier forms. The reef ecosystem collapsed in Late Devonian time, and Mississippian bioherms are primarily Waulsortian mud mounds limited to the deep, clear waters of the continental margins and deep basins.
\end{abstract}

Structures inherited from Precambrian continental accretion and rifting controlled Middle Cambrian through Early Ordovician sedimentation patterns. A secondary structural control was initial rifting of the Ouachita margin. Middle Ordovician through Early Devonian sedimentation was affected by uplift of the western margin of the craton, probably by subduction-related processes, and by rifting and subsidence of the Ouachita margin. The Transcontinental arch and much of the northern Great Plains were uplifted and eroded as subduction along the Ouachita margin began in the Early or Middle Silurian. Renewed marine transgression through the Williston Basin onto the Wyoming shelf in the Middle Devonian initiated Late Devonian through Mississippian deposition on the Wyoming shelf. Tectonic activity along the western cratonic margin during the Middle Devonian through Mississippian may have been dominated by (1) the Late Devonian Antler orogeny, (2) Middle Devonian thermal uplift, (3) strikeslip tectonics, or (4) a combination of these.

\section{INTRODUCTION}

The Powder River Basin is a Laramide (Late Cretaceous-Eocene), Green River-type, broken-foreland basin (Chapin and Cather, 1983) in northeastern Wyoming and southeastern Montana (fig. 1). The basin is about $220 \mathrm{mi}$ $(354 \mathrm{~km})$ from north to south, is generally less than $95 \mathrm{mi}$ $(153 \mathrm{~km})$ from east to west, and underlies an area of about $11,500 \mathrm{mi}^{2}\left(29,785 \mathrm{~km}^{2}\right)$. The basin axis trends northsouth several kilometers west of the basin midline, and structural relief within the basin is greater than $25,000 \mathrm{ft}$ $(7,620 \mathrm{~m})$ (Blackstone, 1981). Strata at the surface generally dip less than $3^{\circ}$ in most of the basin, but dips steepen to between $30^{\circ}$ and almost vertical or overturned on the southwestern and western flanks (Blackstone, 1981). The basin is bounded by the Black Hills and the Miles City arch on the east and northeast, by the Bighorn Mountains on the west, and by the Casper arch, the Laramie Mountains, and the Hartville uplift on the south (Blackstone, 1981; Gries, 1983; Peterson, 1984) (fig. 1). Thrust and reverse faults on the eastern flank of the Bighorn Mountains are displaced about $4,100 \mathrm{ft}(1,250 \mathrm{~m}$ (Blackstone, 


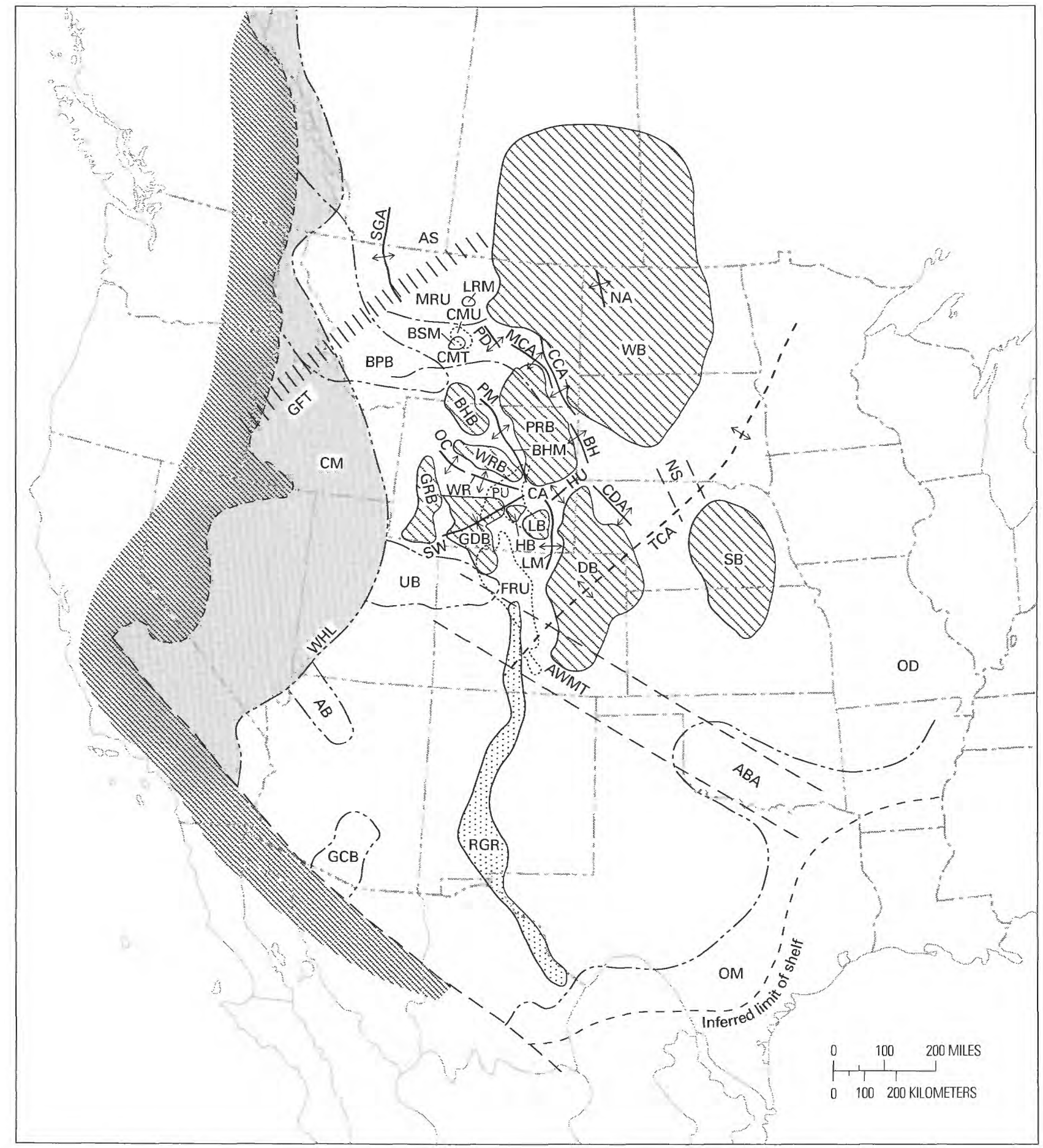




\section{EXPLANATION}

Area of thinned continental crust

Crust added during post-Paleozoic accretion and affected by Tertiary extension

Sedimentary rocks of Cenozoic rift

Laramide basin

Outline of Paleozoic uplift

Precambrian rift boundary

- - - Lineament

- - - Precambrian basement uplift of Transcontinental Arch

$\uparrow$ Anticline

* Syncline

|||||||| Great Falls Tectonic Zone

\section{_ _ Boundary of Central Montana Trough}

Figure 1. Index map showing location of the Powder River Basin and adjacent tectonic features. Compiled from Dickinson (1981), Harrison and others (1974), Stewart (1976), Stewart and Suczek (1977), and others. AB, Apache Basin; ABA, Anadarko Basin; AS, Alberta shelf; AWMT, Anadarko-Wet Mountains trend (Colorado extension of Oklahoma Basin); BH, Black Hills; BHB, Big Horn Basin; BPB, Belt-Purcell Basin; BHM, Bighorn Mountains; BSM, Big Snowy Mountains; CA, Casper arch; CCA, Cedar Creek anticline; CDA, Chadron arch; CM, Cordilleran miogeocline; CMT, Central Montana trough (Big Snowy trough); CMU, Central Montana uplift; DB, Denver Basin; FRU, ancestral Rocky Mountain uplift; GCB, Grand Canyon Basin; GDB, Great Divide Basin; GRB, Green River Basin; HB, Hanna Basin; HU, Hartville uplift; LB, Laramie Basin; LM, Laramie Mountains; LRM, Little Rocky Mountains; MCA, Miles City arch; MRU, Milk River uplift; NA, Nesson anticline; NS, Nebraska sag; PU, Pathfinder uplift; OC, Owl Creek Mountains; OD, Ozark Dome; OM, Ouachita miogeocline (Ouachita margin); PD, Porcupine Dome; PM, Pryor Mountains; PRB, Powder River Basin; RGR, Rio Grande rift; SB, Salina Basin; SGA, Sweetgrass arch; SW, Sweetwater trough; UB, Uinta Basin (Uinta trough); WB, Williston Basin; WHL, Wasatch hinge line; WRB, Wind River Basin; WR, Wind River Mountains.

1981). Faults, folds, and linear features within the basin are shown on a map compiled by Cooley (1986).

The structures presently surrounding the Powder River Basin did not influence early Paleozoic sedimentation except possibly as ancestral, regional tectonic features (Wyoming Geological Association Technical Studies Committee, 1965; Brown and others, 1984). Almost all of the present structural configuration of the basin formed during the Late Cretaceous and early Tertiary Laramide orogeny (Blackstone, 1949). Major deformation of the basin area began in the Paleocene and ended before deposition of the Oligocene White River Formation. Middle Cambrian through Oligocene rocks make up the Phanerozoic section within the basin area and include a thick sequence of Upper Cretaceous through lower Paleocene rocks deposited during the Cordilleran orogeny before basin formation in late Paleocene or early Eocene time. Thus, the Powder River Basin as a structural and depositional entity did not exist during deposition of the lower Paleozoic strata analyzed in this study. Upper Paleozoic facies and thickness trends, however, show a northwestsoutheast depositional axis, somewhat east of the modern basin axis, in northeastern Wyoming. Bates (1955) named this depositional trend, which extends northward from the Alliance Basin, the Lusk embayment.

\section{Scope of Study}

The present study examined the depositional framework of lower Paleozoic rocks in the Powder River Basin and the surrounding region as shown in figure 1. Figure 3 (later) shows both the area included in the stratigraphic cross sections (pls. 1, 2) and the area of the detailed isopach and lithofacies maps included in the text. The study area is much larger than the area of the present-day Powder River Basin in order to include ancient tectonic features that influenced sedimentation. Much of the information herein is from localities outside the present confines of the Powder River Basin because the stratigraphic units have wide regional distribution. Detailed descriptions and lithofacies maps have been published previously for the northern Great Plains region including the Powder River Basin area (Wyoming Geological Association Technical Studies Committee, 1965; Mallory, 1972; Peterson, 1984; Peterson and MacCary, 1987).

\section{Stratigraphic Sequences}

Lower Paleozoic rocks in the Powder River Basin and adjacent areas included in this study range in age from Middle Cambrian (Albertan) through Late Mississippian. I divided these rocks into five stratigraphic sequences (fig. 2): (1) Middle Cambrian through Lower Ordovician, (2) Middle Ordovician through Silurian, (3) Devonian, (4) older Mississippian (Kinderhookian through lower Meramecian), and (5) younger Mississippian (upper 


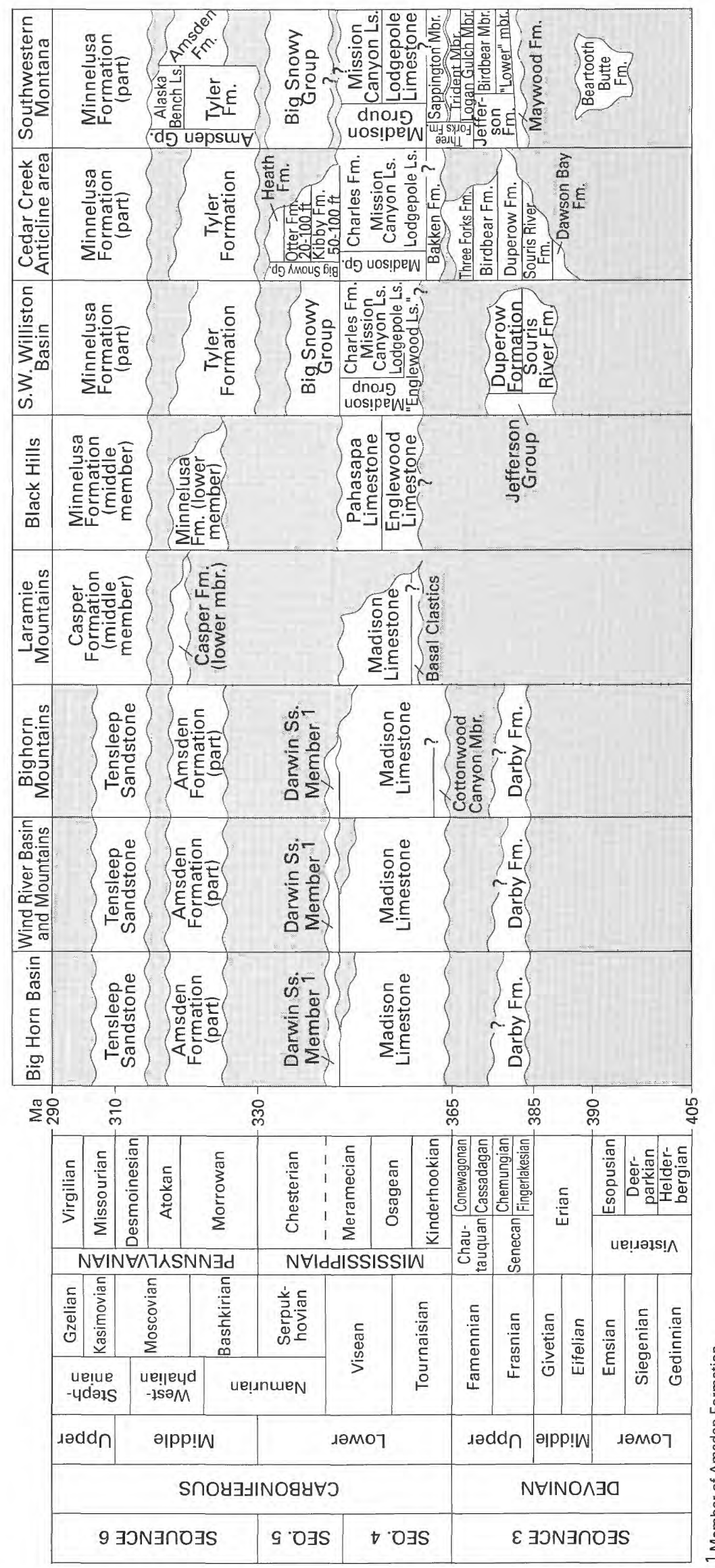




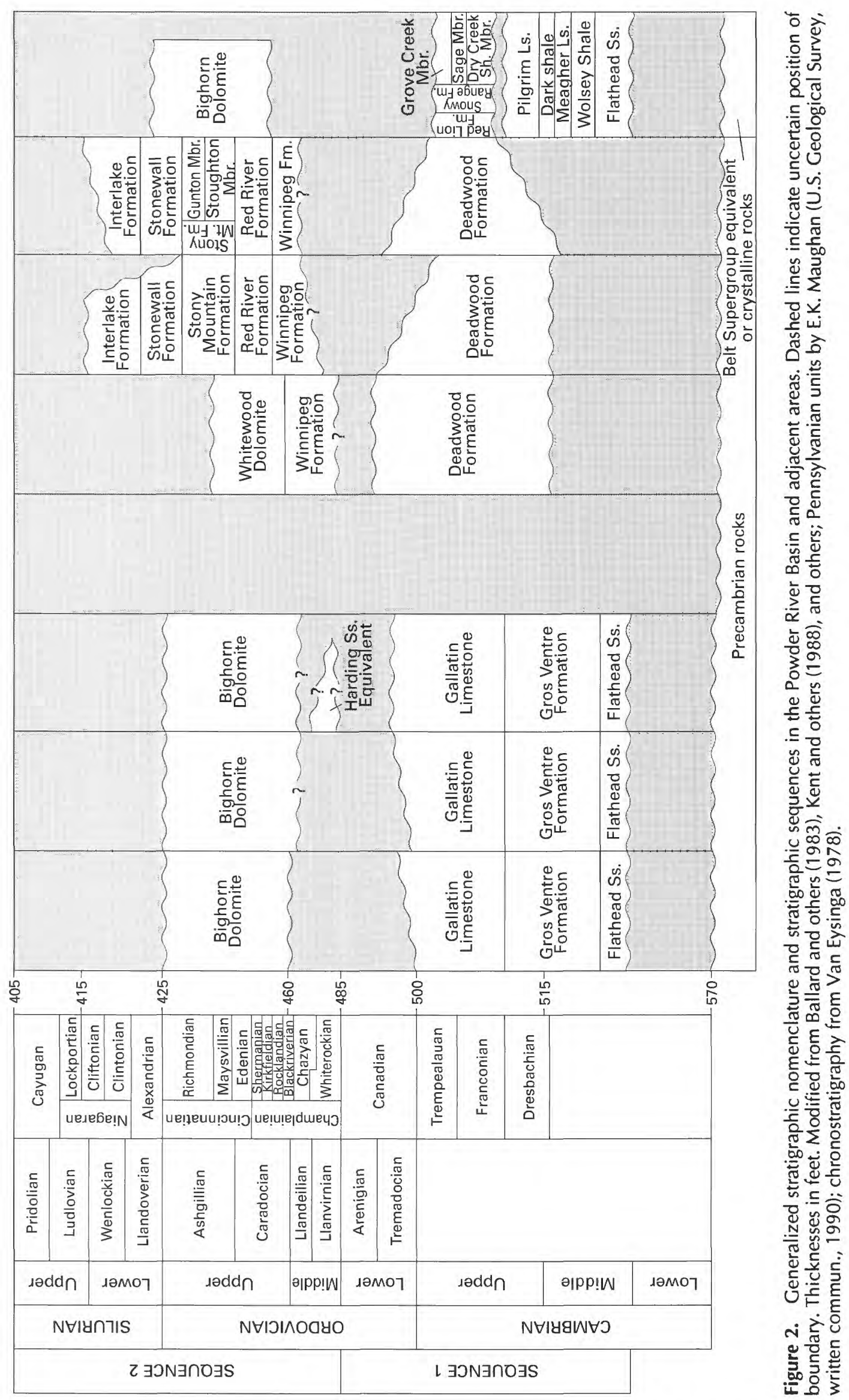


Meramecian and Chesterian). Major unconformities inferred to represent regional tectonic changes are present between all these sequences except between the older and younger Mississippian. The unconformities shown on the cross sections (pls. 1, 2) are those of greatest regional significance (fig. 2). Stratigraphic sequences emphasize the effects of contemporaneous tectonic activity, especially along the western and southern cratonal margins (the Cordilleran and Ouachita margins), whereas conventional stratigraphic analysis using formation boundaries tends to obscure relationships between tectonic activity and sedimentation. Stratigraphic sequences three, four, and five were deposited within similar tectonic settings and are discussed together. Rocks of Silurian through Middle Devonian age are totally absent in the Powder River Basin area except for isolated remnants of the Interlake Formation (Late Ordovician and Silurian age according to Sandberg and Mapel, 1967, and Peterson and MacCary, 1987; Silurian age according to Ballard and others, 1983) and the Lower Devonian Beartooth Butte Formation (Dorf, 1934a, b; Blackstone and McGrew, 1954; Sandberg and Mapel, 1967).

Unconformities are present within the Ordovician and Devonian sections, and diastems may be present within the Cambrian and the older Mississippian (Kinderhookian through lower Meramecian) sections. Outcrops in the Bighorn Mountains and elsewhere suggest that parts of the older Mississippian section were epeirogenically disturbed during late phases of the Antler orogeny (E.K. Maughan, oral commun., 1988). Rocks of the stratigraphic sequences used in this report, however, were deposited in distinctive tectonic settings, and the sequences are generally made up of conformable lithostratigraphic units.

Rocks of Meramecian and Chesterian (Late Mississippian) age are locally present within the basin area as a sandstone-mudstone sequence, the Big Snowy Group, and as the Darwin Sandstone Member of the Amsden Formation. The Darwin has been assigned by various workers as the basal member of the Amsden Formation and has been dated as Meramecian and Chesterian to as young as Desmoinesian(?) in age. In the present report, the Darwin is considered Meramecian and Chesterian in age because it interfingers with the Meramecian and Chesterian Kibbey Sandstone (Sando and others, 1985), a relationship that can be observed at Miller Butte in Jackson Hole, northwestern Wyoming (SE1/4 $\mathrm{SE}^{1 / 4}$ sec. 23 , T. 41 N., R. 116 W., Teton Co., Wyo.) (E.K. Maughan, 1991, oral commun.), and in adjacent areas of southwestern Montana. The Darwin is also considered to be conformable with and locally transitional into the underlying Madison Limestone. The Darwin is considered to be separated from the overlying Horseshoe Shale Member of the Amsden Formation by a latest Mississippian or Early Pennsylvanian regional unconformity (E.K. Maughan, written commun., Oct. 3, 1989). The Darwin, therefore, is included within stratigraphic sequence five (younger Mississippian rocks). The Darwin is present in the basin area primarily as isolated outcrops along the flanks of the Bighorn Mountains and is generally missing east of the Bighorn Mountains due to erosion or nondeposition, and it is not shown on cross sections of the present report. The age of the Darwin, however, is critical to dating the top of the Mississippian sequence within the basin area.

\section{Subsurface Cross Sections}

The Powder River Basin is one of the most actively explored Rocky Mountain basins for hydrocarbons, yet lower Paleozoic (Cambrian through Mississippian) rocks of this area remain little studied. As a part of a program studying the evolution of this sedimentary basin, approximately $2,000 \mathrm{mi}(3,218 \mathrm{~km})$ of cross sections, based on more than 50 combined geophysical and lithologic logs, were constructed in an area of about $40,000 \mathrm{mi}^{2}(103,600$ $\mathrm{km}^{2}$ ) (figs. 3, 4, pls. 1, 2).

The five cross sections in this report (fig. 3) are from 240 to $430 \mathrm{mi}(406-692 \mathrm{~km})$ in length $(75-300 \mathrm{mi}$ $(121-483 \mathrm{~km})$ direct distance). Cross sections are based on 53 boreholes in Wyoming (27), Montana (19), and Nebraska (7). Wells are from 6 to $58 \mathrm{mi}(9.6-93 \mathrm{~km})$ apart. Twenty-five of the wells reach the Precambrian rocks. Correlations were made using gamma-ray and neutron logs combined with lithologic data from American Stratigraphic Company (AMSTRAT) logs wherever possible and spontaneous potential and resistivity logs where gamma-ray or neutron logs were not available. Only the AMSTRAT sample logs were available for several wells, and if sample logs were not available only the wire-line logs were used.

The lines of section extend beyond the Powder River Basin and include boreholes from the greater Green River Basin, the Denver Basin, the Chadron arch, the Williston Basin, the Central Montana uplift, the Big Horn Basin, and the Wind River Basin (fig. 1). The cross sections on plates 1 and 2 show physiographic boundaries.

Line $A-A^{\prime}$ in Wyoming and Nebraska follows the northern flank of the Denver Basin, south of the Powder River Basin. Line $B-B^{\prime}$ extends from the Casper arch at the eastern end of the Wind River Basin to the west flank of the Chadron arch in eastern Nebraska. Line $C-C^{\prime}-C^{\prime \prime}$ extends from the greater Green River Basin (the Washakie and Shirley Basins in Carbon County, Wyoming), across the Casper arch, and along the western flank of the Powder River Basin northward to the Central Montana uplift. Line $D-D^{\prime}-D^{\prime \prime}$ extends northward from the Denver Basin in northeastern Nebraska, to the eastern part of the Hartville uplift, then west of the Black Hills and into the western Williston Basin in eastern Montana. Line $E-E^{\prime}-E^{\prime \prime}$ 


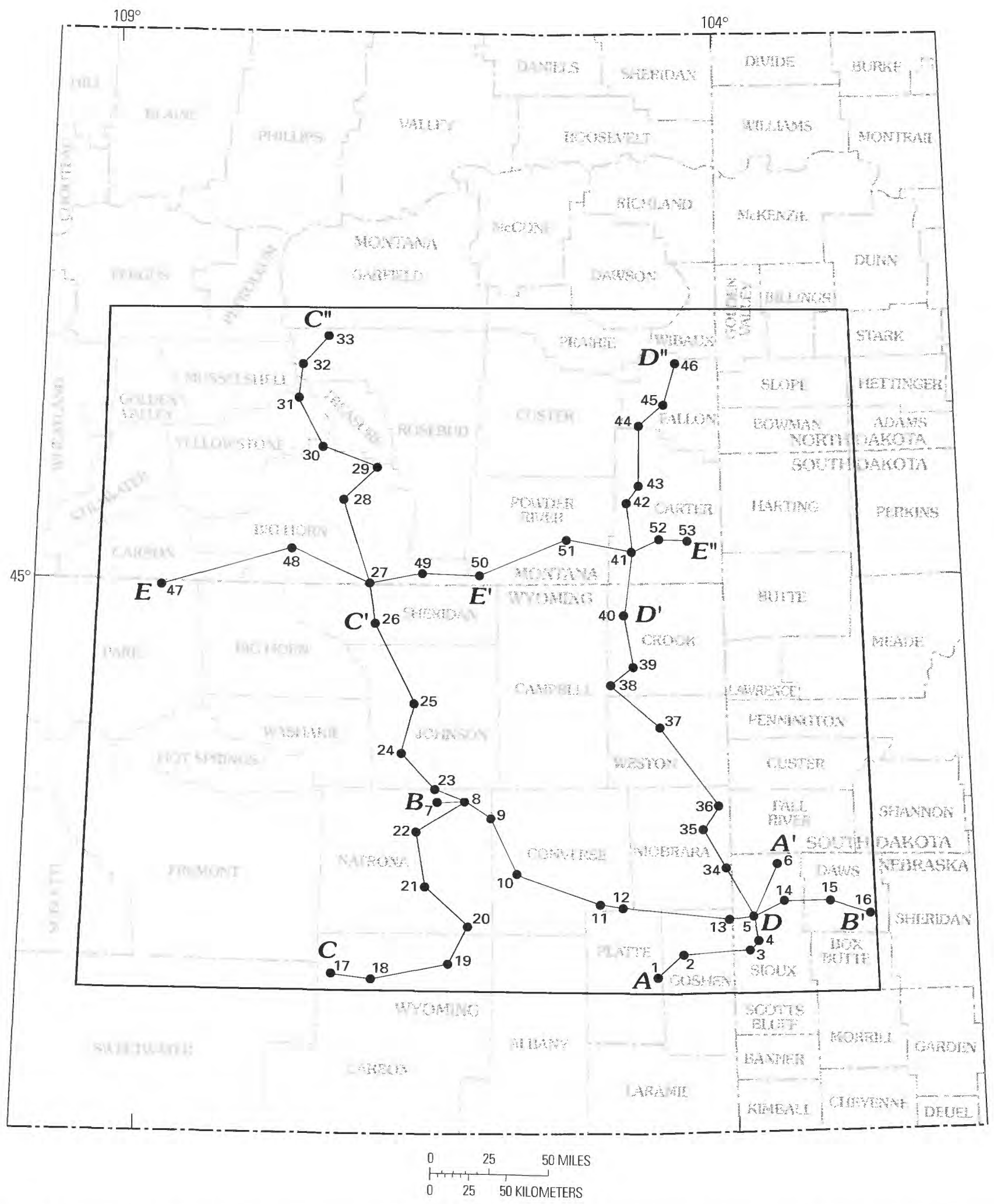

Figure 3. Location of lines of sections shown on plates 1 and 2 and figure 4 and area of isopach and facies maps in following figures (outlined). 
extends eastward from the northern Big Horn Basin in Big Horn County, Wyoming, along the Wyoming-Montana State line to the western edge of the Williston Basin in southeastern Montana.

The U.S. Geological Survey Northern Great Plains well data base, compiled under the direction of James A. Peterson for a study of aquifers within the lower Paleozoic (Downey, 1982; Peterson, 1984), provided the basis for the cross sections and stratigraphic correlations of the present report.

\section{Paleobiological Changes}

The Cambrian through Mississippian Systems represent almost half of Phanerozoic time, and the evolution of marine life during this time played a crucial role in the development of the rock record. Evolutionary changes in carbonate-producing organisms and climatic changes associated with continental drift played roles almost as important as that of tectonics in the evolution of the rock record in Cambrian through Mississippian depositional basins. Wilson (1975), James (1983), and Scholle and others (1983) discussed the relations between carbonate depositional environments and biotic changes.

\section{Paleotectonic Setting}

During early Paleozoic time, the Powder River Basin did not exist as a structural and depositional entity; the area was part of other regional features such as the southwestern margin of the Williston Basin or part of the Wyoming shelf. The Cambrian through Mississippian depositional sequences of the area (fig. 2) reflect eustatic sea-level fluctuations, biological changes, subsidence of intracratonic basins, regional activation of linear structural elements, and vertical adjustments of blocks of the Precambrian basement. Major paleostructural elements such as the Transcontinental arch, Alberta shelf, Canadian Shield, Williston Basin, and Central Montana trough affected the accumulation of sediments for long intervals of geologic time, whereas smaller elements such as faults, anticlines, and lineaments intermittently controlled sediment deposition and erosion (Brown and others, 1984). The Powder River Basin area was well removed from the continental margins during the early Paleozoic (fig. 1), but activity along the margins, whether compressional, extensional, or lateral, drove structural development within the craton and shaped the sedimentary record within the basin.

Upwarping of the craton formed most of the important Paleozoic tectonic elements. Broad stable shelves, which were subject only to sporadic minor downwarping, occupied most of the craton. On the western border, a narrow

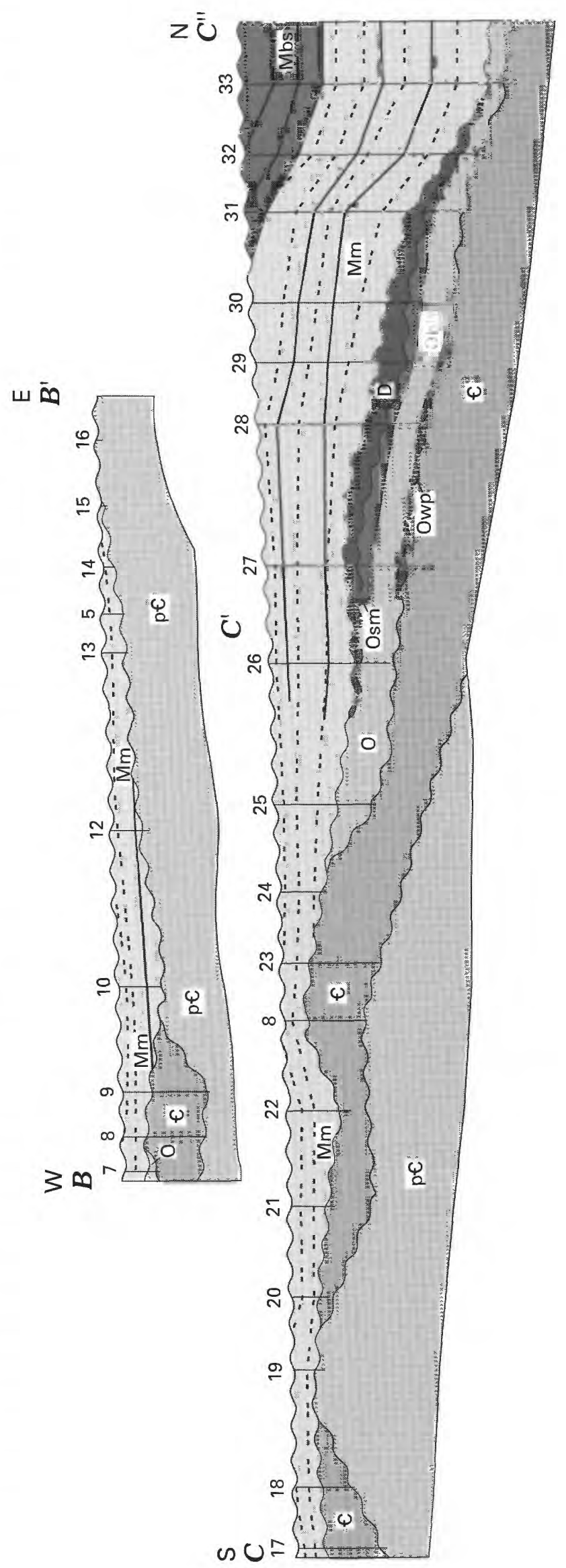




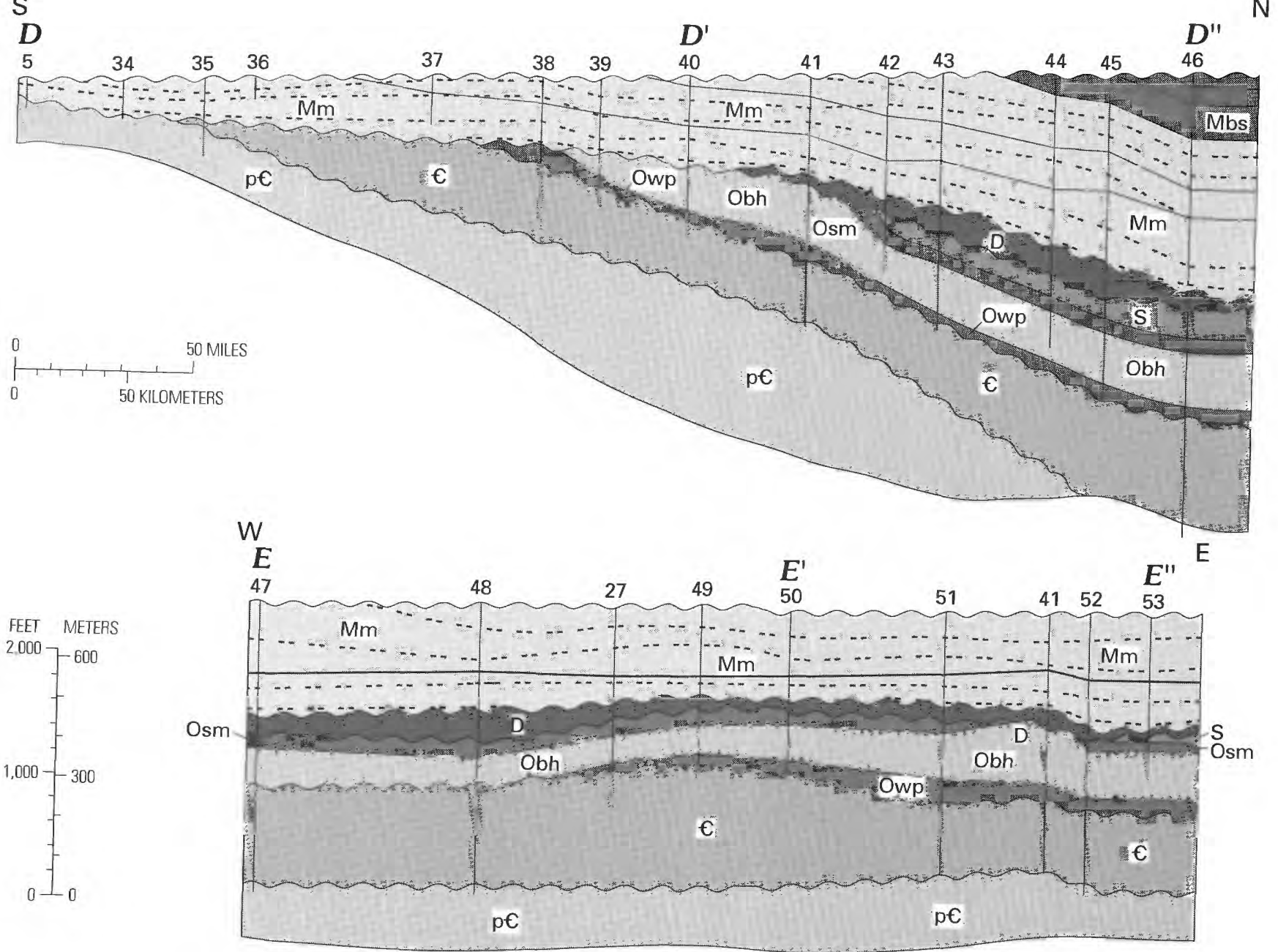

Figure 4 (above and facing column). Cross sections of lower Paleozoic rocks, Powder River Basin area. Wavy lines are major unconformities. Solid lines are formational boundaries. Numbers refer to borehole localities as shown on plates 1 and 2 and figure 5 . Dotted lines are marker horizons within the Madison Limestone (Group) discussed in text. $p €$, Precambrian rocks: $€$, Cambrian rocks; $O$, Ordov-

linear unstable shelf merged into several tectonically negative miogeoclinal basins separated by a weak positive uplift of the southern Alberta shelf to the north (Montania of Lochman-Balk, 1960). Crustal features inherited from Precambrian tectonic activity also strongly affected early Paleozoic deposition in the Powder River Basin area. The Powder River Basin area occupies the eastern margin of the Wyoming shelf and is underlain by the Wyoming Archean province and old mobile belts that separate this province from surrounding terranes (fig. 5) (Tonnsen, 1986). Precambrian terranes surrounding the Wyoming province include the central Montana province to the north, the Superior province to the east, and the Colorado province to the south. Different responses of the dissimilar provinces and the intervening mobile belts to Paleozoic ician rocks, undifferentiated; Owp, Middle Ordovician Winnipeg Formation; Orr, Middle and Upper Ordovician Red River Formation; Ob, Middle and Upper Ordovician Bighorn Dolomite and equivalent rocks; Osm, Upper Ordovician Stony Mountain Formation; S, Silurian rocks; D, Devonian rocks; Mm, Mississippian Madison Limestone Group; Mbs, Upper Mississippian Big Snowy Group.

tectonic activity impart many of the local variations in the stratigraphic successions. The crust of the Wyoming Archean province may be as much as $32,810 \mathrm{ft}(10,000 \mathrm{~m})$ thinner than the surrounding Proterozoic basement to the north and south, and these thickness variations may be one reason why the basement provinces responded differently to tectonic movement (Allmendinger and others, 1982; Tonnsen, 1986).

The Transcontinental arch is south and east of the Powder River Basin area. The arch persisted as a northeast-trending tectonic element during the early Paleozoic and may have served as a source area throughout much of the Paleozoic Era. Most of the record of transgression onto the arch has been removed by erosion along the flank of the arch. The Transcontinental arch probably represents 
a suture zone between crustal blocks at least 2.5 b.y. old to the north and blocks 1.7-1.9 b.y. old to the south (Nelson and DePaolo, 1985; Bennett and DePaolo, 1987). A 1.75-Ga potassium-argon age within the Slate Creek terrane, just north of the Wyoming shear zone, records suturing (Holden and Fleckenstine, 1980). Erosional thinning of the Wyoming shelf before docking of the Transcontinental arch terrane (the southern Wyoming province of Tonnsen, 1986) may be responsible for the differences in crustal thickness between the two terranes, although the Archean island arc terrane may have been thinner than the Proterozoic terrane.

The shear zone (suture?) separating the Wyoming Archean province from the Proterozoic volcanic arc succession (Houston, 1978; Hills and Houston, 1979; Condie and Shadel, 1983; Nelson and DePaolo, 1985; Tonnsen, 1986; Bennett and DePaolo, 1987) (fig. 5) of the Transcontinental arch (the Southern Wyoming province of Tonnsen, 1986) (fig. 5) apparently controlled the positions of the Permian Sweetwater trough (named by Mallory, 1975 , p. 266) and an Early Cambrian basin in roughly the same position that I will refer to as the proto-Sweetwater trough. In western and central North Dakota, a possible earlier mobile belt between the Wyoming Archean province and the Superior Precambrian province to the northeast (Cavanaugh and Seyfert, 1977; Lewry and Sibbald, 1980) also may have affected deposition as a control on the position of the Williston Basin. Basement controls on sedimentation farther to the east are less certain, but uplift, downwarping, and onlap onto the Precambrian Superior province also shaped depositional patterns on the Wyoming shelf.

Farther to the south, the Anadarko-Wet Mountains trough (the Colorado trough of Mallory, 1975, p. 266) extends from the Oquirrh Basin eastward into the Rocky Mountain region and is coincident with a west-northwesttrending Middle Proterozoic (1,600-1,200 Ma) and Cambrian and Ordovician dike swarm that can be traced eastward from eastern Utah to the Anadarko Basin in Oklahoma (Larson and others, 1985). In Colorado, Cambrian intrusive rocks range in age from 570 to $495 \mathrm{Ma}$; in the Anadarko Basin, intrusive rocks are dated most reliably as older than $525 \mathrm{Ma}$. The Anadarko-Wet Mountains trend may be the failed arm of a triple junction (Hoffman and others, 1974), a rift system related to the Proterozoic Midcontinent rift, or a precursor to the northern Cenozoic Rio Grande rift (Gilbert, 1983; Larson and others, 1985).

To the north, the Central Montana trough (Lewis and Clark lane of Maughan and Perry, 1986) trends east-southeastward across central Montana into the Miles City arch and the northern Powder River Basin. The trough was a major structurally active region near the Powder River Basin before the onset of the late Cordilleran (Laramide) orogeny in the Paleogene. Thin Cambrian sections within the trough suggest that uplift began as early as Cambrian time. Structural elements within the trough have been intermittently active since at least Ordovician time (Brown and others, 1984). The Central Montana uplift, within the Central Montana trough, formed during the Devonian (Alpha, 1958; Norwood, 1965; Peterson, 1966, 1984; Sandberg and Mapel, 1967; Lochman-Balk, 1972; Peterson and others, 1987).

Phanerozoic subsidence within the Central Montana trough began during Mississippian time but took place mainly during Early Pennsylvanian deposition of the Tyler Formation (Maughan, 1984; Maughan and Perry, 1986). During Permian time, the northern part of the Powder River Basin and the Miles City arch in southeastern Montana lay along the southeastern flank of the Milk River uplift, which extended across most of Montana. Upper Paleozoic rocks (Pennsylvanian and Permian) are absent from the Milk River uplift and are somewhat thinner on the Miles City arch than they are eastward in the Williston Basin and southward in the Powder River Basin. This thinning suggests at least minor late Paleozoic uplift along the eastern Central Montana trough.

In central Montana, the Belt-Purcell Basin separates a Precambrian volcanic arc complex from supracrustal rocks of the central Montana province (Tonnsen, 1986). The Great Falls tectonic zone (O'Neil and Lopez, 1985) forms the southern edge of the Belt-Purcell Basin and borders the Wyoming shelf. It is also a zone of recurrent movement along the southwestern projection of the boundary between the Superior and Churchill Precambrian provinces of the Canadian Shield.

To the west, the Wyoming province is bordered by the Cordilleran miogeocline, which extended from the Wasatch hinge line to the western edge of the autochthonous craton. The miogeocline began as a passive margin (Dickinson, 1977) following rifting of the western margin between 600 and $550 \mathrm{Ma}$ ago (Larson and others, 1985) when a rift almost $1,250 \mathrm{mi}(2,011 \mathrm{~km})$ long formed and produced an open ocean to the west (Dickinson, 1974; Templemen-Kluit, 1979; Bond and others, 1983). Southwest of the present-day Powder River Basin, a thick package of rocks interpreted as deltaic deposits that formed during a pause in the late Precambrian rifting of the western cratonic margin underlies the Uinta arch in the position of the earlier Uinta Basin (Winston, 1988). The sequence of sandstone, shale, siltstone, and carbonate rocks is similar to that within the older Belt-Purcell Basin in central Montana (Peterson, 1984, 1985) and has been interpreted as the result of deposition in either a marine or a mixed lacustrine and brackish setting (Harrison, 1972; Peterson, 1985). The Belt-Purcell, Uinta, Coeur D'Alene, Wernecke-McKenzie Mountain, Apache, and Grand Canyon Basins influenced deposition throughout at least Paleozoic time and perhaps part of Mesozoic time (Harrison and others, 1974; Peterson, 1985). These features have 


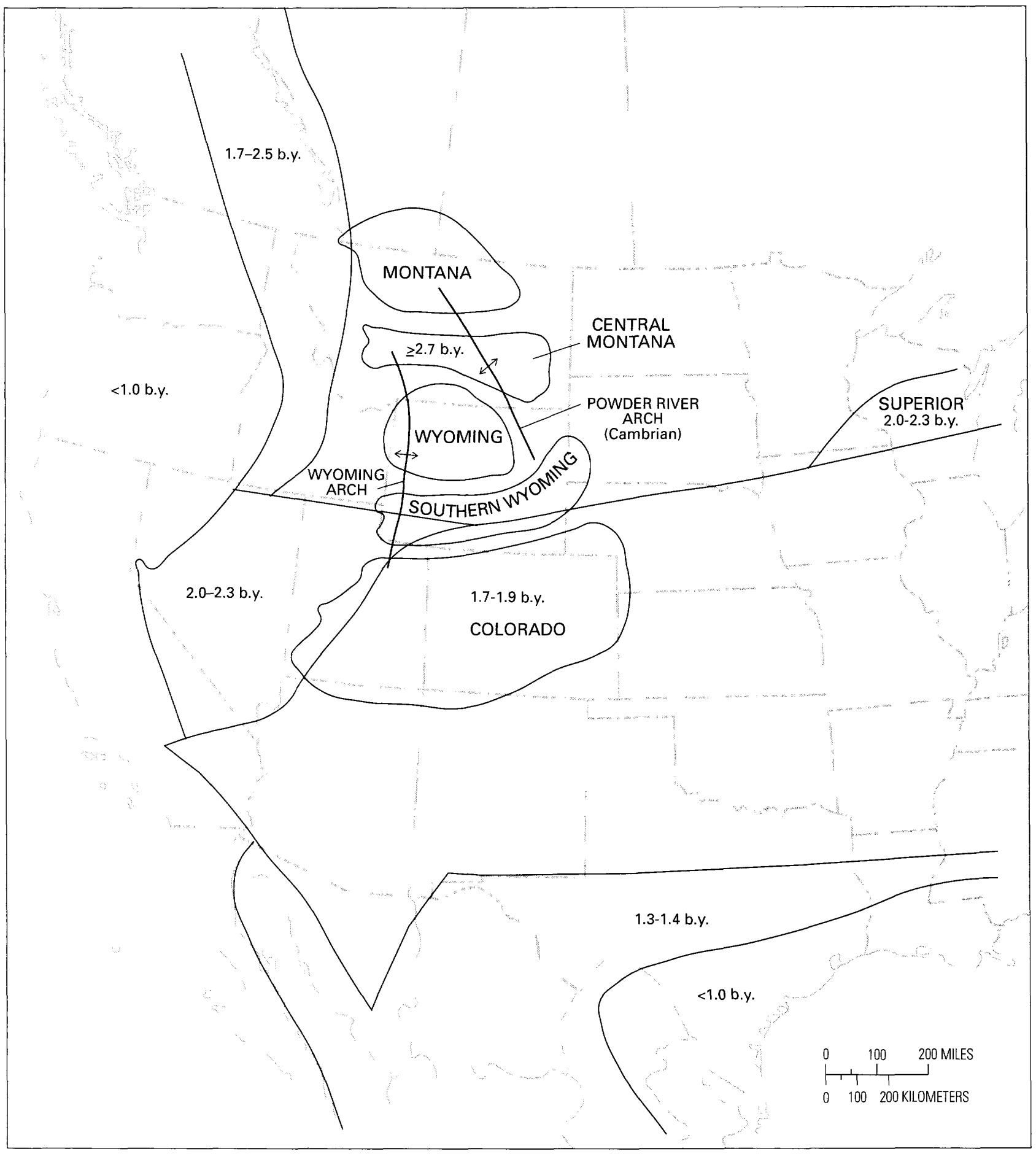

Figure 5. Crustal formation-age provinces based on neodymium isotopic ages. Labeled provinces are those referred to in the text by name. Modified from Nelson and DePaolo (1985) and Tonnsen (1986).

been interpreted as either epicratonic troughs (Dickinson, 1981) or aulacogens (Howell and Schermer, 1983).

Rifting affected the crust as far east as the Powder River Basin and broke the continental margin into a series of block-faulted sub-basins and uplifts, probably along still older structures. Erosion prior to or accompanying rifting may have removed Proterozoic sedimentary rocks from most of the northern Great Plains; "Eocambrian" rocks of the eastern Black Hills are a remnant of this sequence (Peterson, 1984). Rifting of the western margin corresponds roughly in time with the Avalonian-Cadomian orogenic cycle $(670-550 \mathrm{Ma})$ along the eastern margin of 
the United States (Murphy and Nance, 1989). The miogeocline contains the most complete record of early Paleozoic sedimentation along the western margin of the craton. The miogeocline and the Williston Basin were the only sites of deposition during times of regression.

A broad area in western Wyoming, apparently a southern extension of the Peace River arch and the Alberta shelf, and roughly centered about the Wasatch hinge line, was uplifted intermittently from Middle Ordovician through at least Early Mississippian time. I refer to this area as the Wyoming arch (fig. 5).

The Williston Basin is north-northeast of the presentday Powder River Basin in eastern Montana, North Dakota, and northern South Dakota and extends northward into Saskatchewan and Manitoba. The Black Hills and the Miles City arch separate the northern part of the Powder River Basin from the southern Williston Basin. The Miles City arch was a broad, gentle anticlinal structure during most of the Phanerozoic. Throughout most of the early Paleozoic, the area of the Powder River Basin was structurally part of the Williston Basin and was within a broad, almost featureless continental shelf, commonly called the Wyoming shelf (Eardley, 1962, p. 58).

The Williston Basin may have begun to form as early as the Late Cambrian or Early Ordovician (LeFever and others, 1987; Peterson and MacCary, 1987) and continued to subside intermittently through the Jurassic (Kent, 1987). Tenney (1966) and Peterson (1978, 1980a, 1984) concluded that the Black Hills and its southern extension, the Chadron arch, grew during the late Paleozoic. Maughan and Roberts (1967), however, suggested that the Black Hills was probably a structural feature that had only minor relief during late Paleozoic time. Peterson and MacCary (1987) suggested that the Black Hills-Chadron arch structural trend may have influenced the distribution of Mississippian and perhaps earlier Paleozoic sedimentary facies. The present study suggests some structural influence at least as early as the Ordovician. Brown (1978) showed some evidence for Cambrian, Devonian, and Mississippian paleostructural movement on the Miles City arch. From its inception, the Williston Basin was the major structural feature determining the depositional patterns within the northern Great Plains region, including the Powder River Basin area. The Williston Basin contains the most complete record of early Paleozoic sedimentation between the miogeocline and the Transcontinental arch.

The persistent subsidence of the Williston Basin is enigmatic. The Williston Basin began to subside as an intracratonic sag no later than late Tremadocian (early Early Ordovician) and possibly as early as Late Cambrian time (LeFever and others, 1987) and continued to subside through Jurassic time, seemingly little influenced by tectonic interactions along the distant continental margins. By earliest Early Ordovician time, the Williston Basin exerted a strong influence on the Powder River Basin area (Kent, 1964). Many explanations have been offered for the persistence of Williston Basin subsidence; in one of the most recent, Ahern and Mrkvicka (1984) modeled the basin as resulting from thermal contraction of the lithosphere.

The southern margin of the craton, the Ouachita margin, also played a role in controlling early Paleozoic deposition in the Powder River Basin area. Late Cambrian and Early Ordovician rifting created a passive margin along the southern margin of the continent. Doming prior to rifting and thermal subsidence following rifting probably affected areas as far north as the present-day Powder River Basin. Wrench faulting associated with subduction along the Ouachita margin probably affected sedimentation in at least Mississippian time, and collision along the margin brought early Paleozoic sedimentation to a close in Late Mississippian or Early Pennsylvanian time (Kluth and Coney, 1981; Kluth, 1986). Pre-Late Devonian and Early Pennsylvanian to Permian erosion has removed most of the sedimentary rocks from the Transcontinental arch and destroyed much of the evidence linking events of the Ouachita margin to the Powder River Basin area.

\section{STRATIGRAPHIC SEQUENCE ONE- MIDDLE CAMBRIAN THROUGH LOWER ORDOVICIAN ROCKS}

The oldest stratigraphic sequence in the Powder River Basin area includes rocks of Middle Cambrian through Early Ordovician age (figs. 6, 7). Deposition of this sequence in the Powder River Basin area began with an initial Middle Cambrian transgression and ended with an Early Ordovician regression (Lochman-Balk, 1960). The Cambrian-Ordovician boundary is conformable near the top of the sequence in the central and northern Bighorn Mountains, in the northern Black Hills, and in the subsurface farther north (Lochman-Balk and Wilson, 1967), although erosion has locally removed the youngest beds of the sequence.

\section{Cambrian through Early Ordovician Regional Tectonics}

Stratigraphic sequence one represents deposition on a broad shelf that formed during late Precambrian rifting of the western continental margin. A carbonate rim developed within the Cordilleran miogeocline on the west (Aitken, 1968, 1978, 1981a, b), and by the end of the Early Ordovician the continental shelf extended eastward into the upper Mississippi Valley (Lochman-Balk, 1972) (figs. 8, 9).

Thermal subsidence of the western margin of the continent directly controlled deposition of the Middle Cambrian 


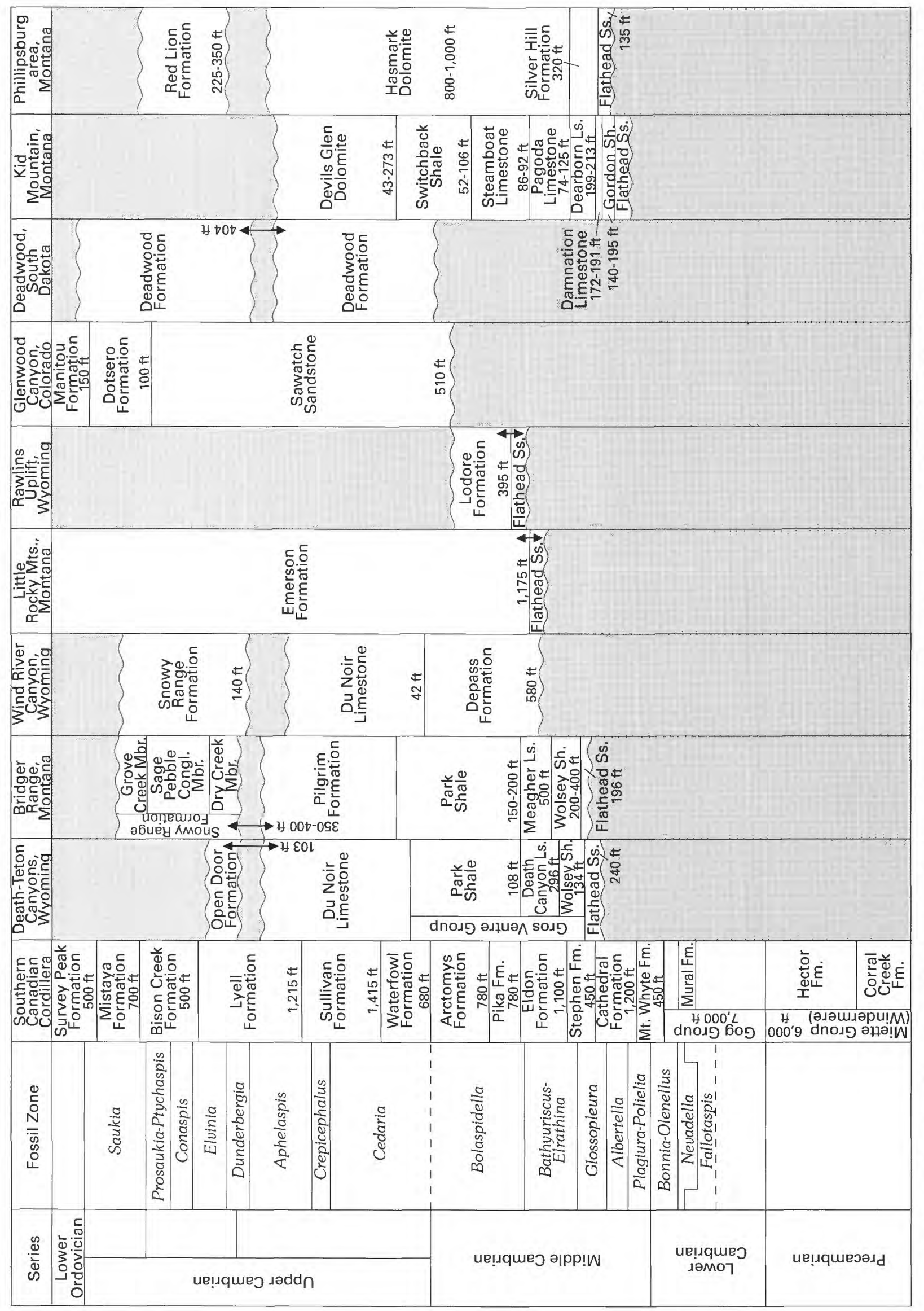

兹

c हैं. บू ํㅓㅇ $=0$ 든 政这 产웜 我 $E$ 은 吾 5

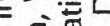

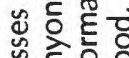
这 论 든 원 ह 든 ऽั 응 응 ○ัญ 离定 월ㄷํㅇํㄹ

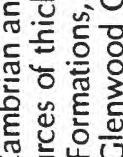
记 棺言 ธิ㇒士 응ํㅡㄴ 는둥 ठ용 으용 는 유웡 馬 w는 凹ั ธ U

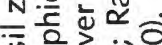

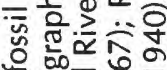
욷휸은 的方

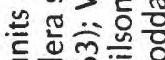
ง 흥후웛 는듄 空 ర্] 든 등 هँ ऊ응 जั ๒ั

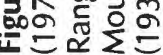




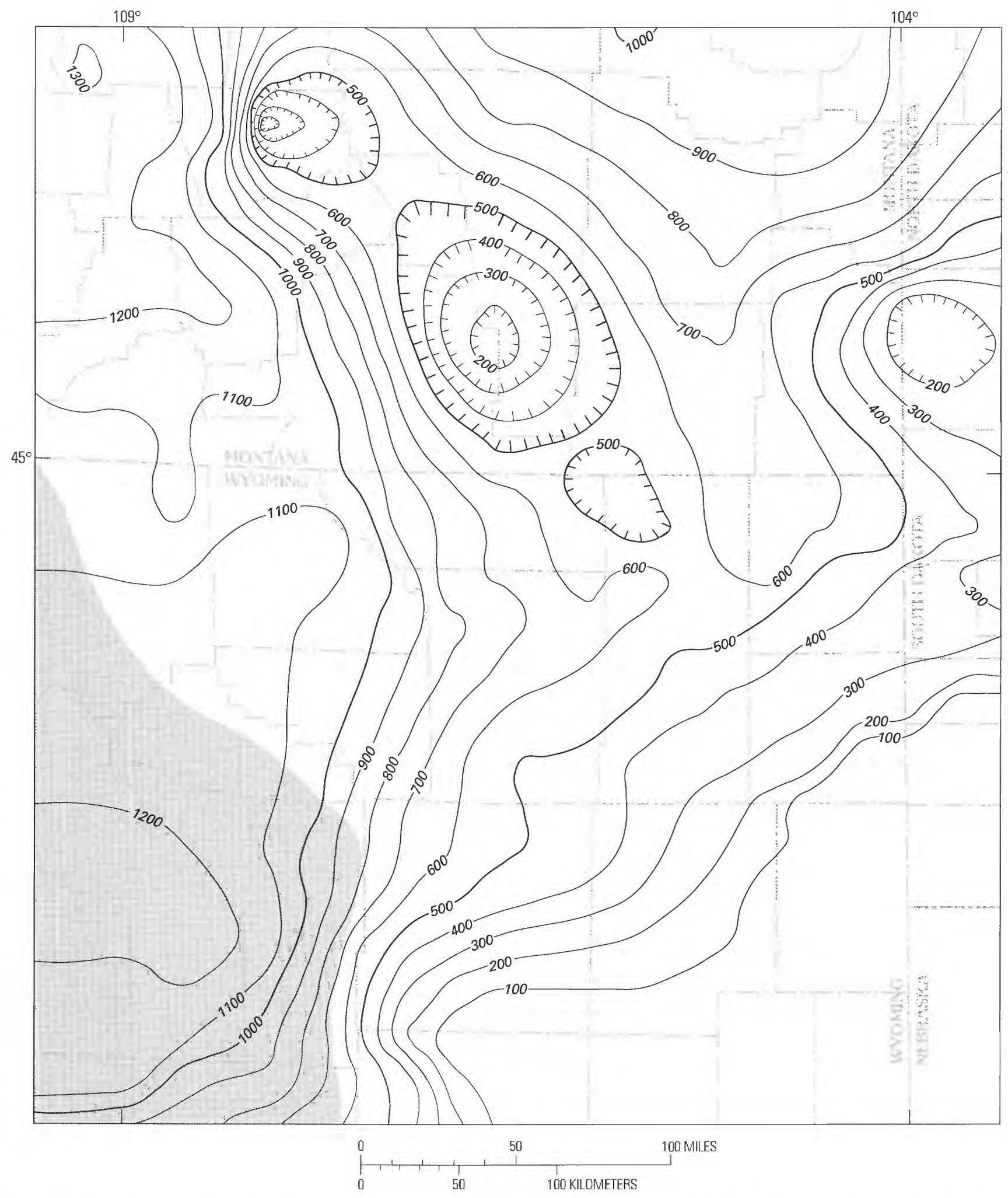

Figure 7. Isopach map of stratigraphic sequence one (Cambrian and Lower Ordovician). Data modified from Downey (1982). Contour interval $100 \mathrm{ft}$ (30.1 m); zero-isopach line not mapped. Based on 91 wells; gridded on an approximately 15 mi by $15 \mathrm{mi}$ grid ( $24 \mathrm{~km}$ by $24 \mathrm{~km}$ ). Cambrian rocks are generally absent from the southeastern corner of the map area except for possible remnants of Flathead Sandstone equivalents in the northern Laramie Mountains (E.K. Maughan, oral commun., 1990). The interval shown on this map includes rocks assigned to the Fremont Canyon Sandstone of Sando and Sandberg (1987). Screened area in southwestern part of map area is an area of very limited control. Map area shown in figure 3. 


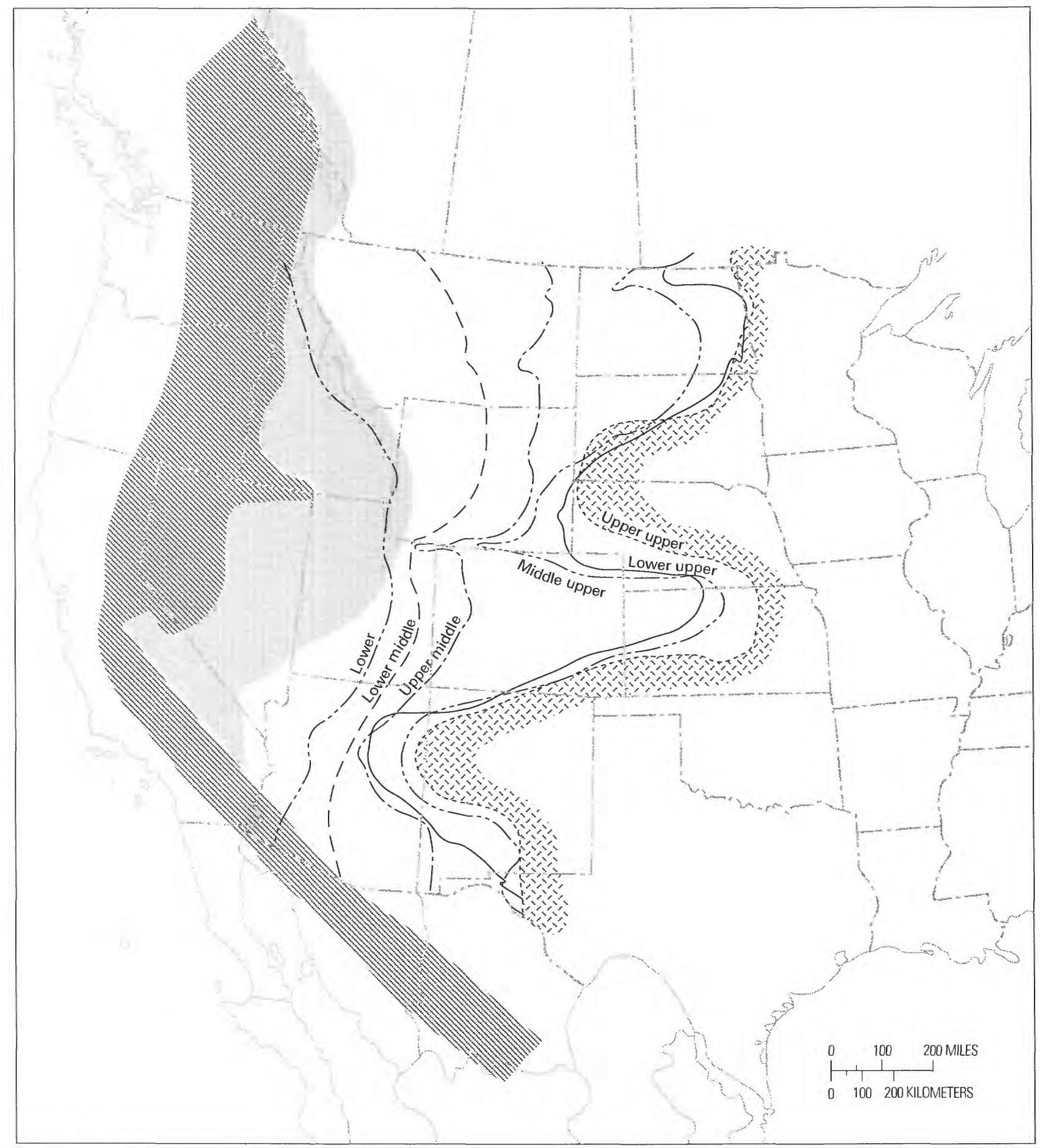

Figure 8. Maximum original eastward extent of Cambrian stages. Random hatch pattern shows maximum eastward extent of Cambrian sedimentation; diagonal rules show area of allochthonous, post-Paleozoic continent; shading indicates area of Mesozoic compression and Tertiary extension and uncertain geometric relationships. Modified from Stewart and Suczeck (1977), after Lochman-Balk (1972).

through Lower Ordovician sequence within the basin area, and subsequent tectonic activity along the western margin influenced deposition throughout the remainder of the early Paleozoic. Tectonic activity along the Ouachita margin (Dickinson, 1981) also influenced deposition on the
Wyoming shelf. Rifting and doming of the margin possibly extended as far northwest as Colorado or Utah (Larson and others, 1985) and created positive areas on the Wyoming shelf. Upper Cambrian and Lower Ordovician rocks along the Ouachita margin in Oklahoma and 


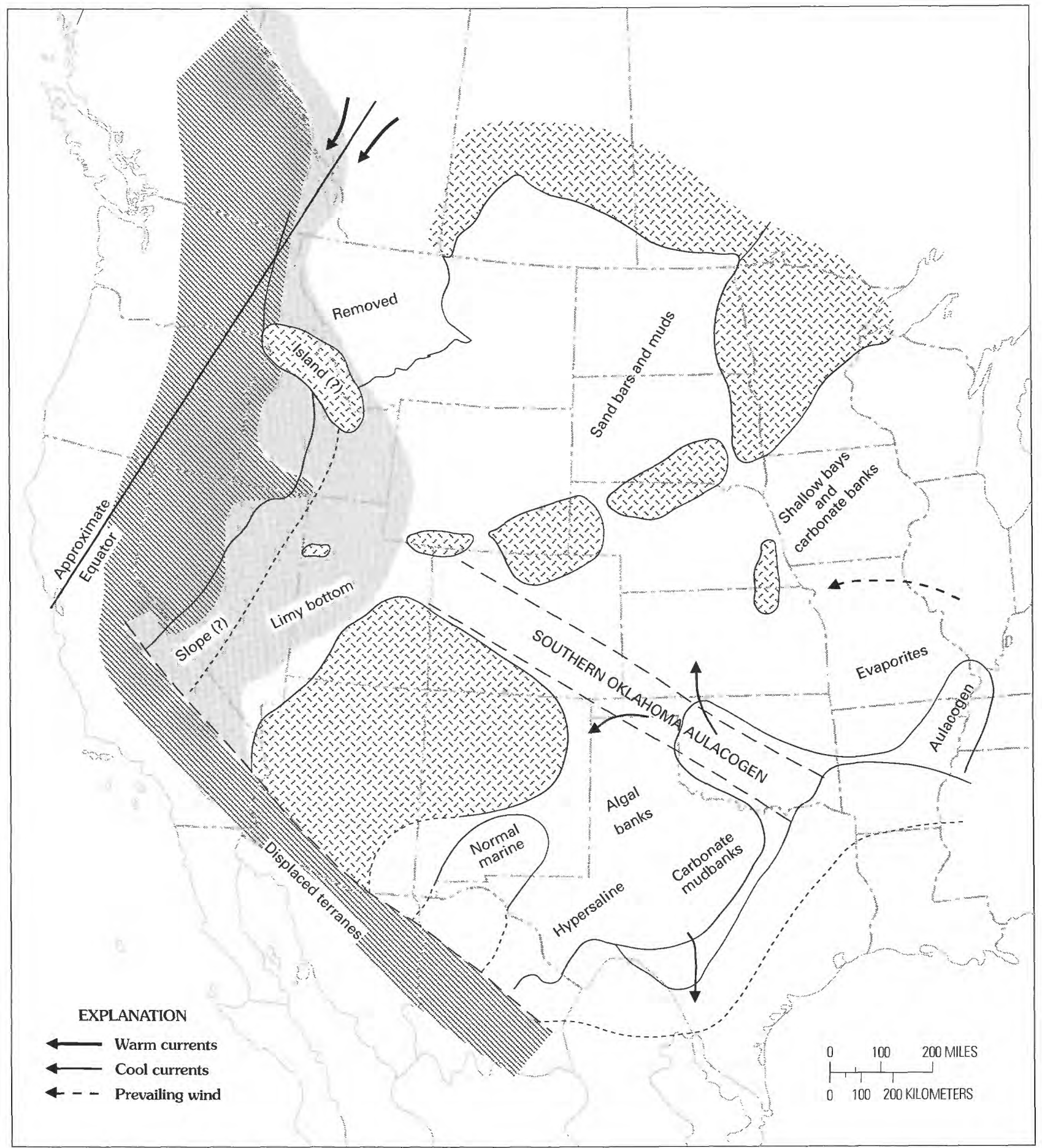

Figure 9. Paleogeography during maximum extent of stratigraphic sequence one (Early Ordovician). Random hatch pattern indicates area of nondeposition (some of these areas may be the result of later erosion and their paleogeographic relationships are uncertain); shading indicates area of uncertain paleogeography because of later compression and extension; diagonal rules show area of allochthonous continent accreted in post-Paleozoic time. Modified from Ross (1976, 1977) and others.

Arkansas record rifting of that margin. Turbidites in the Ouachita Mountains, probably derived from a carbonate shelf to the north and emplaced on a muddy abyssal area (Morris, 1974), indicate that water depth increased through time. Rifting of the Ouachita margin is also expressed as extension within the Colorado trough and probably influenced Middle Cambrian to Early Ordovician basement tectonic activity across the Wyoming shelf. 
The Cambrian seas transgressed eastward onto the craton from the rifted western margin during a period of about $60( \pm 5)$ (Armin and Mayer, 1983) to 100 m.y. (Coles and others, 1983) (fig. 8). This is approximately the amount of time of major thermal subsidence of a shelf after rifting, and almost all Cambrian through Ordovician subsidence of the western Cordilleran miogeocline can be explained by thermal subsidence of the passive margin (Bond and others, 1983). Faulting along the continental margin continued through Silurian time and formed carbonate platforms that were sites for shale deposition during periods of regression (Cecile, 1978, 1982; Bond and Kominz, 1981; Bond and others, 1983).

Although the Williston Basin did not develop as a distinctive circular area of increased subsidence until Middle Ordovician time (Carlson and Anderson, 1965), initial subsidence probably began by early Early Ordovician time (late Tremadocian) (LeFever and others, 1987, fig. 4A). The earliest evidence of increased sediment thickness is within an elongate area along the trend of the Central Montana trough to the west (LeFever and others, 1987, fig. 4A), and initial subsidence may have been related to a branch of a rift arm, similar to the Triassic basins of the East Coast.

The hiatus between stratigraphic sequences one and two (Cambrian-Lower Ordovician and Middle Ordovician-Lower Devonian) (figs. 2, 6) is variable within the study area and represents all or parts of Canadian and early Champlainian time (Witzke, 1980) (fig. 10). Erosional relief of as much as $1,400 \mathrm{ft}(127 \mathrm{~m})$ developed in the middle part of the United States (Berry, 1976). Bond and others (1983) suggested that the regression at the end of the Cambrian-Lower Ordovician sequence is probably due to eustatic sea-level fall, consistent with global sealevel changes proposed by Vail and others (1977).

\section{Paleobiological Controls on Sedimentation}

Middle Cambrian biological changes in carbonate production and sedimentation played an important role in the depositional history of the Powder River Basin area. Evolutionary changes yielded carbonate rocks that are very different from those of Early Cambrian time. Archaeocyathids, the primary skeletal component of late Early Cambrian reefs, became extinct at the end of the Early Cambrian (James, 1983). Lower Middle Cambrian carbonate mounds are primarily algal and contain only scattered invertebrate skeletal elements. Depositional fabrics of bioherms in the epeiric seas are mostly laminated (stromatolitic) or nonlaminated clotted and fenestral (thrombolitic), developed by noncalcified (blue-green) algae and calcified algae, particularly Girvanella, Renalcis, and Epiphyton. Blue-green algae probably dominated buildups on the shelf areas, and calcified algae dominated buildups at or near the continental margin (James, 1983). Cambrian and Lower Ordovician carbonate mounds generally are on the edges of the North American cratonic shelves presumably because the restricted environment and shallow water of the continental interior was inhospitable to the biological assemblage of the cratonic margin (Wilson, 1975). Some mounds did develop, however, along the western edge of the rifted continental margin in Utah and Nevada (Ross and Cornwall, 1961; Church, 1974) and in the depositional area of the Manitou Dolomite of Colorado (Wilson, 1975).

\section{Stratigraphic Units of Sequence One}

Eastward transgression across the thermally subsiding rifted continental margin produced the first depositional sequence in the Powder River Basin area in Middle Cambrian time (Lochman-Balk, 1972) (fig. 8). Regressive cycles and accompanying subaerial exposure periodically interrupted the transgression (Lochman-Balk, 1972; Brown and others, 1984). Stratigraphic sequence one (figs. 6, 12) is shaly carbonate rocks and includes sandstone and argillaceous sandstone, primarily at the base, and almost pure limestone and dolomite, especially in the west (fig. 11). The sequence generally is younger (fig. 8) and more clastic rich to the east (Houston, 1969; Gerhard and others, 1978) (fig. 11).

Depositional units on the shelf are cyclic: each unit begins with the deposition of time-transgressive shaly half-cycle clastics and ends with a time-transgressive transition to the overlying carbonate half-cycle (Aitken, $1981 \mathrm{a}, \mathrm{b})$. The base of the sequence and the transition to carbonate facies generally become younger to the southeast. The tops of the carbonate half-cycles are essentially isochronous and represent a rapid sea-level fall, allowing for local erosion that may have preceded the beginning of the next cycle (Aitken, 1966, 1968, 1978, 1981a, b). The units can be recognized in the subsurface (pls. 1, 2) and should be generally recognizable in the field. The Flathead Sandstone at the base of the sequence is an exception to the above generalizations; it is everywhere progradational on the Precambrian basement.

The shaly half-cycles within the basin area correspond to periods of rapid sea-level rise (Aitken, 1966) and drowning of the western carbonate rim of the shelf. Loss of the carbonate rim allowed increased wave energy to cross the shelf and permitted clastic sediments to be transported farther to the west across the shelf. As a new carbonate rim developed along the western margin, wave energy across the shelf decreased, terrigenous clastics were ponded near the landward margin, and carbonate sedimentation spread over the shelf.

Martin and others (1980) modeled the Middle and Upper Cambrian of central Wyoming (fig. 1) as two disconformable shoaling-upward sedimentary successions on a rimmed shelf. They divided the carbonate depositional environment into three large-scale settings: (1) a 


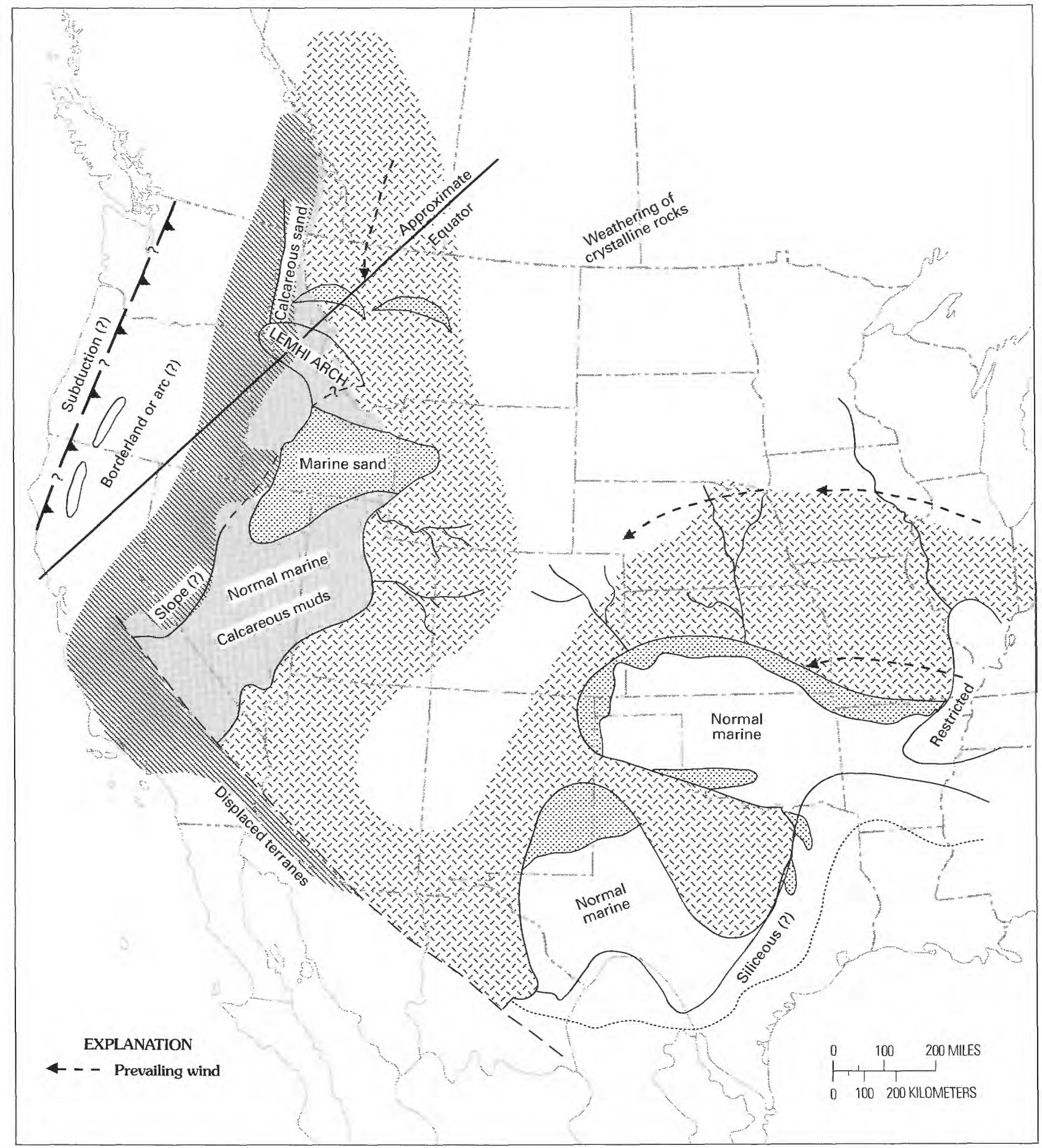

Figure 10. Paleogeography during regression at end of stratigraphic sequence one (early Middle Ordovician). Random hatch pattern indicates area of nondeposition (some of these areas may be the result of later erosion and their paleogeographic relationships are uncertain); shading indicates area of uncertain paleogeography because of later compression and extension; diagonal rules show area of allochthonous continent accreted in post-Paleozoic time. Stippling indicates area of marine sand deposition. Modified from Ross (1976, 1977) and others.

marginal-marine setting to the northwest, (2) an intertidal-supratidal (sabkha) setting in the center, and (3) a marginal or strandline, shallowing-upward epeiric lagoon succession to the east.
The base of the Cambrian and Ordovician sequence on the Wyoming shelf and in the northern Great Plains area is the Flathead Sandstone (figs. 4, 6, 8, pls. 1, 2) and lithostratigraphically equivalent rocks at the base of the 
Deadwood Formation, which unconformably overlies Precambrian igneous and metamorphic rocks. Cambrian stratigraphic units generally recognized in the Powder River Basin include the Flathead Sandstone and the Gros Ventre, Gallatin, and Deadwood Formations. In this report, however, other Cambrian stratigraphic units have been informally extended into the Powder River Basin in the subsurface, primarily from southwestern Montana where the units are more completely developed, in order to demonstrate their equivalency to the Powder River Basin units. The names Gallatin and Gros Ventre Formations are commonly applied to the Cambrian rocks above the Flathead in the western Powder River Basin area and in the Big Horn Basin. I followed Deiss (1939) and Lochman-Balk (1972) and divided the Cambrian section into a series of onlapping shale and limestone sequences, each of which is capped by rocks of a regressive event (Aitken, 1966) (fig. 6). The most pronounced regressions are at the top of the Meagher Limestone and at the top of the Pilgrim Limestone in central Montana (Lochman-Balk, 1972). These divisions correlate generally with those of the Cambrian of the southern Canadian Cambrian System suggested by Aitken (1966) and of the Great Basin Cambrian System proposed by Palmer and Halley (1979).

On plates 1 and 2, I correlated the Flathead Sandstone and the overlying Gros Ventre and Gallatin and equivalent units (equivalents shown in parentheses on the cross sections) from central Montana into the northwestern Powder River Basin (cross section $C^{\prime \prime}-C^{\prime}$ ), along the eastern Powder River Basin from the Williston Basin south to the Denver Basin (cross section $D^{\prime \prime}-D^{\prime}$ ), and from the Big Horn Basin eastward across the northern Powder River Basin (cross section $E-E^{\prime \prime}$ ). The stratigraphic divisions used in this report (fig. 6) follow the rational of "grand cycles" of the Cordilleran miogeocline (Aitken, 1966, 1981a, b; Palmer and Halley, 1979). Aitken (1978) divided the Cambrian of the southern Canadian Rockies into eight grand cycles (fig. 6, column 1) and extended this interpretation to include the Cambrian as far south as Salt Lake City, Utah, and as far east as the Transcontinental arch. The grand cycles of the southern Canadian Cordillera (fig. 6) include the (1) Mt. Whyte-Cathedral, (2) Stephen-Eldon, (3) Pika, (4) Arctomys-Waterfowl, (5) Sullivan-Lyell, (6) Bison Creek-Mistaya, (7) Survey Peak, and (8) Outram-Skoki entirely of Early and Middle(?) Ordovician age (Ordovician Zone $G$ of Ross, 1951).

In the southern Canadian Cordillera, the Gog Group (Lower Cambrian) lies beneath the grand cycle series and is made up of predominantly marine, subtidal and intertidal deposits (Palonen, 1976) but includes piedmont, fandelta, and fluvial deposits in its northernmost outcrop area (Young, 1979). The Gog is unconformable over paleohighs but is apparently conformable with the underlying Windermere Group in paleolows (Young, 1979). The Gog apparently is a regressive sequence and does not fit into the grand cycle scheme. The environments of deposition of the Flathead Sandstone in Wyoming are similar to those of the Lower Cambrian Gog Group in the southern Canadian Cordillera and, like those of the Gog, probably are prograding nearshore environments at the landward margin of a depositional system.

In the following discussion, I assign the stratigraphic units of the basin area to Aitken's $(1966,1968,1978$, $1981 \mathrm{a}$, b) grand cycles and attempt to summarize his observations about the cycles. Because the grand cycles of the Cordilleran miogeocline are incompletely developed in the Powder River Basin area (Palmer, 1971), some of the stratigraphic units used within the study area are combinations of the cycles developed in the miogeocline.

Stratigraphic sequence one is from 0 to about $1,400 \mathrm{ft}$ $(0-427 \mathrm{~m})$ in thickness within the Powder River Basin area (figs. 7,12 , pls. 1, 2). It is thickest along the northwestern margin of the basin and thins by depositional onlap and erosional truncation to an almost east-west zeroedge across the southern end of the basin. McMillen (1989) reported a thickness of $1,700 \mathrm{ft}(518 \mathrm{~m})$ for the Cambrian section in the central Powder River Basin (location not given) based on seismic-reflection profiling, much thicker than suggested by drilling data. The isopach map for the Cambrian through Lower Ordovician sequence (fig. 7) suggests that the Powder River Basin area subsided more slowly than the surrounding areas. In Golden Valley, Treasure, Big Horn, and Rosebud Counties, Montana, and Sheridan County, Wyoming, Cambrian and Lower Ordovician sedimentary rocks are thin (figs. 7, 14, $16,17)$ in an area that I will refer to as the Powder River arch (fig. 5). In the northern part of the study area, the Powder River arch is coincident with an unnamed series of faults identified from gravity data in Yellowstone, Treasure, and Big Horn Counties, Montana, (Brown and others, 1984), and with the trend of the Bearpaw anticline (fig. 18). During deposition of the Flathead Sandstone, the southern part of the Powder River arch coalesced with a second area of thin deposition (fig. 7) between the Kaycee structural trend (fig. 58B) and the Tensleep fault system (fig. 33, 58B), an area that I will call the Sweetwater crest. The influence of the Sweetwater crest is evident, although less well defined, in isopach maps of the Flathead Sandstone-Wolsey Shale-Meagher Limestone equivalent interval (fig. 14), although later erosion has removed part of this interval and subsequent deposits from the area. Clastic sediments of the sequence were probably derived from the Transcontinental arch and are typical of a stable shelf environment (Peterson, 1984).

Dorf and Lochman (1940), Howell and others (1944), and Lochman-Balk (1972) summarized stratigraphy of the Cambrian System in the northern Rocky Mountains area. 


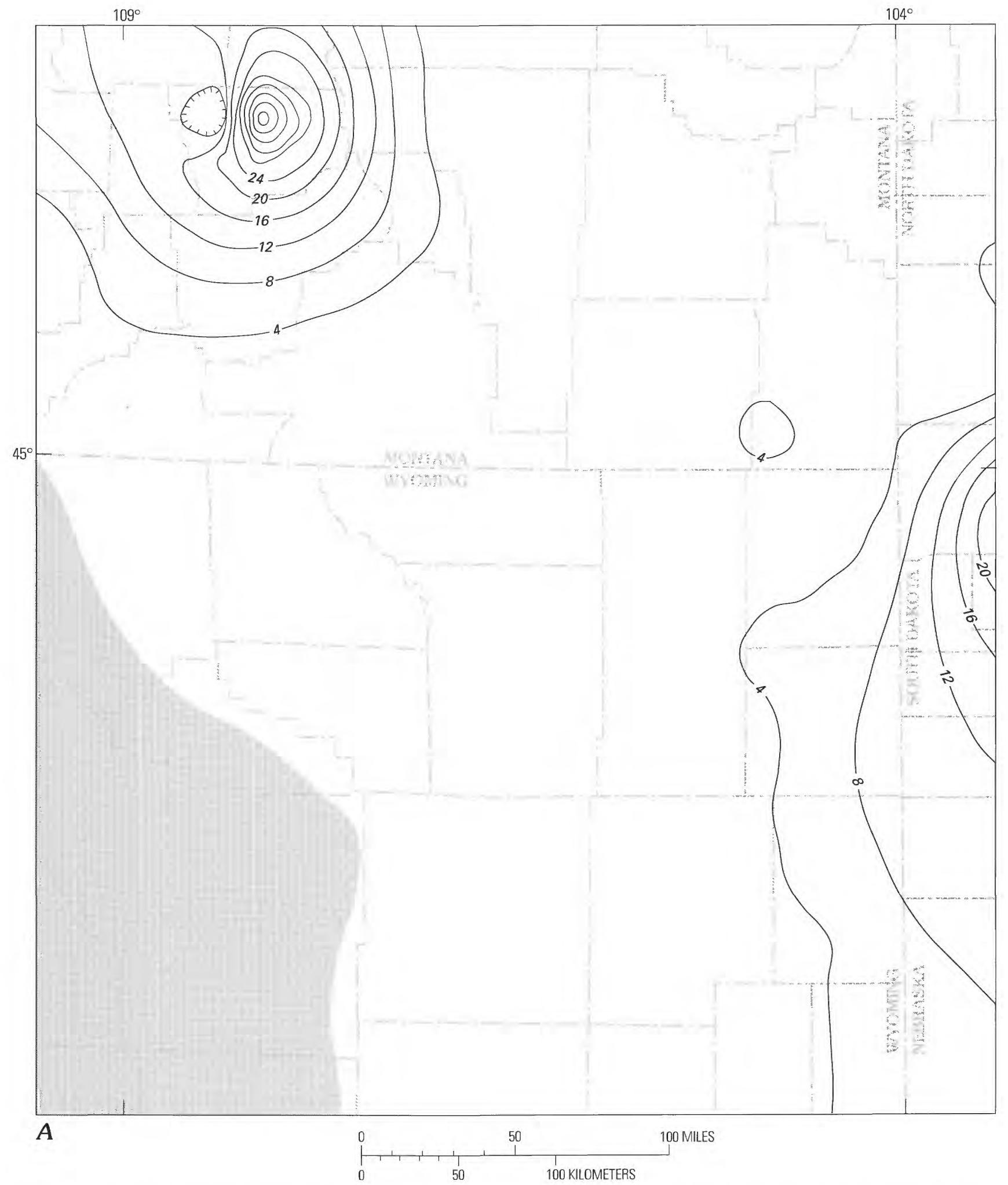

Figure 11. Lithology of stratigraphic sequence one (Cambrian and Lower Ordovician). Map area shown in figure 3. Based on 55 wells; gridded on an approximately $15 \mathrm{mi}$ by $15 \mathrm{mi}$ grid $(24 \mathrm{~km}$ by $24 \mathrm{~km})$; zero-percent lines not mapped. Screened area in southwestern part of map area is an area of very limited control. Data from Downey (1982). A, Dolomite (contour interval 4 percent). 


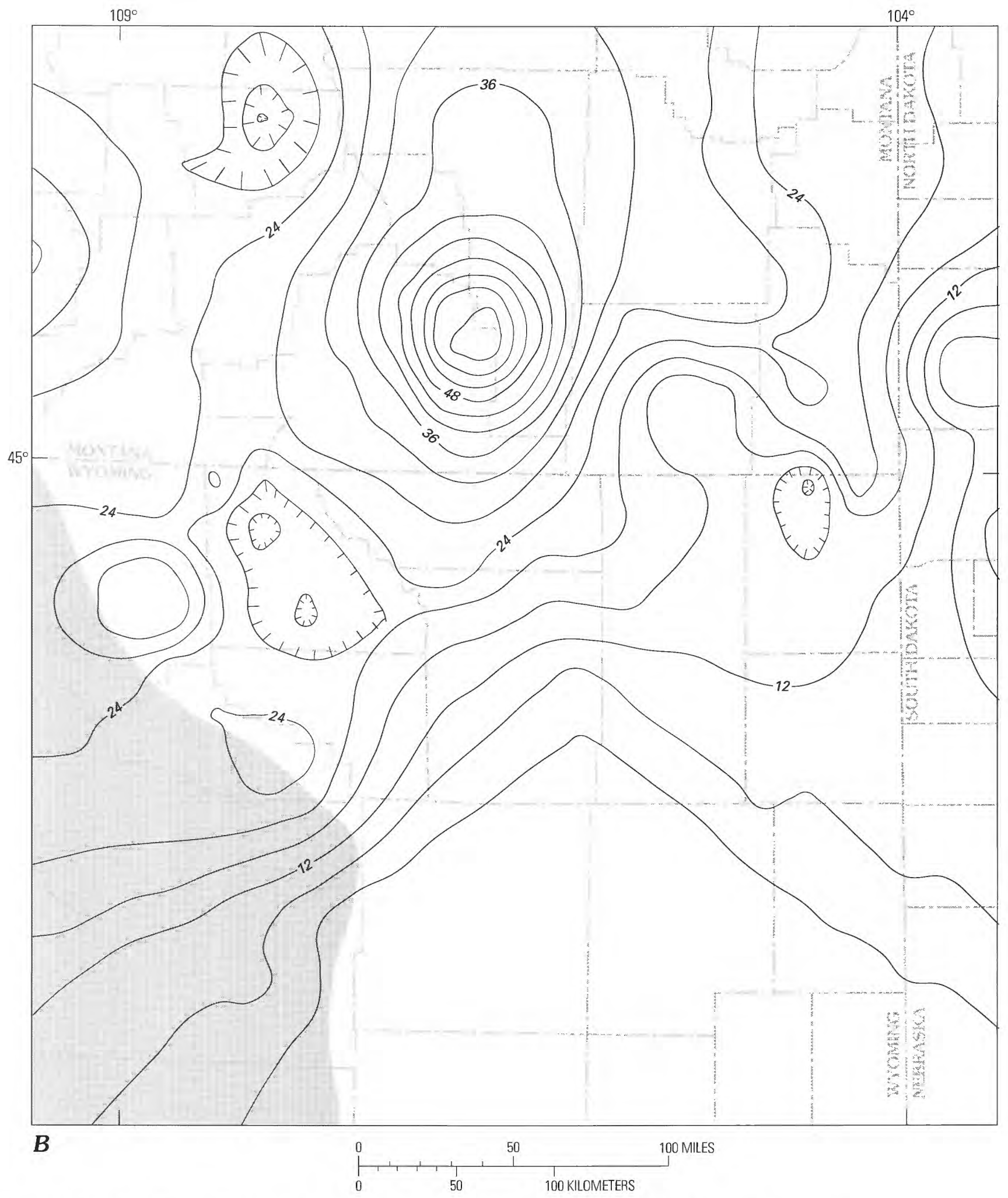

Figure 11 (continued). Lithology of stratigraphic sequence one. B, Limestone (contour interval 4 percent). 


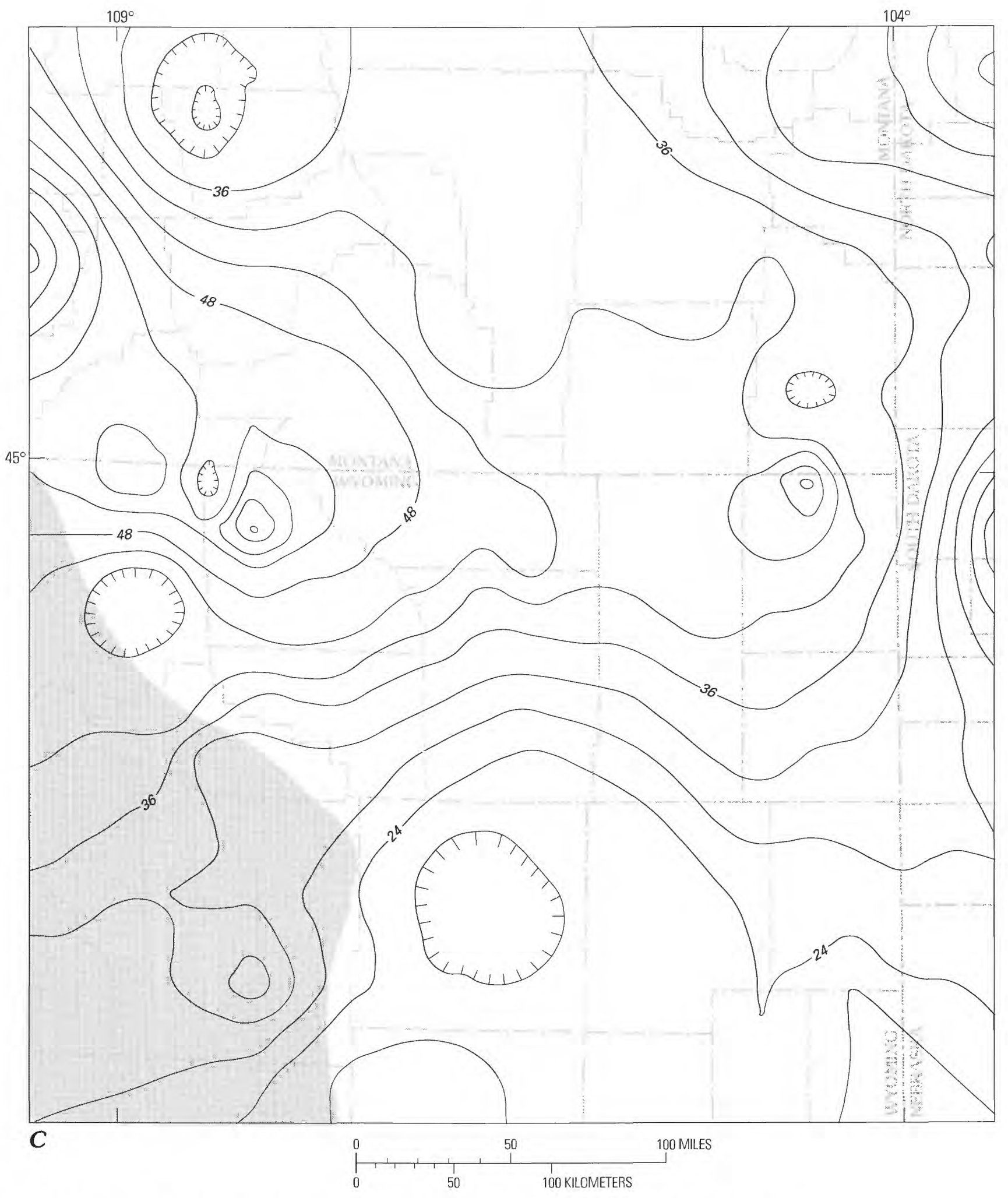

Figure 11 (continued). Lithology of stratigraphic sequence one. C, Shale (contour interval 4 percent). 


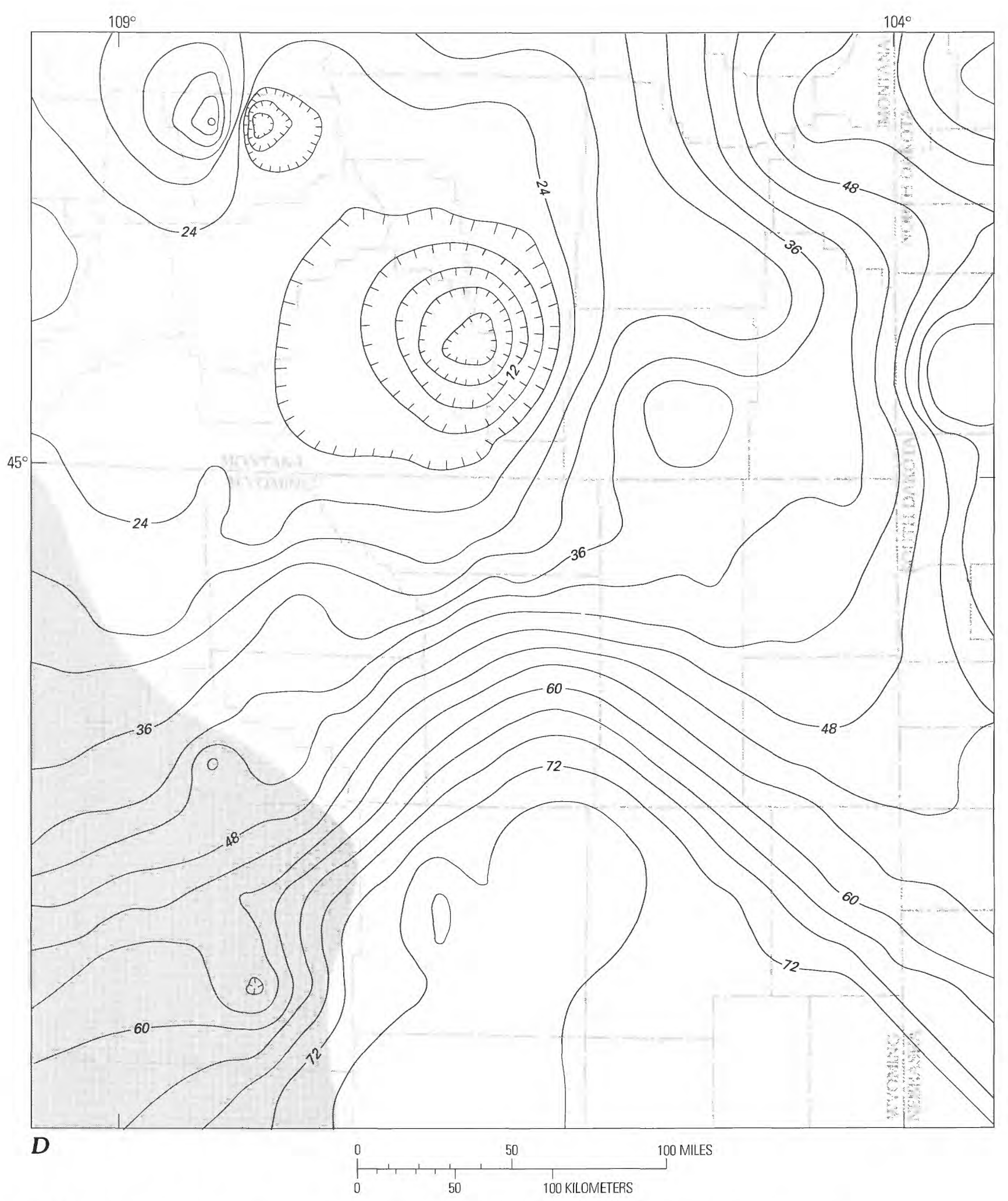

Figure 11 (continued). Lithology of stratigraphic sequence one. D, Sandstone (contour interval 4 percent). 


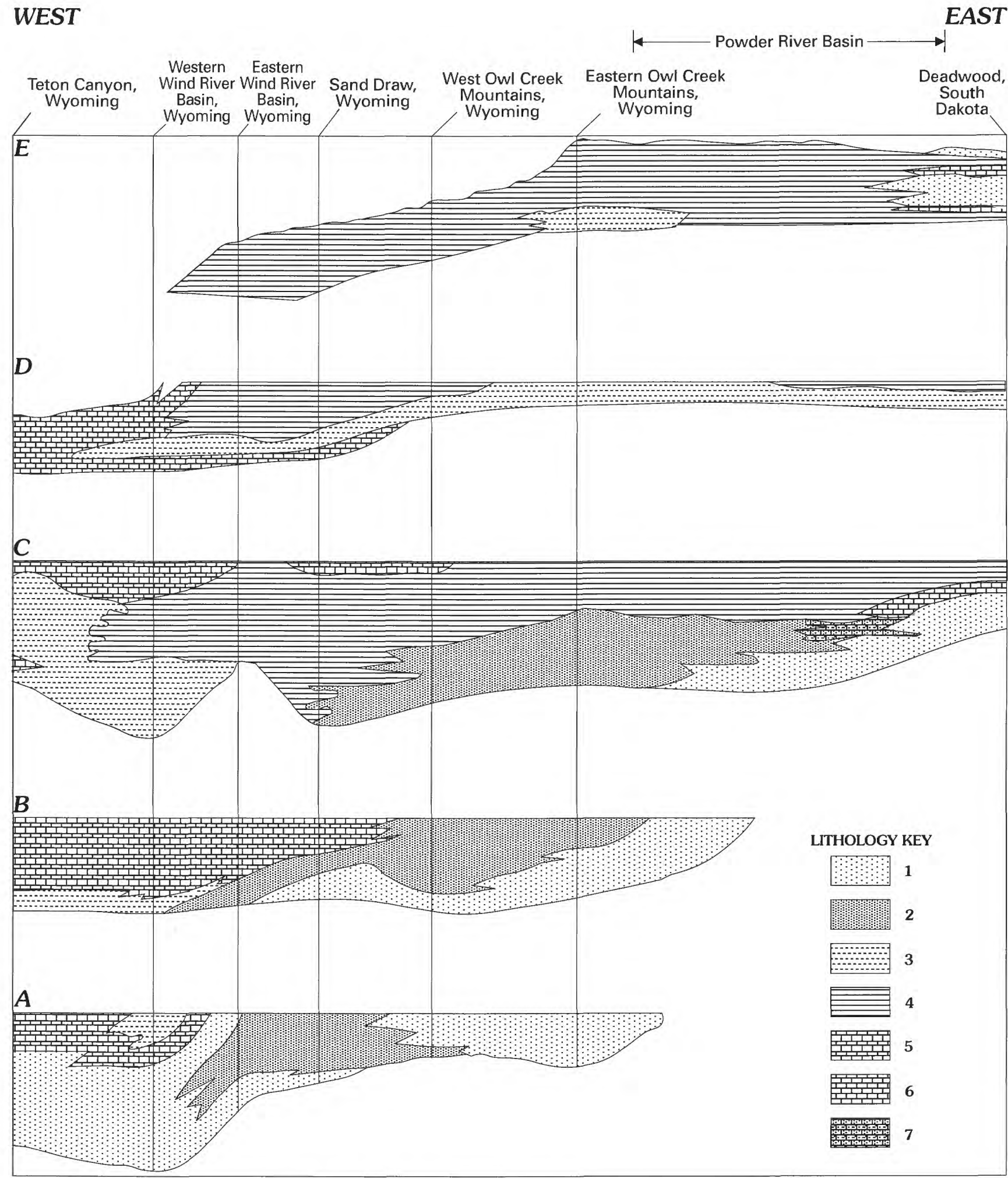

Figure 12. Schematic cross sections of stratigraphic sequence one (Middle Cambrian and Lower Ordovician) in northern Wyoming. Lithology key: (1) conglomerate and medium- to coarse-grained sandstone; (2) sandstone with shale and siltstone; (3) fine-grained sandstone and shale; (4) finegrained sandstone, siltstone, and shale with limestone; (5) limestone and less than 40 percent other rock types; (6) dolo- mite, dolomitic limestone, and stromatolite reef rock; (7) dolomite, dolomitic limestone, and stromatolite reef rock with sandstone. Modified from Lochman-Balk (1972). A, Mt. Whyte-Cathedral cycle. B, Stephen-Eldon cycle. C, Pika and Arctomys-Waterfowl cycles. $D$, Sullivan-Lyell cycle. $E$, Bison Creek-Mistaya and Survey Peak cycles. 


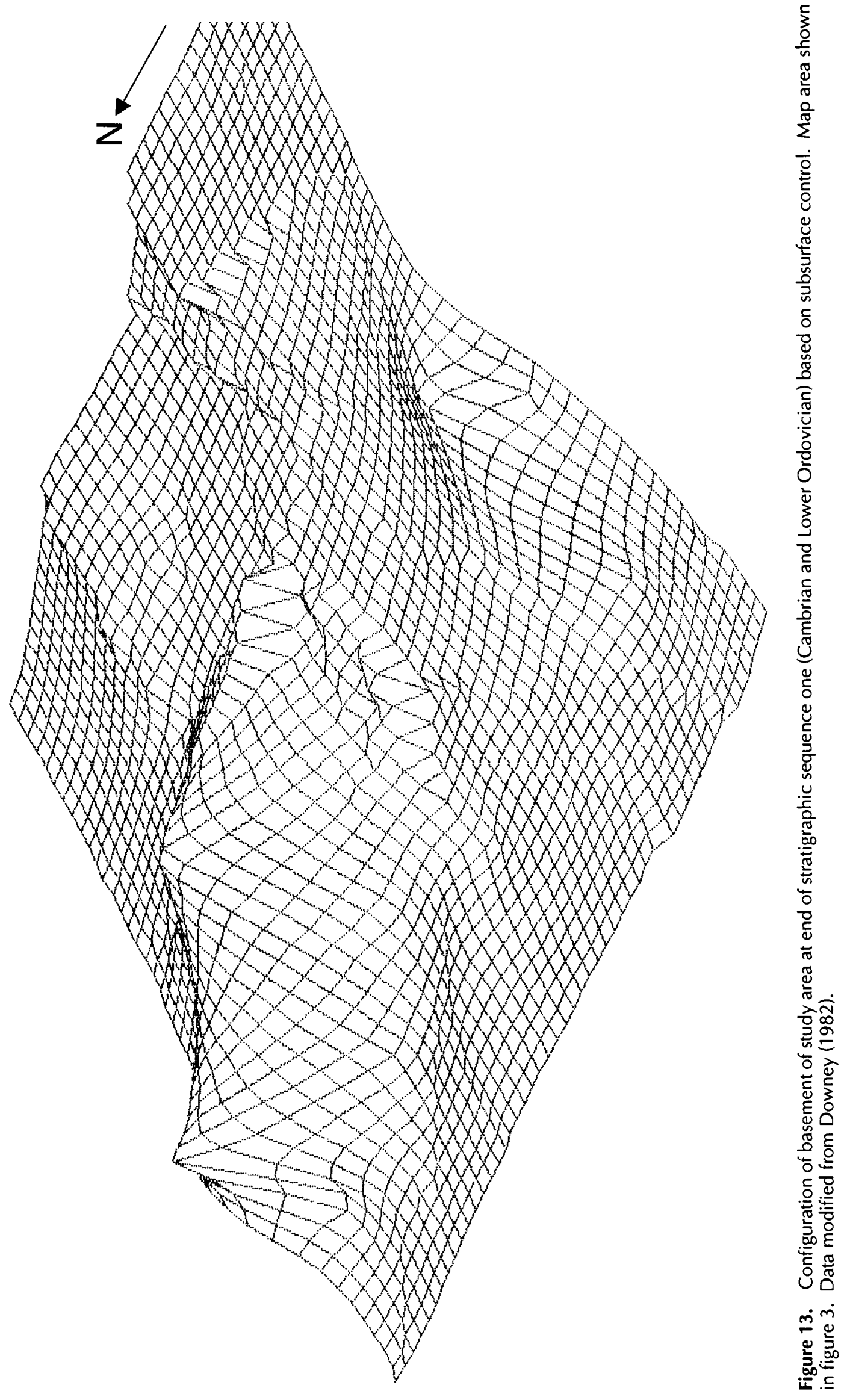




\section{Flathead Sandstone}

The base of the Phanerozoic section in the Powder River Basin area is the Flathead Sandstone (fig. 6, pl. 2). The Flathead or its stratigraphic equivalent is present in all boreholes that penetrate the sequence except well 48 , cross section $E-E^{\prime}$ (pl. 2). In well 48 , the lower part of this interval is calcareous, glauconitic shale similar to the rocks that overlie the Flathead throughout most of the study area. Bell (1970), Bell and Middleton (1978), and Middleton and others (1980) discussed the sedimentology and stratigraphy of the Flathead Sandstone in Wyoming.

The Flathead Sandstone and equivalent rocks are transgressive and range in age from early Middle Cambrian in the Wind River Canyon, Wyoming, west of the Powder River Basin, to earliest Late Cambrian (early Dresbachian) at Deadwood, South Dakota, in the Black Hills to the east (Lochman-Balk, 1972) (figs. 6, 8). The upper part of the Flathead in the Wind River Basin, Wyoming, and near Rawlins, Wyoming, is about the same age as the middle or lower part of the Park Shale of western Wyoming (Shaw and DeLand, 1955), within the Bolaspidella Zone of Lochman-Balk (1972). Throughout the study area, the Flathead and its equivalents are approximately equivalent to the Pika and Arctomys-Waterfowl cycles (Aitken, 1981) as a sandy, basal, transgressive member. An isotopic age of about $550 \mathrm{Ma}$ from presumed authigenic glauconite in the Flathead Sandstone of Montana also suggests a Middle Cambrian age (Chaudhuri and Brookins, 1969).

\section{Isopach Map}

The isopach map of the Flathead Sandstone (fig. 14) in the Powder River Basin area has a predominantly northwest-southeast grain. The Flathead is thin in the presentday Powder River Basin area along the Powder River arch (fig. 5) and thicker to the east along the trend of the Black Hills and the Miles City arch. The Flathead appears to thicken in two distinct basins to the northeast and to the southwest along the trend of the Cedar Creek anticline. The western edges of these basins generally parallel the western margin of the Williston Basin.

In the present-day Big Snowy Mountains area, northwest of the Powder River Basin, the Flathead Sandstone thickens westward of the intersection of the Lake Basin fault trend and the Flat Willow Creek syncline. In the area of the Flat Willow Creek syncline, the Flathead thins rapidly eastward and may be absent in places. The abrupt change in thickness suggests that the Flat Willow Creek syncline-Devils Basin anticline trend defined the western edge of the Powder River arch (fig. 5) during the Middle and Late Cambrian.

The Flathead also thickens to the west of the Powder River arch (fig. 5) in the area of the Permian Sweetwater trough (the proto-Sweetwater trough of this report; figs. 1, 14). North of the proto-Sweetwater trough, near the central part of the Powder River Basin, a broad area of thin Flathead Sandstone is present where the Sweetwater crest intersects the southern Powder River arch. The subcrop pattern of the Flathead Sandstone and succeeding deposits is the result of erosion along the northern flank of the Transcontinental arch prior to Mississippian time.

\section{Regional Lithology and Stratigraphy}

Parkinson (1958) and Bell (1970) have done the only detailed mineralogical analysis of the Flathead Sandstone in Wyoming. The unit is made up of generally more than 90 percent quartz grains having rounded detrital cores surrounded by overgrowths probably derived from pressure solution. Feldspar is generally more abundant at the base of the formation where it may make up 25 percent of the rock; orthoclase and microcline are dominant. Feldspar grains are subangular and generally altered to sericite along the edges. Euhedral authigenic feldspar is present locally. Calcite cement is present in minor amounts filling pores and replaces both framework grains and quartz cement. Hematite and clay also are present in pore spaces and around detrital grains. Minor constituents include lithic fragments (granite, chert, and quartzite), biotite, muscovite, tourmaline (green, brown, and blue), zircon, ilmenite, anatase, and rutile.

Shaw (1957) suggested that the fining-upward basal arkosic sandstone of the Flathead is of fluvial origin. Lochman-Balk (1972) interpreted the Flathead Sandstone to represent braided-stream(?), foreshore, upper shoreface, and subtidal to intertidal deposition on a Precambrian surface that probably had relief of 300-400 ft (91-122 m). The only fossils, other than trace fossils, recovered from the Flathead Sandstone are inarticulate brachiopods (Lingulepis sp.) (Miller, 1936, p. 119; Shaw, 1957; Bell and Middleton, 1978). Trace fossils in the Flathead Sandstone include Scolithos (Boyde, 1966, Wind River Canyon), Diplocraterion, Corophioides, Corophium, and Cruxiana (Bell, 1970), and Sabellarifex, Phycodes, and Plagiogmus (Cloud and Dever, 1973).

In the Wind River Basin, Bell and Middleton (1978) distinguished two units of the Flathead based primarily on the type of stratification. The lower unit is a crossbedded, medium-grained, clean sandstone (texturally mature orthoquartzite) that is commonly well cemented on outcrop. The unit is locally shaly or conglomeratic at the base and is transitional in a few localities to a highly weathered regolith developed on top of the Precambrian. The crossstratified unit is $0-200 \mathrm{ft}(0-61 \mathrm{~m})$ thick, mainly as a function of pre-Flathead topography, and is cut by large channels. The upper, parallel-stratified unit is coarse- to fine-grained, moderately clean sandstone (submature orthoquartzite) at the base grading upward to interbedded 


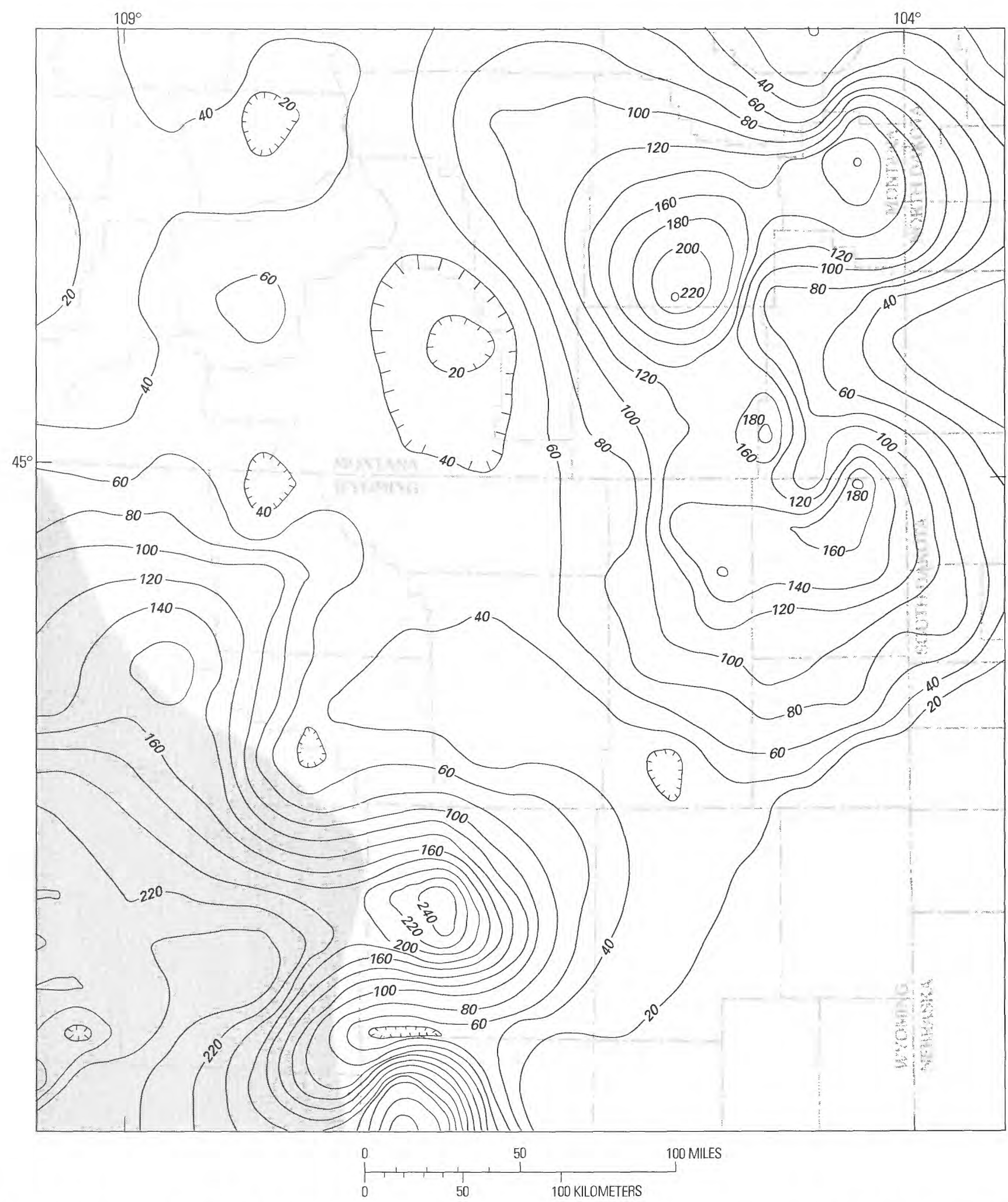

Figure 14. Isopach map of the Flathead Sandstone. Map area shown in figure 3. Contour interval $20 \mathrm{ft}(6.1 \mathrm{~m})$; zero-isopach lines not mapped. Based on 106 wells; gridded on an approximately $15 \mathrm{mi}$ by $15 \mathrm{mi}$ grid ( $24 \mathrm{~km}$ by $24 \mathrm{~km}$ ). Screened area in southwestern part of map area is an area of very limited control. 
fine-grained, shaly sandstone, siltstone, and shale; it is $10-50 \mathrm{ft}(3.1-15 \mathrm{~m})$ thick. Locally, near the top, it may contain iron-rich sandstone, hematite layers, and calcareous sandstone.

In Park County, Wyoming, Bell (1970) interpreted the depositional setting of the basal Flathead Sandstone as a deeply embayed coastline with many offshore islands. The highest energy environments were at the headlands of the embayments and marginal to the offshore islands. Within the embayments themselves, depositional environments were much lower energy (also see Graham and Suttner, 1975). The upper part of the Flathead Sandstone represents mostly low-tide terrace or beach deposits (Bell and Middleton, 1978) and offshore shallow-water marine deposits (Bell, 1970). Parallel and low-angle stratification and an abundance of current ripples suggest deposition in shallow water, and desiccation cracks and raindrop impressions in some outcrops indicate subaerial exposure.

Rocks previously assigned to the Upper Devonian Fremont Canyon Sandstone of Sando and Sandberg (1987) are herein reassigned to either the Middle Cambrian Flathead Sandstone or the Mississippian basal clastic unit of stratigraphic sequence four. Field investigation with E.K. Maughan in the fall of 1989 led to the reassignment of the Fremont Canyon at the type section (NE $1 / 4$ sec. 21, T. 29 N., R. 83 W., Natrona County, Wyoming) to the Flathead Sandstone. The basis for Sando and Sandberg's assignment of the basal sandstone unit at Fremont Canyon to their Fremont Canyon Sandstone is (1) "physical criteria***to compare this sandstone to formations previously established in the northern Cordilleran region" (p. 4) and (2) "compelling circumstantial evidence for a Late Devonian age for the basal sandstone" (p. 7) consisting of Late Devonian-age conodonts from the overlying silty dolomite that they assigned to the Englewood Formation. The physical criteria used by Sando and Sandberg are wholly inadequate as a basis for correlation, and the basal sandstone unit at Fremont Canyon can be traced to the southwest to the Rawlins Hills, where it is the Flathead Sandstone. The Flathead pinches out east of Fremont Canyon and is not present in the northern Laramie Mountains. The conodont evidence for the Devonian age assignment of the silty dolomite (Englewood Formation of Sando and Sandberg) overlying the basal sandstone at Fremont Canyon and its equivalents will be discussed at length in the section on the Mississippian basal clastic unit. Rocks assigned by Sando and Sandberg to the Fremont Canyon Sandstone in the northern Laramie Range and in the Hartville uplift have been included within the basal clastic unit of the Mississippian, following Maughan (1963).

\section{Wolsey Shale and Meagher Limestone Equivalent}

The second stratigraphic interval mapped within the Cambrian through Lower Ordovician sequence is the
Wolsey Shale and Meagher Limestone equivalent (fig. 6, pl. 1). Weed (1899a, b, 1900) named the Wolsey Shale and the Meagher Limestone (fig. 6), and Deiss (1933, 1936, 1938) emended the definitions and designated new type sections. Sloss and Moritz (1951), Shaw and McGrew (1954), Wanless and others (1955), LochmanBalk (1956, 1972), Lochman (1957), Klepper and others, (1957), Knopf (1963), and Robinson and Barnett (1963) all studied the Wolsey Shale to Meagher Limestone equivalent interval in the area surrounding the Powder River Basin. In south-central Montana, the Wolsey Shale contains fossils of the Elrathina Zone (Deiss, 1939; Bell, 1941; Lochman, 1957), the base of the Meagher Limestone is in the Bathyuriscus-Eltrathina Zone, and the top of the Meagher is in the Bolaspidella Zone (LochmanBalk, 1972, fig. 2), suggesting an age equivalence of the Wolsey-Meagher interval to the Stephen-Eldon grand cycle of the Canadian Cordillera (fig. 6).

A gradual initial transgression characterized Wolsey Shale and Meagher Limestone deposition. The carbonate shoal-rim complex of the preceding Early Cambrian cycle farther to the west sheltered the inshore basin from opensea waves and prevented significant deposition of terrigenous mud in the basin. When sea-level rose the carbonate rim was drowned; increased turbulence across the shelf, including the former site of the rim, resulted in deposition of the Wolsey Shale. Basin filling by the Wolsey Shale reduced relief between the basin and its western rim, which became the site of minor ooid and skeletal grainstone deposition. As northeastward transgression continued, the supply of cratonic mud diminished and oolite deposition increased along a narrow, discontinuous rim in Idaho and Utah, possibly extending as far east as western Wyoming and Montana (Aitken, 1978). The reestablished rim reduced wave energy from the open sea and ponded terrigenous mud inshore, allowing deposition of the Meagher Limestone as a subtidal carbonate mud on the shelf to the west of the Powder River Basin area. Deposition of the Meagher led to maximum development of relief of the rim relative to the inshore basin. The Meagher Limestone lithosome expanded northwestward above the terrigenous mud and formed the carbonate half of the grand cycle. The carbonate rim persisted until rapid deepening again drowned the rim, and a new flood of terrigenous mud from the northeast, the Park Shale, initiated the next cycle.

\section{Isopach Map}

In the present-day Powder River Basin area, the Powder River arch (fig. 5) and the Sweetwater crest influenced thickness trends of the Wolsey Shale and Meagher Limestone equivalent interval (fig. 15). In the northeastern part of the study area, sedimentary rocks are thicker along the northern end of the Cedar Creek anticline in 


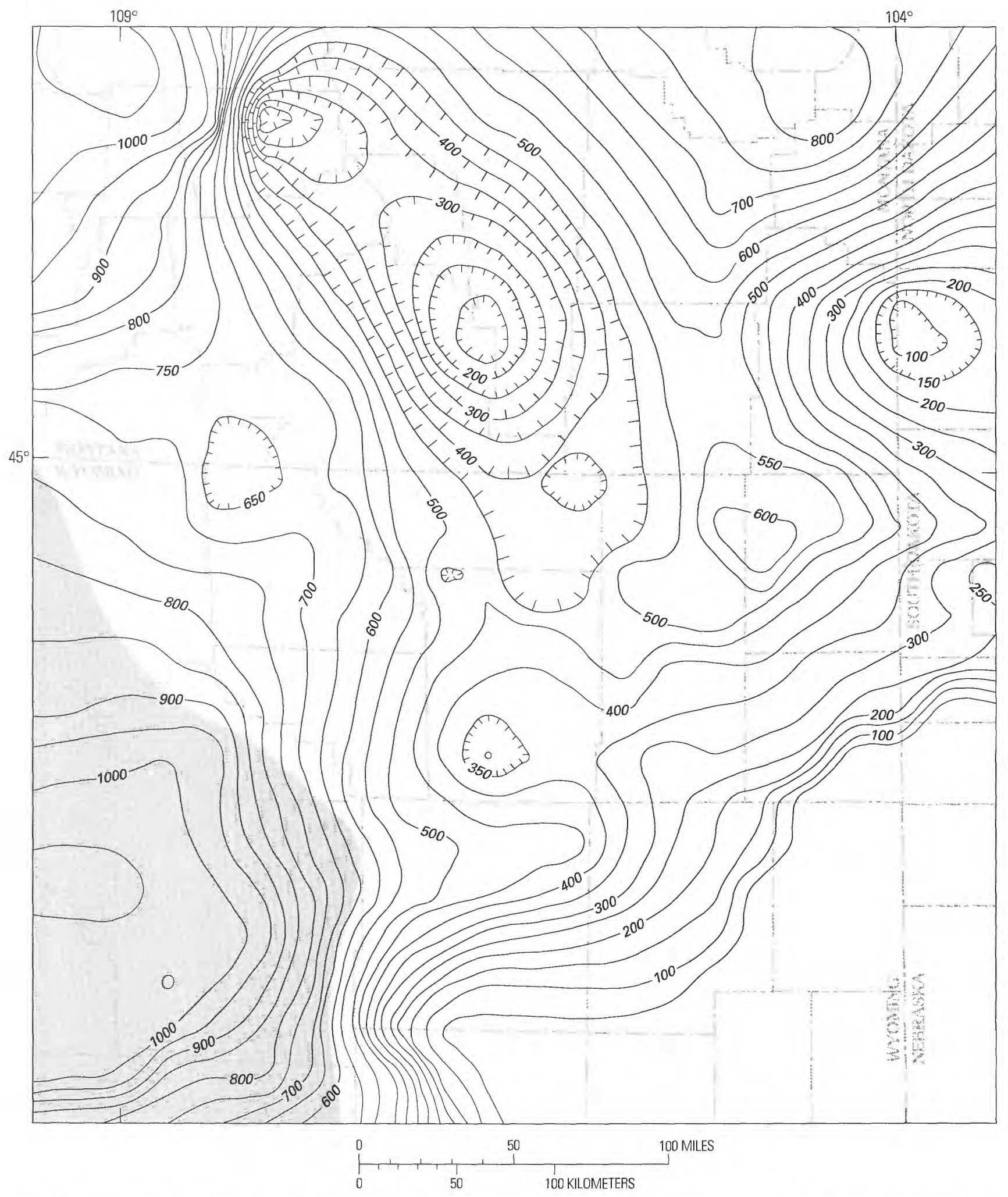

Figure 15. Isopach map of the combined Flathead Sandstone-Wolsey Shale-Meagher Limestone equivalent interval. Contour interval $50 \mathrm{ft}(15.2 \mathrm{~m}$ ); zero-isopach line not mapped. Based on 91 wells; gridded on an approximately $15 \mathrm{mi}$ by $15 \mathrm{mi}$ grid ( 24 $\mathrm{km}$ by $24 \mathrm{~km}$ ). Screened area in southwestern part of map area is an area of very limited control. Map area shown in figure 3. 
the southeastern Williston Basin and thinner to the south (possibly due to post-Cambrian erosion) along the trend of the anticline. Two sub-basins, apparent in the isopachs along the Black Hills-Miles City arch, are present in the Wolsey-Meagher equivalent interval (fig. 15), although they are not as apparent as in the isopachs of the Flathead Sandstone (fig. 14). To the southwest, the area of the proto-Sweetwater trough, also apparent in the isopachs of the Flathead, is also less well defined, probably due in large part to later erosion. The thickest deposits of the Flathead-Wolsey-Meagher equivalent interval may be to the southwest of the present-day basin, although control is sparse in this part of the study area. The increased thickness of the Flathead-Wolsey-Meagher interval both along the margin of the Williston Basin in the northeastern corner of the study area and in the northwestern corner of the study area are better constrained. The Meagher-Wolsey equivalent interval, together with the underlying Flathead Sandstone, is as thick as about $550 \mathrm{ft}$ (168 $\mathrm{m}$ ) in the east-central Powder River Basin and almost $800 \mathrm{ft}(244 \mathrm{~m})$ in the southeastern Williston Basin (fig. 15). The Wolsey-Meagher equivalent interval is more calcareous in the west and coarser grained to the east (pl. 2, cross section $E-E^{\prime}-E^{\prime \prime}$ ).

\section{Regional Lithology and Stratigraphy}

In south-central Montana, the Wolsey and equivalent rocks are generally $200-400 \mathrm{ft}(61-122 \mathrm{~m})$ thick (Robinson and Barnett, 1963). The Wolsey is transitional above the Flathead Sandstone and with the overlying Meagher Limestone (Deiss, 1936). The Wolsey interval shows increasingly restricted environments upward in the section as the basin was filled. The base of the Wolsey consists of shale interbedded with thin lenses of sandstone (Deiss, 1938) and grades upward into micaceous, green, fissile shale, limestone lenses that contain some zones of chocolate-brown fissile shale, and platy interbeds of rustyweathering sandstone that may be slightly calcareous in their upper parts. The upper third of the Wolsey is dominantly chocolate- to maroon-brown fissile shale and interbedded thin, gray, glauconitic, crystalline limestone and several zones of black shale (Deiss, 1938, p. 1330).

In its type area, the Fort Benton and Little Belt Mountains area of Montana, the Meagher (fig. 6) is mainly flatpebble conglomerate of thinly and irregularly, commonly wavy-bedded, gray, mottled limestone that may be sandy or shaly (Weed, 1899b, 1900). The Meagher Limestone consists of thin-bedded, gray to green-gray limestone containing tan and buff, arenaceous clay; the limestone grades upward to green to green-gray, fissile, micaceous shale interbedded with occasional gray and tan-gray, thin-bedded, banded, fine-grained limestone and then to mixed beds of fine- and coarse-grained, thick- and thin-bedded, gray and buff limestone (Deiss, 1936). The unit thickens from the Big Snowy Mountains westward and southward and averages about $258 \mathrm{ft}(79 \mathrm{~m})$ thick in southwestern Montana. The maximum thickness of the Meagher in western Montana is $416 \mathrm{ft}(127 \mathrm{~m})$ at Beaver Creek. The Meagher Limestone is best exposed, most completely developed, and most fossiliferous near Nixon Gulch, in the Three Forks quadrangle, Montana. This is within the area of Peal's (1893) section for the Flathead Sandstone and Gallatin Limestone; here the Meagher is $347 \mathrm{ft}(106 \mathrm{~m})$ thick and is correlated with Peale's "Trilobite limestone" at the base of Gallatin, for which Peal gave a thickness of $120 \mathrm{ft}(37 \mathrm{~m})$. In south-central Montana, the Meagher is about $500 \mathrm{ft}(152$ $\mathrm{m}$ ) thick and is interpreted as a shallow-water marine unit (Robinson and Barnett, 1963).

In north-central Montana, in the southern Elkhorn Mountains on the southern edge of the Alberta shelf, the Wolsey Shale is $368 \mathrm{ft}(112 \mathrm{~m})$ thick. The lower half is greenish-gray, drab shale and some interbedded sandstone and limestone, and the upper half of the unit is interbedded gray, shaly limestone and greenish- and yellowishgray, calcareous mudstone and shale. This change in lithology upward reflects a decrease in the supply of siliceous clastic material into the basin. Many beds are micaceous, and some are glauconitic (Klepper and others, 1957). The overlying Meagher Limestone is $490-570 \mathrm{ft}$ $(149-174 \mathrm{~m})$ thick and consists of a middle unit of medium-gray or medium-bluish-gray, indistinctly thick bedded limestone between upper and lower units that are more thinly and more distinctly bedded carbonate rocks. The middle unit accounts for about half the thickness of the formation, and upper and lower units share the rest of the thickness about equally (Klepper and others, 1957).

In the northern Boulder batholith area, the average thickness of the Wolsey Shale is $200 \mathrm{ft}(61 \mathrm{~m})$. The Meagher Limestone overlies the Wolsey and consists of a lower thin-bedded dolomitic limestone, $360 \mathrm{ft}(110 \mathrm{~m})$ thick, and an upper massive pure limestone, $280 \mathrm{ft}(85 \mathrm{~m})$ thick (Knopf, 1963).

In the Williston Basin, the Wolsey equivalent is about $250 \mathrm{ft}(76 \mathrm{~m})$ thick and consists of olive-drab, arenaceous, micaceous shale near the base grading upward to darkpurple and green, fissile shale containing very thin limestone nodules near the top (Lochman-Balk, 1956). In the Little Rocky Mountains, at the extreme western edge of the Williston Basin, the Meagher equivalent is only $1-2 \mathrm{ft}$ (0.3-0.6 m) thick (Lochman-Balk, 1956). Here the Meagher equivalent grades upward from thin-bedded, mottled, locally fossiliferous and dolomitic limestone to oolitic, pelletoidal, massive, mottled, light- to dark-gray, slightly fossiliferous intraclastic sparite, and finally to thin, mottled, dolomitic, limestone containing fossil hash and, locally, pellets and algal pisolites (Lebauer, 1965).

In western Wyoming, the Wolsey Shale and equivalent rocks range from $86 \mathrm{ft}(26 \mathrm{~m})$ in thickness in the 
Gros Ventre Range to $607 \mathrm{ft}$ (I85 m) in thickness in the Snake River Range and consist primarily of greenish-gray shale and flat-pebble conglomerate and interbeds of green glauconitic or red hematitic sandstone, as well as red shale, hematitic oolite (in the Gros Ventre and Teton Ranges), and black shale (in the upper part, in the Gros Ventre and Teton Ranges). The Wolsey of western Wyoming is thickest in the Snake River Range, where it lacks sandstone and the strongly colored red, green, or black shale but contains more than 70 beds of blue-gray limestone totalling almost $300 \mathrm{ft}(91 \mathrm{~m})$ (Wanless and others, 1955). This lithology suggests an eastward expansion of the carbonate rim (Aitken, 1978). Similar limestone sequences are present in the Little Rocky Mountains (Deiss, 1936, p. 1276).

In the Wind River Basin, the Depass Formation (Miller, 1935, 1936) is equivalent to the upper part of the Meagher and the lower part of the Park Shale (fig. 6) and shows younging of the base from west to east across central and eastern Wyoming (Lochman-Balk, 1972). In the northwestern Wind River Basin, the Meagher equivalent (the Death Canyon Limestone of the Gros Ventre Group of Shaw, 1957) is interpreted as deposited on a stable shelf dotted by marine banks and shoals (Lebauer, 1965).

\section{Park Shale and Pilgrim (Du Noir) Limestone Equivalent}

The third interval of Cambrian to Lower Ordovician rocks in the Powder River Basin is equivalent to the Park Shale and Pilgrim Limestone (fig. 6, pls. 1,2) and represents deposition of the Pika and the Arctomys-Waterfowl grand cycles of the Canadian Cordillera and the lower part of the Sullivan-Lyell grand cycle.

Weed (1899a, 1899b, 1900) named the Park Shale and Pilgrim Limestone (fig. 6) but did not designate type sections. Deiss (1936) emended the original definitions and designated a type section for the Park Shale in the Little Belt Mountains and redefined the Pilgrim Limestone as the basal formation of the Upper Cambrian in Montana and Yellowstone Park. Dorf and Lochman (1940), Lochman (1950), Sloss and Moritz (1951), Shaw and McGrew (1954), Lochman-Balk (1956), Klepper and others (1957), Richards (1957), Hanson (1962), Knopf (1963), Robinson and Barnett (1963), and Martin and others (1980) all studied the Park-Pilgrim equivalent interval in areas surrounding the Powder River Basin.

On the Wyoming shelf, the basal Park Shale represents the Pika cycle (fig. 6). The Pika cycle in the southern Canadian Rocky Mountains is within the lower (but not lowermost) Bolaspidella Zone, and the Middle Cambrian-Upper Cambrian boundary is either very near the top of the shale half-cycle (the Arctomys) or within the carbonate halfcycle (the Waterfowl) (Aitken, 1981a). The Park Shale may be the temporal equivalent of the Pika and most, if not all, of the Arctomys-Waterfowl cycles of Aitken (1981b). The Park Shale rests with apparent conformity on the Meagher Limestone and represents part of a tidal mudflat deposited following the post-Meagher Limestone regression (Martin and others, 1980). Like the Pika cycle in the Canadian Cordillera, the Pika cycle on the Wyoming shelf is incompletely developed. In the Canadian Cordillera, the Pika cycle shows incomplete development of the shale halfcycle, and the lower part of the Park Shale on the Wyoming shelf shows analogous poor development of the carbonate half-cycle; thus this cycle may have involved only a small eustatic sea-level change. A second possible interpretation is that the lower shale and middle calcareous members of the Park Shale represent the Pika cycle on the Wyoming shelf, and the base of the upper member represents the overlying Waterfowl cycle. Dating of the Park Shale, however, is insufficiently accurate to discriminate between these two possible interpretations.

The upper part, and possibly the middle part, of the Park Shale and basal Pilgrim Limestone are equivalent to the Arctomys-Waterfowl cycle of the Canadian Cordillera (fig. 6). The Arctomys-Waterfowl cycle shows the development of evaporative conditions, marked by salt clasts and vugs after gypsum, indicative of a shallow basin during the shale half-cycle within the Canadian trough, although the carbonate half-cycle does not suggest hypersaline conditions. The high intertidal or supratidal deposits of the upper part of the Park Shale on the Wyoming shelf (Martin and others, 1980) probably represent basin filling. The high content of coarser detrital sediments in the Arctomys-Waterfowl cycle suggests a major regression at the beginning of the Arctomys-Waterfowl cycle (Aitken, 1966; Pugh, 1971).

The upper part of the Pilgrim Limestone was deposited during the beginning of the Sullivan-Lyell cycle (fig. 6). The Sullivan cycle began with a rapid transgression onto the shelf following a regression at the end of the Waterfowl cycle. As the influx of terrigenous clastics diminished the carbonate shoal to the west was reestablished, and during the maximum transgression a broad carbonate shoal complex developed to the west of the interior basin.

The Sullivan-Lyell cycle on the Wyoming shelf may be made up of two cycles rather than a single cycle as in the Canadian Cordillera (fig. 6). Available dating (primarily summarized by Lochman-Balk, 1972) suggests that the Waterfowl-Sullivan boundary in the Canadian Cordillera is within the Pilgrim Limestone on the Wyoming shelf. The unconformity at the top of the Pilgrim Limestone (Lochman-Balk, 1972) is within the Lyell Formation of the Canadian Cordillera. This unconformity is just below the top of the Dresbachian Dunderbergia(?) Zone (Lochman-Balk, 1972) and near the middle of the Lyell carbonate-half cycle of the SullivanLyell cycle. At about this horizon, a clastic tongue that extends into the Lyell (Aitken, 1978, 1981a, b) may 
correspond to the hiatus developed on the Wyoming shelf. The unconformity between the Dresbachian and Franconian sections on the Wyoming shelf suggests that the shelf was a high during this interval, whereas sedimentation was continuous in the areas to the north and south. An unconformity between the Park Shale and the base of the Pilgrim Limestone in the northwestern Wind River Basin (Martin and others, 1980) suggests a short, possibly local, tectonic disturbance within the central part of the Wyoming shelf that may be related to the apparent uplift that followed deposition of the Pilgrim elsewhere. The Dry Creek Shale and the basal Sage Limestone Members of the Snowy Range Formation may, therefore, represent a subcycle within the Sullivan-Lyell grand cycle. The whole grand cycle would be capped by the basal Open Door Limestone and its equivalents.

All or part of the Aphelaspis Zone is missing in many places in southwestern Wyoming because of a short but widespread interval of erosion in post-Aphelaspis time (Shaw and DeLand, 1955). The post-Aphelaspis unconformity also is present in the Philipsburg quadrangle of Montana between the Hasmark Dolomite and the Red Lion Formation, in the Bridger Range between the Pilgrim Limestone and Snowy Range Formation, in Death-Teton Canyons between the Du Noir and Open Door Formations, in Wind River Canyon between the Du Noir Limestone and Snowy Range Formation, and at Deadwood, South Dakota, between the upper and lower members of the Deadwood Formation. All three Dresbachian faunal zones (Cedaria, Crepicephalus, and Aphelaspis) are present within the Pilgrim Limestone in the Yellowstone Park area (Deiss, 1936), in southern Montana (Dorf and Lochman, 1940), and in southwestern Wyoming (Shaw and DeLand, 1955). The hiatus between the upper and lower parts of the Sullivan-Lyell cycle (fig. 6) has not been recognized in the Little Rocky Mountains in the Emerson Formation, in Glenwood Canyon, Colorado, or within the Big Snowy Mountains in the Central Montana trough (Lochman-Balk, 1972); this suggests that the Wyoming shelf was a relatively positive area during Dresbachian-Franconian time (Brown and others (1984) did not note this) but that depositional patterns were complicated by local structural movements.

\section{Isopach Map}

Within the Powder River Basin area the Park ShalePilgrim Limestone equivalent interval is as much as about $220 \mathrm{ft}(67 \mathrm{~m})$ thick in the east-central part of the basin, just to the west of the Montana-North Dakota-South Dakota State lines and more than $280 \mathrm{ft}(85 \mathrm{~m})$ thick in the western part of the basin area. In the southeastern Williston Basin the Park-Pilgrim equivalent interval is more than $220 \mathrm{ft}(67 \mathrm{~m})$ thick (fig. 16). Both the Powder
River arch (fig. 5) and the proto-Sweetwater trough (fig. 1) probably strongly influenced the distribution of rocks of the Park-Pilgrim equivalent interval.

\section{Regional Lithology and Stratigraphy}

At the type section in the eastern Little Belt Mountains, the Park Shale is at least $212 \mathrm{ft}(65 \mathrm{~m})$ thick, but its base is not exposed (Deiss, 1936). Its maximum thickness in the type area is estimated to be about $330 \mathrm{ft}(101 \mathrm{~m})$ on Keegan Butte in the Little Belt Mountains, and the formation averages about $100 \mathrm{ft}(30 \mathrm{~m})$ thick throughout Madison and Gallatin Counties, Montana (Robinson and Barnett, 1963), where it is dominantly green-gray, very fissile, almost unfossiliferous, slightly micaceous shale (Deiss, 1936). The Pilgrim Limestone (fig. 6) is thick- and thin-bedded, light- and dark-gray, crystalline to finegrained, irregularly bedded limestone containing variable amounts of irregularly disseminated tan and buff clay; interbedded limestone in 2-20-in. (51-508 mm)-thick beds is gray-green, tan, and maroon, shaly lithographic limestone flat-pebble conglomerate. From its type area, the Pilgrim Limestone thins southwestward from a maximum thickness of $661 \mathrm{ft}(201 \mathrm{~m})$ in the Big Snowy Mountains to $172 \mathrm{ft}(52 \mathrm{~m})$ on Crowfoot Ridge in Yellowstone Park (Deiss, 1936). In Montana north of Yellowstone Park, Hanson (1957) considered the Pilgrim Limestone essentially Dresbachian in age and overlain by the Red Lion or, locally, the Middle and Upper Devonian Maywood Formation. The Pilgrim comprises four rock types: limestone conglomerate; crystalline limestone; oolitic limestone, some of which has distinctive mottling; and dolomite. Because Lochman and Duncan (1944) drew the ParkPilgrim boundary to coincide with the Middle CambrianUpper Cambrian boundary, Hanson (1952) redefined the boundary and drew it to conform with the lithologic change from shale to limestone. In the area east and southeast of Livingston, Montana, Richards (1957) described the Pilgrim Limestone as $175 \mathrm{ft}(53 \mathrm{~m})$ thick and the first cliff-forming unit above the Precambrian. The lowermiddle and upper parts of the Pilgrim are the beds Peale (1893) called "Mottled limestone" in the Gallatin Formation of his Three Forks section (Deiss, 1936).

In the Centennial Range, in southwestern Montana, the Park Shale is $125 \mathrm{ft}(38 \mathrm{~m})$ of shaly beds that rest conformably and transitionally on the Meagher Limestone (Sloss and Moritz, 1951). In the western and southern part of Montana, the lower-middle and upper parts of the Pilgrim Limestone consist of massive, thick-bedded, finely crystalline, gray limestone that is oolitic and mottled drab tan or buff.

In the southern Elkhorn Mountains, Klepper and others (1957) measured 380-510 $\mathrm{ft}(116-155 \mathrm{~m})$ of Pilgrim Dolomite and divided the formation into three members: a lower unit, about $50 \mathrm{ft}(15 \mathrm{~m})$ thick, of principally 


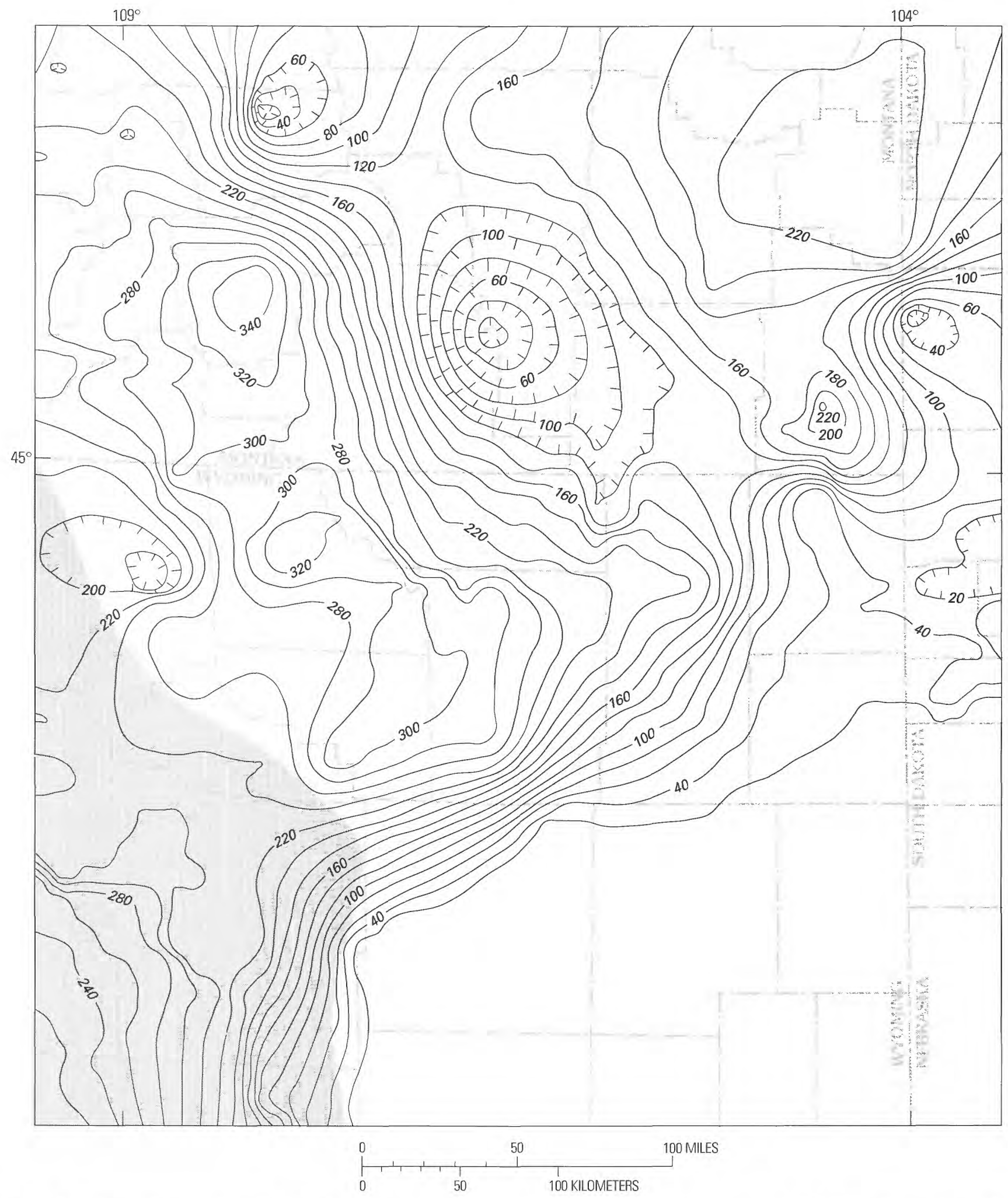

Figure 16. Isopach map of the Park Shale-Pilgrim Limestone equivalent interval. Contour interval $20 \mathrm{ft}(6.1 \mathrm{~m})$; zero-isopach line not mapped. Based on 99 wells; gridded on an approximately 15 mi by 15 mi grid ( $24 \mathrm{~km}$ by $24 \mathrm{~km})$. Screened area in southwestern part of map area is an area of very limited control. Map area shown in figure 3. 
mottled light-gray and dark-gray crystalline dolomite; a middle unit, about $175 \mathrm{ft}(53 \mathrm{~m})$ thick, of light-gray and medium-gray crystalline limestone and irregular ribbons of yellowish-gray silty dolomite; and an upper unit, 150-225 $\mathrm{ft}$ (46-69 m) thick, of light-gray, mediumcrystalline to sugary, rough-weathering dolomite in indistinct beds $0.5-4 \mathrm{ft}(0.15-1.2 \mathrm{~m})$ thick. In the Montana fold-belt province, Robinson and Barnett (1963) described complete sections of the Pilgrim Limestone between 400 and $450 \mathrm{ft}(122-137 \mathrm{~m})$ thick and interpreted the unit as deposited partly in shallow disturbed water and partly in deep quiet water.

Near Red Lodge, Montana, the Park Shale contains two members (Dorf and Lochman, 1940): an upper unit, about $100 \mathrm{ft}(30 \mathrm{~m})$, of thick-bedded, occasionally oolitic, crystalline limestone, light-gray to buff with some mottling, and a lower unit of gray-green edgewise flat-pebble conglomerate and gray-green shale. The average thickness of the formation is $175 \mathrm{ft}(53 \mathrm{~m})$, the maximum thickness is $200 \mathrm{ft}(61 \mathrm{~m})$, and the minimum thickness is $150 \mathrm{ft}(46 \mathrm{~m})$; the variation in thickness is attributed entirely to variability in the amount of clastic material in the lower member.

On the western edge of the Williston Basin, the Park Shale ranges from $215 \mathrm{ft}(66 \mathrm{~m})$ in thickness in the southern Elkhorn Mountains of north-central Montana, exclusive of andesite sills (Klepper and others 1957), to $350 \mathrm{ft}$ $(107 \mathrm{~m})$ in thickness in the Little Rocky Mountains (Lochman-Balk, 1956). In the Little Rocky Mountains, the Park equivalent interval consists of dark-green, fissile, fossiliferous shale that is light green and calcareous in the upper part. Near the top of the interval are thin gray limestone-intraformational conglomerate beds and beds composed of small nodules of trilobite coquinas containing a Middle Cambrian fauna. The upper contact is gradational through $57 \mathrm{ft}(17 \mathrm{~m})$ of predominantly shale beds into the overlying Pilgrim Limestone equivalent (Lochman, 1950; Lochman-Balk, 1956). The lower part of the Pilgrim Limestone contains more shale than the upper and middle parts, and the lower part of the Pilgrim is also shalier here than in western and southern Montana and Yellowstone Park as would be expected from the grand cycle concept. In Blaine and Phillips Counties, Montana, Lochman (1950) described $538 \mathrm{ft}(164 \mathrm{~m})$ of the Pilgrim Limestone as intercalated green shale, thin gray limestone, and gray-green limestone-pebble conglomerate, the upper $100 \mathrm{ft}(30 \mathrm{~m})$ of which is reddishbuff and contains a Late Cambrian fauna including Dresbachian, Franconian, and probable Trempealeauan equivalents.

In western Wyoming, the Park Shale ranges in thickness from $108 \mathrm{ft}(33 \mathrm{~m})$ in the Teton Range (Shaw and McGrew, 1954) to $159 \mathrm{ft}(48 \mathrm{~m})$ in the Snake River Range (Wanless and others, 1955). In southwestern Wyoming, the Park Shale contains a late Middle and earliest Late
Cambrian (Cedaria Zone) fauna. The Middle CambrianUpper Cambrian boundary is within the upper $100 \mathrm{ft}$ (30 m) of the top of the formation, and the top of the unit is within the lower Dresbachian (Shaw and DeLand, 1955; Lochman-Balk, 1972).

In the Wind River Basin, to the west of the Powder River Basin, Martin and others (1980) divided the Park Shale into a green shale at the base, deposited in tidal flats and in shallow shore lagoons, and an upper limestone interval. The upper limestone interval is further subdivided into three major facies: (1) a basal facies containing lime mud deposited in lagoons or ponds (the "sublittoral shelfswale-mud lithotope" of Lochman-Balk, 1971), shaly micrite deposited on tidal flats, and flat-pebble conglomerate of tidal creeks; (2) a middle intertidal to low supratidal facies that includes thinly bedded and laminated deposits with disrupted laminae and gravel formed in channels, levees, beach ridges, and tidal-flat platforms and laminated limestone interpreted as algal mats; and (3) an upper facies that accumulated in high intertidal or supratidal platform and elevated, well-drained areas. Martin and others (1980) divided the Du Noir (Pilgrim equivalent) Limestone into two facies: (1) a lower facies of mainly lagoonal and intertidal deposits, including local tidal-channel deposits, and (2) an upper facies, characterized by shallow lagoonal carbonate mud containing allochthonous oolites transported by storm-generated waves.

Wilson (1985) did the only detailed subsurface study of the Cambrian within the Powder River Basin. He (p. 6) studied core from the Shell Oil No. 1 Clear Creek well (sec. 11, T. 57 N., R. 78 W.) in Sheridan County, Wyoming (near well 27 , sections $C^{\prime}-C^{\prime \prime}$, pl. 1 , and $E-E^{\prime}$, pl. 2), within the Upper Cambrian section. I interpret Wilson's study interval as within the Park Shale-Pilgrim Limestone equivalent interval and the overlying Snowy Range equivalent interval. Wilson interpreted the Upper Cambrian of the northern Powder River Basin areas to have been deposited within a relatively shallow, lowenergy marine basin that was protected on the seaward side by a peritidal bank.

\section{Snowy Range Formation Equivalent}

Deposition of the Snowy Range Formation equivalent in the Powder River Basin (fig. 6, pls. 1, 2) began during the last part of the Sullivan-Lyell grand cycle and continued through the Bison Creek-Mistaya and Survey Peak cycles and the Lower Ordovician Outram-Skoki cycle. In western Wyoming, an Elvinia Zone fauna near the base of Open Door Limestone (Shaw and DeLand, 1955) (fig. 6) suggests an equivalence with the Lyell Formation of the Sullivan-Lyell grand cycle and supports the supposition that the basal Open Door Limestone represents the upper Sullivan-Lyell cycle. A Conaspis Zone fauna within the 
Open Door Limestone correlates approximately with the beginning of the Bison Creek-Mistaya cycle (fig. 6).

The youngest Cambrian unit on the west side of the Powder River Basin is equivalent to the Grove Creek Member of the Snowy Range Formation (fig. 6) (Lochman-Balk, 1972). The unit is $160 \mathrm{ft}(49 \mathrm{~m})$ thick near Sheridan, Wyoming, thins to the south, and is absent near Mayworth, Wyoming. The lower part of the unit contains some Franconian trilobites, and the top $20 \mathrm{ft}(6 \mathrm{~m})$ contains Symphysurina, which suggests either a Trempealeauan or Early Ordovician age (Durkee, 1953). In Tongue River Canyon, the Grove Creek is $167 \mathrm{ft}(51 \mathrm{~m})$ thick and contains Symphysurina spicata, Orthis sp. indet., Arapahoiella albertensis, Pedersonella sheridanensis, Parabolinoides burki, Westonia iphis, and Acrotreta sp. indet. Orthis cf. O. paucicostata Ulrich and Cooper is present 50 $\mathrm{ft}(15 \mathrm{~m})$ below the base of the Bighorn Dolomite in the Crazy Woman Creek section. The Grove Creek equivalent interval consists primarily of light- to dark-gray, in part sandy, platy limestone that includes some sandy zones and common flat-pebble intraformational conglomerate.

The Snowy Range equivalent interval is more clastic rich than the underlying Park Shale-Pilgrim Limestone equivalent interval. Clastics within the Snowy Range interval probably represent a change from coarse-grained, fluvially derived quartz sand in the Park-Pilgrim interval to fine-grained, eolian-derived sand and silt in the Snowy Range (Wilson, 1985).

The base of the Red Lion-Open Door-Snowy Range equivalent is at about the Dresbachian-Franconian boundary in northern Wyoming and southern Montana (Lochman-Balk, 1972) (fig. 6). Although an Irvingella major Zone fauna is near the base of the Snowy Range in the Beartooth Mountains area of south-central Montana and northern Wyoming, Dorf and Lochman (1940) did not include the Grove Creek Member in the Snowy Range Formation although it was later included by LochmanBalk (1956). Elvinia Zone fossils, including Cammaraspis plana and Elvinia tetonensis, are at the base of the Open Door Limestone; near the top of the zone Irvingella is locally common, and Billingsella and Taenicephalus cordillerensis mark the Conaspis Zone within the Open Door Limestone (Shaw and DeLand, 1955). A Prosaukia Zone (uppermost Franconian) fauna is in the Snowy Range Formation (fig. 6) in the Beartooth Mountains of south-central Montana and northern Wyoming (Dorf and Lochman, 1940). Saukia Zone fauna are present in the Snowy Range equivalent interval in the Bridger Range and the Little Rocky Mountains of Montana and at Wind River Canyon, Wyoming, and Deadwood, South Dakota.

\section{Isopach Map}

The Snowy Range Formation equivalent has mostly been removed from the Powder River Basin area, although it is thicker than $200 \mathrm{ft}(60 \mathrm{~m})$ along the western edge of the study area (fig. 17). The Powder River arch (fig. 5) is still evident in the isopachous pattern, although it is less pronounced than in the underlying units.

\section{Regional Lithology and Stratigraphy}

The Snowy Range Formation was first described in southern Montana (Dorf and Lochman, 1938, 1940) and in the Wind River area of Wyoming (Deiss, 1938). The name Snowy Range has been used for the upper member of the Gallatin Limestone in the Gros Ventre and northern Hoback Ranges (Nelson and Church, 1943) for rocks considered to be the same age as the Red Lion Formation in the area north of Yellowstone Park (Hanson, 1952). Richards (1957) adopted the name Snowy Range Formation in the area east and southeast of Livingston, Montana. The Snowy Range Formation includes (in ascending order) the Dry Creek Shale, Sage Limestone, and Grove Creek Members in central Montana (Lochman, 1950). Martin and others (1980) modeled depositional environments of the Open Door Limestone of the northwestern Wind River Basin, and Brett and others (1983) discussed aspects of the petrology of the Snowy Range in the Beartooth Mountains.

At its type locality, near Snowy Range Ranch, Park County, Montana, the Snowy Range grades upward from gray-green fissile shale and thin sandstone beds (average $75 \mathrm{ft}(23 \mathrm{~m})$ thick) to shale and limestone-pebble conglomerate and a single horizon (about $10 \mathrm{ft}(3 \mathrm{~m})$ thick) of dense light-gray limestone. At the top of the Snowy Range, the gray-green fissile shale includes many beds and lenses of glauconitic limestone flat-pebble conglomerate (average $150 \mathrm{ft}(46 \mathrm{~m})$ thick) (Dorf and Lochman, 1938, 1940). In the area east and southeast of Livingston, Montana, the formation is $175 \mathrm{ft}(53 \mathrm{~m})$ thick and is made up of a lower $36-\mathrm{ft}(11 \mathrm{~m})$-thick unit of greenishgray shale, a middle $33-\mathrm{ft}(10 \mathrm{~m})$-thick unit of flat-pebble limestone conglomerate overlain by limestone, and an upper 106-ft $(32 \mathrm{~m})$-thick unit of poorly exposed interbedded greenish-gray shale and light-gray dense crystalline glauconitic limestone. The lower $34 \mathrm{ft}(10 \mathrm{~m})$ of these beds may be stratigraphically equivalent to Peal's (1893) Dry Creek Shale, and the remainder of the formation is in part correlative with and in part younger than Peale's "Pebbly limestone" (Richards, 1957). In the Wind River area, the Snowy Range is $308 \mathrm{ft}(94 \mathrm{~m})$ thick (Deiss, 1938).

In the Bridger Range, a sharp lithologic change marking the contact between the lower Trempealeauan Sage and Grove Creek Members of the Snowy Range Formation (Lochman-Balk, 1972) (fig. 6) suggests that the transition from the Sage Member to the Grove Creek Member is the transition from the shaly half-cycle to the carbonate half-cycle of the Bison Creek-Mistaya cycle. A 


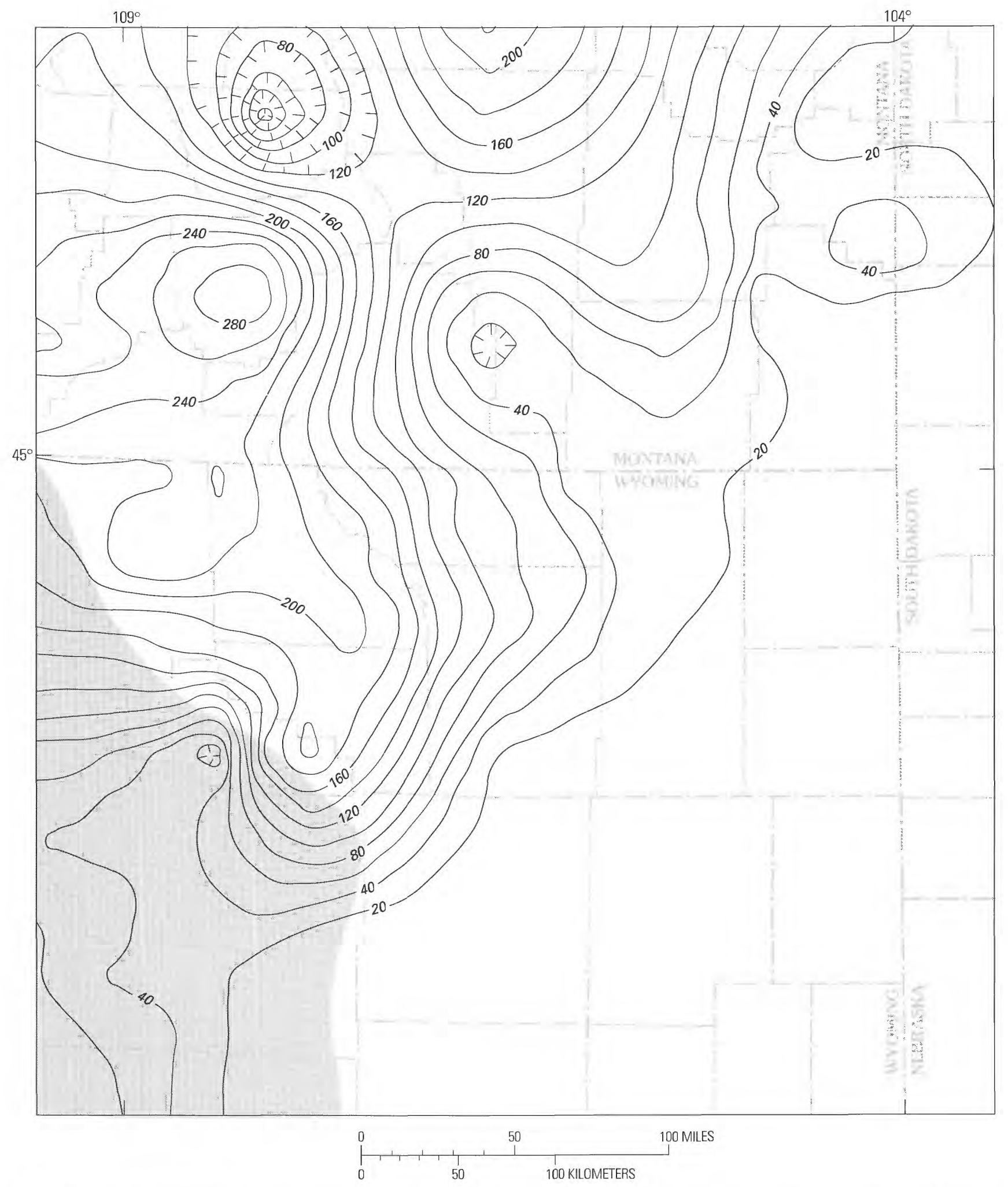

Figure 17. Isopach map of the Snowy Range Formation equivalent interval. Contour interval $20 \mathrm{ft}(6.1 \mathrm{~m})$; zero-isopach line not mapped. Based on 99 wells; gridded on an approximately $15 \mathrm{mi}$ by $15 \mathrm{mi}$ grid $(24 \mathrm{~km}$ by $24 \mathrm{~km}$ ). Screened area in southwestern part of map area is an area of very limited control. Map area shown in figure 3. 
color change from yellowish- to gray-green also suggests a change from more oxidizing to more reducing conditions. The base of the Grove Creek is predominantly limestone pebble conglomerate that grades upward to platy dolomite. In southwestern Montana, the thickness of the Grove Creek Member ranges from 20 to $47 \mathrm{ft}(6-14 \mathrm{~m})$ and averages $35 \mathrm{ft}(11 \mathrm{~m})$ (Dorf and Lochman, 1940). Well-rounded, greenish-coated limestone pebbles having very little or no limestone matrix dominate the conglomeratic limestone facies of the Grove Creek. The variable thickness of the Grove Creek is attributed to pre-Bighorn Dolomite erosion and variation in the amount of clastics in the Grove Creek. The Grove Creek is primarily Trempealeauan in age and contain Eurekia Zone trilobite fauna in the Beartooth Range of south-central Montana and northern Wyoming and a Scaevogyra Zone fauna in at least some sections (Dorf and Lochman, 1940). Symphysurina in the Pryor and Bighorn Mountains (Shaw, 1954) and a Bellefontia Zone fauna (Lochman and Duncan, 1950) within the Grove Creek of central Montana and extreme northeastern Wyoming indicate an Early Ordovician age.

In the Wind River Basin (fig. 1), green shale at the base of the Open Door Limestone (fig. 6) is interpreted as epeiric lagoonal deposits (Martin and others, 1980). Most of the limestone of the Open Door is thought to represent local shallow-subtidal environments (Irwin, 1965) between a higher energy strandline and a more seaward low-energy zone below effective wave base. The rippled and thinly laminated sediments in the Open Door Limestone were deposited in small, very shallow intertidal lagoons under the influence of wind-generated waves. The thick bioturbated units that dominate the Open Door Limestone are thought, however, to represent shallow-subtidal shelf deposition as the strandline migrated farther inland in response to transgression. Late Cambrian deposition is interpreted to show gradual shallowing of the lagoons at the end of the last Cambrian transgression (Martin and others, 1980).

An erosion surface beneath the Lander Sandstone Member of the Bighorn Dolomite is evident in all sections, and erosion has stripped the Open Door down to its oldest Franconian beds in most western Wyoming sections (fig. 6). A 5-10-ft (1.5-3 m)-thick dark-red-stained weathering band on top of the Open Door marks the top of the Cambrian section (Shaw and DeLand, 1955).

\section{Deadwood Formation}

In the Black Hills and eastern Powder River Basin, the base of sequence one is the Deadwood Formation, which has been divided into four units (Lochman-Balk, 1972). The basal member of the Deadwood contains, in ascending order, the Cedaria, Crepicephalus, and Aphelaspis Zones, which are the equivalents of the Waterfowl to lower Sullivan-Lyell subcycles (fig. 6). The second member contains the Elvinia Zone and a thin zone containing Conaspis fauna and represents the upper part of the Sullivan-Lyell and the lower part of the Bison Creek cycles. Much of this interval is shale, limestone, and the characteristic limestone-pebble conglomerate. Glauconitic beds also are present in this member. The third member contains the Prosaukia, Ptychaspis and Saukia Zones, equivalent to the upper part of the Bison Creek-Mistaya and the lower part of the Survey Peak cycles. The fourth unit of the Deadwood in the Black Hills is Lower Ordovician sandstone (the Scolithus, or Scolithos beds) that corresponds to the Survey Peak cycle, with Zone $G$ (Ross, 1957) possibly a part of the Outram-Skoki cycle.

Lochman-Balk and Wilson (1967) reviewed trilobite and brachiopod fauna of the Deadwood Formation and assigned a Dresbachian (Dunderbergia? Zone) age to the base. They also noted fossils of the Cambrian Elvinia, Conaspis, Ptychaspis-Prosaukia, and Saukia Zones (Franconian and Trempealeauan age), as well as fossils of the Lower Ordovician trilobite Zones $A, B, C, D, E$, and $G$ (of Ross, 1951).

Darton (1901) named the Deadwood Formation (fig. 6, pls. 1,2 ) in the Black Hills, South Dakota, and considered it to be Cambrian in age, although he gave no basis for the age assignment. Near Deadwood, South Dakota, Jagger (1904) divided the Deadwood Formation of the Williston Basin into five units (in ascending order): 0-30 ft $(0-9 \mathrm{~m})$ of conglomerate; $30 \mathrm{ft}(9 \mathrm{~m})$ of shale and limestone; $200-400 \mathrm{ft}(61-122 \mathrm{~m})$ of shale, flaggy limestone, and sandstone; 5-12 ft (1.5-3.7 m) of Scolithos sandstone; and $20-40 \mathrm{ft}(6-12 \mathrm{~m})$ of shale overlain by the Whitewood Limestone. At the type locality, Darton (1909) described $404 \mathrm{ft}(123 \mathrm{~m})$ of Deadwood Formation divided into six units and listed fossils from the formation. Darton and Page (1925) revised the upper contact in the Black Hills to include a buff and gray sandstone bed that Darton (1909) had previously assigned to the basal part of the overlying Whitewood Limestone. Condra and others (1931) and Meyerhoff and Lochman (1934, 1935, 1936) extended the name southward in the subsurface of northwestern Nebraska on the Chadron arch and assigned a Late Cambrian age to the unit based on trilobites. In Spearfish Canyon in the Black Hills, Lochman (1950) assigned an Early Ordovician age to the upper part of the Deadwood Formation based on trilobites.

McCoy (1952) excluded the Scolithos sandstone from the top of the Deadwood at the type locality and in nearby areas of the northern Black Hills. He named the Scolithos sandstone of previous authors the Aladdin Sandstone, which he considered conformable with the underlying Deadwood Formation. Butler and others (1955) excluded the Scolithos sandstone of Jagger (1904) from the Deadwood and included it within the overlying Whitewood Formation. 
In the Williston and Powder River Basins, Ross (1957) considered the Deadwood to be as thick as $350 \mathrm{ft}(107 \mathrm{~m})$ and to contain a middle Early Ordovician trilobite fauna without an apparent break with the Late Cambrian fauna beneath; he conjectured that the Aladdin Sandstone of McCoy was part of the Deadwood Formation of subsurface usage. Carlson (1958) abandoned the name Aladdin Sandstone and included the Scolithus sandstone in the Deadwood, as did Fuller (1961).

Mickelson and Kulik (1963) divided the Deadwood Formation of the northern Black Hills area into four lithologically distinct members. The basal member is massive buff sandstone and conglomerate that locally contains burrowed micaceous siltstone and sandstone, laminated sandstone and siltstone pebble conglomerate, and thin beds of calcarenite. Glauconite is present in some beds. The second member is mainly shale, limestone, and limestone pebble conglomerate. Glauconitic beds also are present in this member. The third member is red and red-brown laminated sandstone and siltstone, pebble conglomerate, massive sandstone, and burrowed sandstone. At the top of the member is a limestone and limestone pebble conglomerate unit. A Lower Ordovician sandstone (the Scolithus sandstone) is the fourth Deadwood unit (Mickelson and Kulik, 1963); it conformably overlies the uppermost Cambrian rocks and shows that deposition was continuous through Canadian time (Gries and Tullis, 1955).

Collier and Cathcart (1922) extended the name Deadwood Formation into the Little Rocky Mountains area. They described the Deadwood as thin-bedded limestone, shale, sandstone, and intraformational conglomerate $800 \mathrm{ft}$ (244 $\mathrm{m})$ thick, lying below the Bighorn Dolomite. KnechteI and others (1944) did not use the name Deadwood in the Little Rocky Mountains and substituted the names (in ascending order) Flathead Sandstone, an unnamed principal unit, and Dry Creek Shale. Knechtel (1956) also did not use the name Deadwood in the Little Rocky Mountains and substituted the names Flathead Sandstone and Emerson Formation. He considered the Flathead and Emerson to be at least $538 \mathrm{ft}(164 \mathrm{~m})$ thick and closely comparable in age but not lithology to the Deadwood Formation as restricted by McCoy (1952).

Condra and others (1940) applied the name Deadwood to the lower $5 \mathrm{ft}(1.5 \mathrm{~m})$ of what had been part of the Guernsey Formation in the Hartville uplift. In the present report, however, these rocks are considered to be part of the Mississippian depositional sequence and not correlative to the Deadwood Formation.

The Deadwood Formation is the result of a fluctuating shoreline associated with offshore bars, lagoons, beaches, and tidal flats on an embayed coastline developed during the initial transgression in Cedaria time. A minor regression began in the Crepicephalus Zone and continued into the overlying Aphelaspis Zone. Downwarping of the depositional interface to the north resulted in the rapid transgression of shale and limestone of the Elvina Zone. Regression during Conaspis, Ptychaspis-Prosaukia, and Saukia times led to the Early Ordovician deposition of sands in the Black Hills as the sea attempted a feeble advance to the south but finally yielded to the regressive sand represented by the Scolithos beds (fig. 22). The thinning of the Deadwood to the south is not entirely due to post-Cambrian erosion but is partly the result of a progressive north-northwestward offlap of beds (Mickelson and Kulik, 1963).

In the present report the Deadwood Formation is correlated with equivalent units from western Wyoming (pl. 2) and is included in isopach maps of the Cambrian intervals (figs. 7, 14-17) in the preceding sections.

\section{Cambrian through Early Ordovician Structural Trends}

The Powder River Basin area, situated well inland of the western continental margin (fig. 1), contains basement structure that developed before or during late Precambrian rifting of that margin. Repeated reactivation of these basement trends controlled depositional patterns throughout most of the basin's history (Slack, 1981).

Middle Cambrian through Early Ordovician depositional trends in the Powder River Basin area reflect topographic and structural features inherited from a complex Precambrian tectonic history. The Cambridge arch, which occupied the Nebraska Panhandle and the southern part of western South Dakota, was a tectonically stable element of the craton adjacent to the Powder River Basin area during the Cambrian. The Cambridge arch was a northwestern extension of a highland in eastern Kansas that crossed the Transcontinental arch in central Nebraska (fig. 1). It was inherited from the Precambrian and had been reduced by subaerial erosion and was mostly covered by Early Ordovician seas (Lochman-Balk, 1960). The proto-Sweetwater trough overlaid a shear zone separating the Wyoming Archean province to the north and the Proterozoic volcanic arc succession to the south (fig. 5, Wyoming and southern Wyoming provinces). The proto-Sweetwater trough and the Uinta arch in northern Utah apparently controlled Cambrian through Early Ordovician deposition in the Powder River Basin area more strongly than did the Transcontinental arch.

Most of the structural features that were active during the Cambrian and Early Ordovician are oriented northwest-southeast (Brown and others, 1984) (fig. 18). The Cambrian section generally thins from east to west in the basin area. One exception to this general trend is an area of thinning in the central part of the study area extending from Musselshell to Powder River Counties, Montana, that Brown and other (1984) interpreted as the result of 


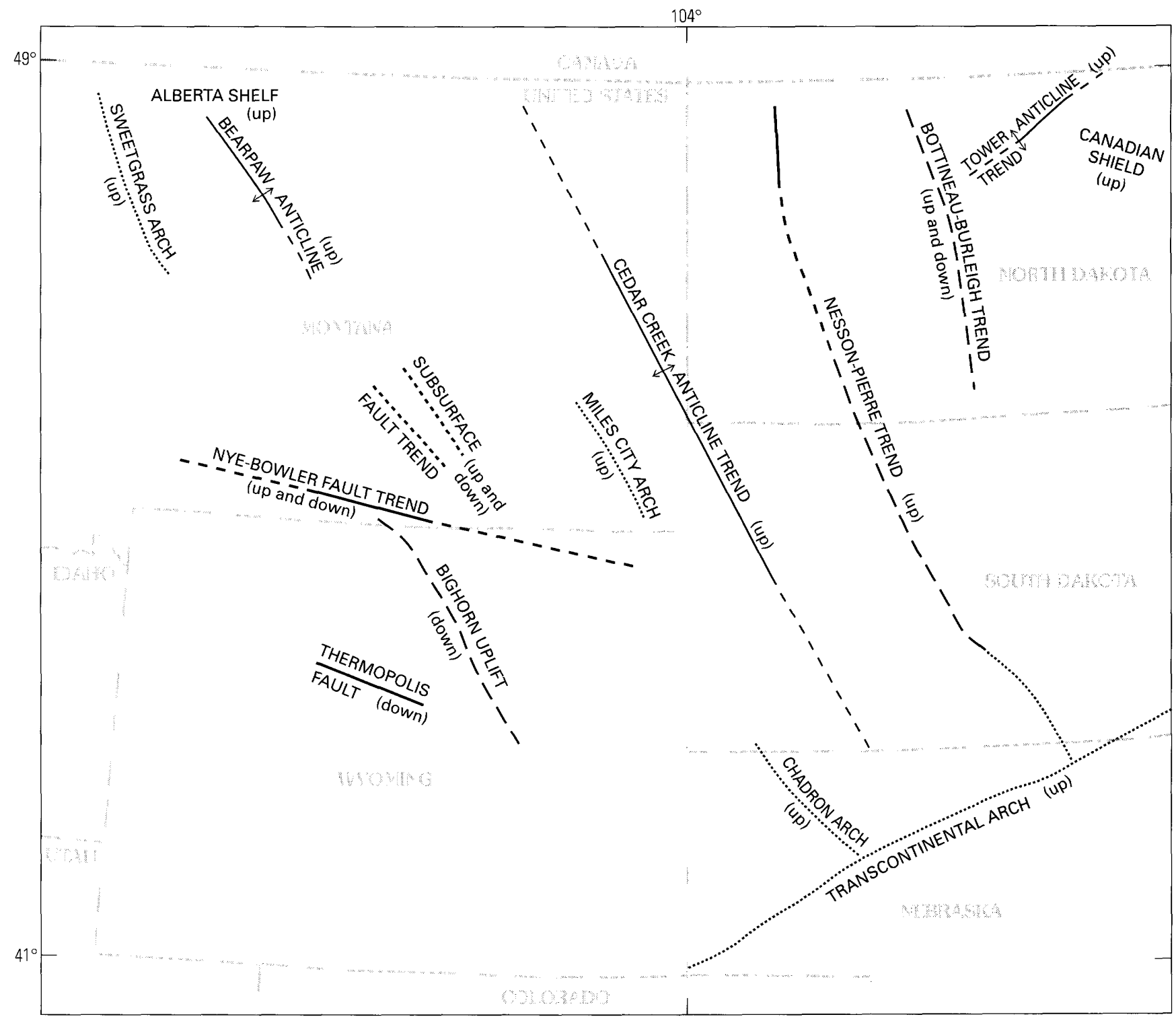

EXPLANATION
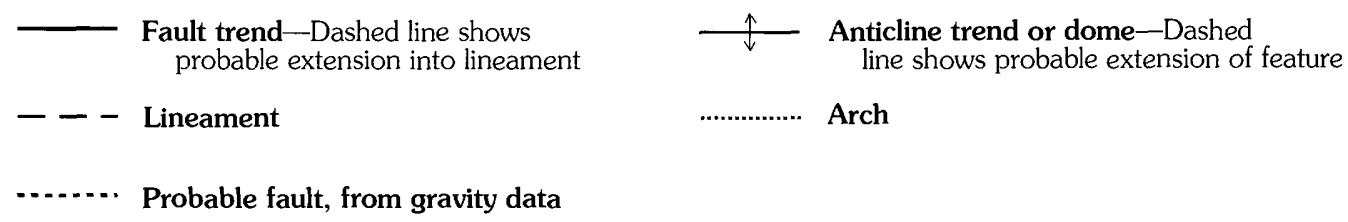

Arch

Figure 18. Paleostructural trends of stratigraphic sequence one (Cambrian and Lower Ordovician) in the northern Great Plains. Modified from Brown and others (1984).

movement on the Bearpaw anticline and two parallel faults inferred from gravity data. A second area of thinning, in Fallon and Carter Counties, Montana, and Harding County, South Dakota, is bounded on the west by the Black Hills uplift-Miles City arch trend and on the east by the Cedar Creek anticline. These trends also show on the isopach maps of the total Cambrian (fig. 7) and the
Flathead Sandstone (fig. 14). The proto-Sweetwater trough (fig. 1), a structural trough at the southern end of the basin in Fremont and Natrona Counties, Wyoming, is present on the isopach map of the Flathead Sandstone. The thick section of the Flathead Sandstone within the trough suggests that the trough controlled not only preservation but also deposition of the Cambrian section 
(fig. 14). Like the southeastward-thinning succession in the Black Hills (Mickelson and Kulik, 1963), the eastward thinning of the Cambrian in the trough probably records depositional onlap.

Seismic reflection profiling defines Middle to Late Cambrian normal faults within the Powder River Basin (McMillen, 1989). The faults form curvilinear grabens trending east-west to northwest-southeast in the southern part of the basin and a linear east-west trend in the northern part. These graben-bounding faults die out upsection, and east-west-oriented normal faults cut reflectors near the top of the Cambrian. The faults record Middle to latest Cambrian northeast-southwest extension or east-west leftlateral transtension with the Powder River Basin (McMillen, 1989).

Active structures also affected the lithofacies of the stratigraphic units (fig. 11). East of the Cedar Creek anticline and north of the Kaycee structural trend, the Cambrian through Lower Ordovician section is dominantly sandstone and lesser shale or carbonate rocks (Brown and others, 1984); west of the Cedar Creek anticline and north of the Kaycee structural trend, carbonate rocks are an important part of the sequence and no one rock type makes up more than 50 percent of the section. The Transcontinental arch served as a source area for sand in the Deadwood Formation in the eastern Powder River Basin area. Carbonate, shaly carbonate, and sandy carbonate present locally between the southern ends of the Cedar Creek anticline and the Nesson-Pierre structural trend suggest structural control of deposition (Brown and others, 1984).

A regional unconformity caps the Cambrian to Lower Ordovician sequence and truncates rocks as young as Early Ordovician in the Black Hills and adjacent parts of the Williston Basin. The sequence is missing in much of the southern basin area due to post-Early Ordovician erosion. The erosional unconformity cuts progressively older rocks from east to west and from north to south within the Powder River Basin and adjacent areas.

\section{STRATIGRAPHIC SEQUENCE TWO-MIDDLE ORDOVICIAN THROUGH SILURIAN ROCKS}

Stratigraphic sequence two includes Middle Ordovician through Silurian rocks in the Powder River Basin area (figs. 19, 20). Middle Ordovician rocks are important petroleum reservoir rocks, especially in the Williston Basin. Much of the Ordovician section and most of the Silurian section have been removed from the Powder River Basin area by pre-Late Devonian erosion.

\section{Middle Ordovician through Silurian Regional Tectonics}

Rifting along the Ouachita margin, collision along the eastern cratonic margin, and, probably, the beginning of subduction along the western Cordilleran margin dominated Middle Ordovician through Silurian sedimentation (figs. 21, 22). By Middle Ordovician time (fig. 21), collision of Northern Europe against the northeastern margin of North America from Greenland to New England had begun, initiating the Taconic orogeny (Rowley and Kidd, 1981; Smith and others, 1981; Spencer and others, 1989). Subduction may have begun along the western margin of the craton at the same time; it has been suggested that an offshore island arc and a marginal basin of trapped oceanic crust developed along the western margin during the Middle Ordovician (Irwin, 1977; Gray, 1986). As subduction beneath the arc continued, the ocean basin, which had stretched from the (present) Arctic to central Nevada (Gray, 1986), was consumed by the arc. By Late Ordovician time, if not earlier, the Powder River Basin area and the southern margin of the continent were connected across the Transcontinental arch in Nebraska and Colorado (fig. 22). The basin area changed from being part of a large basin open to the west to being part of a basin open to the southern margin of the continent.

During Ordovician time, shallow seas covered most of the craton, including most of the Canadian Shield, as shown by scattered remnants of Ordovician rocks on the shield and by downwarped strata in Hudson Bay and the Foxe Basin. In contrast to the remainder of the continent, strata of the marginal miogeoclinal belts are thicker and more complete and probably of deeper water origin, although the increase in thickness at the continental margins may be the result of more rapid subsidence and sedimentation without significant increase in water depths. Canadian cratonic margins were passive except for the transformation of the eastern margin into a Cordillerantype margin and its eventual deformation during the Taconic orogeny. Virtually complete Lower and lower Middle Ordovician sequences are present in much of the Canadian Cordilleran miogeocline and in western Newfoundland. Ordovician sequences in several parts of subarctic and arctic Canada, such as the Franklinian miogeosyncline and northwestern Baffin Island, are almost complete (Barnes and others, 1976).

Post-Silurian erosion (Gibbs, 1972) removed all but local remnants of the Interlake Formation from the Powder River Basin area (fig. 23). Silurian rocks may have covered much of the northern Great Plains and connected with Silurian facies in the miogeocline farther to the west (Brown and others, 1984, p. B9).

Clockwise rotation of North America during Middle Cambrian to Late Silurian time moved the continent southward, and the Equator passed through the Powder 


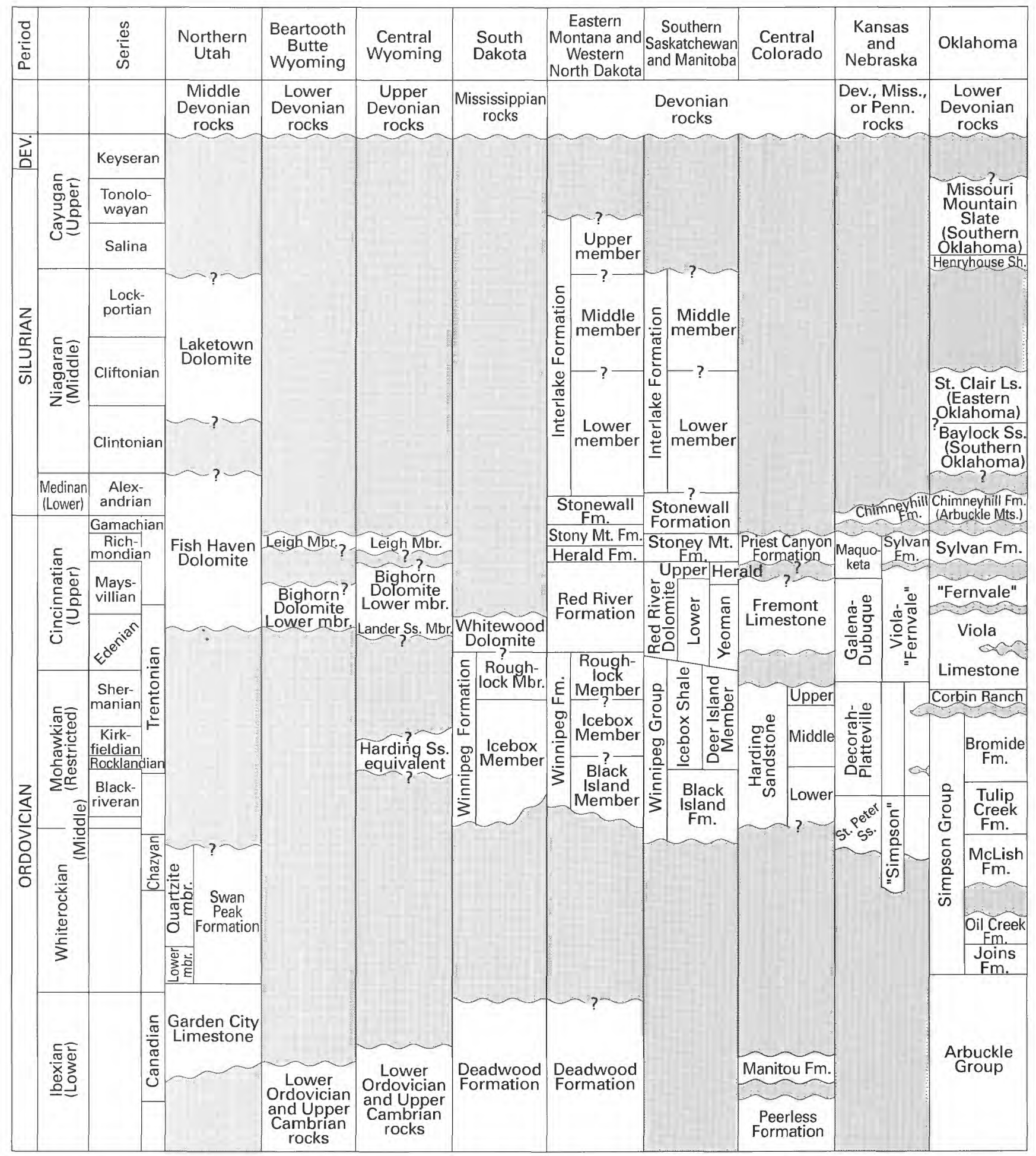

1 Member of Bighorn Dolomite

Figure 19. Detailed stratigraphic units of stratigraphic sequence two (Middle Ordovician through Silurian). Modified from Swartz and others (1942), Baillie (1951), Porter and Fuller (1959), Foster (1972), Sweet and Bergström (1976), Witzke (1980), Ballard and others (1983), Adler and others (1987), Kent and others (1988), and others.

River Basin area in Early to Middle Ordovician time (fig. 10). In early Middle Ordovician time, the Powder River Basin area was probably within a humid climatic regime within $5^{\circ}-10^{\circ}$ of the Equator, and arid-climate oolitic carbonate and marine evaporite deposition took place in Wisconsin, southeastern Iowa, Missouri, and Illinois (Witzke, 1980). Ross (1976) reconstructed plate positions of North America relative to the Equator differently from 


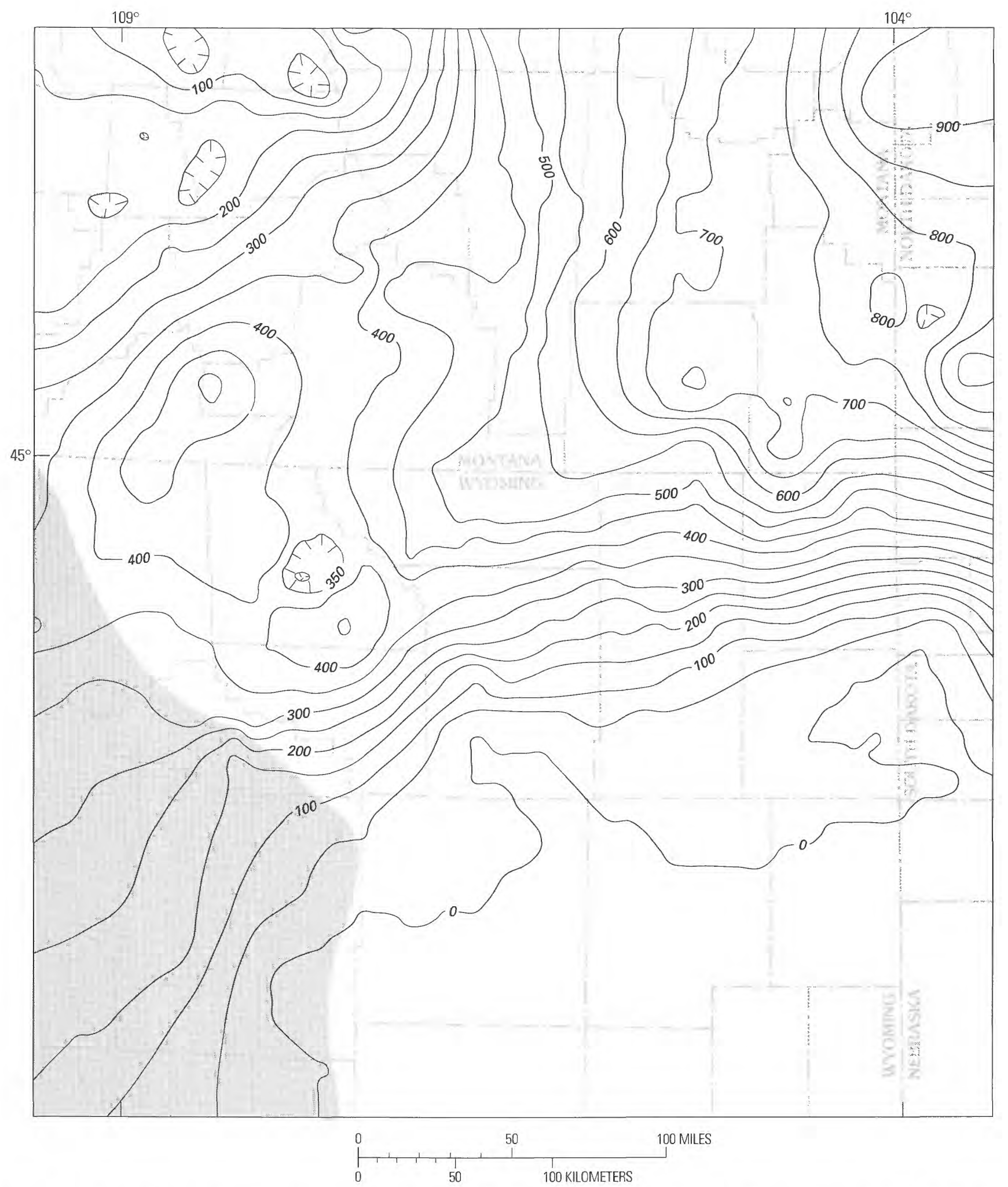

Figure 20. Isopach map of stratigraphic sequence two (Middle Ordovician through Silurian). Contour interval $50 \mathrm{ft}(15.2 \mathrm{~m})$; zero-isopach line not mapped. Based on 159 wells; gridded on an approximately 7 mi by 7 mi grid $(12 \mathrm{~km}$ by $12 \mathrm{~km})$. Screened area in southwestern part of map area is an area of very limited control. Data modified from Downey (1982). Map area shown in figure 3. 


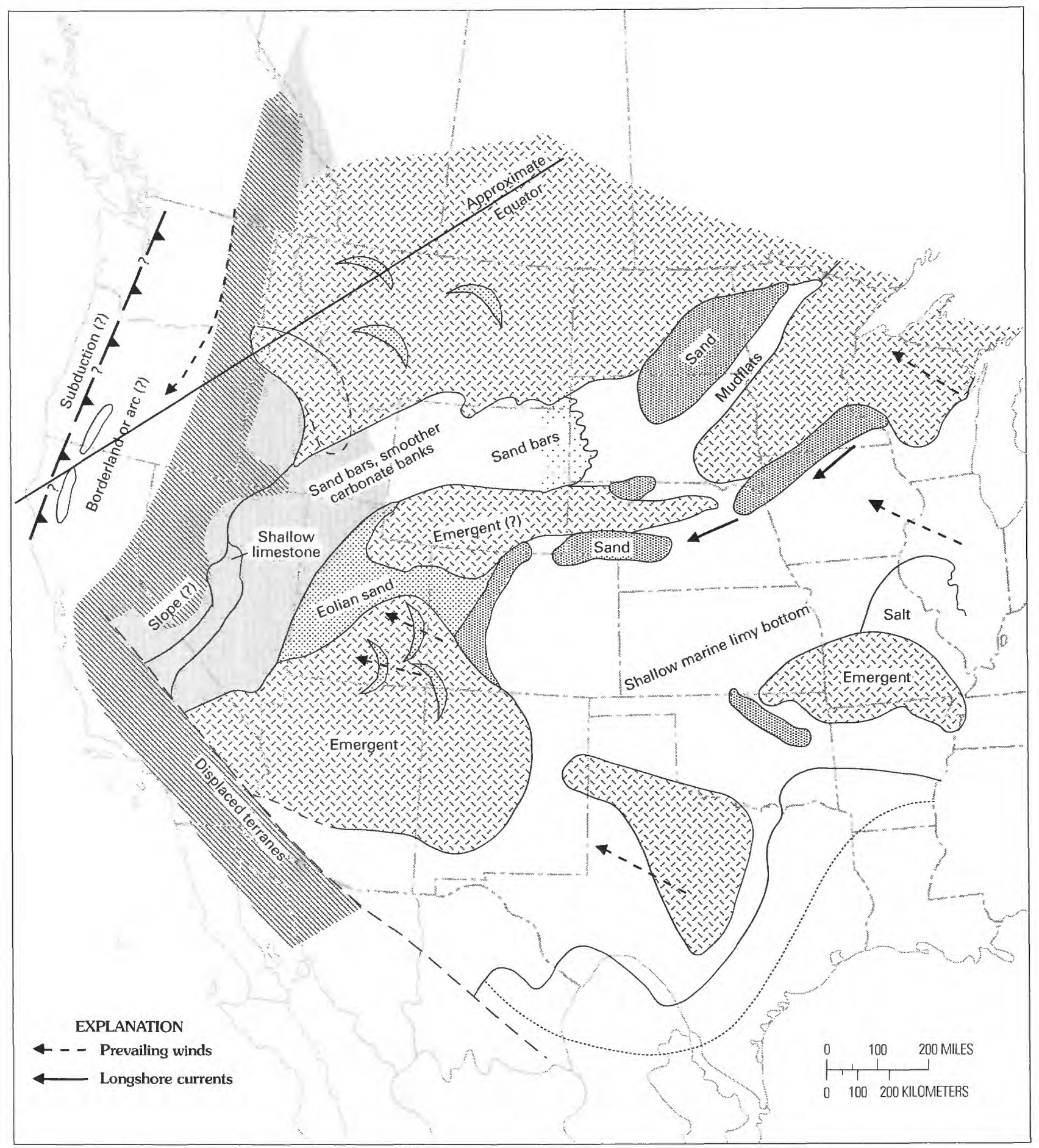

Figure 21. Paleogeography of middle part of stratigraphic sequence two (Middle Ordovician, post-Whiterockian, preCincinnatian). Random hatch pattern indicates area of nondeposition (some of these areas may be the result of later erosion and their paleogeographic relationships are uncertain); shading indicates area of uncertain paleogeography because of later compression and extension; diagonal rules show area of allochthonous continent accreted in post-Paleozoic time; stippling indicates area of sand deposition. Modified from Ross $(1976,1977)$ and others.

Witzke (1980). Ross placed the continent much farther south in the Early Ordovician and rotated it counterclockwise through the rest of the period. By mid-Late Ordovician time (fig. 22), the climate of the northern Great Plains was within an arid climatic belt, as shown by sabkha deposition in the Williston Basin (Roehl, 1967; Carroll, 1979). The Ozark dome was a distinct feature before Middle Ordovician time and also may have supplied clay 


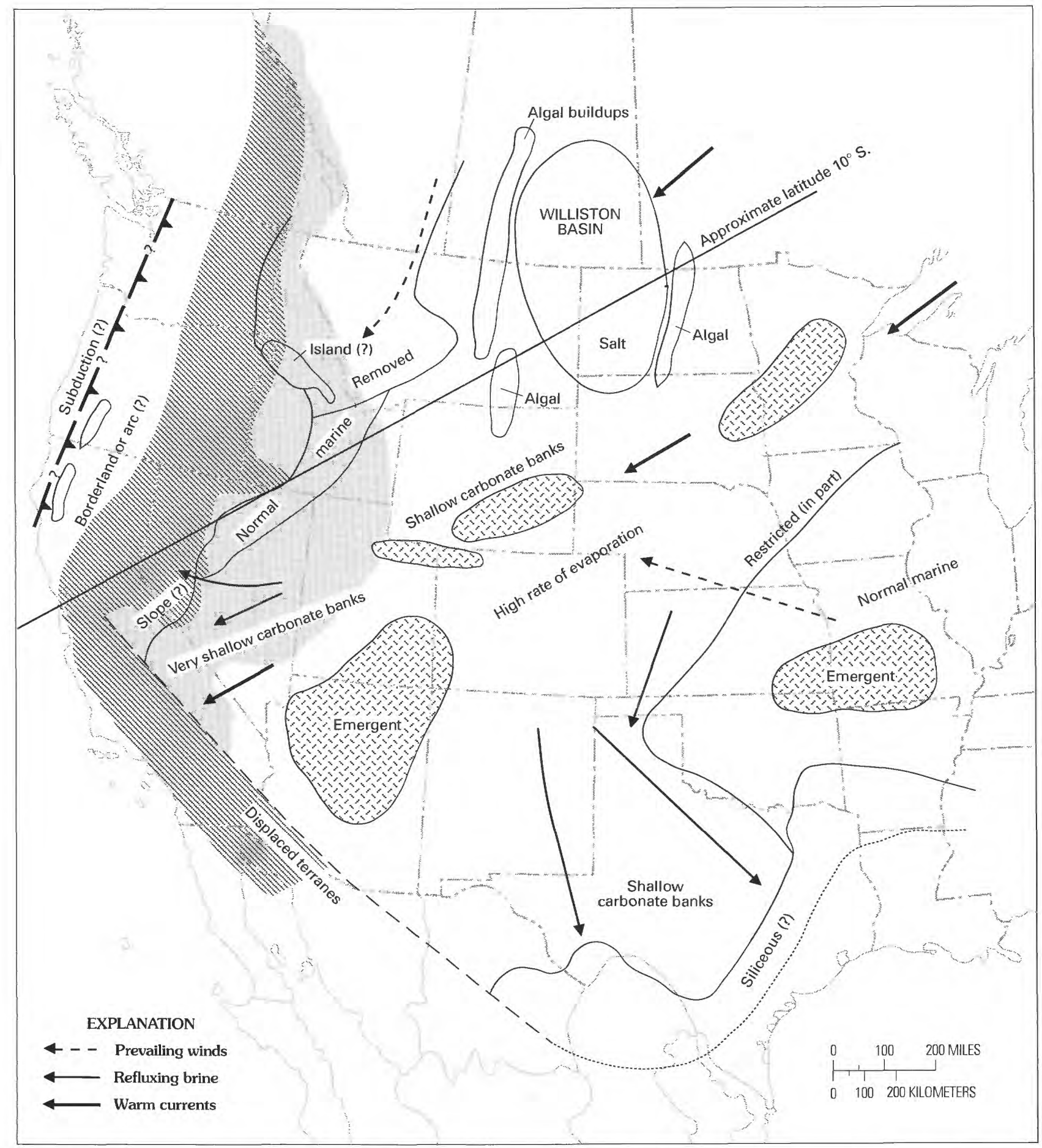

Figure 22. Paleogeography of mid-late part of stratigraphic sequence two (Late Ordovician, Cincinnatian). Random hatch pattern indicates area of nondeposition (some of these areas may be the result of later erosion and their paleogeographic relationships are uncertain); shading indicates area of uncertain paleogeography because of later compression and extension; diagonal rules show area of allochthonous continent accreted in post-Paleozoic time. Modified from Ross $(1976,1977)$ and others.

sediments to the area, but the source areas for the limited amounts of argillaceous material in Middle Ordovician carbonate rocks of the northern Great Plains and Illinois Basin areas are not easily identified (Witzke, 1980).
Late Ordovician (Edenian to Maysvillian) (fig. 21) phosphate at many localities in Indiana, Missouri, Oklahoma, Arkansas, northern Michigan, Kentucky, the Cincinnati arch region, central Tennessee, and adjacent to the 


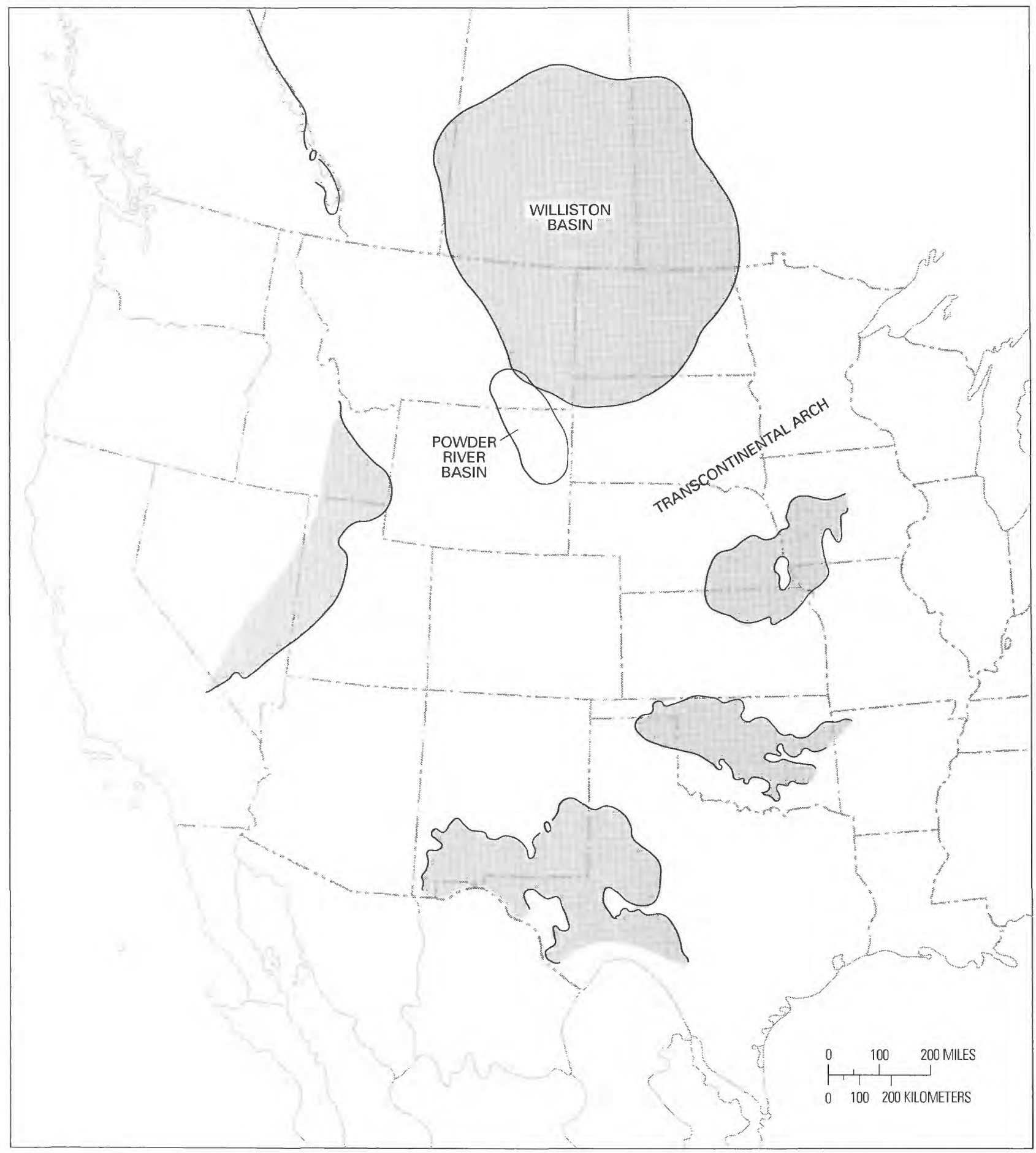

Figure 23. Areas of known Silurian rocks (upper part of stratigraphic sequence two). Modified from Cook and Bally (1975).

Appalachian Basin is interpreted as resulting from upwelling of deep, cold, nutrient-rich waters onto the shallow carbonate shelf of the Ouachita miogeocline (Witzke, 1980; Brown and others, 1984, p. 227). Edenian to mid-Maysvillian time was a period of transgression (fig. 21) (the Maquoketa sea of Gray, 1972), although minor regressive events probably interrupted the general transgression (Witzke, 1980, p. 10). The transgression gradually inundated clastic source areas of the Transcontinental arch and related structures, caused a decrease in clastic detritus, and allowed a continuous sheet of carbonate rocks to develop across the western United States. 
A mid-Maysvillian regression ended the Edenian through mid-Maysvillian transgression. Late Cincinnatian time (latest Maysvillian and Richmondian) (fig. 22) marked the appearance of the Queenston delta in New York, significant amounts of shale in Iowa, Minnesota, Illinois, Kansas, Nebraska, and Oklahoma, and minor amounts of shale and cyclic evaporite in the Williston Basin. Shale deposition over broad areas of the Midcontinent has been interpreted as the result of emergence of major clastic source areas, probably along the Transcontinental arch in South Dakota and Minnesota (Ireland, 1966, p. 35; Witzke, 1980, p. 13). Also inferred are a mild initial stage of uplift of the Central Kansas uplift (Lee, 1957, p. 46) and uplift in the Ozark uplift area. All of these uplifts were probably related to epeirogenic movements (Witzke, 1980). Throughout most of the eastern midcontinent the clastic sequence is conformable with the underlying carbonate sequence. The combination of oxidized shale and organic-rich phosphatic shale resulted from anoxia associated with high phosphate waters of the Maquoketa sea. The top of the Ordovician is characterized by redbeds, intermixed with carbonate, ironstone, or both, adjacent to the Transcontinental arch.

Portions of the Transcontinental arch may have been emergent at times during the Ordovician Period, and a shaly continental slope and carbonate shelf was south of the arch. The Salina Basin of eastern Kansas and Nebraska and the Forest City Basin in Iowa, Missouri, and northeastern Kansas record a succession similar to that in the area of the northern Great Plains and Williston Basin through the Upper Ordovician (upper TrentonianRichmondian) and also preserve a thin Silurian section (Cook and Bally, 1975). During the Ordovician, Ouachita sedimentation was dominated by dark graptolitic muds that represent turbidites transported from the shelf area to the north. Silurian rocks include a shaly flysch that was derived either from a large land mass east of the Ouachita trough or from an arc terrane to the south (Morris, 1974). Over most of the Ouachita area, however, Silurian rocks include shale and thin turbidite of cratonic origin, probably derived from the craton to the north. The Upper Silurian, Devonian, and lowermost Mississippian siliceous succession is interpreted to represent the closing of the Appalachian seaway and an influx of nutrient-rich, deep-marine water upwelling into the Ouachita trough (Morris, 1974).

The Williston Basin was the major structural feature of the northern Great Plains during Middle Ordovician time (figs. 10, 21). During late Middle Ordovician time, and probably extending into early Late Ordovician time (fig. 22), the Wyoming arch, near the position of the presentday Wasatch hinge line (fig. 5), may have been emergent and separated the Powder River Basin area from the Cordilleran miogeocline. Areas on the Transcontinental arch were positive well into Middle Ordovician time, and small islands may have been source regions through most of Middle Ordovician time. Distant locations on the Precambrian shield or highlands associated with the Taconic orogenic belt were additional terrigenous sources.

During Middle and Late Ordovician time, the northern Great Plains and central Rocky Mountain region maintained a connection to the eastern interior in at least two places (Fuller, 1961) (figs. 10, 21, 22, 24): (1) across the Transcontinental arch through the Nebraska sag, which connected the Williston Basin with the Salina Basin in eastern Nebraska, and (2) through the Colorado extension of the Anadarko Basin (represented by the Harding Sandstone). Transgression ultimately buried all or most of the clastic source areas on the Transcontinental arch. Fossils preserved in diatremes near the Colorado-Wyoming State line suggest that deposition was continuous from the beginning of Middle Ordovician through Silurian time (Chronic and others, 1969; Kent, 1972, p. 57)

During Late Ordovician time (fig. 22), the seas apparently breached the Wyoming arch (fig. 5) and a link was established in the Powder River Basin area between the Williston Basin and the western Cordilleran miogeocline (Foster, 1972) (fig. 24). Deposition lapped onto the southwestward end of the Transcontinental arch from all directions. Maximum transgression of the interior sea probably occurred in the Middle Silurian, contemporaneous with volcanism in the inferred island arc system to the west (Roehl, 1967) as the supercontinent of Laurasia began form. Uplift of the Transcontinental arch at the close of the depositional interval is mostly responsible for the present distribution of Ordovician rocks along the arch. The Transcontinental arch was probably not as formidable a barrier during most of Ordovician-Early Devonian time as it was later, and it apparently had little effect on the south to north transgression.

\section{Paleobiological Controls on Sedimentation}

The Upper Ordovician and Silurian of the Williston Basin represents a change from vast sheets of open-marine carbonate deposition to lime mud-sabkha cyclic deposition (Roehl, 1967; Wilson, 1975, p. 301) (fig. 22). By Middle Silurian time, shallow seas producing marine carbonate rocks inundated almost the entire continent, and patches of mounds and ecological reefs of algae, corals, and stromatoporoids generally rimmed the craton and lapped onto the eastern side of it in a wide belt now exposed in Indiana, Michigan, and Illinois (Wilson, 1975, p. 105) (fig. 23). The Cordilleran miogeocline contains a shelf margin of Silurian age in central Nevada and in the northern Canadian Rockies. Barrier reef rims, however, are not known from these areas. Facies changes are sharp, from fossiliferous carbonate to graptolite-bearing, dark or 


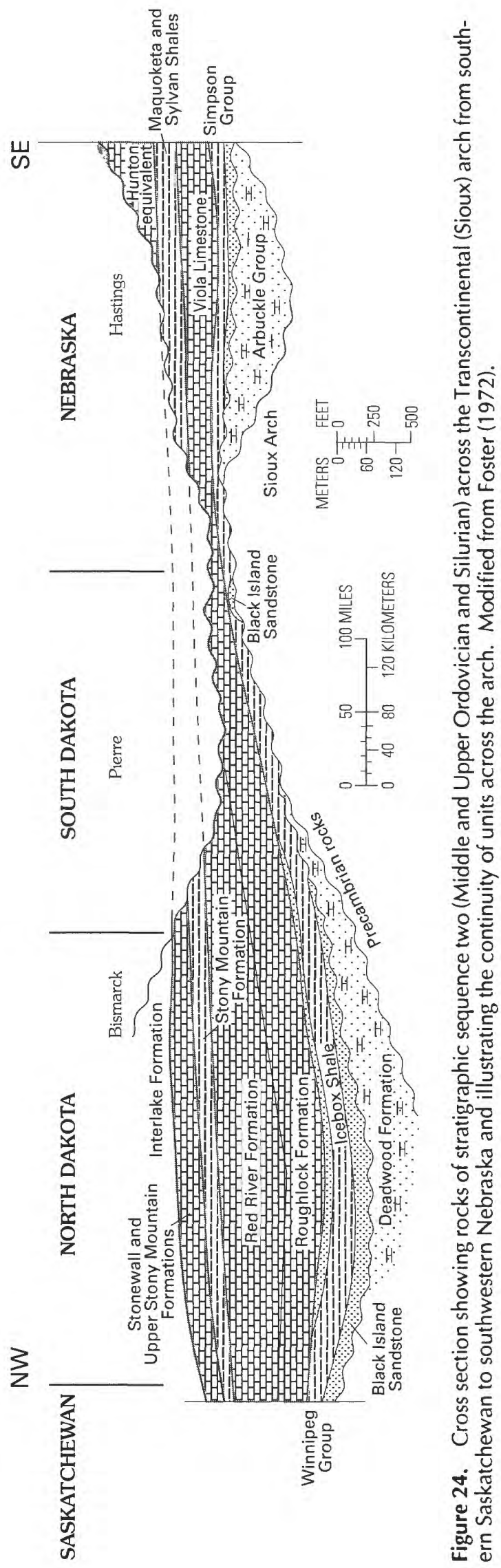


reddish shaly sediment. Turbidite and slump deposits suggest steep slopes, but rocks of the shelf margin are so thoroughly dolomitized that their real character is unknown. A belt of limestone borders the dolomitized craton in most places, but the fauna is the same in this belt as within the craton (Wilson, 1975).

In pre-middle Paleozoic time, tidal-flat construction had been the dominant process; carbonate was added to the cratonic shelves and carbonate bank development was restricted to passive margins. Before the Middle Ordovician, however, plate collisions destroyed many continental margins and major intracratonic downwarps began to develop (fig. 21). Changes in carbonate depositional environments in the Middle Ordovician-the ability of organisms to form a definite ecological association, to secrete carbonate in their tissues at a rapid rate, and to proliferate and diversify-were a significant event in Earth history, almost as dramatic as the first appearance of calcareous hard parts in the Cambrian and the biological changes at the end of the Paleozoic (Wilson, 1975). Organic construction began to be an important process for the deposition of carbonate, mostly due to the appearance of large sessile-benthic organisms such as corals and stromatoporoids (James, 1983). The vast Middle to Upper Ordovician carbonate sheet records development of carbonate banks in intracratonic basins (James, 1983) and has a more or less uniform normal marine fauna and considerable consistency in sedimentary facies. Facies did vary locally: marine environments were more restricted over slight paleohighs; dark, laminated, shaly limestone accumulated in shallow mudfilled depressions on the shelf; and narrow linear facies belts formed close to barriers at the shelf margin. Generally, however, facies patterns on the shallow shelves are broad and irregular (Wilson and Jordan, 1983, p. 300).

\section{Stratigraphic Units of Sequence Two}

Stratigraphic sequence two (Middle Ordovician to Silurian) (figs. 2, 19, 20, pls. 1,2) includes, in ascending order, (1) the Middle Ordovician Winnipeg Formation; (2) the overlying Red River Formation and Whitewood Dolomite, and the Bighorn Dolomite and the partly equivalent Stony Mountain Formation in the eastern Powder River Basin; and (3) rocks of the Silurian or Upper Ordovician and Silurian Interlake Formation in the northeastern part of the study area. For this report, I consider the Bighorn Dolomite of the western Powder River Basin to be in part the southwestern shelf equivalent of the Red River Formation or Whitewood Dolomite of the Williston Basin and the northeastern Powder River Basin. In the strict sense, however, the Red River may include rocks both older and younger than those of the Bighorn (Witzke, 1980).
In the Williston Basin, the Ordovician-Silurian boundary may be within the Stonewall Formation (Ballard and others, 1983), which is between the Stony Mountain Formation and the Interlake Formation (Baillie, 1950) (figs. 2, 19). Sandberg (1967) included the Stonewall Formation within the Interlake Formation and considered the Interlake to be of Late Ordovician and Silurian age. In the Powder River Basin area stratigraphic sequence two has a combined thickness that ranges from a zero edge in the central Powder River Basin to about 1,500 ft $(457 \mathrm{~m})$ in the western Williston Basin (pls. 1, 2). The sequence is almost 1,100 $\mathrm{ft}(335 \mathrm{~m})$ thick in the Big Snowy trough.

The base of the Middle Ordovician sequence in the Black Hills is younger than that in the Williston Basin of Saskatchewan and Manitoba, and the base of the sequence in the Bighorn Mountains is younger still (fig. 10). The basal Middle Ordovician in central Colorado is younger than that in Kansas and Nebraska but older than that in central Wyoming; these relations suggest that transgression progressed from south to north and from east to west crossing the Transcontinental arch and lapping up onto the Wyoming arch (fig. 5), which was near the position of the present-day Wasatch hinge line. In the Williston Basin, the sequence also is transgressive from south to north and from east to west. The transgression may also have spread eastward and westward from the Nebraska sag (Witzke, 1980), a trough that formed across the Transcontinental arch near the point at which the Missouri River now crosses the South Dakota-Nebraska State line (Foster, 1972), and from the Colorado extension of the Oklahoma Anadarko Basin (Witzke, 1980) (figs. 10, 22).

The Stony Mountain Formation and the succeeding Silurian Interlake Formation (figs. 2, 19) represent sabkha deposition within the Williston Basin (fig. 22). Micritic texture is dominant, and packstone or grainstone commonly is present only as thin channel and natural levee deposits. The cycles generally begin with open-marine or partly restricted carbonate rocks, followed by a tidal-flat sequence of algal stromatolites marking the level of high tide. The final depositional events within the sequence are climate controlled: in arid climates a sabkha anhydrite sequence caps the cycle, and in tropical climates crusts and minor caliche surfaces form at the end of the cycle. Sharp lithologic contact is at the top, but evidence of downcutting channels or much prolonged or intense action of meteoric waters is lacking. Dolomitization of such cyclic sequences is common (Wilson, 1975). Evaporite deposits at the top of the Stony Mountain Formation suggest an arid depositional environment.

Patterson (1961), Foster (1972), Witzke (1980), Ross and others (1982), Peterson (1984), and Peterson and MacCary (1987) provided generalized summaries of Ordovician stratigraphy. Carlson and Anderson (1965) summarized stratigraphy of the Winnipeg, and Dow (1974) discussed petroleum source beds within the 
Winnipeg. Ross (1957) discussed the biostratigraphy and interregional correlations of the Bighorn. Kohm and Louden (1978) and Longman and others (1983) discussed petroleum production from the Red River in the Williston Basin. Porter and Fuller (1959), Carlson and Eastwood (1962), Gibbs (1972), and Peterson and MacCary (1987) summarized stratigraphy of the Interlake in the Williston Basin and adjacent areas, and Sandberg and Mapel (1967) mapped the southwestern limits of the Interlake in the Powder River Basin and adjacent areas.

\section{Winnipeg Formation}

The Winnipeg Formation (Champlainian) (figs. 2, 19, 25) represents the initial clastic deposits of the Middle Ordovician-Silurian sedimentary sequence (fig. 10). Dowling (1900) first named the Winnipeg, and Erickson (1954) introduced the name into South Dakota to replace the name St. Peter Sandstone. In this report, the Winnipeg is assigned a formation rank, although in the Williston Basin where it is divisible into formations it is generally assigned a group rank. In the Black Hills and throughout most of the Williston Basin, the Winnipeg is unconformable on the Upper Cambrian-Lower Ordovician succession, except in eastern North Dakota where it rests directly on the Precambrian basement (pls. 1, 2). In the Bighorn Mountains, the Winnipeg equivalent is primarily sandstone less than $50 \mathrm{ft}(15 \mathrm{~m})$ thick. In central Colorado, the base of the sequence is the Harding Sandstone, and equivalent strata in central Wyoming are commonly referred to as the "Harding equivalent." Where most completely developed in the Williston Basin, the Winnipeg Formation consists of three members (in ascending order), the Black Island, Icebox, and Roughlock (LeFever and others, 1987, p. 22). The Winnipeg Formation attains a maximum thickness of about $440 \mathrm{ft}(134 \mathrm{~m})$ in northwestern North Dakota near the center of the Williston Basin where it unconformably overlies the Deadwood Formation.

Although erosion has removed much of the stratigraphic record of this interval from the Powder River Basin (fig. 2), the Williston Basin provides a more complete section. Onlap of the Winnipeg onto the Wyoming arch (fig. 5) in western Wyoming was probably the result of eustatic sea-level rise modified by preexisting structural and topographic features.

In southern Manitoba, North Dakota, South Dakota, and northwestern Minnesota, the Winnipeg is predominantly shale, in part phosphatic (fig. 21). Together with minor sandstone or siltstone it represents an offshore mudstone and transitional facies (Vigrass, 1977; Witzke, 1980). In South Dakota, Manitoba, and southeastern Saskatchewan, the lower and basal upper parts of the Winnipeg contain oolitic ironstone (hematite and goethite) pellets, both disseminated in shale and in discontinuous ironstone bands that may represent an oxidized phase of oolitic pyrite having a similar distribution (Witzke, 1980). Hematite and goethite ironstone also crops out in the Black Hills. The upper part of the Winnipeg Formation consists of the Icebox and Roughlock Members, which were deposited during a regional expansion of the mudstone facies. Marginal onlap of sandstone and offshore green shale, in part sandy or shaly and commonly containing abundant phosphate grains or pellets, characterizes the mudstone facies. Sandstone and siltstone bodies may be present in the offshore Winnipeg, especially the uppermost Winnipeg (Witzke, 1980).

The Winnipeg (and the partly equivalent St. Peter Sandstone and McLish Formation) may be a diachronous sheet of clastic deposits that, following Whiterockian erosion (fig. 10), lapped onto the margin of the Transcontinental arch (Witzke, 1980) and a western arch roughly in the position of the Wyoming arch (possibly the same trend as the "central Montana structural trend" of Brown and others, 1984). The sands of the Winnipeg were derived primarily from a western source area (Foster, 1958) (fig. 21 ), whereas farther to the west much of the sand of the Middle Ordovician throughout the Cordilleran miogeocline was derived from erosion of Cambrian sandstone in northern Alberta (Ketner, 1968). The Cambrian of Alberta also may have been a source for sands in the Winnipeg (Peterson, 1984). The varying age of the Cambrian beneath the Middle Ordovician succession on the Wyoming shelf suggests that local sources of sand were also available (Foster, 1972; Lochman-Balk, 1972). In western Wyoming, erosion removed rocks as old as late Middle Cambrian along the trend of the Wyoming arch before Middle Ordovician deposition began. In the Williston Basin, the greatest influx of sand was from the Cambrian and Ordovician Deadwood terrane to the west and from Precambrian terranes to the north. The Transcontinental arch supplied little sand except for the Carman Quartzite offshore "bar" in northeastern North Dakota and southern Manitoba (Vigrass, 1977; Witzke, 1980).

In the northern Bighorn Mountains, two sandstone units overlie the Lower Ordovician and underlie the Late Ordovician carbonate sequence: the Middle Ordovician Harding Sandstone equivalent (Kirk, 1930) and the Lander Sandstone Member of the Bighorn Dolomite (Kirk, 1930; Miller, 1930) (figs. 2, 19). The two units have a combined thickness of about $40 \mathrm{ft}(12 \mathrm{~m})$. The base of the Harding equivalent is an erosional unconformity and contains rock fragments of the underlying Cambrian in its lower part. Above the base, the Harding is more argillaceous, and a clean, yellowish sandstone containing fish fragments caps the unit. Red and white mottling marks the top of the Harding equivalent below the unconformity with the Lander. The Lander is 6-12 ft $(1.8-3.7 \mathrm{~m})$ thick and is mineralogically similar to the underlying Harding equivalent. The 


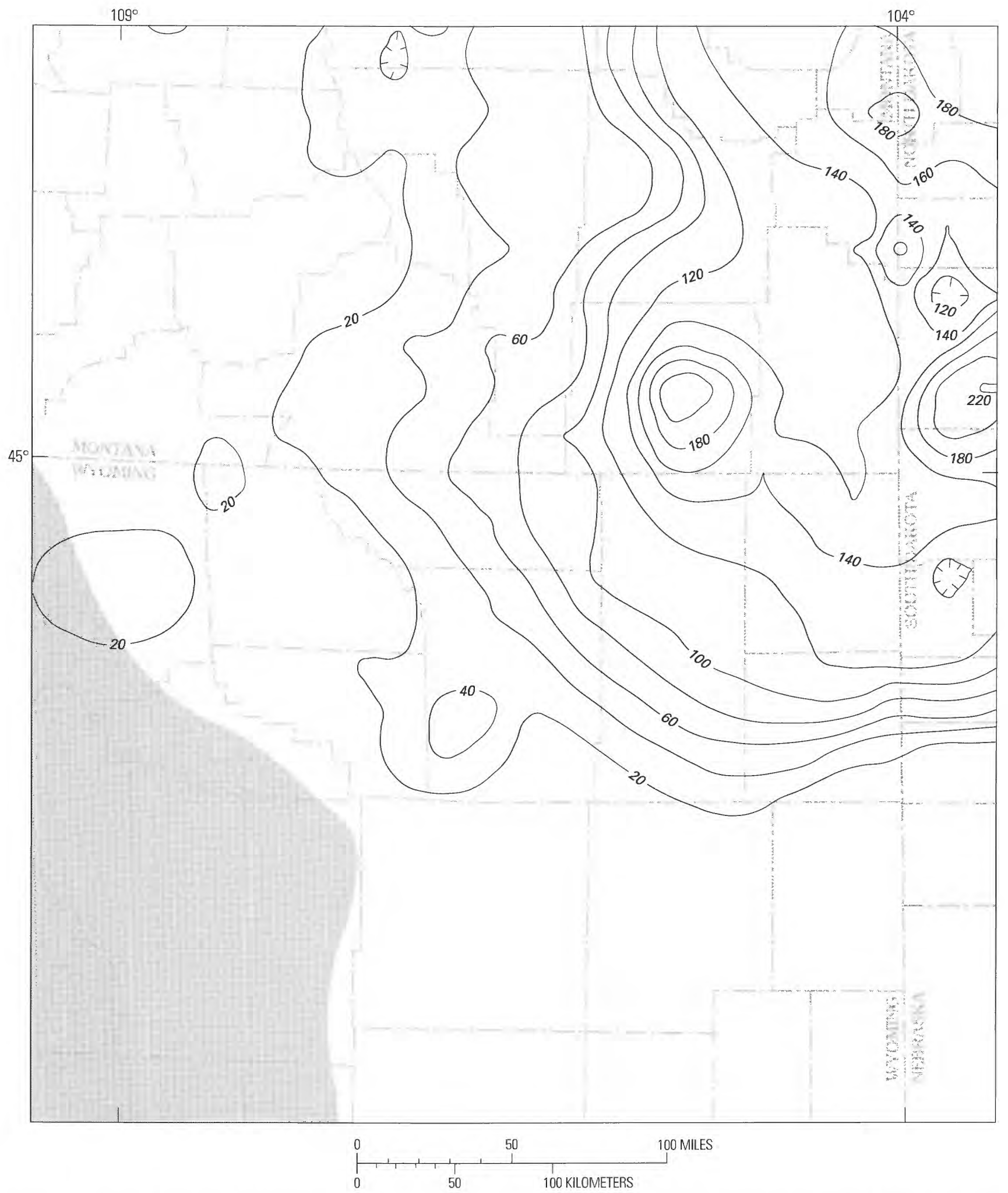

Figure 25. Isopach map of the Winnipeg Formation and equivalent rocks of sedimentary sequence two (lower Middle Ordovician). Contour interval $20 \mathrm{ft}(6.1 \mathrm{~m})$; zero-isopach line not mapped. Based on 194 wells; gridded on an approximately 15 mi by $15 \mathrm{mi}$ grid $(24 \mathrm{~km}$ by $24 \mathrm{~km}$ ). Screened area in the southwestern part of the map area is an area of very limited control. The initial clastic deposits of sequence two (Winnipeg and equivalents) are generally absent in the southern part of the study area and are present in the western part of the study area only as isolated remnants of the Harding Sandstone equivalent. Data modified from Downey (1982). Map area shown in figure 3. 
Lander grades upward into the overlying Upper Ordovician massive dolomite part of the Bighorn Dolomite.

Southward, in Colorado, the Harding Sandstone is similar in thickness to much of the Winnipeg in the Williston Basin but differs by containing more sandstone than shale, suggesting proximity to clastic sources (Sweet, 1955). A lower sandstone, middle shale, and upper sandstone analogous to the Black Island-Icebox-Roughlock of the Winnipeg in North Dakota (Carlson, 1960) make up the Harding in Colorado.

To the north, in the Canadian part of the Williston Basin, the Winnipeg Formation thins from about $200 \mathrm{ft}$ $(61 \mathrm{~m})$ near the Canada-United States border to zero just north of Lake Winnipeg (McCabe and Barchyn, 1982). In Manitoba the Winnipeg Formation has two members: a lower sandstone member and an upper unit of green, waxy shale and interbedded sandstone.

Sweet and others (1971) interpreted the unconformity between the Harding equivalent and the lower part of the Bighorn as representing a mid-Kirkfieldian to midMaysvillian unconformity (shown as early Edenian on fig. 1 of Witzke, 1980). Sweet and Bergström (1976) dated the Harding equivalent as late Blackriverian through Rocklandian and possibly early Kirkfieldian, based on conodont biostratigraphy.

To the west of the Powder River Basin, in the miogeocline in northern Utah and southeastern Idaho, Middle Ordovician sedimentation was apparently conformable, or almost so, with the underlying Lower Ordovician. The Swan Peak Formation overlies the uppermost beds of the Garden City Limestone, which are thought to be lowermost Middle Ordovician. The Swan Peak probably is a littoral facies of the Garden City Limestone, which it replaced progressively from east to west as the Middle Ordovician sea withdrew to the Cordilleran miogeocline. The Swan Peak lies on Cambrian rocks in the Wasatch Mountains north of Salt Lake City and has not been found eastward along the Uinta Mountains. It does not extend northeast into Wyoming or into northeastern Bonneville County, Idaho, but it is $650 \mathrm{ft}(198 \mathrm{~m})$ thick in the Chesterfield Range in northeastern Bannock County, Idaho (Williams, 1955). The Swan Peak is apparently unconformable beneath the Fish Haven Dolomite, a stratigraphic equivalent to the Bighorn Dolomite (Cook and Bally, 1975).

\section{Lower Part of the Winnipeg Formation}

The lowermost unit of the Winnipeg Formation, the Black Island Member (LeFever and others, 1987) (figs. $19,26)$, is divided into two parts. The lower part is almost entirely in the western half of North Dakota, where it is as thick as $100 \mathrm{ft}(30 \mathrm{~m})$ in the area of the Nesson anticline. The lowermost Winnipeg is mainly free of calcareous sediment except as minor carbonate cement.
A 5 -ft $(1.5 \mathrm{~m})$-thick shaly limestone is, however, in northwestern Minnesota. The lower part contains two lithofacies (LeFever and others, 1987): a redbed lithofacies and a green quartzwacke lithofacies. The redbed lithofacies is primarily dark-reddish-brown quartzarenite and lesser amounts of finely laminated dark-red and darkgreen mudstone, which, in places, is interbedded with thin lenticular fine-grained crossbedded sandstone or mudstone. The quartzarenite is commonly fine to medium grained and well sorted. It is generally massive but in some places is finely laminated. The quartzarenite beds range from about 1 to $20 \mathrm{ft}(0.3-6 \mathrm{~m})$ in thickness, are nonfossiliferous, and show no evidence of bioturbation. In places, this redbed facies is interbedded with white quartzarenite and rocks of the green quartzwacke lithofacies. The dark-red mudstone of the redbed facies contains mud cracks and red siltstone with horizontal laminations. The redbed lithofacies contains both finingupward and coarsening-upward sequences. The green quartzwacke facies of the lower part of the Black Island is characterized by poorly sorted, fine- to coarse-grained, light-greenish-gray, shaly quartzwacke. Locally, thin lenticular light-green shale alternates with the quartzwacke or with a less common well-indurated quartzarenite.

The upper part of the Black Island (LeFever and others, 1987) (figs. 19, 26) is much more widespread than the lower part. Sandstone makes up most of the upper part. The upper part is conformable with both the underlying lower part of the Black Island and the overlying Icebox Member. It is thickest $(165 \mathrm{ft}, 50 \mathrm{~m})$ in the area of the Nesson anticline and thins rapidly both east and south. Two lithofacies are within the upper part of the Black Island: a quartzarenite and a green quartzwacke. Wellrounded, fine- to medium-grained, quartz-cemented, massive quartzarenite, gradationally interbedded with lesser amounts of bioturbated quartzwacke, dominates the quartzarenite lithofacies. The green quartzwacke lithofacies is friable to moderately indurated, fine- to mediumgrained, and similar to the green quartzwacke of the lower part of the Black Island. The red quartzarenite both underlies and overlies the green quartzwacke, generally with a gradational lower contact and a sharp upper contact.

The Black Island (LeFever and others, 1987) (figs. 19, 26) may represent a terrestrial setting such as a flood plain or delta plain: quartzarenite of the redbed lithofacies represents channel and bank deposits, and mudstone represents flood-plain deposits. The green quartzwacke lithofacies may have formed by weathering of pre-existing strata of the lower part, or, more plausibly, as the initial deposits of the transgression that later deposited the quartzarenite of the upper part. The green quartzwacke within the lower part represents an intertonguing of the upper and lower parts, suggesting a facies relationship between at least part of the two units. The upper part may represent deposition in a nearshore environment in a zone 


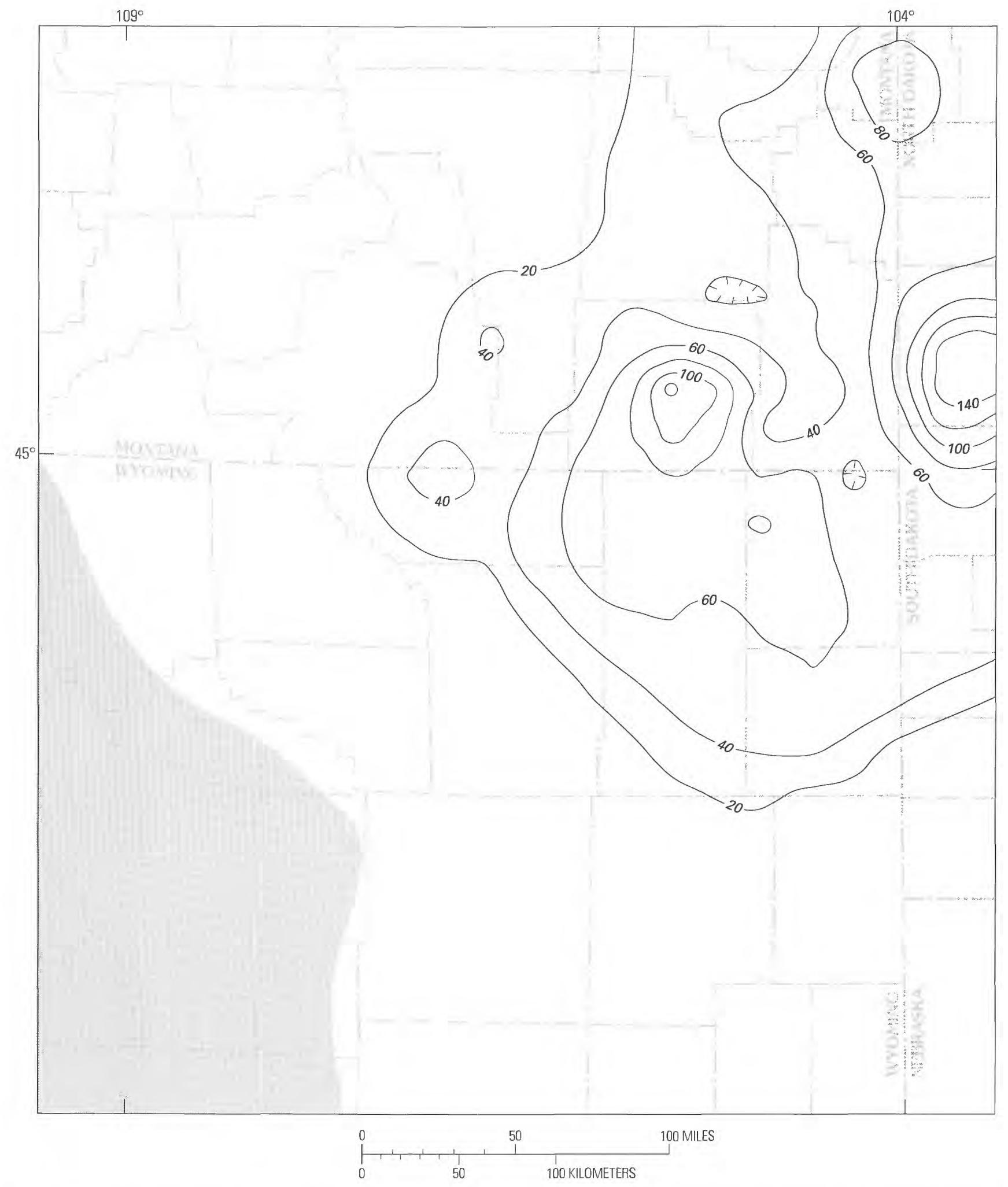

Figure 26. Isopach map of the Black Island Member of the Winnipeg Formation of stratigraphic sequence two. Contour interval $20 \mathrm{ft}(6.1 \mathrm{~m})$; zero-isopach line not mapped. Based on 131 wells; gridded on an approximately $15 \mathrm{mi}$ by $15 \mathrm{mi}$ grid (24 km by $24 \mathrm{~km})$. Screened area in the southwestern part of the map area is an area of very limited control. Map area shown in figure 3. 
between the beach and the open-marine shelf in water depths of about $30-100 \mathrm{ft}(9.1-30 \mathrm{~m})$, subject to both normal and storm-driven wave processes. Interbedding of the green quartzwacke and lithofacies of both the lower and upper parts of the Black Island suggests an environment transitional between those of the other lithofacies, such as a beach or marginal-marine environment.

\section{Upper Part of the Winnipeg Formation}

The upper part of the Winnipeg Formation consists of the Icebox and Roughlock Members (figs. 2, 19). The Icebox (LeFever and others, 1987) (fig. 27) is mostly shale and has conformable, gradational contacts with both the sandstone of the underlying Black Island and the shaly limestone of the overlying Roughlock. The Icebox is more than $150 \mathrm{ft}(46 \mathrm{~m})$ thick in the central Williston Basin. It is generally bioturbated and in some places contains distinct burrows, brachiopods, trilobite fragments, and other unidentified fossil fragments. It locally contains black phosphate nodules. Sandstone is present in at least three horizons in the Icebox as fine- to medium-grained, argillaceous, highly bioturbated quartzwacke that is, in places, crosslaminated. The contact between sandstone and the overlying shale is gradational. The maximum thickness of these sandstone horizons varies from about 30 to $60 \mathrm{ft}$ (9.1-18 m). In the western part of the Williston Basin, the shale of the Icebox is replaced by interbedded sand and shale that ultimately grade into sandstone west of about long $105^{\circ} 15^{\prime} \mathrm{W}$. (Anderson, 1982).

The Icebox (LeFever and others, 1987) may represent an offshore open-marine environment that had normal salinity and mildly oxidizing conditions. The Icebox probably was deposited in deeper water than, or at least some distance seaward from, the upper part of the Black Island. The lower sandstone of the Icebox in northwestern North Dakota may be a tongue of the upper part of the Black Island. The depositional sequence in Divide County, North Dakota, suggests that transgression was followed by regression when the nearshore sandstone of the Icebox retreated as far as northeastern North Dakota. Another transgression, recorded by the overlaying shale, followed retreat of the sea. The intertonguing of sandstone and shale suggests that at least parts of the upper unit of the Black Island are a facies of the Icebox. Offshore bar deposits also are present within the Icebox of the eastern Williston Basin, and delta deposits having a source to the south are present in southwestern North Dakota.

The Roughlock (LeFever and others, 1987) (figs. 2, 19, 28 ) is transitional between the noncalcareous shale of the underlying Icebox and the overlying carbonate rocks of the Red River Formation. Siltstone and sandstone and minor interbedded calcareous shale or arenaceous-shaly carbonate rock mark a transition zone that separates the Winnipeg from the overlying Red River (Witzke, 1980).
The Roughlock is predominantly a nodular microsparite limestone (a limestone whose carbonate-mud matrix has recrystallized to microspar; Folk, 1959, p. 32) in a matrix of argillaceous, dolomitic, fossiliferous wackestone. Fossils include brachiopods, trilobites, echinoderms, and some unidentified fossils. As much as $40 \mathrm{ft}(12 \mathrm{~m})$ of sandstone interbedded with thin shale is present in south-central North Dakota. The Roughlock thins westward from $90 \mathrm{ft}$ $(27 \mathrm{~m})$ just west of its truncated eastern edge, is about $20-30 \mathrm{ft}(6.1-9.1 \mathrm{~m})$ thick over the western third of North Dakota, and is very thin near the northwestern corner of the State. The basal Roughlock consists of interbedded argillaceous limestone and calcareous shale.

The Roughlock also may represent an offshore environment, similar to that of the Icebox (LeFever and others, 1987). During Roughlock time, however, the amount of detrital material decreased enough to permit increased carbonate production. Lobate sandstone within the Roughlock may represent deposition on a delta. The sandstones of Roughlock are similar in lithology and morphology to the sandstones of the Icebox in southwestern North Dakota, although the sandstones of the Roughlock are stratigraphically higher. The sandstones of the Icebox and Roughlock are in stratigraphic succession in part of south-central North Dakota, suggesting deposition by shifting delta distributaries.

\section{Bighorn Dolomite and Red River and Whitewood Formations}

The partial equivalents of the Bighorn Dolomite and Whitewood and Red River Formations (figs. 2, 19, 29) overlap the underlying Winnipeg Formation as a sequence of primarily clean carbonate rocks (fig. 30) that were deposited as a prograding carbonate bank across the western continental shelf (fig. 21). The Whitewood and Red River are generally conformable with the underlying Winnipeg in the eastern part of the study area, although the Bighorn may be unconformable above the Harding equivalent in the Bighorn Mountains and to the west. The Bighorn Dolomite and equivalent rocks extends farther outward along all margins of the Williston Basin than the underlying Winnipeg (figs. 25, 29). The Red RiverBighorn-Whitewood interval is more than $400 \mathrm{ft}(122 \mathrm{~m})$ thick in the northwestern Powder River Basin and more than $600 \mathrm{ft}(183 \mathrm{~m})$ thick in the central part of the Williston Basin (Peterson, 1984). The sequence feathers to an erosional zero-edge across the Powder River Basin along an east-west to northeast-southwest line extending from the northern Black Hills to the southern Bighorn Mountains. In the center of the Williston Basin, the Red River Formation contains a lower unit of fragmental limestone and an upper unit consisting of three evaporite cycles of fragmental limestone and anhydrite (Porter and Fuller, 1964; Carroll, 1979; Witzke, 1980; Peterson, 1984). 


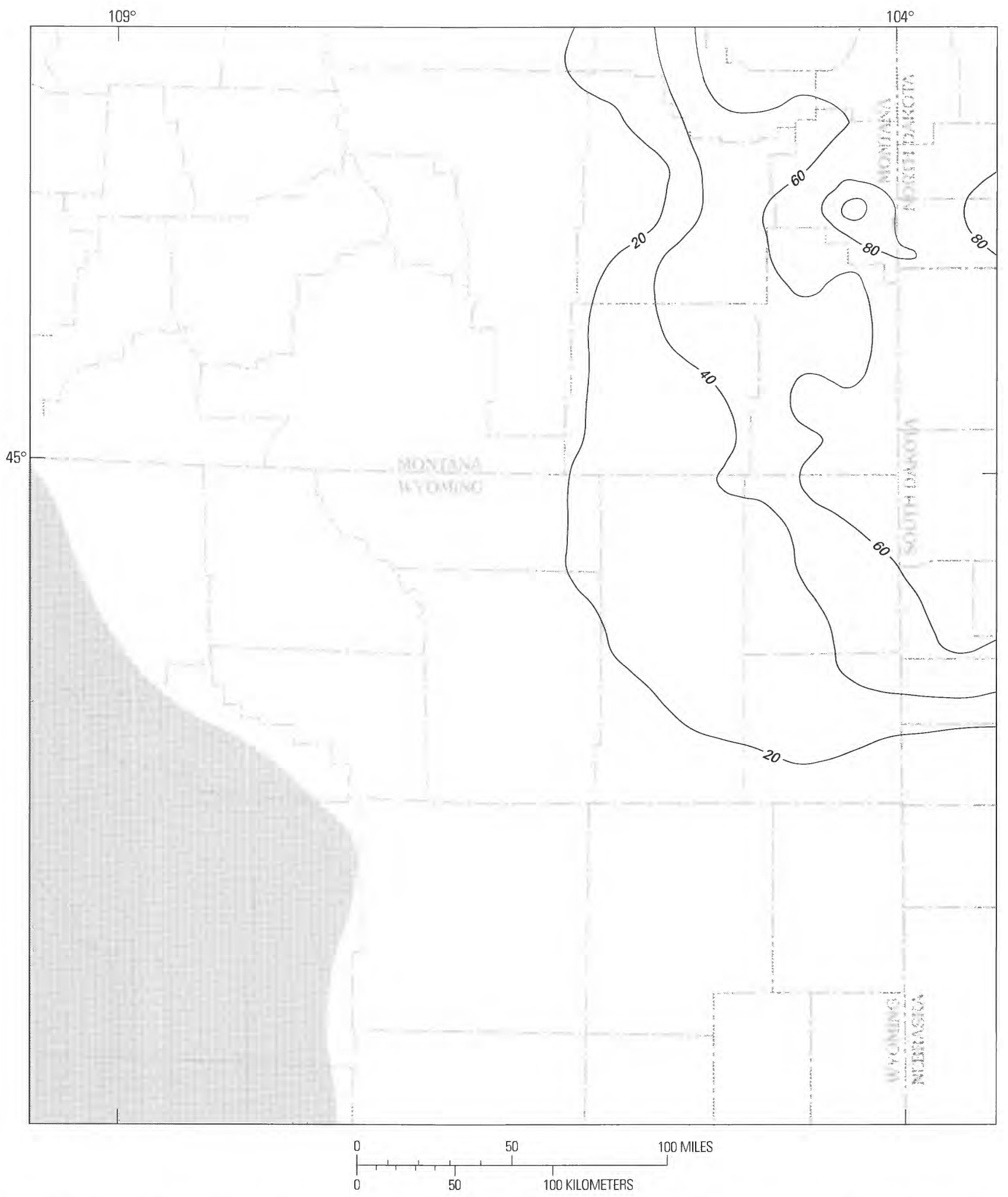

Figure 27. Isopach map of the Ice Box Member of the Winnipeg Formation of stratigraphic sequence two. Contour interval 20 $\mathrm{ft}(6.1 \mathrm{~m})$; zero-isopach line not mapped. Based on 134 wells; gridded on an approximately $15 \mathrm{mi}$ by $15 \mathrm{mi}$ grid ( $24 \mathrm{~km}$ by 24 $\mathrm{km})$. Screened area in the southwestern part of the map area is an area of very limited control. Map area shown in figure 3. 


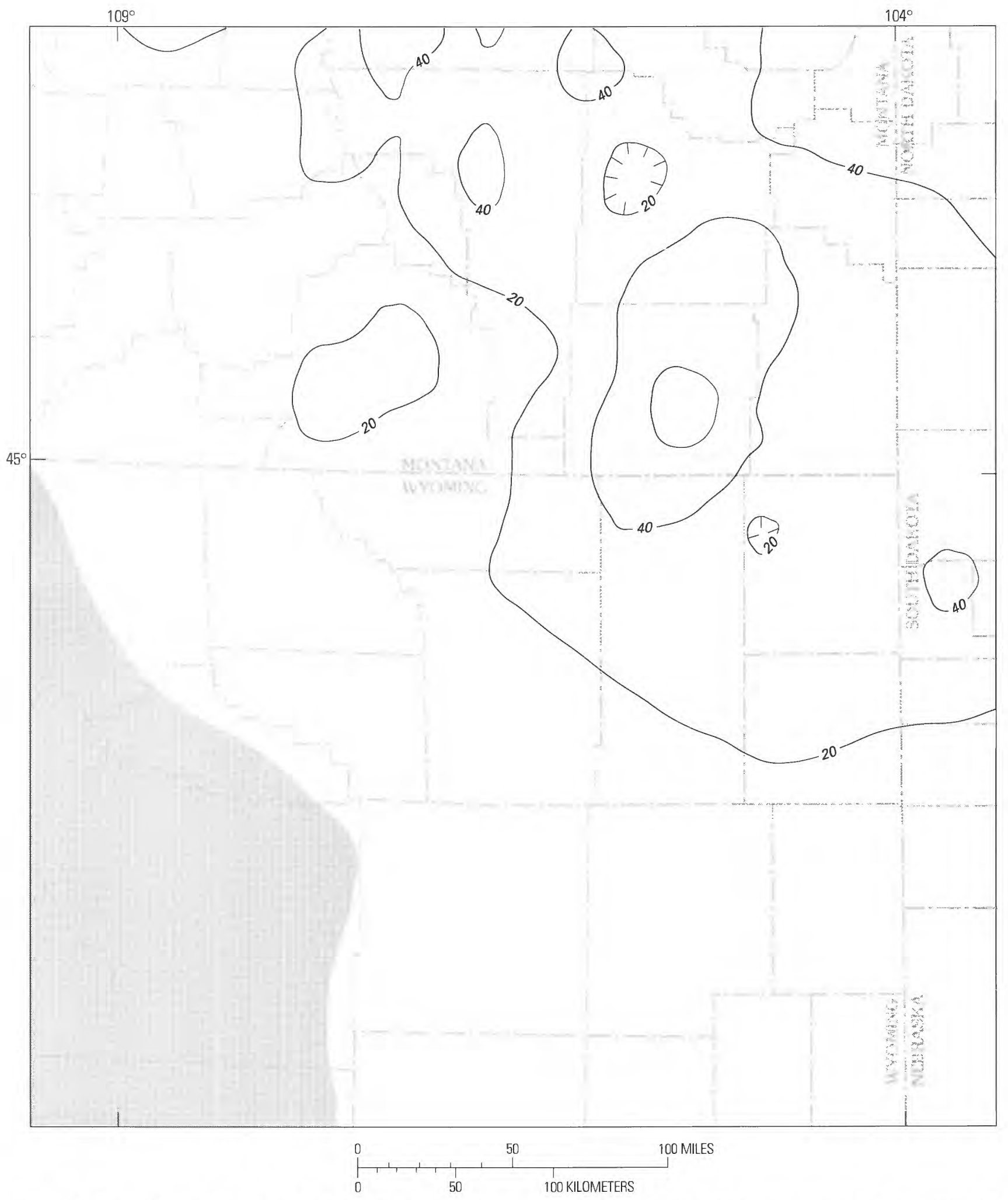

Figure 28. Isopach map of the Roughlock Member of the Winnipeg Formation of stratigraphic sequence two. Contour interval $20 \mathrm{ft}(6.1 \mathrm{~m})$; zero-isopach line not mapped. Based on 136 wells; gridded on an approximately $15 \mathrm{mi}$ by $15 \mathrm{mi}$ grid ( $24 \mathrm{~km}$ by $24 \mathrm{~km}$ ). Harding Sandstone equivalent rocks are included in the isopach map of the Roughlock, although Sweet and Bergström (1976) suggested a Black Island-Icebox equivalency. Screened area in the southwestern part of the map area is an area of very limited control. Map area shown in figure 3. 


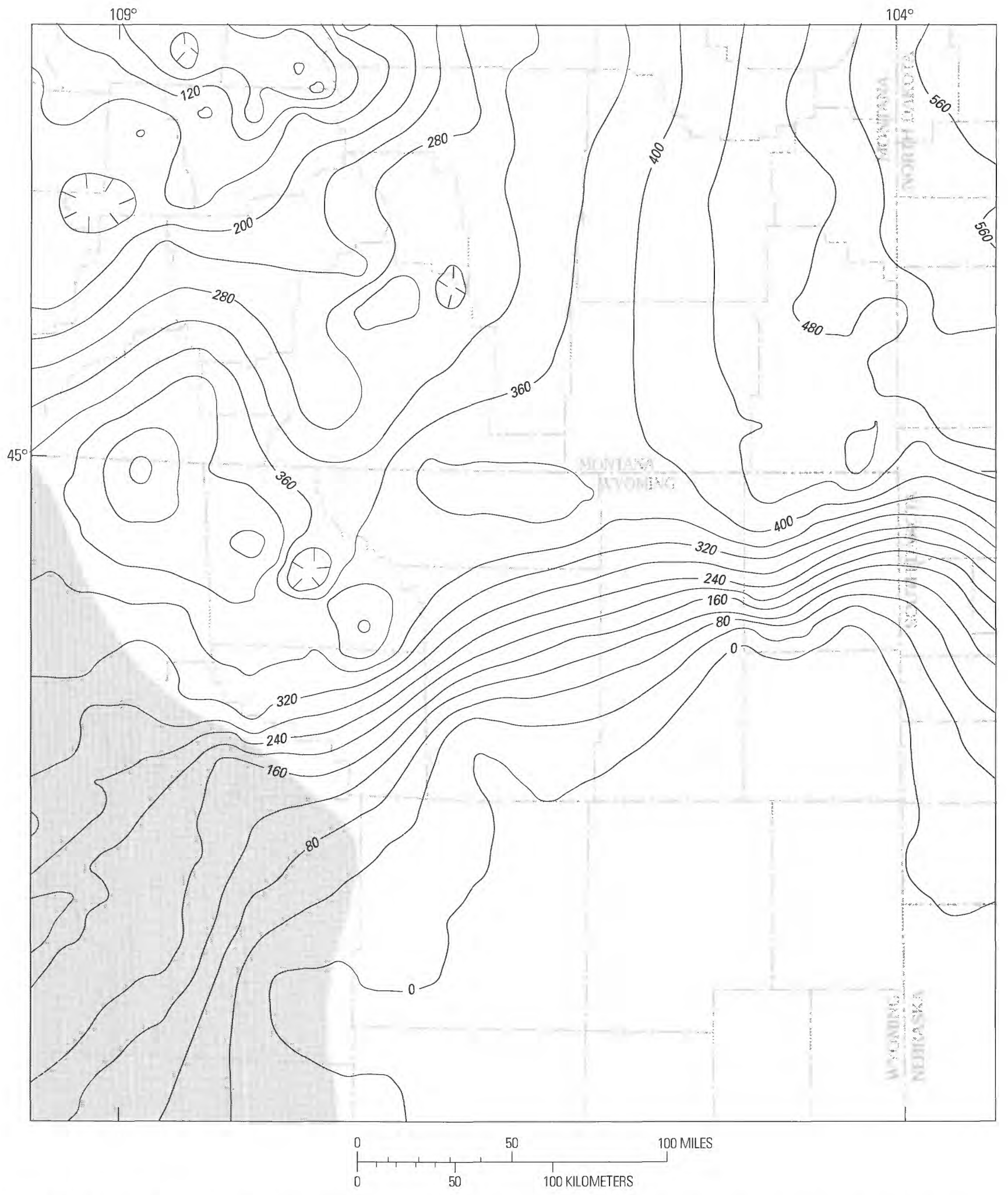

Figure 29. Isopach map of the Red River Formation-Bighorn Dolomite-Whitewood Dolomite interval of stratigraphic sequence two (mostly Upper Ordovician; in places includes Middle Ordovician Lander Sandstone Member of the Bighorn Dolomite). Contour interval $40 \mathrm{ft}(12.2 \mathrm{~m})$. Based on 186 wells; gridded on an approximately $7 \mathrm{mi}$ by $7 \mathrm{mi}$ grid ( $12 \mathrm{~km}$ by $12 \mathrm{~km})$; zero-isopach line only approximately located. Screened area in the southwestern corner of map area is an area of very limited control. Data modified from Downey (1982). Map area shown in figure 3. 
Williams (1955) discussed the Fish Haven Dolomite, a widespread equivalent of the Bighorn Dolomite in the Green River Basin. McCabe and Barchyn (1982) discussed the Red River and Stony Mountain Formations in southern Manitoba and adjacent areas in Canada.

In the Williston Basin (see, for example, pl. 2, cross sections $D^{\prime}-D^{\prime \prime}$ and $E^{\prime}-E^{\prime \prime}$ ), the lower part of the Red River makes up about two-thirds of the formation and consists of dolomitic skeletal wackestone and dense to vuggy dolomite, in part cherty or slightly argillaceous. Crinoids and brachiopods are important skeletal components in most of the wackestone and packstone (Witzke, 1980). Receptaculites and Ischadites (probably green algae) are common in three separate intervals in the Red River Formation. Nautiloids and a restricted fauna of gastropods and burrow-mottled zones are abundant in places, and cystoids, trilobites, ostracodes, bivalves, corals, stromatoporoids, sponges, bryozoans, scolecodonts, conodonts, and graptolites also are present.

The lower and upper members of the Bighorn Dolomite (fig. 19) in central Wyoming and its equivalents in the Williston Basin may be separated by an unconformity (Witzke, 1980). Sweet and Bergström (1976) showed an unconformity between the upper and lower members of the Bighorn but did not assign any time to the hiatus, based on conodont zones. Ross (1976), however, showed no unconformity in either the Williston Basin or in central Wyoming. Sweet and Bergström (1976) characterized the upper member of the Bighorn Dolomite in northern Wyoming as $100 \mathrm{ft}(30 \mathrm{~m})$ of massive thin-bedded dolomite associated locally with red shale and having a basal dolomite breccia.

The upper part of the Red River Formation in the Williston Basin is missing from the Powder River Basin and may represent the time of an erosional interval between the lower and upper members of the Bighorn Dolomite (Witzke, 1980) (fig. 19). In the Williston Basin the uppermost Red River Formation includes three cycles of evaporite deposition, each consisting, in ascending order, of bioturbated skeletal wacke-packstone, porous dolomite, nodular anhydrite, and a thin but geographically persistent argillaceous cap (Carroll, 1979; Witzke, 1980). Outside the evaporative region of the Red River, lithofacies include "pseudo-oolitic" carbonate rock (Witzke, 1980 , p. 12), cryptocrystalline dolomite, and fossiliferous dolomitic limestone, in part argillaceous (Andrichuk, 1951; Baillie, 1952; Witzke, 1980).

The Stony Mountain Formation of the Williston Basin is equivalent to the upper part of the Bighorn Dolomite in the Powder River Basin (Witzke, 1980; Peterson, 1984, p. A10) (figs. 2, 19, 22, pls. 1, 2). The Stony Mountain equivalent interval is as thick as $100-150 \mathrm{ft}(30-46 \mathrm{~m})$ in the northernmost part of the Powder River Basin (fig. 31). The lower part of the Stony Mountain conformably overlies the upper part of the Red River in the Williston Basin. Devonian erosion removed both the Red River and Stony Mountain Formations around the periphery of the Williston Basin, and the erosional edge of the Stony Mountain is nearer the center of the basin than that of the underlying Red River (figs. 29, 31). The zero-isopach line for the Stony Mountain equivalent interval trends eastnortheast from the central Bighorn Mountains to about the Wyoming-South Dakota-Montana boundary (fig. 31).

In the Williston Basin, the lower part of the Stony Mountain Formation (figs. 2, 19) comprises fossiliferous shaly limestone and thin beds and laminae of calcareous shale (Andrichuk, 1959; Fuller, 1961; Witzke, 1980). The section is more arenaceous toward the southeast in central South Dakota, where it includes sandstone. To the west and northwest it is less sandy and shaly and merges into dolomite beds. If, as suggested by Fuller (1961) and Foster (1972), Ordovician deposits were originally much more extensive in the area of the Transcontinental arch, erosion must have removed them prior to Mississippian deposition.

In the central Williston Basin, fossiliferous dolomitic limestone and fine-grained cryptocrystalline dolomite make up the upper part of the Stony Mountain (Andrichuk, 1959) except for a geographically persistent anhydrite bed at the top (the Gunton Member; Witzke, 1980). The upper part of the Stony Mountain also may be shaly to sandy. East of the Transcontinental arch, the Ordovician-Silurian boundary is an unconformity having as much as $165 \mathrm{ft}(50 \mathrm{~m})$ of relief over most of the midcontinent where the uppermost Ordovician (Neda Formation) is the "westernmost, and probably uppermost, tongue of the Queenston red shale" (Templeton and Williams, 1963, p. 133) (Witzke, 1980) and is probably of Richmondian age. In Iowa the Neda does not relate directly to the tongue of the Queenston Shale. In the Williston Basin, the youngest Ordovician rocks are the uppermost Stony Mountain and lowermost Stonewall Formations.

The uppermost Stony Mountain consists of anhydrite and shale that grade eastward in the direction of the Transcontinental arch into red sandstone having frosted grains (Porter and Fuller, 1958). The red sandstone is coarser and more abundant to the south and east, probably was derived from the Transcontinental arch (Porter and Fuller, 1958; Fuller, 1961), and marks the final phase of Stony Mountain deposition (fig. 22). The Stonewall Formation (fig. 19) overlies the Stony Mountain Formation; it is commonly included in the overlying Interlake Formation and spans the Ordovician-Silurian boundary (Stearns, 1956; Ross, 1957). The Stonewall Formation includes rhythmic alternations of pure carbonate and argillaceous or arenaceous carbonate and two widespread anhydrite units in the center of the basin (Fuller, 1961). 


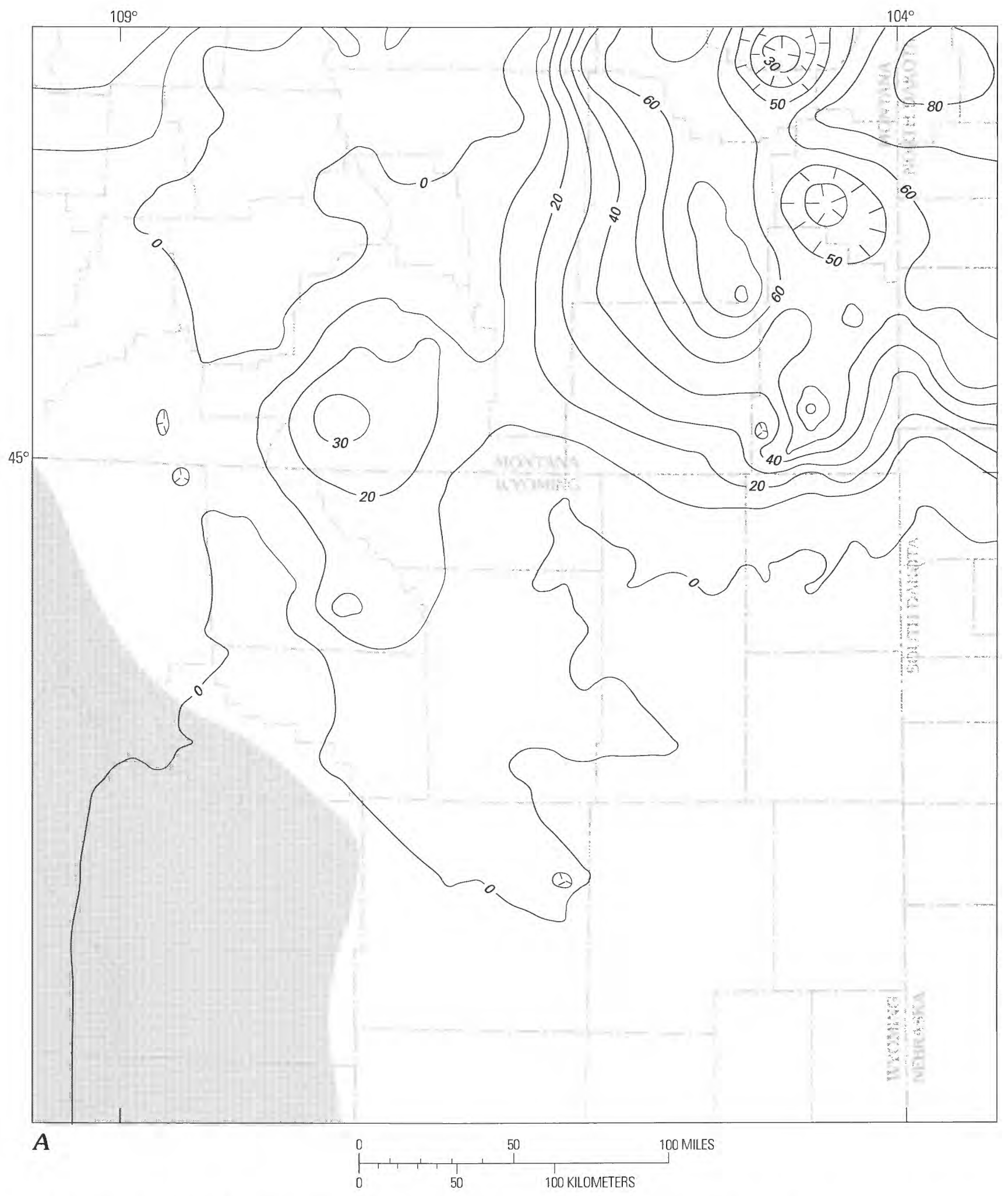

Figure 30. Lithology of the Red River Formation-Bighorn Dolomite-Whitewood Dolomite interval of stratigraphic sequence two (area shown is the same as that shown in figs. 12 and 15). Based on 133 wells; gridded on an approximately $7 \mathrm{mi}$ by $7 \mathrm{mi}$ grid ( $12 \mathrm{~km}$ by $12 \mathrm{~km}$ ); zero-percent lines not mapped. Screened area in the southwestern corner of map area is an area of limited control. Data modified from Downey (1982). Map area shown in figure 3. A, Limestone (contour interval 10 percent). 


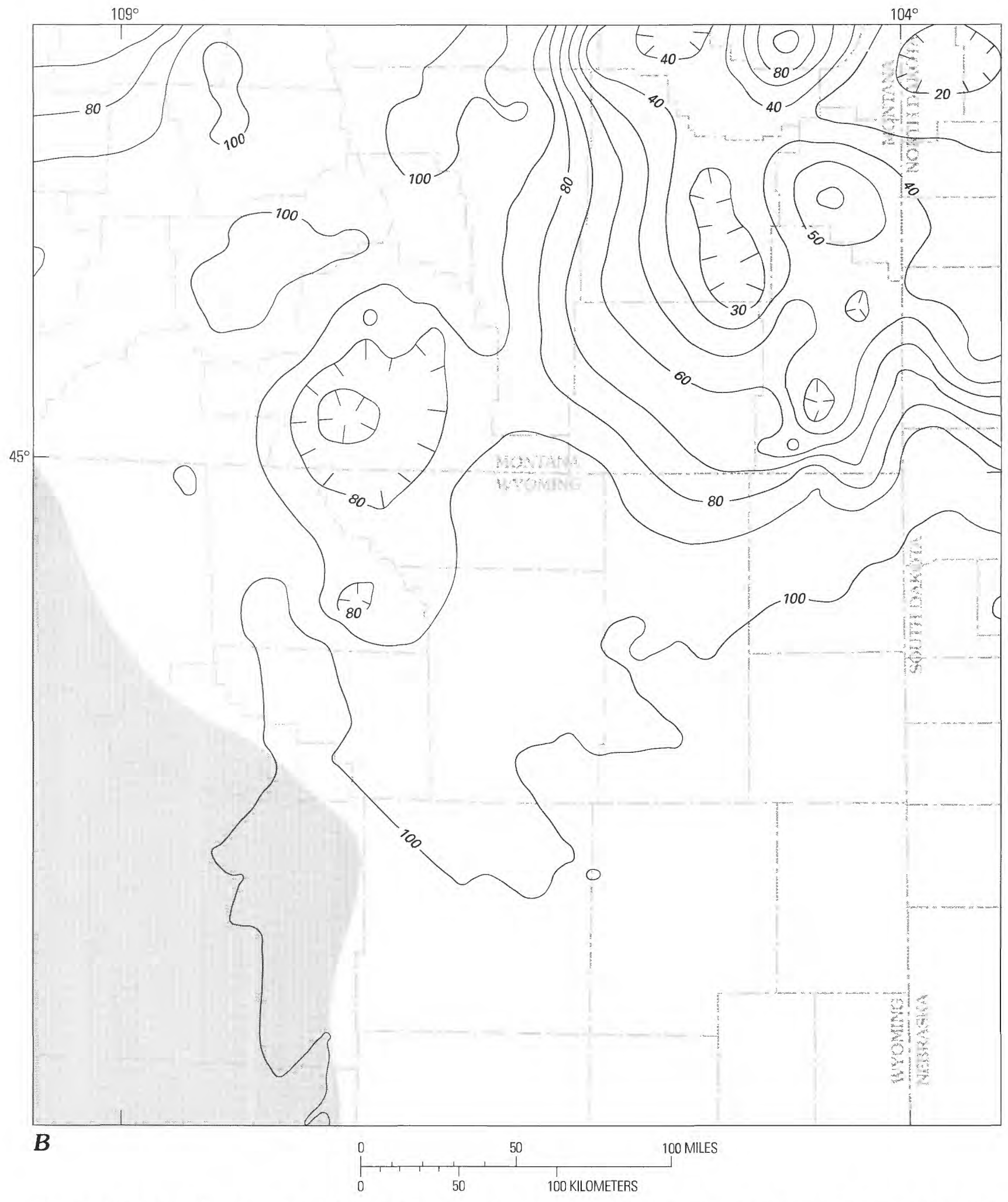

Figure 30 (continued). Lithology of the Red River Formation-Bighorn Dolomite-Whitewood Dolomite interval of stratigraphic sequence two. B, Dolomite (contour interval 10 percent). 


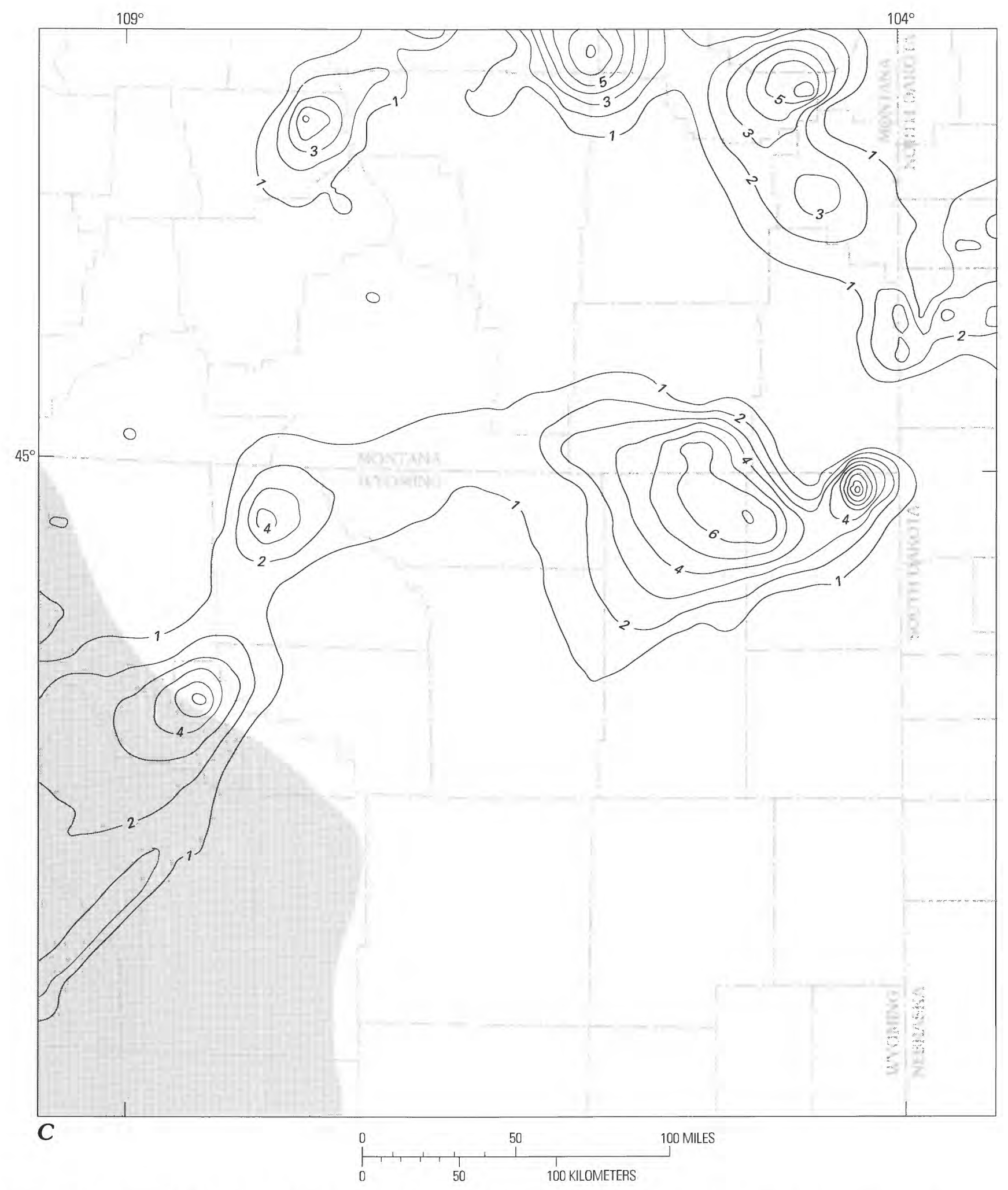

Figure 30 (continued). Lithology of the Red River Formation-Bighorn Dolomite-Whitewood Dolomite interval of stratigraphic sequence two. $C$, Shale (contour interval 1 percent). 


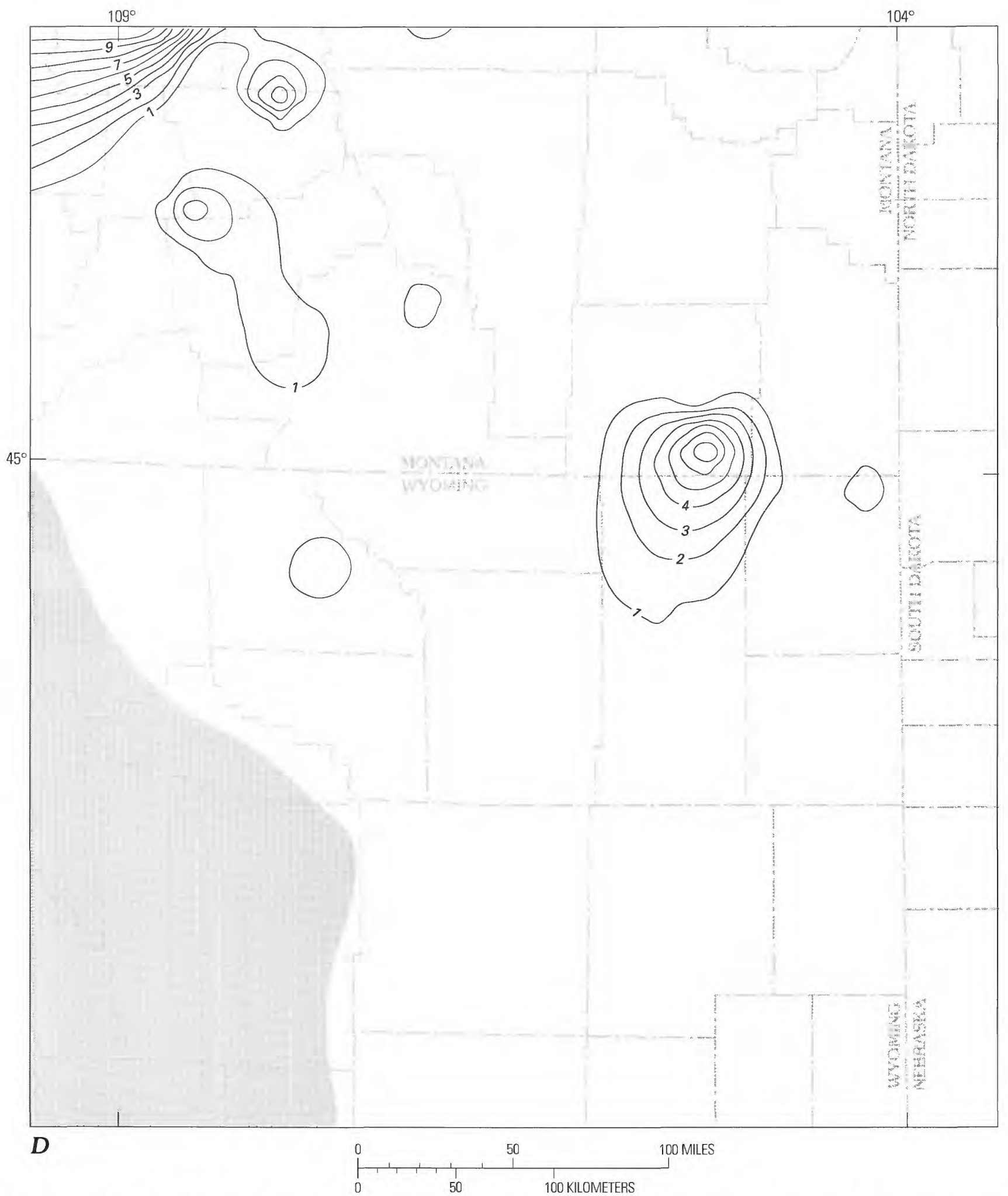

Figure 30 (continued). Lithology of the Red River Formation-Bighorn Dolomite-Whitewood Dolomite interval of stratigraphic sequence two. $D$, Sandstone (contour interval 1 percent). 


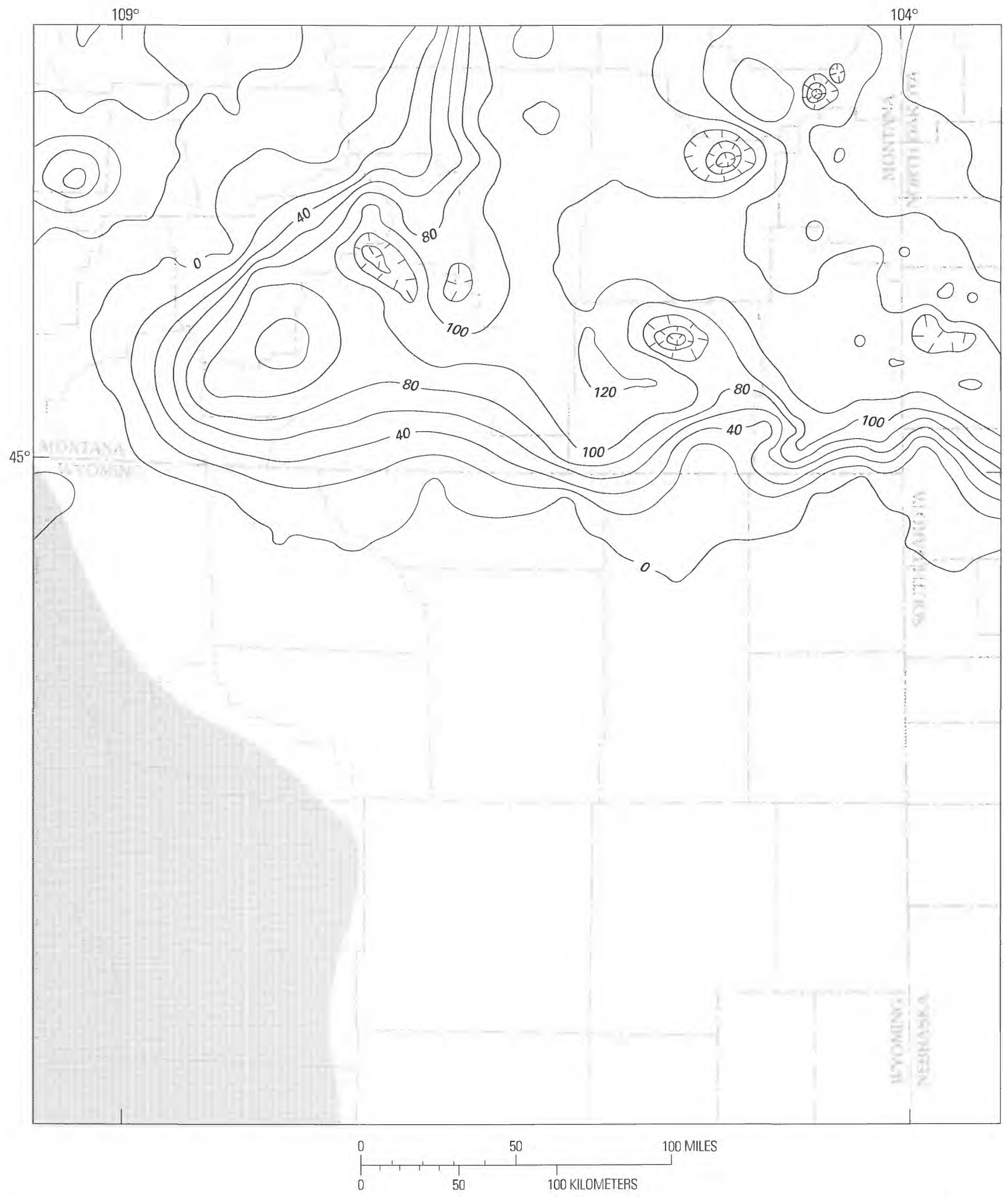

Figure 31. Isopach map of the Stony Mountain Formation and equivalent rocks of stratigraphic sequence two (Upper Ordovician). Contour interval $20 \mathrm{ft}(6.1 \mathrm{~m})$; zero-isopach line only approximately located. Based on 440 wells; gridded on an approximately $7 \mathrm{mi}$ by $7 \mathrm{mi}$ grid $(12 \mathrm{~km}$ by $12 \mathrm{~km})$. Screened area in the southwestern corner of map area is an area of limited control. Data modified from Downey (1982). Map area shown in figure 3. 


\section{Silurian Rocks}

Pre-Late Devonian erosion removed almost all of the Silurian rocks from the Powder River Basin area and adjacent Transcontinental arch, although isolated remnants of the Silurian section may be present in the northern part of the basin area (fig. 23). Fossils preserved in diatremes near the Colorado-Wyoming State line (Chronic and others, 1969) suggest that the preserved sections of Silurian rocks represent only a remnant of a once extensive sheet of Silurian rocks that was present across the Powder River Basin area. The Silurian Interlake Formation (figs. 2, 19, 23) overlies the Stonewall Formation and is more than $1,000 \mathrm{ft}(300 \mathrm{~m})$ thick in the Williston Basin (fig. 32). The formation consists mostly of dolomite; some shale and limestone is present in the eastern part of the Williston Basin (Peterson and MacCary, 1987). The Interlake was deposited in shallow-water to subaerial environments (LoBue, 1982). In Montana, Silurian rocks thin from about $700 \mathrm{ft}(213 \mathrm{~m})$ in northeastern Montana to a northwestsoutheast erosional edge that passes near Porcupine Dome (Peterson and MacCary, 1987). The Interlake Formation has lower, middle, and upper members divided by shale markers (Porter and Fuller, 1959), but due to Devonian erosion only the lowermost(?) part of the Interlake Formation extends into the northern Powder River Basin (Gibbs, 1972).

The lower and middle members of the Interlake consist mainly of light-colored, very fine grained dolomite containing fossil fragments and thin beds of anhydrite. The Interlake Formation is mostly of Early and Middle Silurian age in Saskatchewan (Brindle, 1960, p. 22) and eastern Montana (Ross, 1957), although the uppermost beds of the formation have not been dated in either of these two areas (Gibbs, 1972). Porter and Fuller (1959, p. 179; 1964 , p. 42) suggested that the uppermost bed of the Interlake Formation might be Late Silurian in age. Chronic and others (1969, p. 149) reported Early, Middle, and Late Silurian fossils from diatremes in southern Wyoming.

The basal part of the Interlake Formation (fig. 19) consists of microcrystalline dolomite that is dominantly homogeneous but contains some convoluted laminae and felted anhydrite needles. Above the base, cyclic, finingupward, bioturbated, lime packstone-mudstone with skeletal debris, and limestone conglomerate grade upward into homogeneous (burrowed?) microcrystalline dolomite. The cyclic fining-upward sequence contains anhydrite as needles in some intervals or interbedded with laminated limestone. The top of the lower member of the Interlake Formation is a sequence of interbedded dolomite, argillaceous dolomite, and anhydrite in the central Williston Basin, similar to the underlying units (Magathan, 1987).

The middle member of the Interlake Formation (fig. 19) is a thick sequence of dolomitized fine-grained, thinbedded carbonate rocks and contains a quartzose sandy unit of variegated red and green, shaly, silty carbonate interbedded with quartz sandstone and siltstone. The base of the middle member of the Interlake may be transitional from the lower member of the Interlake Formation in the central part of the Williston Basin and contains anhydrite beds. Alternating beds of skeletal-rich burrowed mud, current-bedded sandstone, reef rocks, and nonskeletal homogeneous or laminated mudstone and stromatolite overlie the basal member (Magathan, 1987).

The upper member of the Interlake Formation (fig. 19) contains widespread beds of porous oolitic, algal, and coralline dolomite and vuggy dolomitic limestone interbedded with very fine grained anhydritic to shaly dolomite (McCabe and Barchyn, 1982). The dolomitic limestone contains charophytes, ostracodes, gastropods, fish remains, pelecypods, spongiostromate algal nodules, burrows, and carbonaceous plant fragments and rhizomorphs that have been interpreted to indicate nonmarine deposition (Magathan, 1987). The upper member of the Interlake may be unconformable on the middle member.

The middle part of the upper member of the Interlake Formation (fig. 19) generally consists of a basal silicacemented quartz sandstone or thin sandstone stringers that are interlaminated with and grade upward to dark laminated limestone. The laminated limestone generally contains much terrestrial sand and silt, and many laminae contain thin-shelled ostracodes. The dark basal limestone generally grades upward to the upper part of the upper member, a pale-red limestone that may include shaly horizons near the top of the section (Magathan, 1987).

Roehl (1967) interpreted the Upper Ordovician Stony Mountain Formation and the Silurian Interlake Formation as cyclic, regressive (offlap), low-energy carbonate deposits that formed in shallow-subtidal, intertidal, supratidal, and subaerial settings analogous to modern platform deposits of the Bahama Islands. Major marine transgressions punctuated the regressive deposition cycles that ultimately filled the basin. Widespread penecontemporaneous dolomitization, solution alteration, and evaporite deposition followed basin filling in a supratidal (sabkha-wadi) environment. LoBue (1982) studied the depositional environments of the Interlake Formation of western North Dakota and recognized depositional environments similar to those of Roehl (1967). The Interlake is overlain in the Williston Basin area by rocks of Middle Devonian age. Prior to Middle Devonian deposition, microkarst developed over minor positive structural elements, and some rocks of the uppermost Interlake were removed by stream erosion.

Magathan (1987) modeled the depositional environment of the lower member of the Interlake Formation as a deep-basin in which turbidites, hemipelagic muds, and anhydrite precipitated from density-stratified brines were deposited. The depositional environment of the overlying middle member of the Interlake was interpreted as 


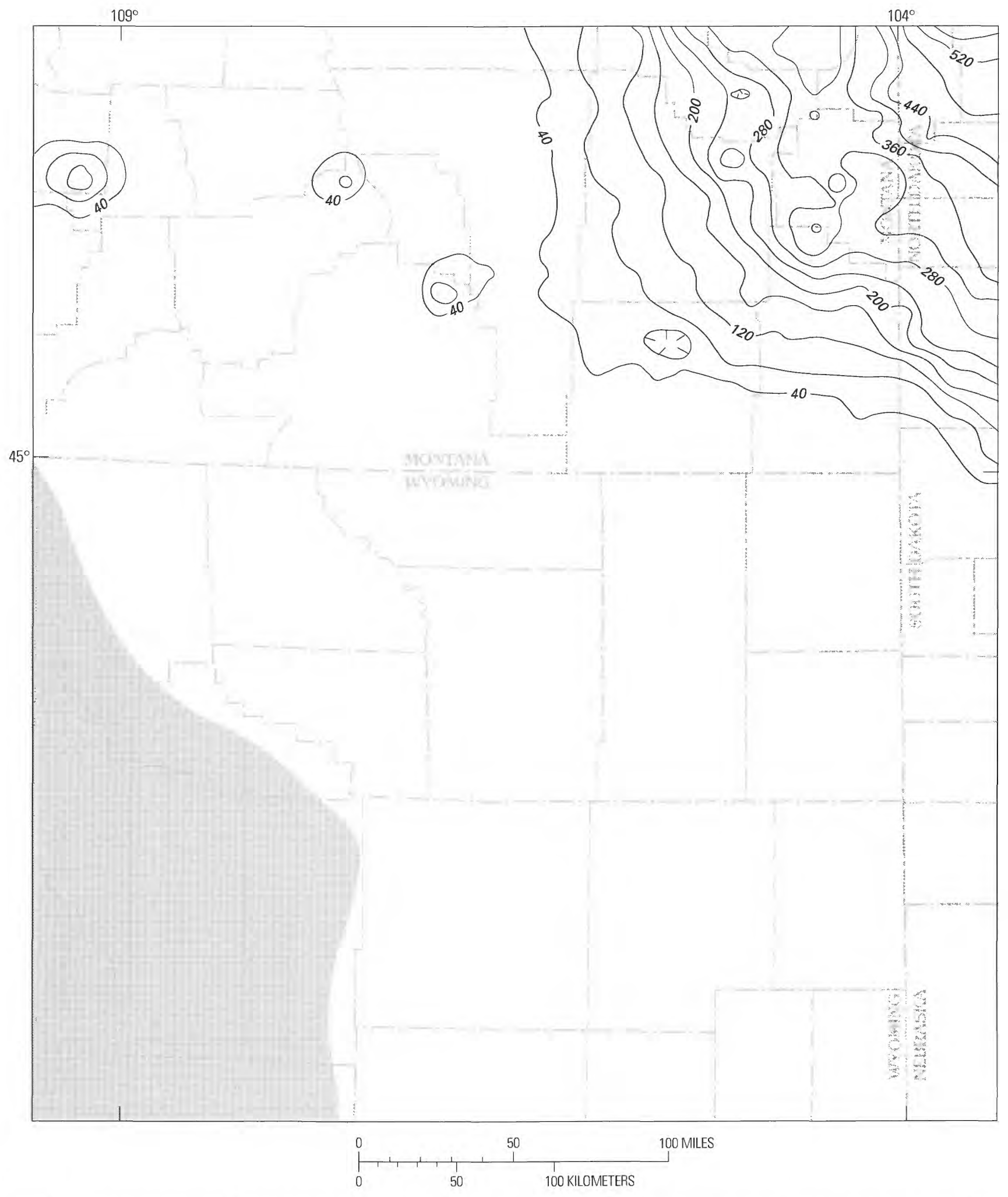

Figure 32. Isopach map of the Interlake Formation (Silurian) interval of stratigraphic sequence two. Contour interval $40 \mathrm{ft}$ (12.2 $\mathrm{m})$; zero-isopach line not mapped. Based on 440 wells; gridded on an approximately $7 \mathrm{mi}$ by $7 \mathrm{mi}$ grid (12 km by $12 \mathrm{~km}$ ). Screened area in the southwestern corner of map area is an area of limited control. Data modified from Downey (1982). Map area shown in figure 3 . 
shallower water, with reefal facies and rocks deposited by fallout or by currents, capped by more humid-climate nonmarine quartz-rich sediments subject to subaerial exposure. Rocks of the upper member of the Interlake were interpreted as nonmarine carbonates that were derived from older rocks and lacustrine or lacustrine-delta mudstone and shoreface, fluvial, or collapse-breccia carbonate rocks; these rocks were then subjected to extensive local karst formation. The shallow-water depositional model of Roehl (1967) and LoBue (1982) for the lower part of the formation, however, probably is more consistent with the overall evolution of the region.

In the Green River Basin area, the Silurian Laketown Dolomite is not known east of the type locality in Laketown Canyon, east-central Rich County, Utah. It is, however, well developed in the Bear Range in eastern Cache County, Utah. It is not present in the Wasatch Mountains or to the east in Wyoming (Williams, 1955).

\section{Middle Ordovician through Silurian Structural Trends}

Changes in the tectonic influences on sedimentation during the Middle Ordovician through Silurian are most evident in the uplift of the Central Montana structural trend (the northern extension of the Wyoming arch, fig. 5), in the Central Montana trough, and in the activation of northeast-southwest-trending structures in northern Montana (fig. 33).

The depocenter of the Williston Basin merges to the southwest with a southwest-trending trough connected to another depocenter in Carbon, Yellowstone, and Big Horn Counties, Montana, and Park, Big Horn, and Washakie Counties, Wyoming (figs. 20, 29). This trough is bordered on the north by the Central Montana uplift and on the south by the Tensleep and Thermopolis fault trends. The Central Montana structural trend, from Tooley to Madison Counties, Montana, probably represents the western margin of the craton thinned by Late Proterozoic rifting. An area of thin Middle Ordovician rocks within the trough is either associated with uplift of the trough or the result of Devonian erosion (Brown and other, 1984). The trough was south of the Central Montana trough, which was uplifted during this interval as shown by an east-trending area of thin Middle Ordovician rocks in Furgus, Petroleum, and Garfield Counties, Montana.

The lithology of the interval of the Bighorn Dolomite and its equivalents (fig. 30) reflects trends on the isopach map (fig. 29). The Bighorn Dolomite in Sheridan County, Wyoming, and Big Horn County, Montana, is thicker and also has a higher limestone content (fig. 30) than elsewhere; water in this sub-basin may have been somewhat deeper than on the surrounding shelf area, and the thickness patterns may not be merely the result of erosion. The high percentage of shale within the Bighorn equivalent (although still less than 10 percent of the interval) in the area north of the Kaycee structural trend, east of the Cedar Creek anticline, west of the unnamed structural trend from Powder River to Rosebud Counties, Montana, and south of the Rosebud arch suggests structural movement along these features during Bighorn deposition.

The Cedar Creek anticline remained active in Middle Ordovician time and marks the boundary between uniform thickening of the Red River Formation into the Williston Basin and more variable thicknesses to the west. Middle Ordovician sedimentary rocks are not present over the northwest-trending Chadron arch and the southern part of the Nesson-Pierre structural trend (Brown and others, 1984), although the zero-thickness line of Middle Ordovician rocks in the area is primarily the result of pre-Mississippian erosion. East of the Cedar Creek anticline, limestone is the major rock type in the deeper parts of the Williston Basin. The Cedar Creek anticline also shows thickness and lithofacies variations along its trend (Sandberg and Mapel, 1967; Brown and others, 1984).

The zero-thickness line of the Silurian rocks is everywhere erosional. The Interlake is dominantly dolomite, but an area of calcareous dolomite between the Nesson-Pierre and Bottineau-Bruleigh structural trends suggests that a sag or local depression may have been present south of the main Williston Basin depocenter (Brown and other, 1984).

The Winnipeg is interpreted to have been deposited within an inland sea, called the Winnipeg Basin, that was open to the southeast across the Transcontinental arch though the Nebraska sag (Porter and others, 1966). This basin extended as far north as central Manitoba and Saskatchewan and may have been connected to the contemporaneous miogeocline to the west across a highland area, a precursor to the Wyoming arch of northern Wyoming and southern Montana (fig. 5). Equivalent sediments on the Wyoming arch, reworked during later transgression, make up either the Harding Sandstone or Lander Member of the Bighorn or both. A breach in the Transcontinental arch connected the Winnipeg Basin to the Arbuckle trough to the south. The subsiding Williston Basin and continental margin to the south have similar stratigraphic sequences (figs. 19, 24). The Nebraska sag probably represents only a fragment of the connection that once existed between the Williston Basin and Ouachita trough. Cambrian and Lower Ordovician marine sedimentary rocks served as an immediate source area for sediments deposited by the transgressing sea (Witzke, 1980).

Most interpretations reconstruct the Transcontinental arch as a persistent tectonic feature extending southwestward from the Canadian Shield in generally the same position that it occupied in later Paleozoic time. The general facies trends of the Winnipeg (Porter and others, 1966; Foster, 1972) suggest, however, that the Winnipeg sea extended southward across the arch and into Colorado. 


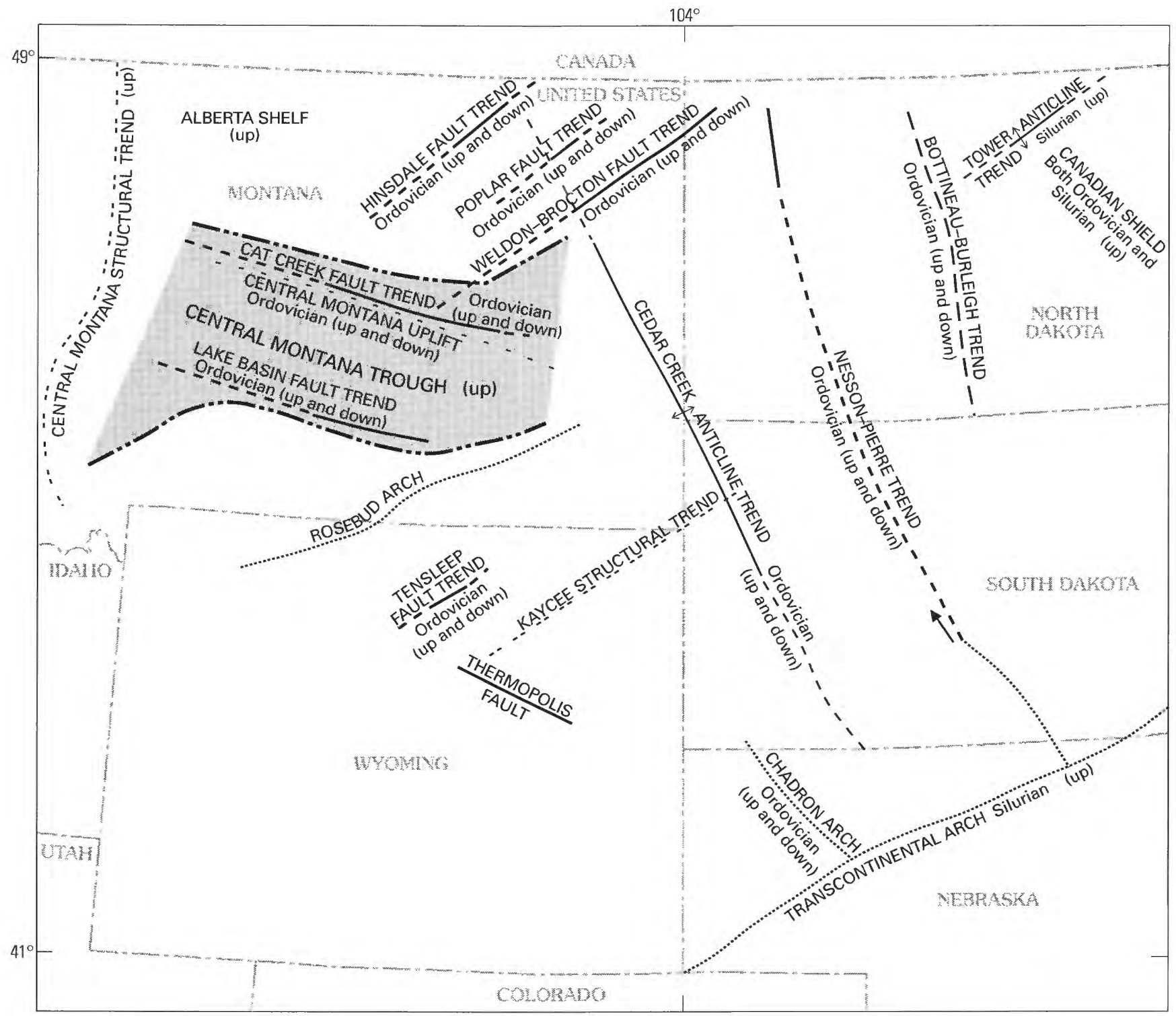

EXPLANATION

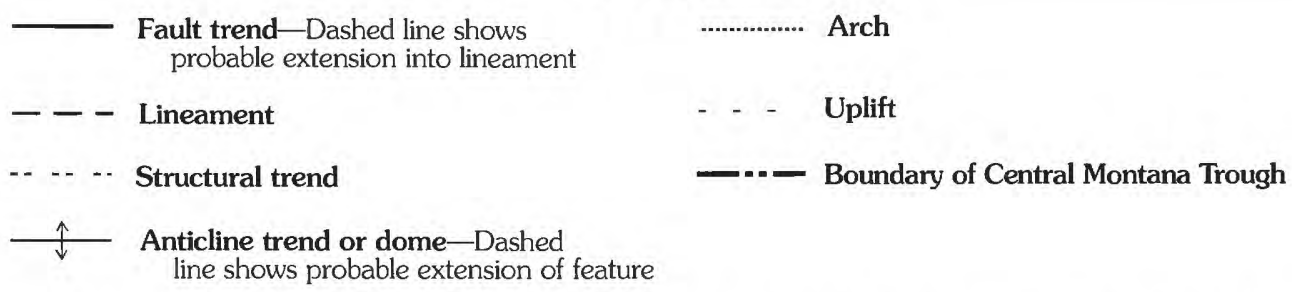

Figure 33. Paleostructural trends of stratigraphic sequence two (Middle Ordovician through Silurian) in the northern Great Plains. From Brown and others (1984).

The similarity of the stratigraphic record on the two sides of the arch suggests more than a coincidental relationship between the two sequences.

The unconformity between the Harding equivalent and the overlying Bighorn Dolomite in the Bighorn Mountains may represent either uplift of the western edge of the
Winnipeg Basin or reworking of sediment at the crest of the Wyoming arch (fig. 5) during rapid transgression following a brief regression. Foster (1972) and Witzke (1980) assigned a principally Blackriverian age to the Harding equivalent in the Bighorn Mountains and correlated it, at least roughly, with the Black Island and lower part of 
the Icebox Formations. If the depositional model of LeFever and others (1987) is correct, however, the Harding equivalent of the Bighorn Mountains is probably younger than Blackriverian in age and at least partly equivalent to the Icebox as a highly reworked nearshore sandstone deposited during the late stages of transgression when sediment supply was very low. This interpretation is consistent with the observations of Anderson (1982) that sandstone gradually replaces shale of the middle part of the Winnipeg to the west of the central Williston Basin. It also agrees with the conodont biostratigraphy of Sweet and Bergström (1976), which suggests an upper Blackriverian to lower Kirkfieldian age for the Harding equivalent.

The red staining of the unconformity at the top of the Harding equivalent in the Bighorn Mountains has been used as evidence for a great age gap between the Harding equivalent and the Lander, lacking firm paleontological evidence for the age of the Harding equivalent in central Wyoming. As discussed earlier, however, ironstones are common within the Winnipeg (Witzke, 1980), and the iron staining need not represent a long hiatus. Another permissible interpretation is that the basal sandstone of the Harding equivalent is correlative to the green quartzwacke facies of the upper part of the Black Island and Icebox and represents part of the nearshore environment (beach?) where fluvial facies (lower part of the Roughlock equivalents) are absent. The Harding equivalent may represent deposition after a long transgression and may be at least as young as, if not younger than, suggested by Sweet and Bergstrm (1976). The Lander Sandstone Member, the basal unit of the Bighorn Dolomite in the Bighorn Mountains, represents sand of the Harding equivalent that was reworked during transgression in Middle Ordovician time.

A major regression in mid-Maysvillian time produced unconformity at the base of the Leigh Member (the unconformity between the lower member and the Priest Canyon Member of the Fremont Limestone in Colorado). In the Williston Basin, cyclic evaporite in the upper part of the Red River Formation marks this regression. In contrast to the Winnipeg, these rocks probably represent arid-climate deposition, the Williston Basin lying in the arid tradewinds belt by Late Ordovician time (Maysvillian-Richmondian) (Witzke, 1980). Available dating (fig. 19) suggests that the erosion or nondeposition beneath the upper part of the Bighorn is greatest in western Wyoming (Beartooth Butte section) and decreases eastward toward central Wyoming.

Pre-Mississippian erosion in the Black Hills area, South Dakota, precludes estimation of the total thickness of the Whitewood Dolomite deposited there, but deposition probably was continuous through the Maysvillian in Montana, North Dakota, Saskatchewan, and Manitoba and almost continuous in Kansas and Nebraska (within the Nebraska sag). Hiatuses in deposition also occurred in Oklahoma. The mid-Maysvillian regression is most evident around the margins of the interior basin, which supports the model of a basin open to the south so that deposition lapped up onto a highland area west of the Powder River Basin (the Wyoming arch, fig. 5). Tectonic activity along the Ouachita margin in Oklahoma probably uplifted the basin margins.

\section{STRATIGRAPHIC SEQUENCES THREE, FOUR, AND FIVE-DEVONIAN THROUGH MISSISSIPPIAN ROCKS}

Sedimentary sequences three, four, and five include rocks of Devonian through Mississippian age in the Powder River Basin area (figs. 34, 35). Sequence three is made up primarily of Middle and Upper Devonian rocks, although isolated remnants of Lower Devonian rocks are present. Sequence four is primarily older Mississippian rocks and includes rocks of Kinderhookian, Osagean, and older Meramecian ages. Sequence five is made up of younger Meramecian and Chesterian rocks. Sequences three, four, and five have closely related tectonic histories, which will be discussed together.

The Devonian through Mississippian sequences reflect a period of active tectonism along the western margin of the North American craton, although Jurassic through Tertiary deformation of the Cordilleran orogeny has obscured the tectonic relationships necessary to unravel the complete tectonic setting of the region. Stratigraphic sequence four (older Mississippian) is an important stratigraphic section in the region, both as an aquifer (Brown and others, 1984; Peterson, 1984; Downey and others, 1987) and, primarily in the Williston Basin, as a petroleum reservoir rock (see, for example, Kent, 1987) and a source of petroleum (see, for example, Webster, 1987).

At the end of Mississippian time, continent-continent collision along the eastern and southern margins of North America caused the Allegheny, Ouachita, Arbuckle orogenies, and all combined to elevate the northern Great Plains and produce the ancestral Rocky Mountains (Kluth and Coney, 1981; Kluth, 1986). Highlands developed because of intracontinental wrench-fault deformation related to the Ouachita orogeny (Flawn, 1961; Veil, 1979; Dickinson, 1981). This combination of events ushered in an episode of sedimentation distinguished by interfingering of terrigenous clastic rocks with marginal-marine evaporite and eolianite that characterizes Pennsylvanian through Middle Triassic deposition. The emergence of local highlands during the ancestral Rocky Mountain orogeny influenced cyclic sedimentation (Kluth and Coney, 1981; Kluth, 1986). Conglomerate and arkose adjacent to the highland margin grade northward to marginal-marine rocks in the area of the present Powder River Basin (Ziebarth, 1964; Houston, 1969; Grenda, 1978). 


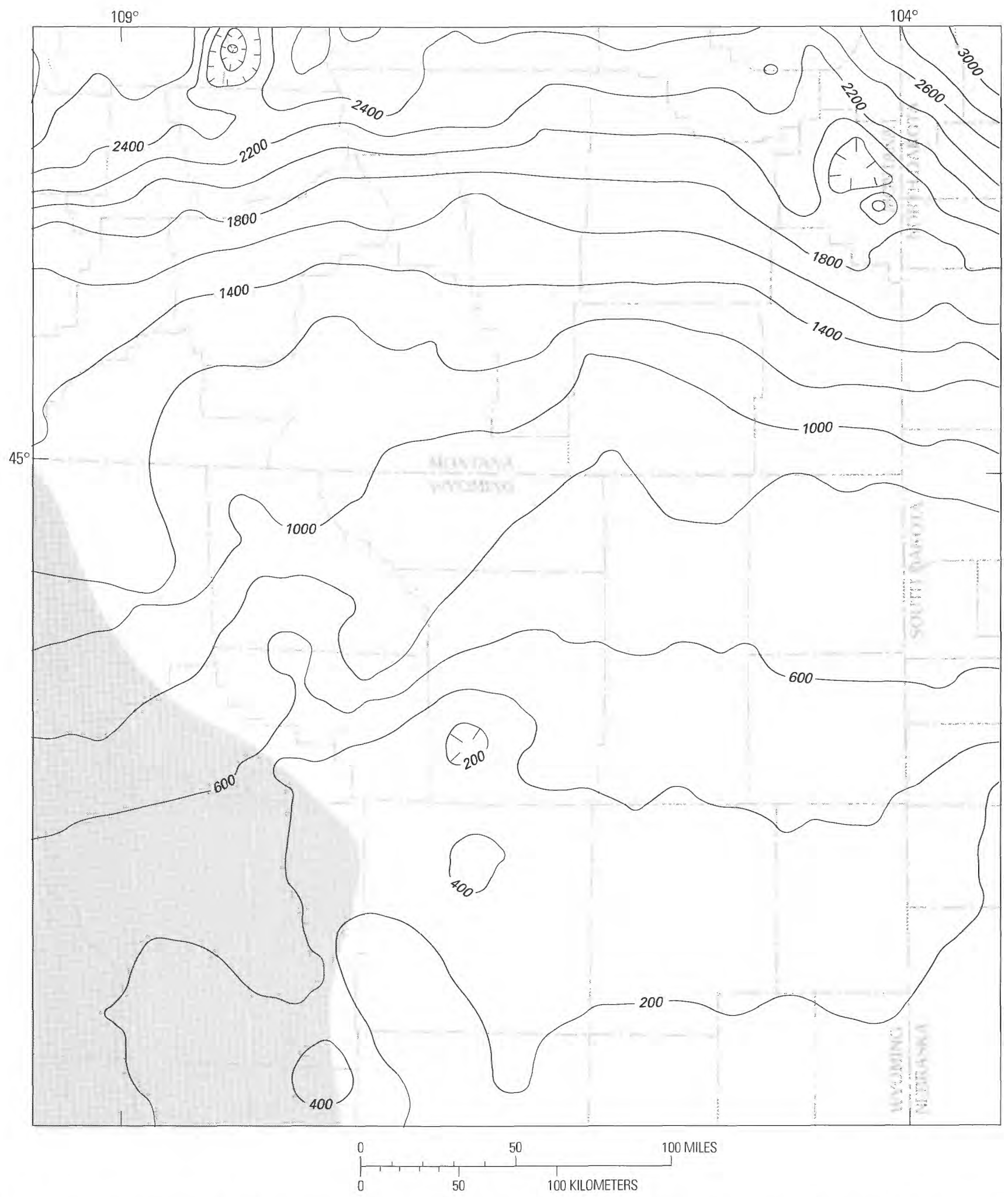

Figure 34. Isopach map of stratigraphic sequences three, four, and five, combined. Contour interval $200 \mathrm{ft}$ (61 m); zero-isopach line not mapped. Based on 439 wells; gridded on an approximately $7 \mathrm{mi}$ by $7 \mathrm{mi}$ grid ( $12 \mathrm{~km}$ by $12 \mathrm{~km})$. Data modified from Downey (1982). Map area shown in figure 3. 


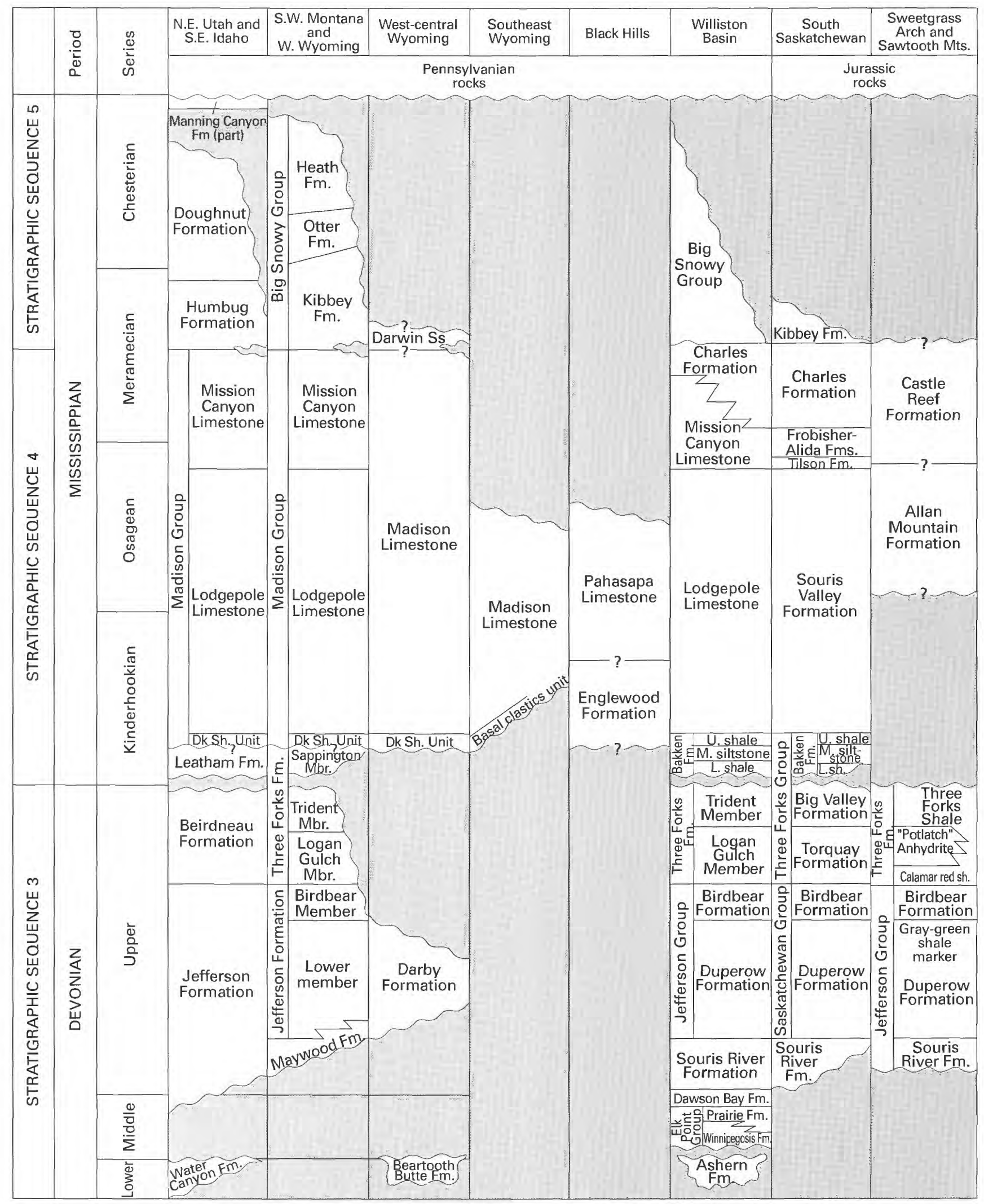

Figure 35. Stratigraphy of stratigraphic sequences three, four, and five (Devonian and Mississippian). Devonian units modified from Benson (1966, fig. 2); Mississippian units modified from Maughan and Roberts (1967), Ballard and others (1983), Peterson (1984), Adler and others (1987), Kent and others (1988), and others. 
Devonian through Mississippian Regional Tectonics

The unconformity beneath Upper Devonian rocks (fig. 2) developed during a major reordering of the tectonic regime of the cratonic margins. The western margin of North America was significantly uplifted and eroded during Middle Devonian time, and erosion removed most of the older Devonian and Silurian strata (fig. 23), as well as many of the older rocks, from the Wyoming shelf. Along the east coast, the Acadian orogeny of Middle and Late Devonian age records the closing of a narrow ocean basin and the docking of terranes against the northern and southern Appalachian continental margins (Williams and Hatcher, 1982). By the close of the Devonian Period (fig. 36 ), discontinuous uplifts along the western margin of the continent supplied detrital debris to the continental interior for the first time since the Precambrian (Peterson, 1980b). A disconformity between rocks of Cambrian age and the Mississippian Madison Limestone in southeastern Wyoming probably is due to erosion rather than to nondeposition (Keefer and Van Lieu, 1966).

Mesozoic thrusting along the western margin of the craton has overprinted the Paleozoic structural and depositional history of the margin, and the tectonic history of the area is difficult to decipher (Dover, 1980); at least 10 models have been developed to explain Devonian and Mississippian tectonic activity along the western margin of the craton (Trexler and Nitchman, 1990). The primary tectonic controls on Devonian and Mississippian sedimentation along the western margin of the craton generally have been interpreted as a Late Devonian collision in central Nevada known as the Antler orogeny (Birchfield and Davis, 1972; Churkin, 1974). The Antler orogeny has been interpreted as an island arc-continent collision that superimposed deep-water assemblages on the west (the Roberts Mountain allochthon) over the Paleozoic continental shelf (Dickinson, 1977, 1981; Cohen, 1982; Speed and Sleep, 1982) and shed clastics eastward onto the craton as the thrust sheets were uplifted (Poole, 1974; Windley, 1977; Cohen, 1982) (fig. 37).

Middle Devonian (pre-Antler) uplift of the Wyoming shelf and adjacent areas also may be related to subduction along the western margin of the craton and the development of an accretionary prism (N.J. Silberling, U.S. Geological Survey, written commun., 1989), tectonic activity that has been called the Klamath orogeny (Boucot and others, 1974). This event is interpreted to have affected areas from the Klamath Mountains in northern California to eastern Washington and north-central British Columbia and to correspond to Middle to Late Devonian granitoid intrusion in east-central California (Merguerian and Schweickert, 1987). The position of the Klamath terrane relative to North America during the Middle and Late Devonian, however, is uncertain.
The Antler orogeny began at least as early as the Devonian-Mississippian (Famennian-Tournaisian) boundary and continued into the Middle Pennsylvanian (Roberts, 1951; Roberts and others, 1958; Johnson, 1971; Boucot and others, 1974). Trexler and Nitchman (1990) recently interpreted two phases of Antler deformation: (1) Kinderhookian (fig. 38) collision of the western edge of North America with the Antler allochthon and downwarping of the continental margin to form a foreland basin, followed by submarine fan deposition until the end of Osagean time (fig. 39), and (2) uplift and low-amplitude folding of the foreland basin in middle or late Meramecian time (fig. 40), followed by uplift to the east of the foreland basin no later than the end of Chesterian time (fig. 41). Kinderhookian (figs. 2, 37, 38) transgression onto the shelf reestablished normal marine carbonate deposition (Kent, 1972) as a carbonate platform onlapped the Wyoming shelf from the east (Rose, 1976) and probably from the north and west as well. Onlap of the craton was principally controlled by tectonic activity along the Cordilleran margin.

About the same time as the Antler orogeny, early Paleozoic deposition in the Canadian Arctic Islands area was terminated by the Ellsmerian orogeny, which caused as much as $16,400 \mathrm{ft}(5,000 \mathrm{~m})$ of sediment to be shed southward from Ellsmere Island. The coincidence of these events in time has been used to suggest that the Antler and Ellsmere orogenies were linked by a sinistral fault system propagating southward from the Arctic Islands along the cratonic margin in response to east-west compression (Eisbacher, 1983). Other possibilities exist for pre-Late Devonian (pre-Antler) tectonic disturbance of the western margin of the continent, such as wrench faulting associated with subduction along the Ouachita margin; however, the driving mechanism for pre-Late Devonian uplift on the Wyoming shelf cannot be stated with certainty.

In the Devonian Period, restricted circulation and evaporitic deposition dominated the shelf areas. The initial Devonian transgression onto the western margin of the craton is represented by the Lower and Middle Devonian sequence in Canada (Grayston and others, 1966) that is made up of evaporite, carbonate, and terrigenous clastic rocks deposited in a basin between the craton to the east and the Peach River arch and its southern extension, the Alberta arch, to the west. Buildups of carbonate along the continental margins and around shallow basins reduced the terrigenous sediment supply to the basin interiors, producing starved basins (Wilson, 1975). As transgression continued, Middle Devonian deposition extended to the south and east and onlapped the eastern edge of the Alberta arch. The base of the Devonian sequence is younger to the south and is probably of latest Early Devonian age in the Williston Basin (Baillie, 1953; Grayston and others, 1966; Rosenthal, 1987), where it records an influx of terrigenous clastic and supratidal carbonate rocks and represents initial 


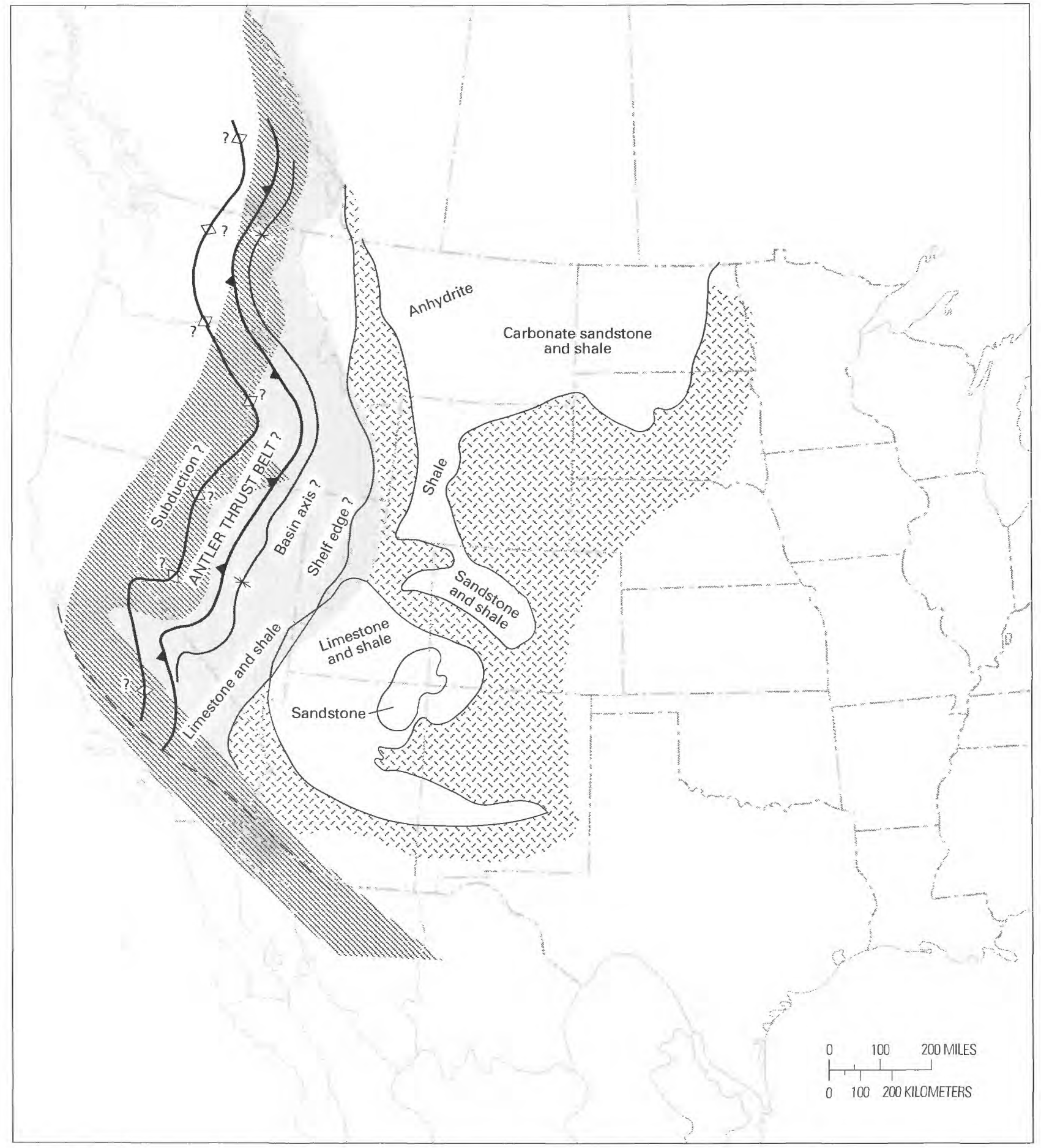

Figure 36. Paleogeography at beginning of stratigraphic sequence three (lower Upper Devonian). Random hatch pattern indicates area of nondeposition (some of these areas may be the result of later erosion and their paleogeographic relationships are uncertain); shading indicates area of uncertain paleogeography because of later compression and extension; diagonal rules show area of allochthonous continent accreted in post-Paleozoic time. Modified from Baars (1972), Poole (1974), and others.

deposits of the overlying Middle Devonian-Mississippian transgressive sequence (Peterson and others, 1987). In Middle Devonian time, buildups of stromatoporoid dotted the basins of western Canada, especially along their edges.
During regression, toward the end of the Givetian (late Middle Devonian), these basins filled with evaporites.

Renewed transgression in early Frasnian time led to widespread deposition of fossiliferous gray shale and 


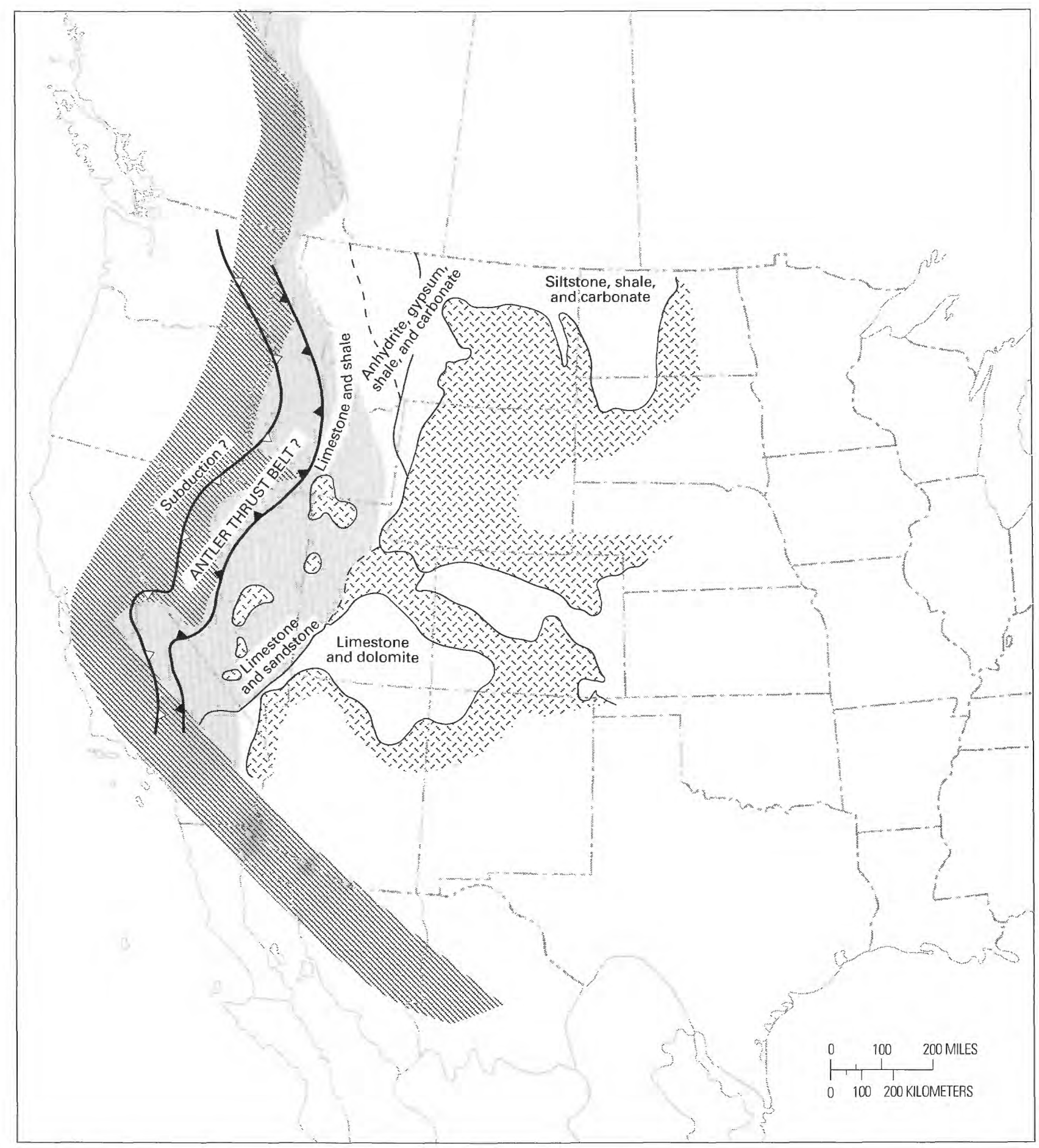

Figure 37. Paleogeography at beginning of stratigraphic sequence four (Upper Devonian or Lower Mississippian). Random hatch pattern indicates area of nondeposition (some of these areas may be the result of later erosion and their paleogeographic relationships are uncertain); shading indicates area of uncertain paleogeography because of later compression and extension; diagonal rules show area of allochthonous continent accreted in post-Paleozoic time. Modified from Baars (1972), Poole (1974), and others.

limestone and carbonate complexes in the Alberta Basin. A vast back-reef lagoon, more than $600 \mathrm{mi}(965 \mathrm{~km})$ across, developed along the southern margin of the Alberta Basin and extended southward to a sandy shore in
South Dakota and Wyoming (the Frasnian Duperow Formation in the Williston Basin) (Wilson, 1975). The lagoonal deposits are chiefly dolomite through a wide belt that extends from southeastern Montana to the northwest 


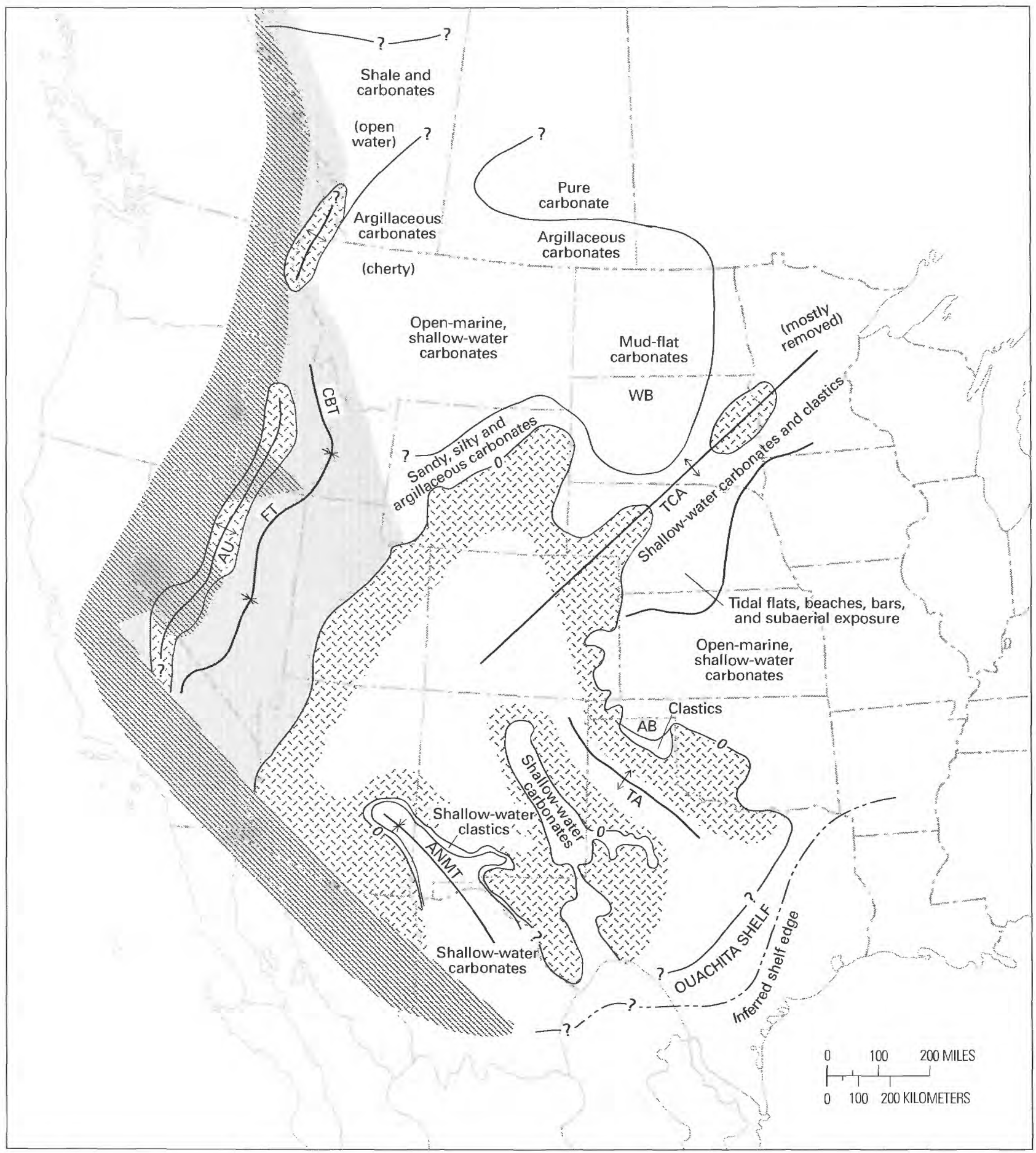

Figure 38. Paleogeography of Kinderhookian (Lower Mississippian) part of stratigraphic sequence four. Random hatch pattern indicates area of nondeposition (some of these areas may be the result of later erosion and their paleogeographic relationships are uncertain); shading indicates area of uncertain paleogeography because of later compression and extension; diagonal rules show area of allochthonous continent accreted in post-Paleozoic time. AB, Anadarko Basin; A-NMT, Arizona-New Mexico trough; AU, Antler uplift; CBT, Copper Basin trough; FT, foreland trough; TA, Texas arch; TCA, Transcontinental arch; WB, Williston Basin. Modified from Craig and others (1979).

across the central part of Saskatchewan (Peterson, 1984). Sabkha anhydrite and radioactive silty gray-green dolomitic mudstone mark the boundaries of the cycles, about a dozen of which can be traced from southern Alberta across the Williston Basin of Saskatchewan and southern North Dakota and are identifiable in outcrops of the 


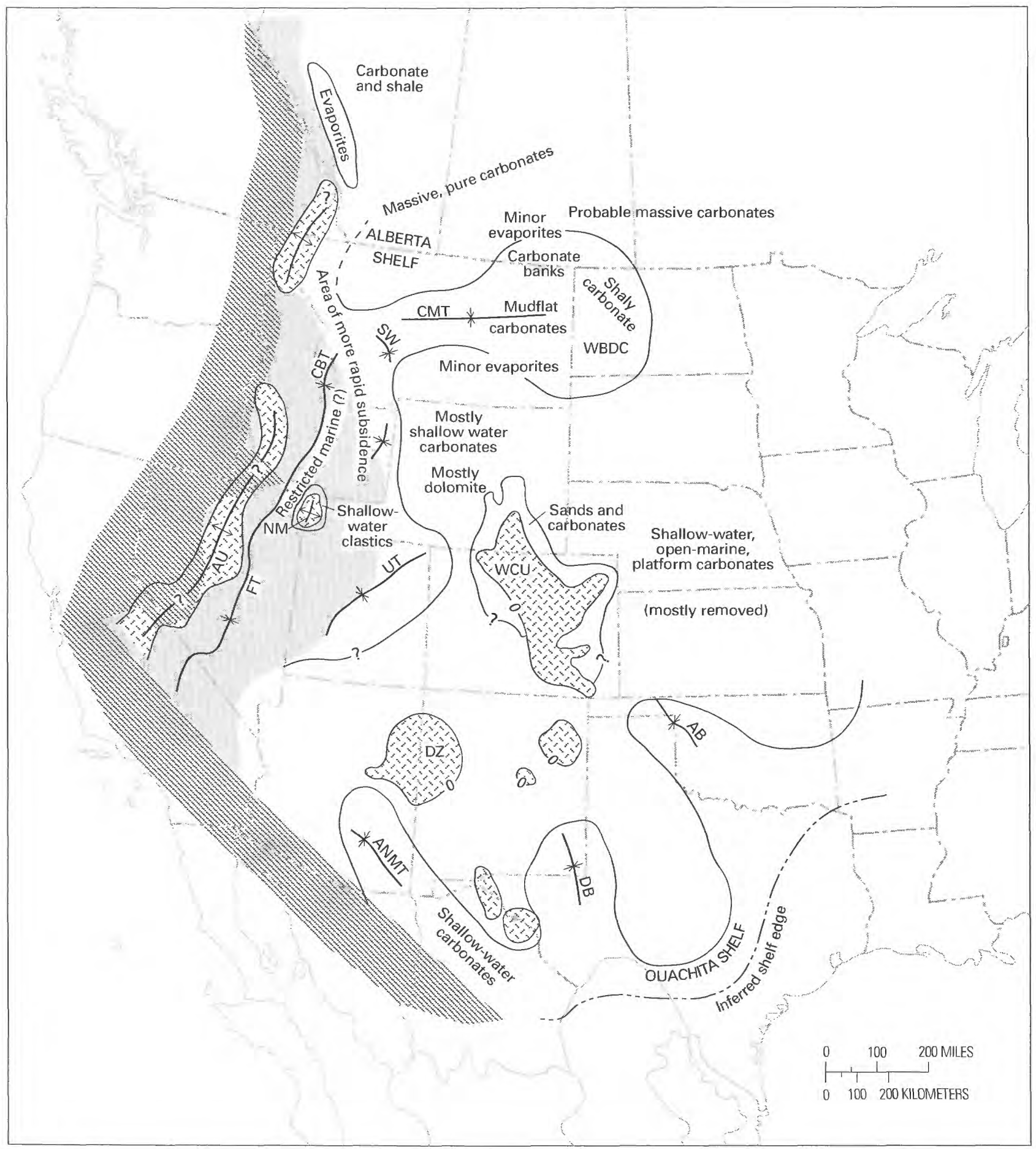

Figure 39. Paleogeography of Osagean (Early Mississippian) part of stratigraphic sequence four. Random hatch pattern indicates area of nondeposition (some of these areas may be the result of later erosion and their paleogeographic relationships are uncertain); shading indicates area of uncertain paleogeography because of later compression and extension; diagonal rules show area of allochthonous continent accreted in post-Paleozoic time. AB, Anadarko Basin; ANMT, Arizona-New Mexico trough; AU, Antler uplift; CBT, Copper Basin trough; CMT, Central Montana trough; DB, Delaware Basin; DZ, Defiance-Zuni uplift; FT, foreland trough; SW, Sweetwater trough; UT, Uinta trough; WCU, Wyoming-Colorado uplift; WU, Wendover uplift. Modified from Craig and others (1979). 


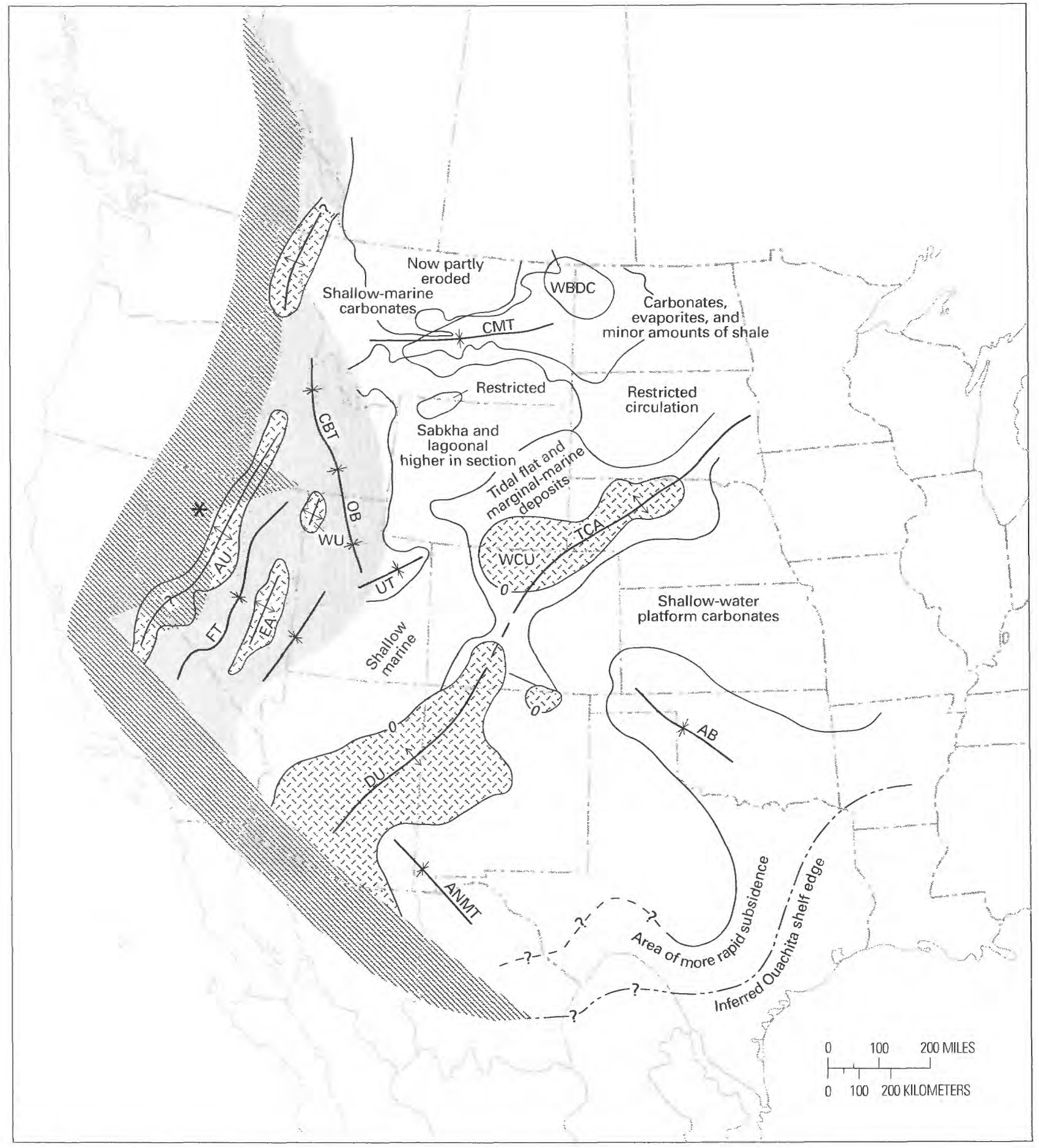

Figure 40. Paleogeography of the Meramecian (Late Mississippian) part of stratigraphic sequence four. Random hatch pattern indicates area of nondeposition (some of these areas may be the result of later erosion and their paleogeographic relationships are uncertain); shading indicates area of uncertain paleogeography because of later compression and extension; diagonal rules show area of allochthonous continent accreted in post-Paleozoic time. AB, Anadarko Basin; ANMT, Arizona-New Mexico trough; AU, Antler uplift; CMT, Central Montana trough; DU, Defiance uplift; EA, Ely arch; FT, foreland trough; OB-CBT, Oquirrh Basin-Copper Basin trough; TCA, Transcontinental arch; UT, Uinta trough; WBDC, Williston Basin depocenter; WCU, Wyoming-Colorado uplift; WU, Wendover uplift. Modified from Craig and others (1979). 


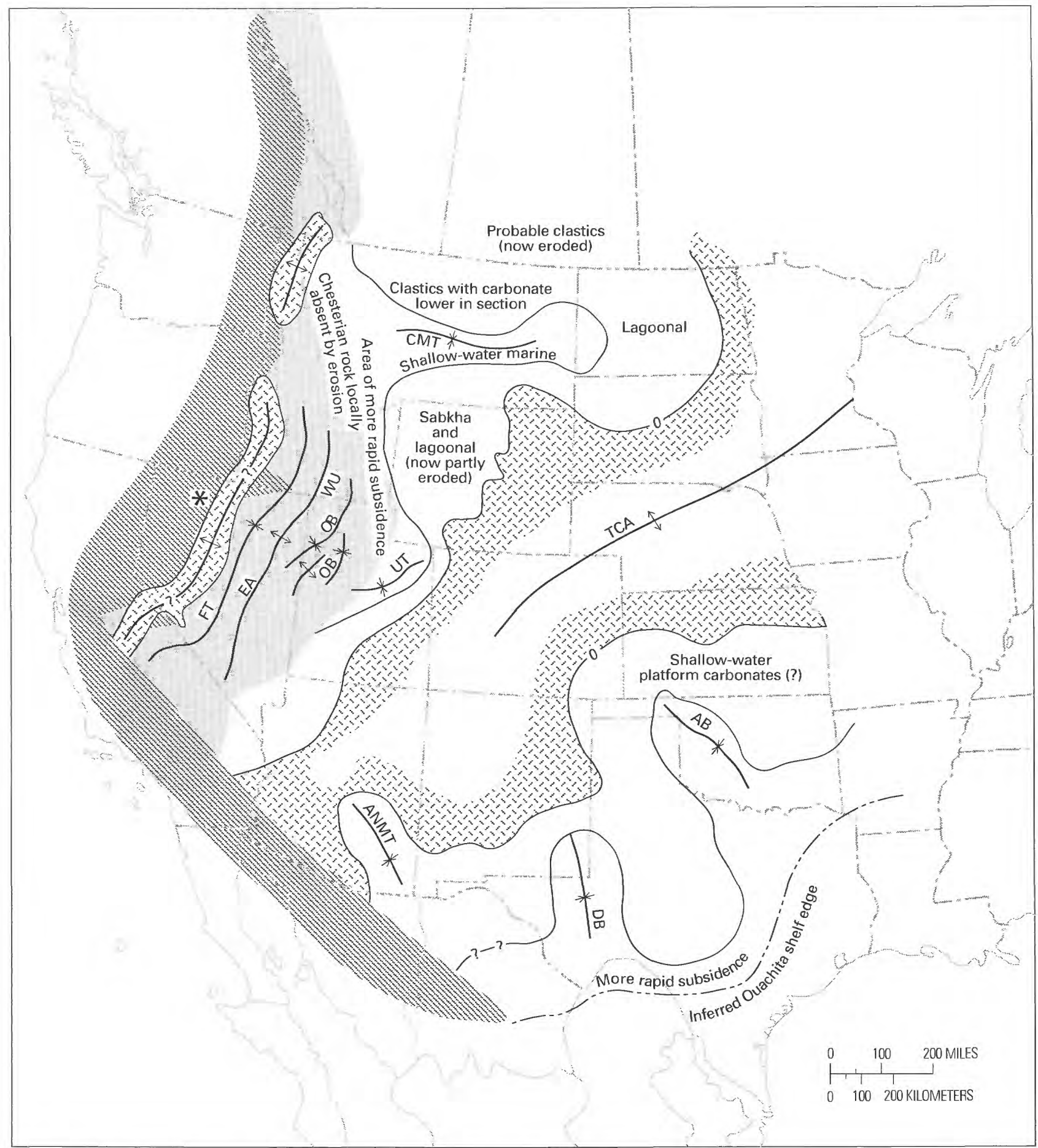

Figure 41. Paleogeography of stratigraphic sequence five (Chesterian, Late Mississippian). Random hatch pattern indicates area of nondeposition (some of these areas may be the result of later erosion and their paleogeographic relationships are uncertain); shading indicates area of uncertain paleogeography because of later compression and extension; diagonal rules show area of allochthonous continent accreted in post-Paleozoic time. AB, Anadarko Basin; ANMT, Arizona-New Mexico trough; AU, Antler uplift; CMT, Central Montana trough; DB, Delaware Basin; EA, Ely arch; FT, foreland trough; OB, Oquirrh Basin; TCA, Transcontinental arch; UT, Uinta trough; WU, Wendover uplift. Modified from Craig and others (1979).

Jefferson Formation in Montana (Wilson, 1967, 1975). The cycles are considered nonorogenic and the result of worldwide eustatic mechanisms (Wilson, 1975).
Upper Devonian rocks (fig. 2, 35) overlap Middle Devonian rocks and extend across most of central Montana to western Wyoming and to the northwest into the 
Cordilleran miogeocline (Peterson, 1984). Bjorlie (1979) interpreted Upper Devonian to Lower Mississippian sedimentary rocks in the Williston Basin as recording a reorientation of the seaway as an opening developed to the west through the Central Montana trough, possibly because of tilting of the Transcontinental arch and the development of a shear system in central Montana. Major regression in the Alberta Basin began in Famennian or early Kinderhookian time (latest Devonian or earliest Mississippian) (Wilson, 1975). Following the late Famennian or early Kinderhookian regression, an advancing Early Mississippian seaway deposited a clastic sequence that underlies the Madison Limestone in the Powder River Basin area (fig. 38).

- South of the Transcontinental arch, along the Ouachita shelf, is a transgressive sequence similar to that in the Powder River Basin area. In southeastern Nebraska, a series of dark shales, which may span the Devonian-Mississippian boundary, is present at the base of the Kinderhookian Provincial Series. These shales grade upward into a series of shallow-water limestones depositionally similar to the Lodgepole and Mission Canyon Limestones sequence in the Powder River Basin area. The middle Meramecian regression that ended deposition of stratigraphic sequence four and initiated deposition of stratigraphic sequence five (fig. 2, 35) is not as apparent south of the Transcontinental arch, where limestone deposition continued, at least intermittently, for the remainder of Mississippian time. Farther to the south, along the Ouachita margin, Osagean through Chesterian siliceous shale overlies the Devonian to Lower Mississippian succession. The shale contains thick slump masses that were apparently derived from the northern shelf and turbidite, tuff, and tuffaceous sandstone. Much of the sediment transported by turbidity currents apparently was derived from the rising Appalachian highland to the northeast, and the tuffaceous rocks may have been derived from an arc to the south (Morris, 1974).

\section{Paleobiological Controls on Sedimentation}

Silurian through latest Devonian reefs represent the maximum development of Paleozoic reef growth in terms of variety of structures, geographic and paleotectonic setting, and diversity of reef-forming taxa. Metazoans, sponges, bryozoans, calcareous red and green algae, brachiopods, and pelmatozoans increased in number and variety throughout the Silurian until the latest Devonian. Ramose and encrusting bryozoans are the primary skeletal components of Ordovician and Silurian mounds, whereas corals were the dominant component in the Devonian (James, 1983). Stromatoporoids were most extensively developed in the Devonian, commonly in the upper parts of the reefs, and tabulate corals dominated downslope environments in more turbid waters. Solitary rugose corals were best adapted to soft substrates, but colonial rugose corals also developed a wide variety of morphologies. Calcareous algae were still present as encrusting Renalcis in shelf-margin reefs and Solenopora and Parachaetetes as nodules. Flanking beds in reef and reef mounds are made up predominantly of debris from pelmatozoans (crinoids, blastoids, and cystoids) and brachiopods, but crinoid flank beds are not as abundant in Devonian buildups as in Silurian (James, 1983).

Many important reef-building groups became extinct near the end of the Late Devonian. By the end of Frasnian time, many marine invertebrates that populated the sea floor, primarily the coralline skeletal and reef builders, had vanished. The number of genera of stromatoporoids was greatly reduced, rugose corals were dramatically altered, and tabulate corals became extinct. Brachiopods underwent considerable extinction and were never again as diverse (James, 1983, p. 412).

In Early Mississippian time, pelmatozoans and bryozoans replaced corals and stromatoporoids. Few, if any, reefbuilding taxa survived. A variety of new carbonate-producing organisms appeared during Mississippian and Pennsylvanian time. Important taxa include phylloid calcareous algae (Archaeolithophyllum, Eugoniophyllum, and Ivanovia) and Tubiphytes. Other important forms are Opthalmidid-Calcitornellid tabular foraminifer, small dendroid stromatoporoids (for example, Komia), and the encrusting coralline alga(?) Archeolithoporella. Most Mississippian carbonate buildups are in and around the margins of intracratonic basins as Waulsortian(?) mud mounds, which indicate clear, open-marine settings. Waulsortian mounds, lenticular mounds of 50-80 percent massive, vaguely clotted, peloid lime mudstone and only scattered fragments of crinoids and bryozoans, are the dominant Mississippian carbonate buildups. Waulsortian facies are present in the Kinderhookian and Osagean Lodgepole Limestone in the Big Snowy Mountains, west of the apex of the Central Montana high, and in the Bridger Range of Montana (Cotter, 1965; Smith, 1972); irregular bodies of limestone in the Banff Limestone of Alberta on Grotto Mountain also probably represent Waulsortian mounds (Wilson, 1975). Waulsortian mounds also are present along the Cedar Creek anticline, just northeast of the present-day Powder River Basin. In Late Mississippian time, isolated corals became locally important constituents in bioherms (James, 1983, p. 412).

\section{Stratigraphic Units of Sequence Three}

The third stratigraphic sequence within the Powder River Basin is primarily of Late Devonian age (figs. 2, 35, 42 ) and is principally dolomite but contains some limestone, evaporite, and terrigenous clastic rocks. Pre-Late 


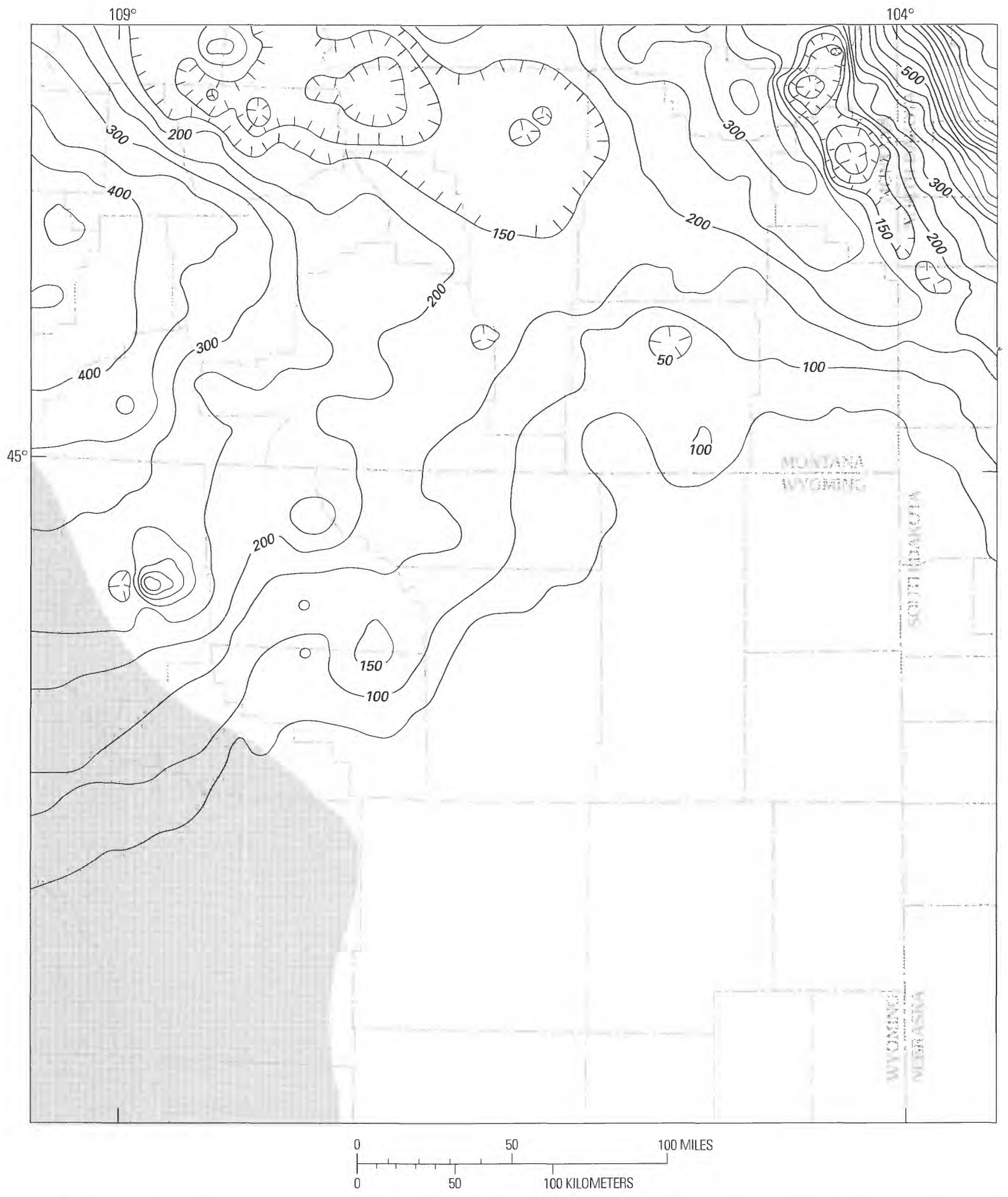

Figure 42. Isopach map of stratigraphic sequence three (Devonian, undifferentiated). Contour interval $50 \mathrm{ft}(15 \mathrm{~m})$; zero-isopach line not mapped. Based on 439 wells; gridded on an approximately 7 mi by $7 \mathrm{mi}$ grid $(12 \mathrm{~km}$ by $12 \mathrm{~km})$. Screened area in the southwestern part of the map area is an area of very limited control. Data modified from Downey (1982). Map area shown in figure 3. 
Devonian erosion removed the once extensive carbonate sheets of the Middle Ordovician through Silurian sequence that had covered a large part of the Transcontinental arch. Middle Devonian rocks are missing from most of the Powder River Basin area (fig. 35), although Middle and Upper Devonian rocks in adjacent areas, especially the Hay River, Alberta, and Williston Basins, underlie the prairie provinces of Canada (Wilson, 1975) and are present in the Williston Basin part of the study area and in parts of western Montana.

Regional onlap of basal Devonian rocks indicates that transgression began in a small depression in center of the Williston Basin and gradually expanded outward across the entire basin (Magathan, 1987). Middle Devonian rocks are important petroleum reservoir rocks in the Williston Basin (see, for example, Gendzwill and Wilson, 1987; Rosenthal, 1987).

In the northeastern Powder River Basin area, the Lower Devonian Beartooth Butte Formation (Benson, 1966) probably represents infilling of Silurian stream valleys formed by westward-flowing streams draining the Wyoming shelf. Dorf $(1933,1934 a, b)$ first recognized the Beartooth Butte Formation (fig. 35) in channel deposits at Beartooth Butte in the Absaroka Mountains, and discontinuous remnants of the formation are present in the central Bighorn Mountains (Blackstone and McGrew, 1954; Sandberg, 1961a). In Cottonwood Canyon (sec. 34, T. 57 N., R. 39 W.), along the northwest flank of the Bighorn Mountains, Blackstone and McGrew (1954) dated similar deposits in an east-west channel about $1,500 \mathrm{ft}(457 \mathrm{~m})$ long and $150 \mathrm{ft}(46 \mathrm{~m})$ thick as Early Devonian based on Protaspis and other invertebrates. Other fossils from the formation include the conodont genera Icriodus and Apathognathus and the spores Sporangites(?). The formation consists of a basal conglomerate containing white porcellaneous dolomite boulders in a red, silty to sandy matrix that is overlain by red calcareous siltstone. The red siltstone grades upward into gray and greenish siltstone with local sandstone lenses. The upper part of the formation contains lenses of coarse quartz sandstone that includes some well-rounded and frosted grains. Dolomite of the Jefferson Formation (fig. 35) overlies the channel deposits. Blackstone and McGrew (1954) correlated the Cottonwood Canyon section of the Beartooth Butte Formation with the type section at Beartooth Butte, Wyoming (Dorf, 1934a, b), and sections at Clarks Fork Canyon (Hughes, 1933) and Little Dryhead Canyon, as well as with the base of the Devonian System at Big Goose Creek (described by Tomlinson, 1917).

The Beartooth Butte Formation (fig. 35) generally is present west of the Wasatch hinge line (fig. 1) in Utah and southern Idaho and within an embayment that extends from south-central Montana into northwestern Wyoming (Benson, 1966, fig. 3). The Beartooth Butte is equivalent to the Water Canyon Formation (Williams, 1948) of southern Idaho and northern Utah (Benson, 1966). The Beartooth Butte and Water Canyon Formations are the nearshore detrital faces of most of the Sevy Dolomite of Utah and Nevada (Osmond, 1962; Benson, 1966).

The basal Devonian section in the Williston Basin in Canada, the Ashern Formation (fig. 35) (Bluemle and others, 1981, 1986), is a diachronous, subaqueously reworked karst residue (terra rossa) and is probably an age equivalent of the Beartooth Butte Formation (Sandberg and Hammond, 1958; Sandberg, 1965). Devonian rocks containing Eifelian (lower Middle Devonian) fossils succeeded the Ashern Formation (Lobdell, 1984) as the earliest Winnipegosis sea transgressed across the basin.

\section{Middle Devonian Rocks}

Middle Devonian rocks are not present in the Powder River Basin area, but in the Williston Basin Middle Devonian rocks are a cyclic sequence of shallow-water deposits including fossiliferous carbonate rocks, shaly carbonate or shale, and evaporite, including some halite in the basin center ("Prairie salt" of subsurface usage; Peterson, 1984; Wilson, 1955, 1967). In western Montana, Middle Devonian sedimentary cycles grade upward from silty to shaly carbonate at the base, through massive, porous, dolomitized, stromatoporoid and crinoidal limestone, to dolomite and solution breccia or anhydrite at the top. The section is more calcareous and less porous toward the interior of the Williston Basin and is as much as 50 percent or more limestone in the basin center (Peterson, 1984). In the central part of the Williston Basin, Middle and Upper Devonian rocks are more than $1,000 \mathrm{ft}(300 \mathrm{~m})$ thick (Peterson, 1984).

Andrichuk (1951), Baillie (1955), Sandberg and Hammond (1958), Sandberg (1961b), Kent (1964), Benson (1966), Wilson (1967), Sandberg and Mapel (1967), Baars (1972), Peterson (1984), and Peterson and MacCary (1987) gave regional summaries of the Devonian System.

\section{Upper Devonian Rocks}

Within the study area, Upper Devonian rocks of stratigraphic sequence three are 0-330 $\mathrm{ft}(0-101 \mathrm{~m})$ thick (fig. 42). They include the Darby Formation within the Powder River Basin (Wyoming Geological Association Technical Studies Committee, 1965; Kent and others, 1988) and also may include rocks of the Jefferson and Duperow Formations in the Central Montana uplift area and rocks of the Souris River, Duperow, Birdbear, and Three Forks Formations in the Cedar Creek anticline area (Ballard and others, 1983) (fig. 35).

Upper Devonian rocks are preserved in a trough that developed between the Wyoming shelf and the Wyoming arch (figs. 5, 36) (Benson, 1966). The Wyoming shelf 
was onlapped from the north through the Williston Basin and from the west through the trough between the Wyoming shelf and the Wyoming arch. Offlapping, possibly accompanied by minor erosion, due to eustatic sea-level fall or uplift of the Wyoming shelf relative to the western trough or both, was responsible for the hiatus at the base of stratigraphic sequence four (figs. 2,35 ) on the Wyoming shelf.

The Souris River Formation is contemporaneous with the Maywood; however, the Souris River probably represents deposition during a southward transgression from Canada into the Williston Basin, and the Maywood may represent eastward transgression from the Cordilleran miogeocline (Benson, 1966). The Maywood and Souris River probably were deposited in stream valleys cut into the preMaywood erosional surface, and the distribution of the Maywood-Souris River is roughly coincident with that of the Lower Devonian Beartooth Butte Formation (Sandberg, 1965; Benson, 1966).

In the northern part of the Powder River Basin, sandstone, red shale, and dolomite of the Upper Devonian Darby Formation mark the influx of clastic sediments, probably from eastern source areas along the Transcontinental arch (figs. 36, 37). Most of the Wyoming shelf, however, was exposed during Devonian time (Houston, 1969).

All rocks within the study area that have been assigned latest Devonian ages by other workers, except for a unit named the Fremont Canyon Sandstone in the Alcova, Wyoming, area (Sando and Sandberg, 1987), are included in stratigraphic sequence four (Mississippian) (figs. 2, 35). These include the basal part of the Guernsey Formation in the Hartville area (Love, Denson, and Botinelli, 1949; Love, Henbest, and Denson, 1953; Sandberg and Klapper, 1967) (fig. 1), the basal part of the Englewood Formation in the Black Hills (Klapper and Furnish, 1963), the basal part of the Madison Limestone in the Bighorn Mountains, the Sappington Member of the Three Forks Formation to the west, and the Bakken Formation to the north (Sandberg and Klapper, 1967). Individual stratigraphic units within the Upper Devonian sequence are not shown on the cross sections (pls. 1, 2).

\section{Maywood, Jefferson, Souris River, and Duperow Formations}

The Maywood Formation (Benson, 1966; Baars, 1972) (figs. 35, 36) represents the initial deposits of the transgressing Late Devonian sea in west-central Wyoming, southwestern Montana, eastern Idaho, and northeastern Utah. The Maywood is laterally equivalent to the Souris River Formation in the Sweetgrass arch area (fig. 1), Williston Basin, and southern Saskatchewan. In the Williston Basin, the Souris River consists of several depositional cycles of fine clastic rocks grading upward to argillaceous and fossiliferous dolomite or limestone capped by dolomite or anhydrite (Sandberg and Hammond, 1958; Wilson, 1967; Peterson and MacCary, 1987).

The Upper Devonian (Frasnian and Famennian) Jefferson Formation (Group in the Williston Basin, Sandberg and Hammond, 1958, and Sandberg, 1965; southern Saskatchewan, Christopher, 1962; and Sweetgrass arch, Hurley, 1962, and Benson, 1966) overlies the Maywood Formation; it consists mostly of dark-colored carbonate rocks and records shallow-water nearshore environments (Wyoming Geological Association Technical Studies Committee, 1965). The Jefferson Formation extends as far south as northeastern Utah (Kindell, 1908; Tomlinson, 1917). The lower member of the Jefferson Formation and its lateral equivalent, the Duperow Formation of the Jefferson Group in northern Montana, North Dakota, and South Dakota (Baars, 1972), is more siliciclastic toward central Wyoming where limestone breccia, which is commonly associated with the detrital units, may be evaporite solution-collapse breccia (Benson, 1966). Cyclically repeated, thin, laterally persistent detrital beds are present throughout the lower member westward from central Wyoming to the miogeocline in Idaho and western Montana where they are thin and more difficult to recognize. The uppermost detrital unit of the lower member (unit A of Benson, 1966) is the thickest (8-24 ft, $2.4-7.3 \mathrm{~m}$ ) of these and is continuous from the Williston Basin to northeastern Utah. This interval is equivalent to the gray-green shale marker in northern Montana (Hurley, 1962). The large increase in the percentage of sand in the Jefferson Formation near the eastern erosional edge in central Wyoming suggests that the depositional edge was not much farther east. Crossbedded sandstone near the present edge may represent beach or dune deposits along the Late Devonian shoreline.

In northern Montana, North Dakota, and South Dakota, the Duperow Formation conformably overlies the Souris River Formation and consists of a cyclical carbonateevaporite sequence somewhat similar to that of the Souris River but more completely developed and containing abundant skeletal banks or mounds of stromatoporoids, tabulate corals, and other normal marine organisms (Peterson and MacCary, 1987). The Duperow Formation represents an inner shelf, lime mud-sabkha depositional environment that extended into South Dakota and Wyoming from the southern margin of the Alberta Basin. Each lime mud-sabkha cycle shoals upward. Faunal and sedimentary features show a progressive upward change through restricted marine carbonate to laminated evaporite of sabkha origin (Wilson, 1975).

The uppermost member of the Jefferson Formation is the Birdbear Member (fig. 35), a characteristically brown to light-brownish-gray, finely crystalline dolomite (Sandberg and Hammond, 1958; Christopher, 1962; Hurley, 1962; Sandberg, 1965; Benson, 1966). The upper several feet of the Birdbear are lighter colored and more coarsely 
crystalline, possibly because of solution and recrystallization during a slight emergence at the end of Birdbear deposition. The contact with the underlying lower member is abrupt, as is the contact with the overlying Three Forks Formation (Benson, 1966). Local thinning of the Birdbear suggests a minor hiatus following Jefferson deposition (Benson, 1966).

The Jefferson Formation thickens markedly west of the Wasatch hinge line (fig. 1) but is absent over the Lemhi arch (Tendoy Dome) because of depositional onlap (Benson, 1966, fig. 5). The Jefferson Formation thins southward toward central Utah and pinches out by depositional onlap over the ancestral Uinta arch, which may have been a western extension of the Transcontinental arch. An unconformity separates the Jefferson Formation in northern Wyoming and the Darby Formation in west-central Wyoming from the overlying Cottonwood Canyon Member of the Madison Limestone (Sandberg and Klapper, 1967). This unconformity is probably due to offlapping of sedimentation from the Wyoming shelf in latest Devonian time. The Jefferson Formation has been correlated with the lower limestone unit of the Devils Gate Limestone of Nevada and the base of the Chemungian Stage (upper third of Seneca Series or Frasnian Stage) in Pennsylvania and New York (Wilson, 1955; Benson, 1966).

\section{Three Forks Formation}

The Three Forks Formation (fig. 35) overlies the Birdbear with local unconformity in southwestern Montana and western Wyoming. The Three Forks Formation consists of marine and nonmarine red and green shale, siltstone, sandstone, and carbonate rocks and represents the final regressive phase of Devonian deposition. The Three Forks Formation consists of three members (McMannis, 1962; Sandberg, 1962, 1965) (in ascending order): the Logan Gulch, Trident, and Sappington Members. The Sappington Member, however, is disconformable on the Trident Member (Benson, 1966) and in the present report is included in the Mississippian sequence as a basal clastic unit. It is discussed as part of stratigraphic sequence four (figs. 2, 35). Most of the Wyoming shelf was exposed briefly at the close of Three Forks time (Peterson, 1984).

Logan Gulch and Trident Members

The Logan Gulch Member of the Three Forks Formation (fig. 35) consists mostly of solution-brecciated limestone and greenish shale (Sloss and Laird, 1947). The base of the member is silty and dolomitic shale, and a limestone at the top locally serves as a stratigraphic marker (Sandberg, 1965; Benson, 1966). The Logan Gulch Member has been assigned an earliest Famennian age (the evaporitic member of the Three Forks of Sandberg, 1963;
Benson, 1966). Sandberg (1963) included gray dolomitic limestone and silty dolomite at the base and nodular limestone at the top within the Trident Member. The Trident Member is missing in the east because of nondeposition, latest Devonian erosion, or both, and the remaining Three Forks is mainly equivalent to the Logan Gulch Member (Benson, 1966). Sandberg (1963) assigned the Trident Member a middle Famennian age.

Near its eastern erosional edge in southern Montana and northern Wyoming, almost the entire Three Forks Formation is composed of silty dolomite and dolomitic mudstone. Much of this facies is reddish except in the western Washakie Range, Wyoming, where the upper part is buff mudstone (Benson, 1966).

In southwestern Montana, just northwest of the northwestern corner of Wyoming, and in western Wyoming, southeastern Idaho, and northeastern Utah, just west of the Wasatch hinge line (fig. 1), an evaporite facies is present in the Logan Gulch Member. The surface exposure of this facies is evaporite-solution breccia that is generally argillaceous and has a calcareous matrix. Anhydrite is present in the subsurface of nearby basins. Evaporite in southwestern Montana is as thick as $100 \mathrm{ft}(30 \mathrm{~m})$ and has been traced into the upper part of the Potlatch Anhydrite on the present Sweetgrass arch, which was the center of a large evaporite basin in northwestern Montana. A second body of evaporite, which is as thick as $40 \mathrm{ft}(12 \mathrm{~m})$, is present along the Wyoming-Idaho State line in the Snake River and Salt River Ranges. The two large bodies of evaporite may have been continuous around the west side of the Tendoy Dome (Benson, 1966).

The evaporite facies grades eastward into a shaly dolomite facies that consists chiefly of greenish-gray dolomitic shale in the lower part and thin-bedded light-gray to buff and brownish-gray shaly dolomite having greenish shale partings in the upper part. Brecciation, mud cracks, ripple marks, intraclasts, and dolomite pseudomorphs after halite suggest that the shaly dolomite facies was evaporitic; however, the facies lacks the massive, highly brecciated appearance of the main evaporite facies farther west.

In west-central Montana, the green shale facies within the Trident Member is as thick as $250 \mathrm{ft}(76 \mathrm{~m})$ and consists of dark calcareous fossiliferous claystone that grades southeastward into purer carbonate rocks (McMannis, 1962). Thin tongues of clastic carbonate above and below the green shale intertongue eastward into dolomitic rocks. Medium- to dark-gray, very finely crystalline, dense limestone and dolomite, which are shaly and silty in most places, characterize the carbonate facies. The carbonate facies also continues southward along the Wyoming-Idaho State line and at the base of the Three Forks consists of a few feet of shaly or silty dolomite. Sand grains near the base of the Three Forks are more abundant south and eastward in Wyoming. A similar silty, shaly, and commonly variegated unit, called the Calmar red shale marker by 
Hurley (1962), is present at the base of the Three Forks in the Sweetgrass arch area (Benson, 1966).

\section{Beirdneau Formation}

The Beirdneau Formation (fig. 35) is the lateral equivalent of the Three Forks Formation in the miogeocline in northeastern Utah and southeastern Idaho (Benson, 1966). The Beirdneau Formation is medium-gray to pale-brown, dense, very finely crystalline dolomite, commonly shaly, silty and sandy. Hematite casts, mud cracks, and floating sand grains are common. Although two units of quartzitic sandstone are present in the lower half, sandstone is not the dominant rock type.

\section{Darby Formation}

In west-central Wyoming, where the Birdbear Member is missing by depositional offlap, pre-dark shale erosion, or both, the unit correlative to the lower member of the Jefferson Formation is called the Darby Formation (fig. 35). The Darby Formation consists of dark, fine- to medium-crystalline dolomite ledges separated by less resistant beds of shale, mudstone, siltstone, sandstone, detrital carbonate, and very finely crystalline carbonate. Pebbly and carbonaceous channel-fill deposits are locally present at the base of the Darby (Benson, 1966).

\section{Stratigraphic Units of Sequence Four}

Kinderhookian, Osagean, and early Meramecian rocks comprise stratigraphic sequence four, the most widespread of the Cambrian through Mississippian stratigraphic intervals in the northern Great Plains region (figs. 35, 38-40, $42,43,45$ ). Stratigraphic sequence four is made up primarily of a series of clean carbonate rocks (fig. 45); the Madison Limestone and equivalents make up most of the Mississippian rocks in the study area, and the Big Snowy Group and equivalents are only important in the northern part of the area (compare figs. 43 and 44).

Kinderhookian (Early Mississippian) transgression onto the Wyoming shelf (fig. 38 ) reestablished normal marine carbonate deposition (Kent, 1972) as a carbonate platform onlapped the shelf from the east (Rose, 1976) and probably from the north and west as well. The Madison Limestone of the Bighorn Mountains and western Powder River Basin and the Englewood Formation and Pahasapa Limestone of the Black Hills and eastern Powder River Basin were deposited on this carbonate platform. Initial Mississippian deposits of the Powder River Basin area are clastic and clastic-rich-carbonate rocks. Clastic deposition within the proto-Sweetwater trough probably continued until carbonate deposition reached the southern part of the basin area in the late Kinderhookian or early Osagean (Craig and Connor, 1979).

The Lodgepole Limestone represents deposition in upward-shoaling sedimentary cycles (Wilson, 1975) wherein normal marine units comprise the early part of each cycle and are replaced upward by restricted marine facies and, in some examples, ultimately by evaporite (Wilson and Jordan, 1983). The Mission Canyon Limestone represents one of a series of regressive cycles of deposition in the Williston Basin during Mississippian time (Inden and Moore, 1983). Each cycle of the Mission Canyon Limestone has a somewhat unusual set of subfacies that characterizes it, but along the Mississippian basin all margins contain a barrier system, carbonate-mud- and evaporitefilled lagoon, and low-energy offshore carbonate mud. The cycles formed in an environmental setting very similar to the Persian Gulf Coast (Purser and Evans, 1973), and presumably a broad sabkha extended outward from the basin margins. Following Mission Canyon deposition, a middle or late Meramecian hiatus and progradation led to deposition of the Darwin Sandstone Member of the Amsden Formation and corresponds to a major middle or late Meramecian sea-level drop on the sea-level curves of Vail and others (1977) (E.K. Maughan, 1987, oral commun.).

Stratigraphic sequence four includes (in ascending order) a basal clastic unit and its lateral equivalents (including the Cottonwood Canyon Member of the Lodgepole Limestone in southern Montana and of the Madison Limestone in northern and west-central Wyoming, the Englewood Formation in the Black Hills, the Bakken Formation in the Williston Basin, and the Sappington Member of the Three Forks Formation in western Montana), the Lodgepole Limestone, and the Mission Canyon Limestone of the Madison Group (and lateral equivalents, including the Pahasapa Limestone in the Black Hills) (fig. 35 ). In the northern and eastern parts of the study area, the Madison Group also includes the Charles Formation. Stratigraphic sequence four is predominantly limestone and dolomite, although it contains evaporite or evaporite solution breccia, especially in the Charles Formation. The name Madison Limestone is used in the southern part of the area where the Lodgepole and Mission Canyon generally are not differentiated. The thickness of sequence four in the study area ranges from 0 to $1,400 \mathrm{ft}(0-427 \mathrm{~m})$.

In addition to the lithostratigraphic subdivisions of the Madison in Wyoming, Peterson (1984) subdivided the Mississippian section using a chronostratigraphic marker horizon system. The base of marker M1 is about at the Devonian-Mississippian boundary; interval M1 to M3 is about Kinderhookian; interval M3 to M7 is lower Osagean; interval M7 to M8.5 is middle Osagean; interval M8.5 to M12 is upper Osagean; and interval M12-Mc is roughly Meramecian. Peterson's (1984) marker horizons were used in the present study and are shown on the cross sections (pls. 1, 2). 


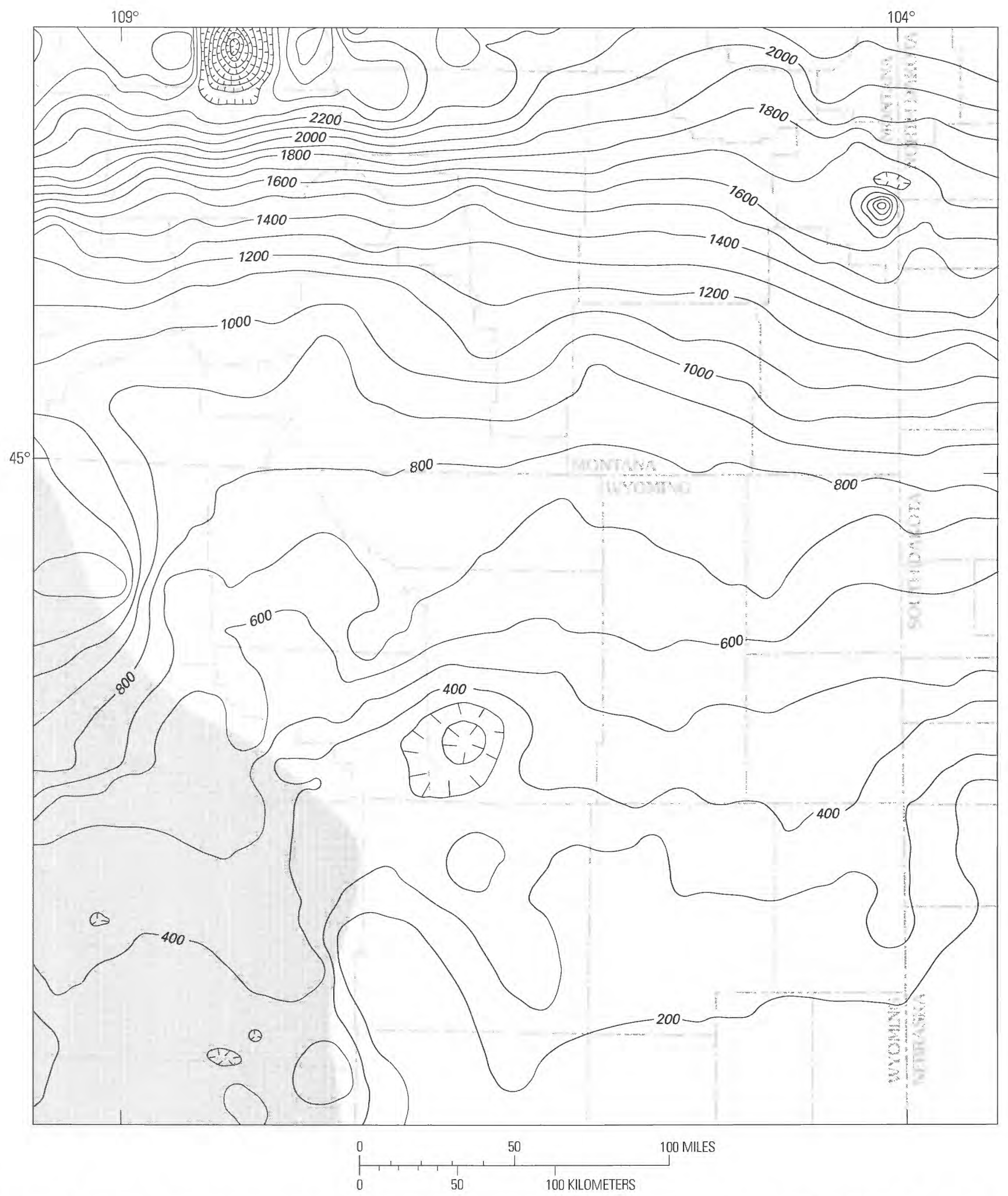

Figure 43. Isopach map of stratigraphic sequence four (older Mississippian rocks). Contour interval $100 \mathrm{ft}(30.1 \mathrm{~m})$. Based on 438 wells; gridded on an approximately $7 \mathrm{mi}$ by $7 \mathrm{mi}$ grid $(12 \mathrm{~km}$ by $12 \mathrm{~km}$ ). Screened area in the southwestern corner of map area is an area of very limited control. Data modified from Downey (1982). Map area shown in figure 3. 


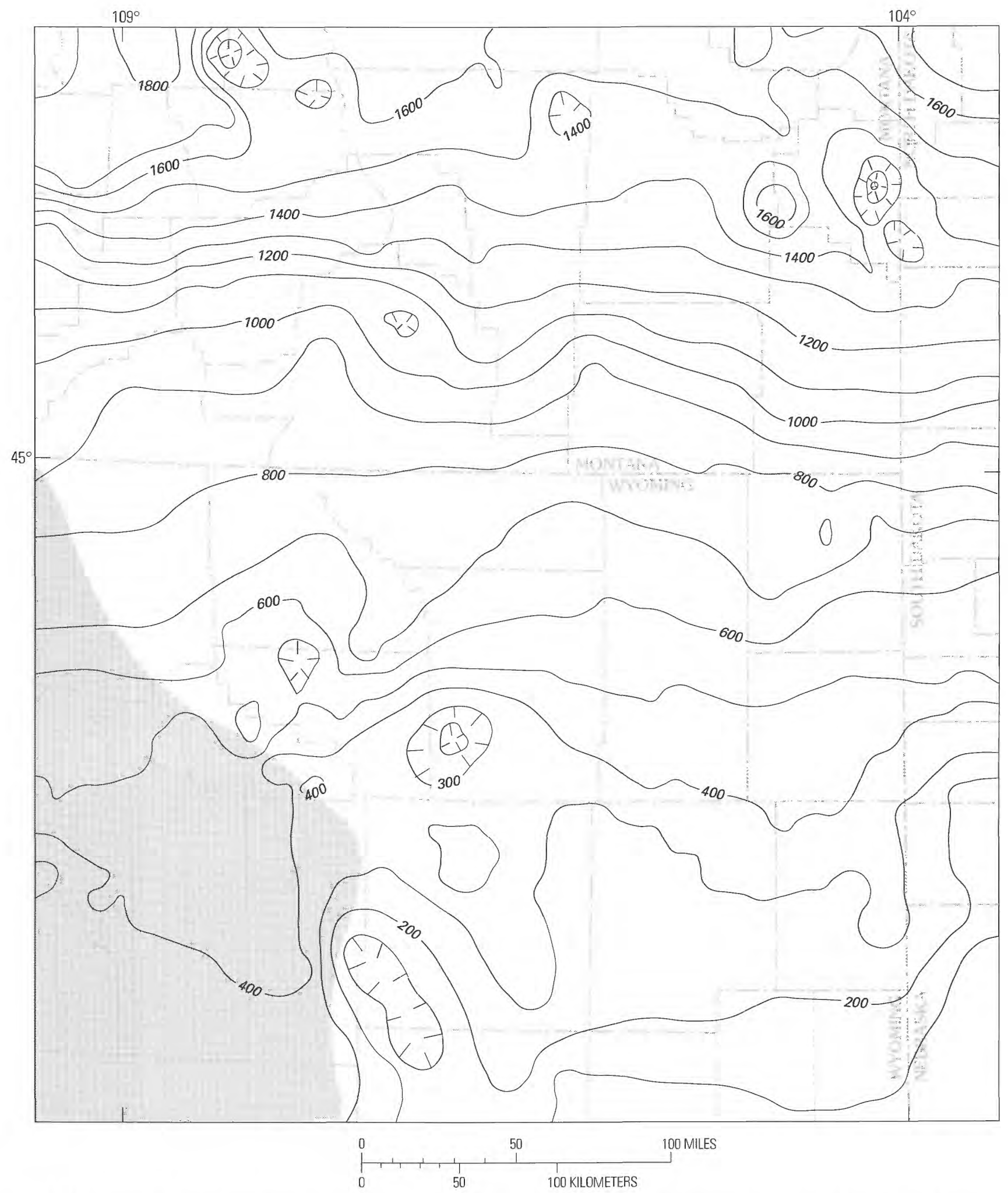

Figure 44. Isopach map of stratigraphic sequences four and five, combined. Contour interval $100 \mathrm{ft}(30.1 \mathrm{~m})$. Based on 384 wells; gridded on an approximately $15 \mathrm{mi}$ by $15 \mathrm{mi}$ grid $(24 \mathrm{~km}$ by $24 \mathrm{~km})$. Map area shown in figure 3 . Screened area in the southwestern corner of the map area is an area of very limited control. Data modified from Downey (1982). Map area shown in figure 3. 
Andrichuk (1951, 1955), Gries and Mickelson (1964), Roberts (1979), Sando (1967, 1974, 1976a, b, 1978), Craig (1972), Rose (1976), Sheldon and Carter (1979), Smith and Gilmour (1979), Peterson $(1978,1984)$, Brown and others (1982, 1984), Peterson and MacCary (1987), and Carlson and LeFever (1987) summarized stratigraphy of the Madison Group. Sandberg and Klapper (1967) summarized stratigraphy of the Cottonwood Canyon Member of the Madison and Lodgepole Limestones, and Dow (1974), Meissner (1978), Peterson (1984), Peterson and MacCary (1987), Thrasher (1987), and Holland and others (1987) summarized stratigraphy of the Bakken Formation.

\section{Basal Clastic Unit in the Powder River Basin Area}

In the Powder River Basin area the oldest unit of stratigraphic sequence four is a clastic deposit (figs. 2,35 ) that is disconformable above equivalents of the Upper Devonian part of the Three Forks Formation in the northwestern part of the area and above older rocks throughout the remainder of the area. The clastic unit at the base of stratigraphic sequence four is thickest in a trough trending northeast across western Wyoming (fig. 46) and coincident with the erosional edge of the Birdbear and Three Forks (Benson, 1966). In the Powder River Basin area, the clastic sequence is thickest adjacent to a northwest-trending spur on the northwest flank of the Transcontinental arch (pl. 1, cross section $B-B^{\prime \prime}$ ) north of the Laramie Mountains.

The Bakken Formation, Paine Member of the Lodgepole Limestone, Exshaw Formation, Leatham Formation, Sappington Member of the Three Forks Formation, Englewood Formation of the Black Hills, lower part of the Guernsey Formation in the Hartville uplift, and possibly the uppermost Milligen Formation or the lower part of the Little Copper Formation of Paull and Gruber (1977) are all considered at least partial time-transgressive stratigraphic equivalents of the basal clastic unit in the Powder River Basin area (fig. 35). The basal clastic unit is time transgressive throughout its extent. In the Black Hills, the Englewood Formation is as thick as $90 \mathrm{ft}(27 \mathrm{~m})$ in the subsurface and is $18-54 \mathrm{ft}(5.5-16 \mathrm{~m})$ thick at outcrops (Sandberg and Mapel, 1967). In the northern Wind River Mountains, Absaroka Range, Beartooth Mountains, and westward in Wyoming and Montana, the Sappington Member of the Three Forks Formation is as thick as $100 \mathrm{ft}$ (30 m) (Sandberg and Mapel, 1967).

The age of the base of sequence four cannot be determined with certainty. The oldest rocks of the sequence, however, probably are Early Mississippian (Kinderhookian) in age in the northern part of the study area. The basis of this assignment is principally the general conformity of these units with the overlying sequence, their position relative to physical stratigraphic markers (Peterson, 1984), and reevaluation of paleontological evidence for previous age assignments (also see Maughan, 1963). In the southern part of the study area the M3 marker (roughly the Kinderhookian-Osagean boundary) is at the base of the sequence (pls. 1,2 , cross sections $B-B^{\prime}, C-C^{\prime}-C^{\prime \prime}, D-D^{\prime}$ ), and an Early (but not earliest) Mississippian age is assumed for the base. Thus transgression of the Madison sea probably began in early Kinderhookian time and continued until at least late Kinderhookian or early Osagean time when carbonate deposition lapped onto the northern edge of the Transcontinental arch in the area of the present-day Laramie Mountains.

In the southern part of the Powder River Basin, Thomas (1951) assigned the clastic sequence to the Madison Limestone and dated it as Kinderhookian. He based the age assignment on Spirifer centronatus from well core (Ohio Oil No. 4 Government Well at Hatfield, Wyoming, T. 19 N., R. 88 W.), Camarotoechia sp. near the top of the conglomeratic sandstone near the Seminoe Reservoir and in limestone directly overlying the clastic sequence near Marshall, Wyoming, and a shark's tooth from the conglomeratic sandstone on the southern flank of the Seminoe Mountains. In the Laramie Range, Maughan (1963) assigned a late Kinderhookian age to the clastic sequence based on Chonopectus fischeri reported by Agatston (1954), the data of Thomas cited above, many unpublished reports of fossils occurrences, and physical stratigraphic evidence. Maughan (1963) also showed that the clastic and carbonate facies intertongue. Armstrong (1958) questioned the identification of $S$. centronatus from the Mississippian sections of the western United States and suggested that the misidentified specimens are a younger ranging species, implying that the basal Madison in southcentral Wyoming could be younger than early Kinderhookian. Peterson (1984) also assigned the unit an Early Mississippian age based on stratigraphic correlations, and I agree with his conclusions.

Sandberg (1963) correlated a "dark shale" of western Wyoming and southern Montana with the Englewood Formation of the Black Hills (Sandberg, 1963) and believed the unit to be disconformable beneath the Madison in northern Wyoming and southern Montana. He stated that the dark shale unit is a partial time equivalent to the Sappington Member but separated from it by a regional unconformity (Sandberg, 1963, fig. 64.2). Klapper (1966) assigned the Sappington Member to the uppermost Upper Devonian based on conodonts from the Sappington in the Bridger Range but noted neither the position of the sample nor the condition of the specimens. Sandberg and Klapper (1967, p. B10-11) assigned the Sappington Member a Late Devonian and Early Mississippian age; the Devonian age was based primarily on the lack of diagnostic Mississippian forms and on the dismissal of Mississippian forms that were present as the result of "stratigraphic leakage." 


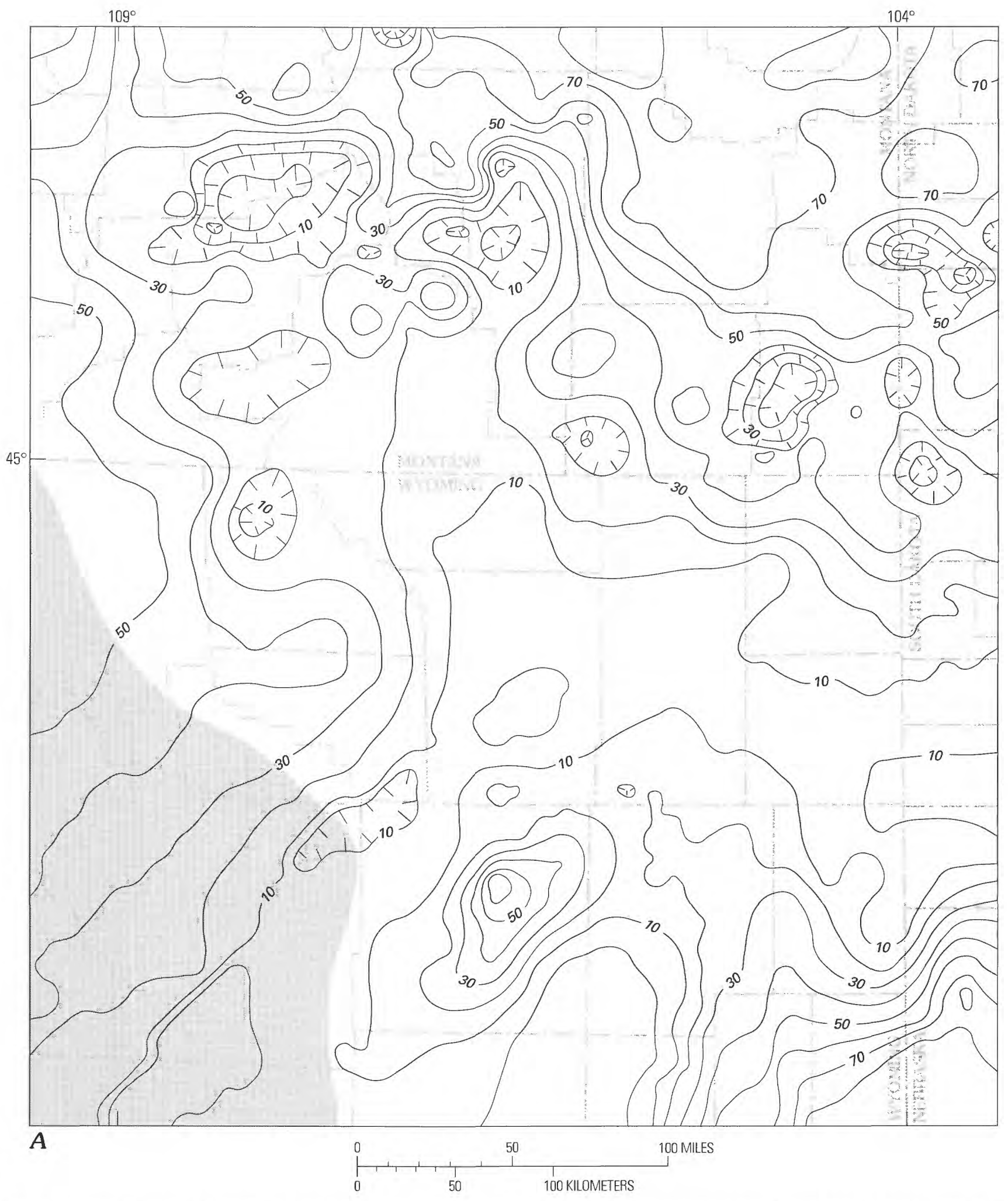

Figure 45. Lithology of the total Madison Limestone (Group) interval of stratigraphic sequence four. Based on 272 wells; gridded on an approximately $7 \mathrm{mi}$ by $7 \mathrm{mi}$ grid $(12 \mathrm{~km}$ by $12 \mathrm{~km})$. Map area shown in figure 3 . Screened area in the southwestern corner of map area is an area of very limited control. Data from Downey (1982). A, Percent limestone (contour interval 10 percent). 


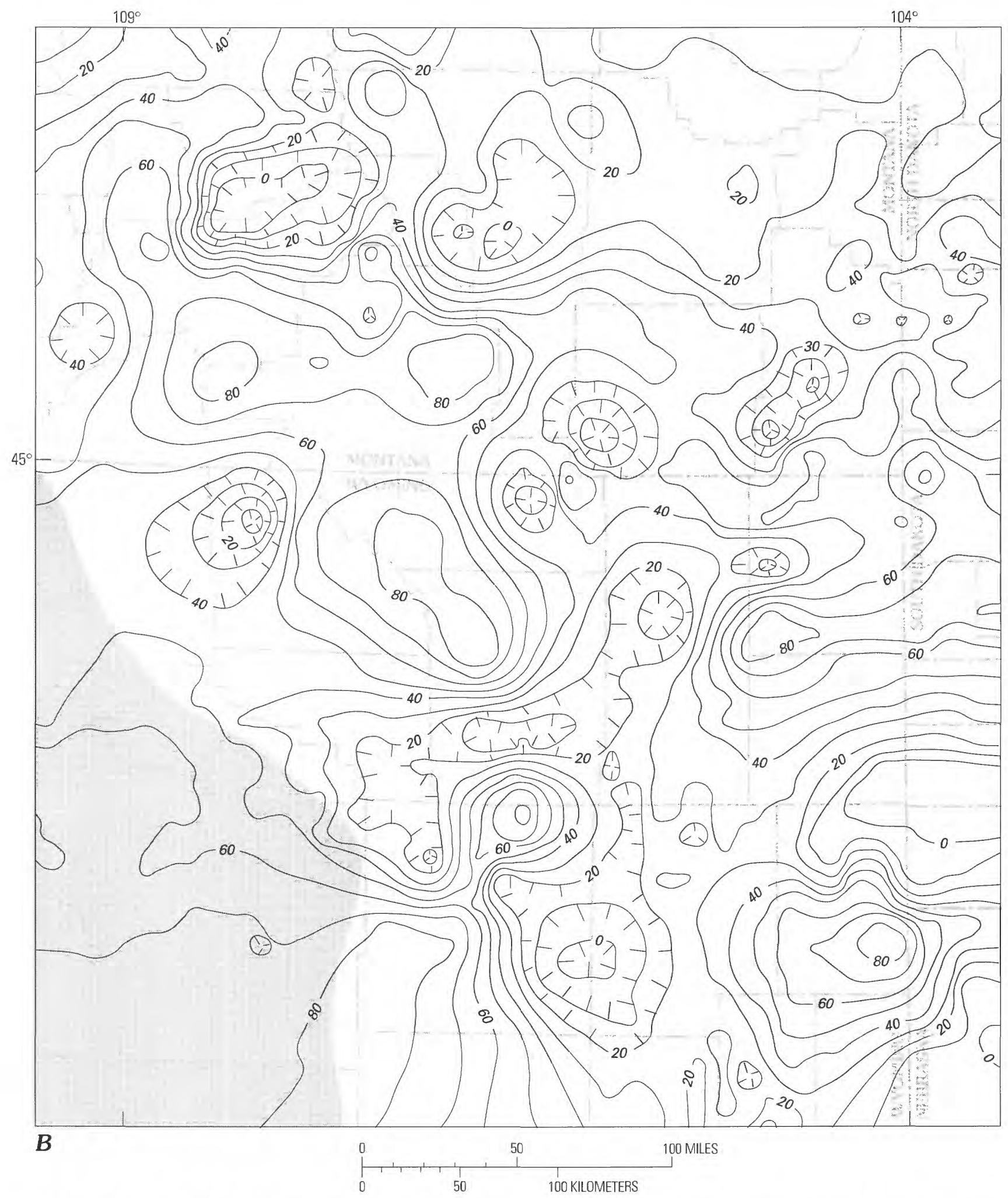

Figure 45 (continued). Lithology of the total Madison Limestone (Group) interval of stratigraphic sequence four. B, Percent dolomite (contour interval 10 percent). 


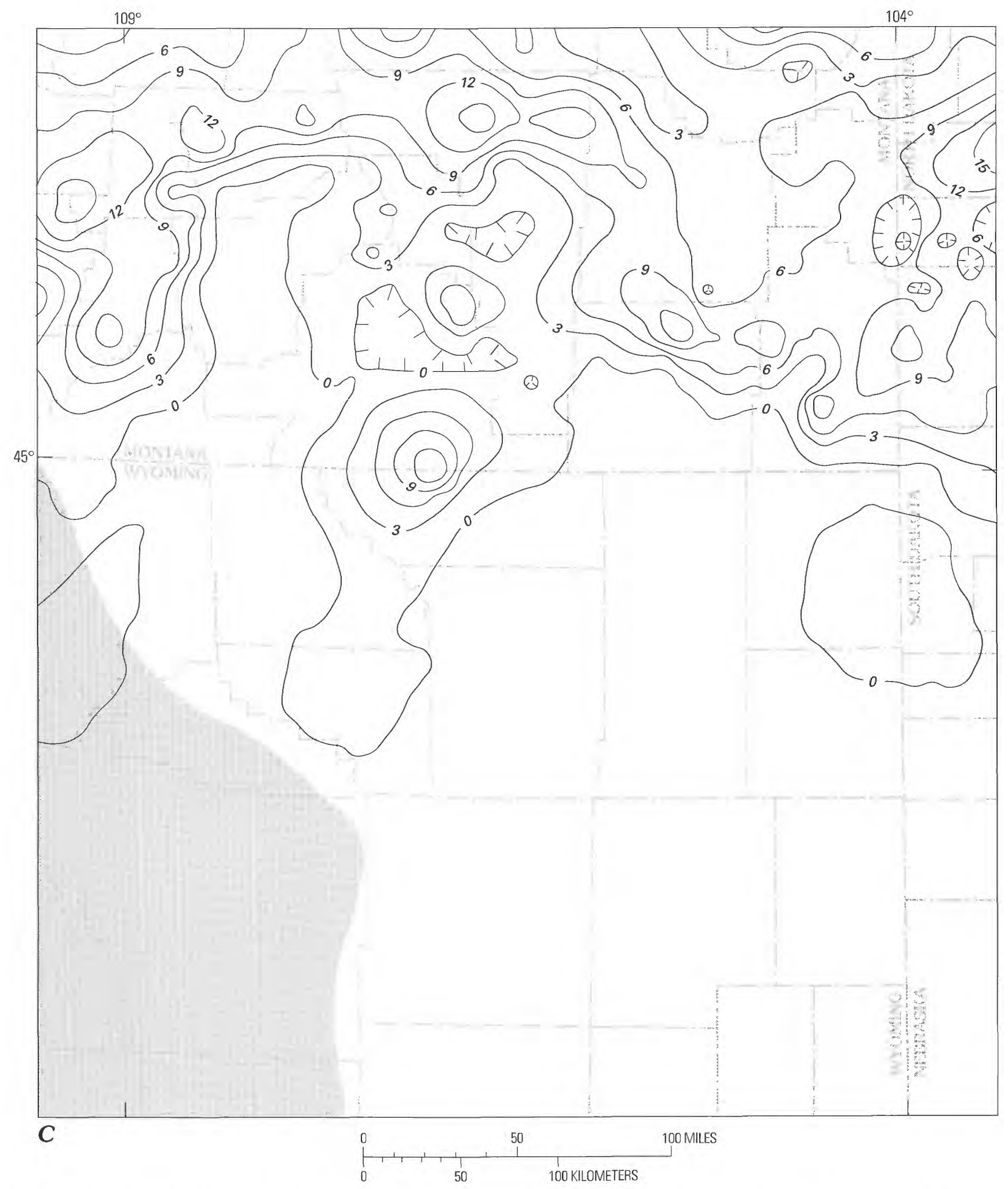

Figure 45 (continued). Lithology of the total Madison Limestone (Group) interval of stratigraphic sequence four. $C$, Percent evaporitic rock (contour interval 3 percent). 


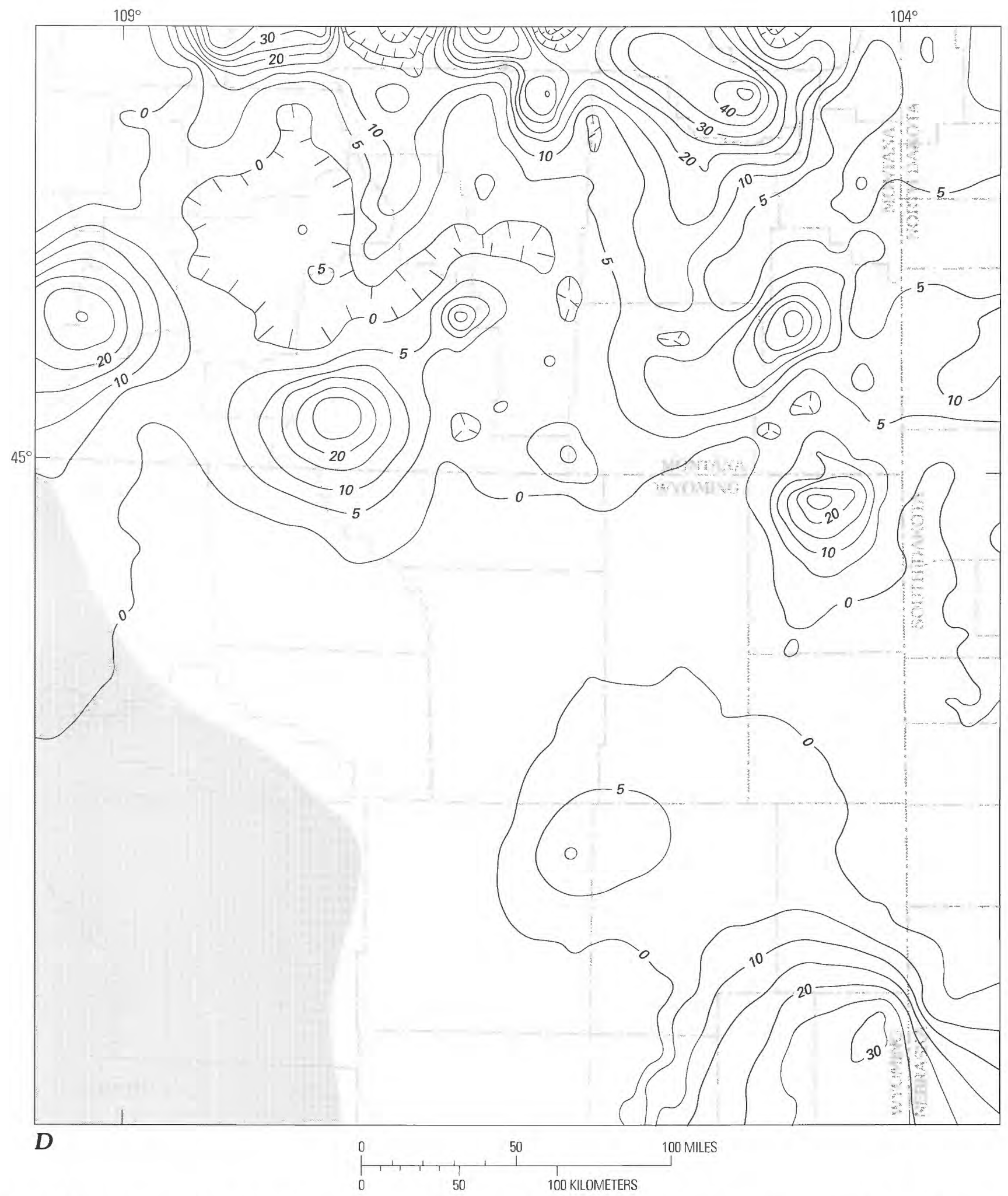

Figure 45 (continued). Lithology of the total Madison Limestone (Group) interval of stratigraphic sequence four. D, Percent bioclastic carbonate rock (contour interval 5 percent). 


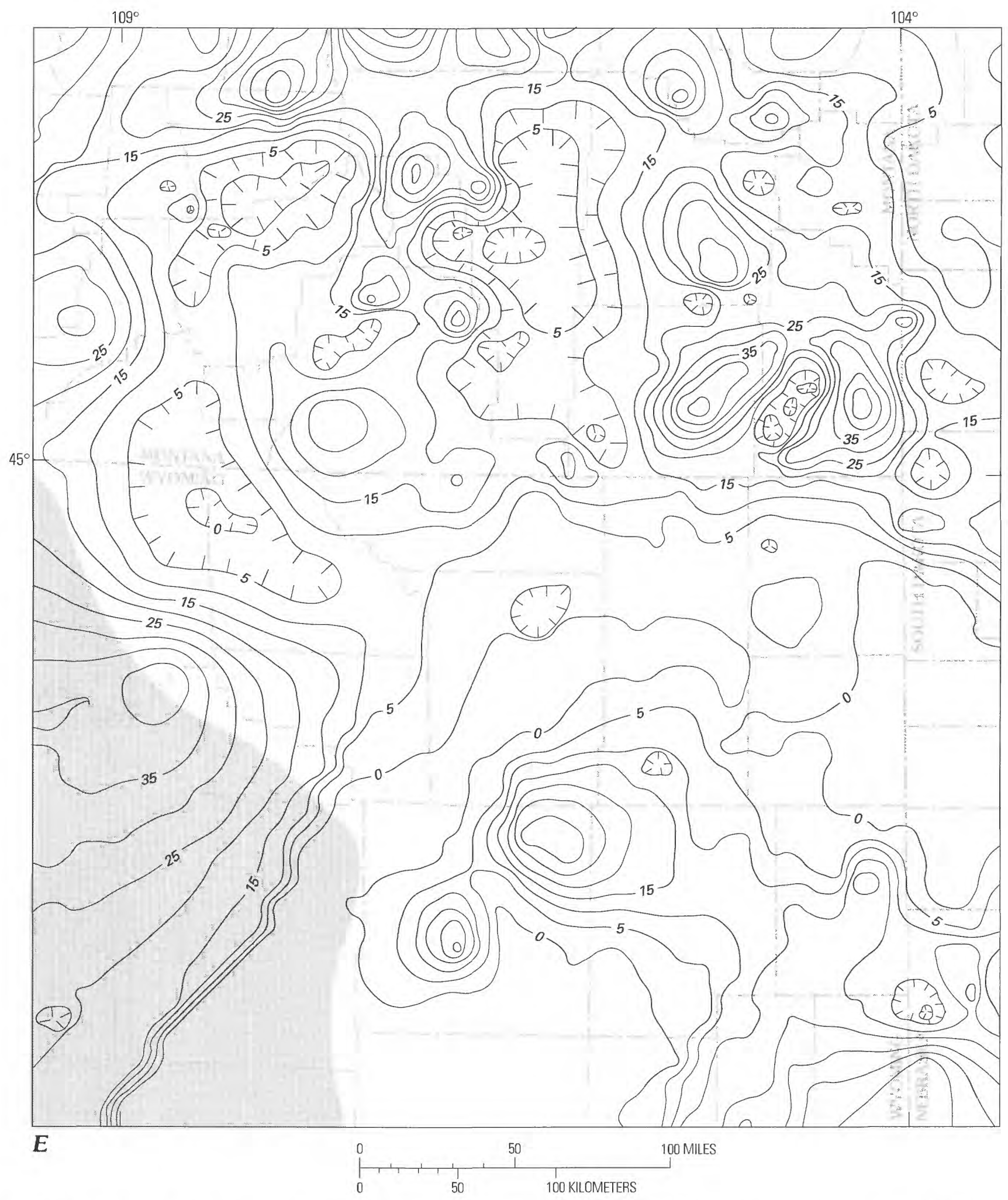

Figure 45 (continued). Lithology of the total Madison Limestone (Group) interval of stratigraphic sequence four. E, Percent oolitic carbonate rock (contour interval 5 percent). 


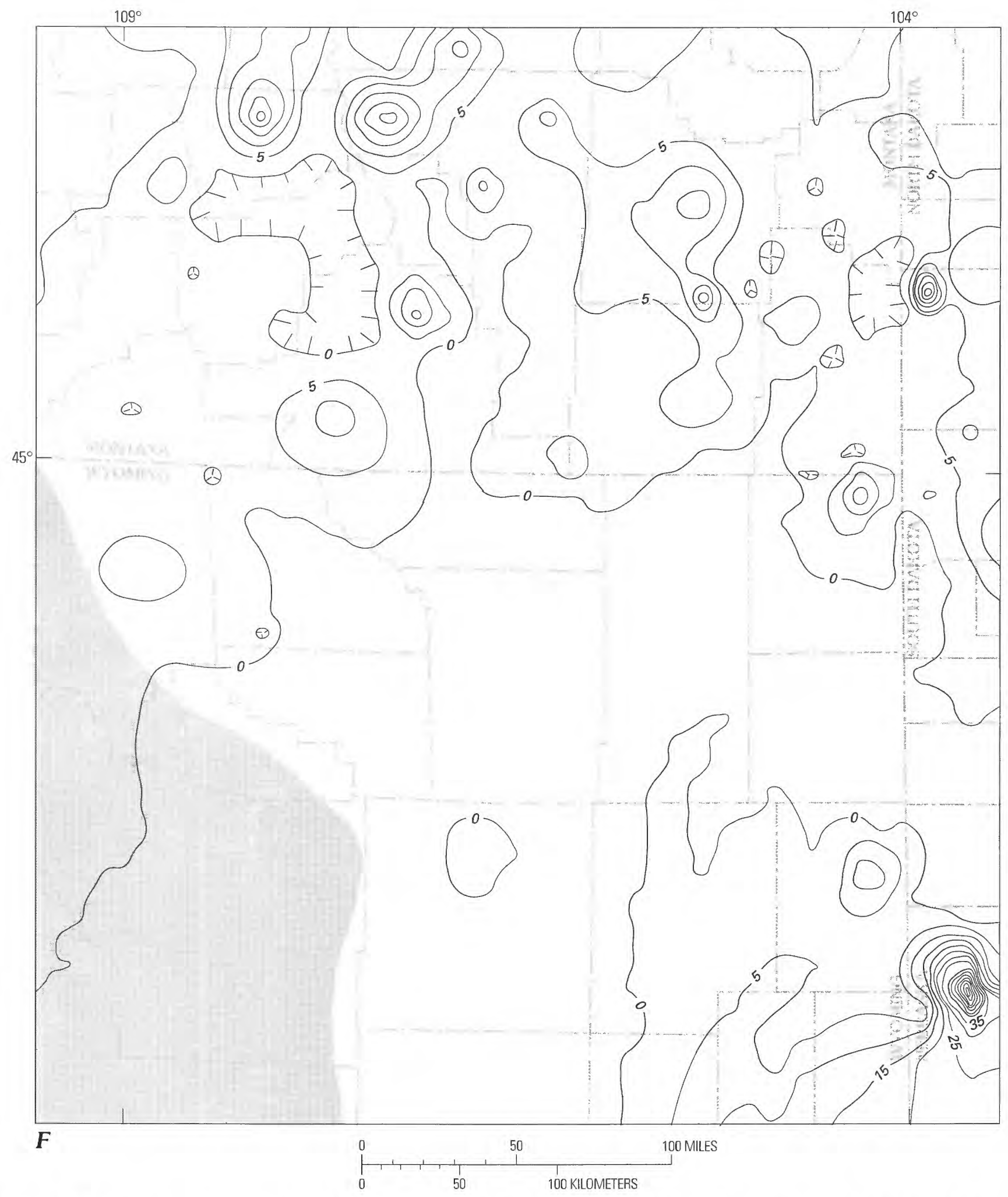

Figure 45 (continued). Lithology of the total Madison Limestone (Group) interval of stratigraphic sequence four. F, Percent algally derived carbonate rock (contour interval 5 percent). 


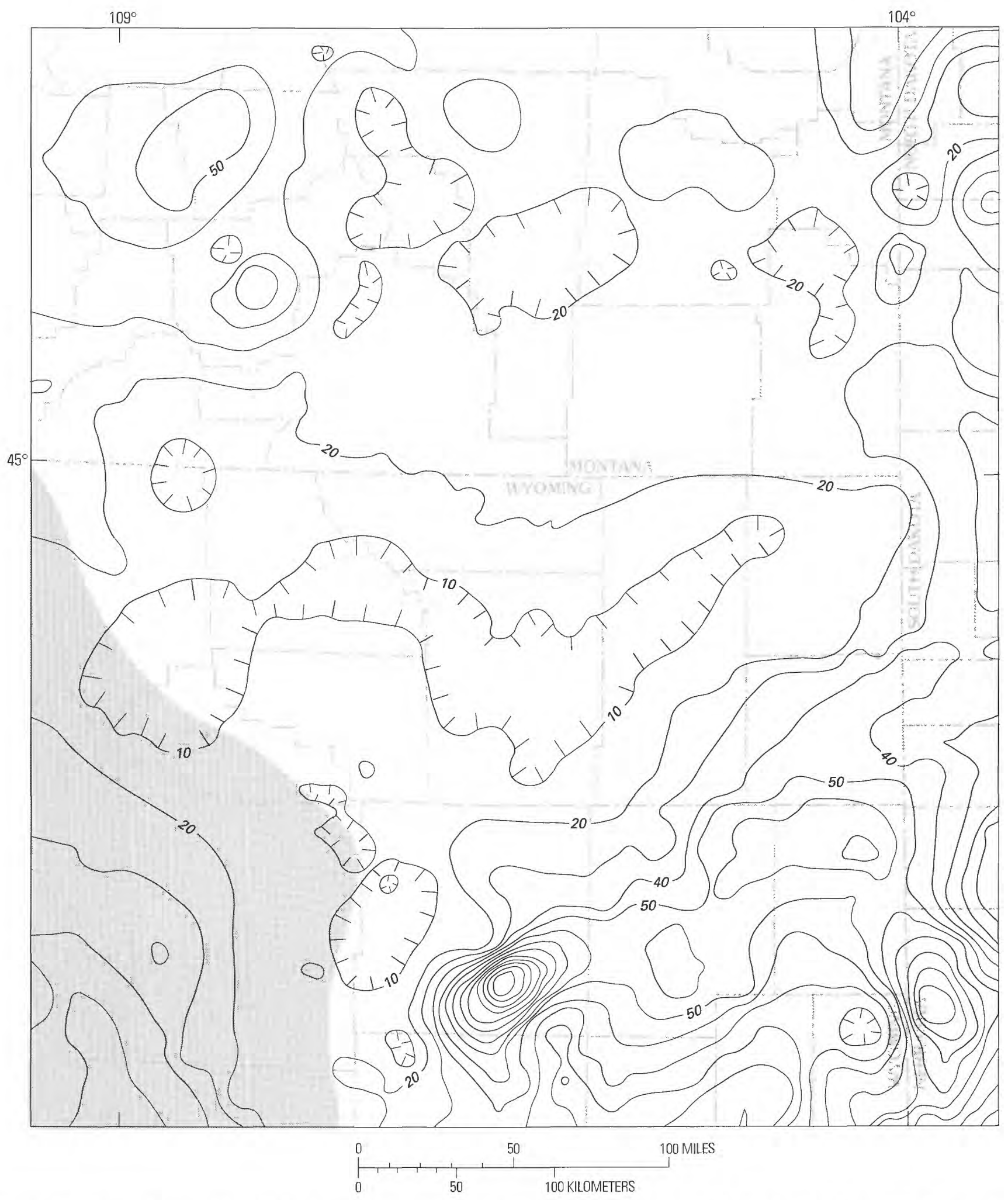

Figure 46. Isopach map of basal clastic unit of stratigraphic sequence four (primarily Kinderhookian and possibly Osagean). Contour interval $10 \mathrm{ft}(3.05 \mathrm{~m})$; zero-isopach line not mapped. Based on 303 wells; gridded on an approximately $7 \mathrm{mi}$ by $7 \mathrm{mi}$ grid $(12 \mathrm{~km}$ by $12 \mathrm{~km}$ ). Screened area in the southwestern corner of the map area is an area of very limited control. Includes surface data from Maughan (1963) and modified from Sando and Sandberg (1987). Map area shown in figure 3. 
In southern Wyoming, Sando and Sandberg (1987) divided the basal clastic sequence into two stratigraphic units: a lower conglomeratic interval, which in the northern Laramie Range Maughan (1963) established as conformable beIow the Madison Limestone, that they named the Fremont Canyon Sandstone, and an upper, finer grained clastic interval that they assigned to the Englewood Formation. The Fremont Canyon Sandstone at its type locality, however, was considered equivalent to the Cambrian Flathead Sandstone by previous workers (Lochman-Balk, 1972; Bell and Middleton, 1978). E.K. Maughan and I have traced the Fremont Canyon from its type locality southwest to the Rawlins Hills where it is the Flathead Sandstone. In the present report this basal sandstone at Fremont Canyon is included with the Cambrian rather than correlated to the basal Madison clastic unit. The name "Fremont Canyon Sandstone" is therefore not used in the present report.

Sando and Sandberg (1987) further divided the Englewood into an upper and a lower member separated by an unconformity. They assigned the upper member to the Kinderhookian and the lower member to the Upper Devonian. In the Rawlins Hills and Ferris Mountains, they assigned the whole interval a younger Kinderhookian age. In the Hartville uplift, they recognized only the Upper Devonian (Famennian) part of the Englewood Formation and their Fremont Canyon Sandstone. They based the age assignments on correlation with (1) the basal member of the Guernsey Formation in the Hartville uplift (Love, Denson, and Botinelli, 1949; Love, Henbest, and Denson, 1953), (2) the Englewood Formation of the Black Hills (Klapper and Furnish, 1963), and (3) the Cottonwood Canyon Member of the Madison Limestone in western Wyoming (Sandberg and Klapper, 1967).

In the Hartville uplift the basal Guernsey Formation was dated as Late Devonian and Early Mississippian based on undocumented brachiopod specimens (Love, Denson, and Botinelli, 1949; Love, Henbest, and Denson, 1953). The taxa reported form an antiquated faunal list and are an inadequate basis for an age assignment (N.M. Denson, U.S. Geological Survey, oral commun., 1988; T.W. Henry, U.S. Geological Survey, oral commun., 1989).

In the Black Hills, Klapper and Furnish (1963) dated the basal Englewood Formation as Late Devonian ("with reservation," p. 2076) and Early Mississippian based on correlations with the Guernsey Formation in the Hartville uplift and the presence of a conodont regarded as an index species of the Upper Devonian Clymenia-Stufe of Europe (Spathognathodus aculeatus $=S$. tridentatus Branson) (Klapper and Furnish, 1963, p. 2076, citing Sannemann, 1955; Bishoff and Ziegler, 1956; Flgel and Ziegler, 1957; Bender, 1958; Stoppel, 1958; Ziegler, 1959; Schriel and Stoppel, 1960; Freyer, 1961). Rhodes and others (1969, p. 237), however, subsequently reported this species from as high as the upper Kinderhookian $(c u I I \alpha)$ in Great Britain.
Sandberg and Klapper (1967) indirectly dated the lower part of the Madison Limestone as Late Devonian based on correlations with (1) the Englewood Formation of the Black Hills (Klapper and Furnish, 1963) and (2) the basal Guernsey Formation of the Hartville uplift (Love, Denson, and Botinelli, 1949; Love, Henbest, and Denson, 1953). Sandberg and Klapper (1967) then correlated the basal Madison with the basal section of the Hartville uplift based on the presence of "a conodont-bearing sandstone that is lithologically similar to both units [the Cottonwood Canyon Member of the Madison Limestone and the Englewood Formation] ${ }^{* * *}$ at the base of the Guernsey Formation of Devonian and Mississippian age [at Regan Draw in the Hartville uplift, southeast of the Powder River Basin in east-central Wyoming] described by Sandberg (1967)." Sandberg (1967, p. 65), however, did not describe the conodont fauna from the Guernsey Formation but noted only that a 3 -ft $(0.9 \mathrm{~m})$-thick sandstone $1 \mathrm{ft}(0.3$ $\mathrm{m})$ above the base of the section contains "leached molds of crinoids, conodonts, and minute fragments of fish plates***."

Sandberg and Klapper (1967) did not give a full faunal list from the lower tongue of the Cottonwood Canyon but reported a "representative" conodont collection considered "indigenous (unreworked) conodonts" (table 1, p. B51). The collection was from a lag deposit at the base of the member that contains $10-15$ percent $\mathrm{P}_{2} \mathrm{O}_{5}$, primarily as conodonts (Sandberg and Klapper, 1967, p. B29). The "representative fauna" includes only four species that were not also reported from either the underlying Devonian units or the overlying units dated as Kinderhookian by Sandberg and Klapper, and all of these have been reported either from rocks of uncertain Devonian or Mississippian age or from rocks of undisputed Mississippian age, or from both.

A Late Devonian ( $t o \mathrm{~V}$ ) age was assigned to the base of the Madison Limestone at Shoshone Canyon, Wyoming (Sandberg and Klapper, 1967, p. B50, B57), and at Dinwoody Canyon, Wyoming (Sandberg and Klapper, 1967, p. B50). The age at Shoshone Canyon was based on conodonts collected from a 2-in. $(51 \mathrm{~mm}$ )-thick lag sandstone at the base of Cottonwood Canyon Member. Sandberg (1963, p. B58) assigned the basal Madison to the very late Devonian age based on five conodonts collected from the basal $4 \mathrm{ft}(1.2 \mathrm{~m})$ of the Madison; he only gave the faunal list from the upper sample, however, "because its determination as Late Devonian precludes a Mississippian age for the four lower samples." The age assignment was based on conodonts originally named from the Maple Mill Shale in the Hannibal Group of southeast Iowa, which is of disrupted age. Klapper (1966, p. 29-30) gave the range of one of these (I. costatus) as the upper part of the Maple Mill Shale of Iowa, the Englewood Formation of South Dakota, and the dark shale unit of Sandberg (1963) in Wyoming and noted that this genus is closely allied with the one that ranges into the Early Mississippian (cuII $\alpha$ ). 
Klapper (1966, p. 8) assigned a Devonian (toV) age to the dark shale unit underlying the Madison at Bull Lake Creek in the Wind River Range, but an Early Carboniferous (cul) age has been assigned to the unit at Warm Spring Canyon, also in the Wind River Range (Klapper, 1966, p. 10), Darby Canyon, (Klapper, 1966, p. 8), Teton Canyon (Klapper, 1966, p. 10), and Horse Creek (Washakie Range), Wyoming (Klapper, 1966, p. 8; Sandberg and Klapper, 1967, p. B52), and Baker Mountain (Klapper, 1966, p. 8), Montana, and to the now abandoned Little Chief Canyon Member of the Lodgepole Limestone at People Creek (Little Rocky Mountains), Montana (Sandberg and Klapper, 1967, p. B53).

Sandberg and Klapper (1967, p. B53) reported that conodonts from their Warm Spring Canyon locality in Wind River Range (about $11 \mathrm{mi}, 18 \mathrm{~km}$, southwest of the Horse Creek locality) belong to a "poorly preserved fauna" recovered from a 2 -in. $(51 \mathrm{~mm})$-thick lag deposit at the base of the upper tongue of the Cottonwood Canyon Member, and Huddle (cited in Sandberg and Klapper as written commun., 1964) characterized most of the specimens as appearing "to be waterworn." Huddle tentatively considered the specimens to be lower, but not lowermost, Kinderhookian. At Windy Gap, Washakie Range, Wyoming, Sandberg and Klapper (1967, p. B51, sample WG-1) assigned an Early Carboniferous (lower $c u \mathrm{I}$ ) age to conodonts from a 1-in. ( $25 \mathrm{~mm}$ )-thick bed in the middle of the basal $1 \mathrm{ft}(0.3 \mathrm{~m})$ of the upper tongue of the Cottonwood Canyon Member $16 \mathrm{ft}(4.9 \mathrm{~m})$ above the base of the Madison Limestone. At Shell Canyon, on the west side of the Bighorn Mountains, Wyoming, Sandberg and Klapper (1967, p. B55, sample SH-3) reported a lower but not lowermost Kinderhookian (upper $c u l$ ) fauna from the upper tongue of Cottonwood Canyon Member. At Meridian Ridge, Montana, Sandberg and Klapper (1967, p. B55-56) assigned a fauna collected 5-9 in. (127-229 mm) above the base of the upper tongue of the Cottonwood Canyon Member to the upper Kinderhookian (cuII $\alpha)$ and noted that a second sample from 5.2-5.5 $\mathrm{ft}(1.6-1.7 \mathrm{~m})$ above the base of the tongue "does not contain as many conodont specimens but is similar in composition."

Seven species of conodonts were reported from rocks that were assigned to the basal Englewood Formation in the northern Laramie Range by Sando and Sandberg (1987, table 2), only two of which have been reported from rocks of unquestionable Kinderhookian age. Only Polygnathus experplexus Sandberg and Ziegler (1979), $P$. obliquicostatus (Ziegler, 1962), and Icriodus costatus (Thomas, 1949) have been reported from rocks that have been dated as Mississippian in age based on macrofauna and dated as Devonian in age based only on conodonts (Strainbrook, 1947, 1950; Thomas, 1949; Kelley, 1952; Workman and Gillette, 1956; Collinson, 1961; Atherton and others, 1975; Metzger, 1989). I. costatus and P. obliquicostata probably represent older Devonian forms that are reworked in both the Maple Mill Shale and the base of the Englewood Formation.

Craig and Connor (1979) did not consider the age of the basal clastic unit, but they dated the overlying carbonate rocks in southern Wyoming as Osagean. The work of Maughan (1963) and the evidence reviewed here support either a latest Kinderhookian or early Osagean age equally well. This interpretation agrees with Sando's (1976b) interpretation in which the Mississippian System onlapped the Transcontinental arch in southeastern Wyoming. Sando's figure $4 A$ shows the base of the Mississippian section in the northern Medicine Bow Mountains as Osagean. His figure $4 B$ shows the base of the section in the central Laramie Mountains as Kinderhookian, and his figure 6 suggests an early to latest Kinderhookian age in the same area. The conodont-based age assignments for the clastic sequence at the base of the Madison Limestone and the postulated unconformities within the clastic sequence are inconsistent with earlier work, including that of Sando (1976b), and should be regarded as questionable.

I consider the clastic sequence in the southern Powder River Basin area to be an early expression of the ancestral Front Range and Pathfinder uplifts.

\section{Bakken and Exshaw Formations}

The Bakken and Exshaw Formations (fig. 35) are a marine sequence of dark-gray carbonaceous shale and mudstone and yellowish-brown silty dolomite that includes black phosphate pellets, carbonaceous debris, glauconite, calcite and quartz nodules, worm impressions and burrows, Taonurus, swash marks, fish plates and teeth, large conodonts, echinoids, clay intraclasts, and hematite. The basal part of the sequence is locally sandstone or siltstone containing reworked pebbles. Dolomite lenses within the interval are yellowish brown, silty, and calcareous and contain abundant crinoid remains. The importance of phosphate within the black shale and the association of the shale with shallow-water marine units suggest that the shale formed during upwelling on a shallow shelf (see, for example, Heckel, 1972).

In central Montana and western North Dakota, the Bakken Formation (Nordquist, 1953) forms the base of stratigraphic sequence four (fig. 35). The name Bakken was originally applied to rocks previously assigned to the Paine Member of the Lodgepole Limestone (Sloss and Hamblin, 1942) in central Montana and to a black shale at the base of the Madison Group (Cooper and Sloss, 1943). The Bakken is made up of lower and upper dark shale units separated by a medial siltstone. In the southern Canadian Cordillera, only the lower black shale unit is distinguishable because the upper unit grades laterally into the basal shaly member of the Banff Formation, the stratigraphic equivalent to the Lodgepole Limestone. Where the upper member of the Bakken cannot be distinguished, the 
lower two units are known as the Exshaw Formation (for example, in the mountains of northeastern British Columbia and the Alberta Rocky Mountains of Canada; Macauley and others, 1966, fig. 7-3). Macauley and others (1966) assigned a Kinderhookian age to the Bakken and Exshaw interval in Canada.

In the Williston Basin, the Bakken is disconformable on the Upper Devonian Trident Member of the Three Forks Formation (fig. 35) and is made up of lower and upper radioactive black shale members separated by a medial siltstone unit. The Bakken reaches is as thick as about $140 \mathrm{ft}(43 \mathrm{~m})$ in the central Williston Basin of northwestern North Dakota (Sandberg and Mapel, 1967). Sandberg and Mapel (1967) believed that the upper black shale was removed by Early Mississippian erosion in northwestern Montana, but Macauly and others (1966) interpreted a similar stratigraphic relationship in adjacent parts of Alberta, Canada, to represent a facies change from black shale at the top of the unit to a lithology indistinguishable from the overlying Banff Formation. Cooper and Sloss (1943) included the clastic sequence at the base of the Madison Limestone in western North Dakota and in southwestern Montana as part of the Madison Group and dated the clastic sequence as Kinderhookian.

In western Alberta, Macqueen and Sandberg (1970) considered the Exshaw Formation to be Late Devonian (Famennian) and Early Mississippian in age; however, they based the Devonian age on "representative" conodont fauna collected from a 1-2-in. (25-51 mm)-thick basal lag deposit that probably accumulated as an insoluble residue prior to the deposition of the Exshaw. The conodont ages, therefore, are undoubtedly older than the actual age of the Exshaw. Further evidence given for the Devonian age was correlation with the Sappington Member of the Three Forks Formation (Klapper, 1966; Sandberg and Klapper, 1967) and with the Leatham Formation (Sandberg and Gutschick, 1969). The dates for all these units, however, are based on conodonts from basal lag deposits and are considered suspect. Macqueen and Sandberg (1970, p. 53) unequivocally accepted an Early Mississippian ammonite age for the upper $2.5 \mathrm{ft}(0.76 \mathrm{~m})$ of the basal black shale unit of the Exshaw Formation at its type locality near Exshaw, Alberta.

Thrasher (1987) considered the base of the Bakken Formation in western North Dakota to be the same age as the base of the Sappington Member of the Three Forks Formation in southeastern Montana (Sandberg and Klapper, 1967; Gutschick and Rodriguez, 1977, 1979) and accepted a probable Late Devonian age. In the present report, the Bakken is assumed to be Early Mississippian (Kinderhookian) in age and a time-transgressive facies equivalent to the Cottonwood Canyon Member of the Lodgepole Limestone (E.K. Maughan, written commun., 1989) and the basal clastic sequence of the southern Powder River Basin area.
Paine Member of the Madison and Lodgepole Limestones

In central Montana, Weed $(1899 \mathrm{a}, \mathrm{b})$ named the basal unit of the Madison Limestone the Paine Member. In western Montana and adjacent areas of Utah, and Idaho, the Paine Member is a dark-gray to black argillaceous limestone that is present locally and is gradational into the base of the Lodgepole Limestone (Cooper and Sloss, 1943; Sandberg, 1963; Benson, 1966). Sloss and Hamblin (1942) included the Paine as a member of the Lodgepole Limestone and documented its presence throughout southwestern Montana. The Paine is as thick as $331 \mathrm{ft}(101 \mathrm{~m})$ in west-central Montana, thins progressively southward, and is absent in the Pryor and Bighorn Mountains. In the Bridger Mountains, the Paine overlies the Sappington Member of the Three Forks Formation (Laudon and Severson, 1953). In central Idaho, a partial equivalent of the Sappington may be present as either the upper part of the Milligen Formation or the lower part of the Little Copper Formation (Paull and Gruber, 1977), which underlies the Lodgepole Limestone equivalent and may be similar in age and origin to the Paine in western Montana (Benson, 1966). In southeastern Idaho and northeastern Utah, south of the Snake River downwarp, rocks of the same age and similar lithology are referred to as the Leatham Formation (Holland, 1952).

\section{Lodgepole Limestone}

The Lodgepole Limestone (fig. 35) is the basal unit of the Madison Group and represents the first carbonate deposits of the Early Mississippian transgression (fig. 38). The Lodgepole consists of gray to dark-gray, argillaceous to shaly or silty, in places cherty, thin- to medium-bedded limestone (Peterson, 1984). In most places, the relatively clean carbonate rocks of the Lodgepole Limestone conformably overlie the Bakken Formation (Benson, 1966; Peterson, 1984) or its siliciclastic and carbonate facies equivalents, the Cottonwood Canyon Member of the Lodgepole, the Sappington Member of the Three Forks, and the Englewood Formation. In north-central Montana, crinoid mounds overlie the Bakken at several locations (Peterson, 1984).

Lower Mississippian rocks (Paine Limestone) in the Tendoy Mountains rest on orange and red siltstone and mudstone, crinoidal wackestone, evaporite solution breccia, and silty dolomite containing Late Devonian brachiopods of the Three Forks Formation.

\section{Mission Canyon Limestone}

The middle unit of the Madison Group is the Mission Canyon Limestone (fig. 35) and consists of generally thick- to massive-bedded fossiliferous to oolitic carbonate 
rocks (Peterson, 1984). Interpreted barrier environments within the Mission Canyon range from beaches to medium- and low-energy tidal flats, depending on the amount of wave and tidal current energy along the strandline. Beach strata include buff, well-sorted and rounded, pisolitic-oolitic-intraclastic lime grainstone, whereas tidalflat units are buff to brown, poorly sorted, lime packstone to wackestone having fenestrae and desiccation features. Each type of unit attains maximum thicknesses of about $20 \mathrm{ft}(6.1 \mathrm{~m})$. The oolite and pisolite in these deposits display structures indicating a hypersaline, low-energy depositional environment (Loreau and Purser, 1973); however, they may have formed by weathering and the formation of paleosol (Gerhard and others, 1978). The pisolitic units have previously been referred to in the literature as algal reefs (Hansen, 1966).

Inden and Moore (1983) informally divided the Mississippian Mission Canyon Limestone in the Little Knife field of the Williston Basin into several facies. At the base, open-marine carbonate rocks grade upward into restricted lagoon deposits overlain by barrier and near-barrier carbonate rocks. These beds are, in turn, overlain by lagoonal anhydrite and salt. Each barrier bed grades laterally into correlative restricted-lagoonal and open-marine beds basinward and into lagoonal-evaporite beds landward.

\section{Charles Formation}

The uppermost unit of the Madison Group is the Charles Formation (fig. 35) consisting of anhydrite and halite interbedded with carbonate and shale (Peterson, 1984). The Charles Formation is not present within the Powder River Basin but is present north of the basin (pls. 1, 2).

\section{Madison Limestone (Group) Marker System}

The lithologic units of the Madison represent intertonguing lithofacies composed of numerous depositional cycles divided by a series of 13 marker-defined units. The marker units consist of thin but widespread shaly carbonate or dark-shale intervals. Peterson (1984) subdivided the Mississippian section chronostratigraphically, using a marker horizon system. Marker M1 is roughly at or above the Devonian-Mississippian boundary; interval M1 to M3 is roughly Kinderhookian; interval M3 to M7 is lower Osagean; interval M7 to M8.5 is middle Osagean; interval M8.5 to M12 is upper Osagean; and interval M12-Mc is roughly Meramecian. The marker units are best expressed in the central Williston Basin but also extend into the surrounding areas (Peterson, 1984). Using the marker system defined by Peterson (fig. 35), I mapped six horizons within the Madison. Marker Ml is the first marker horizon and is at the base of the
Madison, generally above an interval correlated with the Kinderhookian Bakken-Cottonwood Canyon-Englewood interval; marker M3 is near the Kinderhookian-Osagean boundary; markers M7 and M8.5 are within the Osagean; marker M12 is near the Osagean-Meramecian boundary; and marker M12-Mc is the top of the Madison.

Marker M8.5 is at the top of a thick anhydrite interval, equivalent to the top of the lower solution zone in northcentral Wyoming (Sando, 1974; Peterson, 1984). Marker M7 is roughly at the stratigraphic position of the lower, thinner, less widespread anhydrite interval in the Central Montana trough. Marker M10, which has not been mapped, is equivalent to the "Richey shale marker" of subsurface usage in the Williston Basin. Marker M12, correlated to outcrop data in the Bighorn Mountains, is roughly equivalent to the upper solution zone of Sando (1974) (Peterson, 1984).

The interval between markers M1 and M3 (roughly Kinderhookian) (figs. 38, 47, 48) is generally gradational throughout the area from the underlying Bakken-Englewood interval (Peterson, 1984) (fig. 35). The basal Lodgepole Limestone contains Waulsortian crinoidal carbonate mounds in its lower half, especially on the western, southwestern and eastern flanks of the Williston Basin (Cotter, 1965; Smith, 1972; Stone, 1972; Bijorlie and Anderson, 1978). The main trend of Waulsortian mounds follows the general trend of the Central Montana uplift (fig. 1), which probably continued as a paleostructure influencing deposition well into earliest Mississippian time.

The M1-M5 interval is generally equivalent to the Lodgepole Limestone (fig. 35). Read (1985, p. 6) cited this interval as an example of ramps associated with barrier ooid pellet shoal complexes (see Edie, 1958; Wilson, 1975). In north-central and northwestern Wyoming and south-central Montana, the lower part of the Lodgepole is completely dolomitized. In central, south-central, and southeastern Montana, northeastern Wyoming, and northwestern South Dakota, the upper half of the Lodgepole is oolitic carbonate banks. Toward the center of the Williston Basin, oolitic and crinoidal mounds grade into finegrained argillaceous and pyritic limestone. Locally, especially on the southern and western flanks of the basin, carbonate mounds are as thick as $400 \mathrm{ft}(122 \mathrm{~m})$. In most places argillaceous carbonate rocks or gray calcareous shale of the M3 marker overlie the upper beds of the previous cycle.

The M3-M7 interval (lower Osagean) (figs. 39, 49, 50) is generally $200-300 \mathrm{ft}(61-91 \mathrm{~m})$ thick around the flanks of the Williston Basin and more than $600 \mathrm{ft}(183 \mathrm{~m})$ thick in the basin center and in the Central Montana trough. The lower two-thirds of the interval represents the upper half of the shaly Lodgepole Limestone in the central Williston Basin and in the Central Montana trough. Oolitic carbonate rocks dominate the flanks of the Williston Basin and in the upper part prograde toward the basin interior, where some 


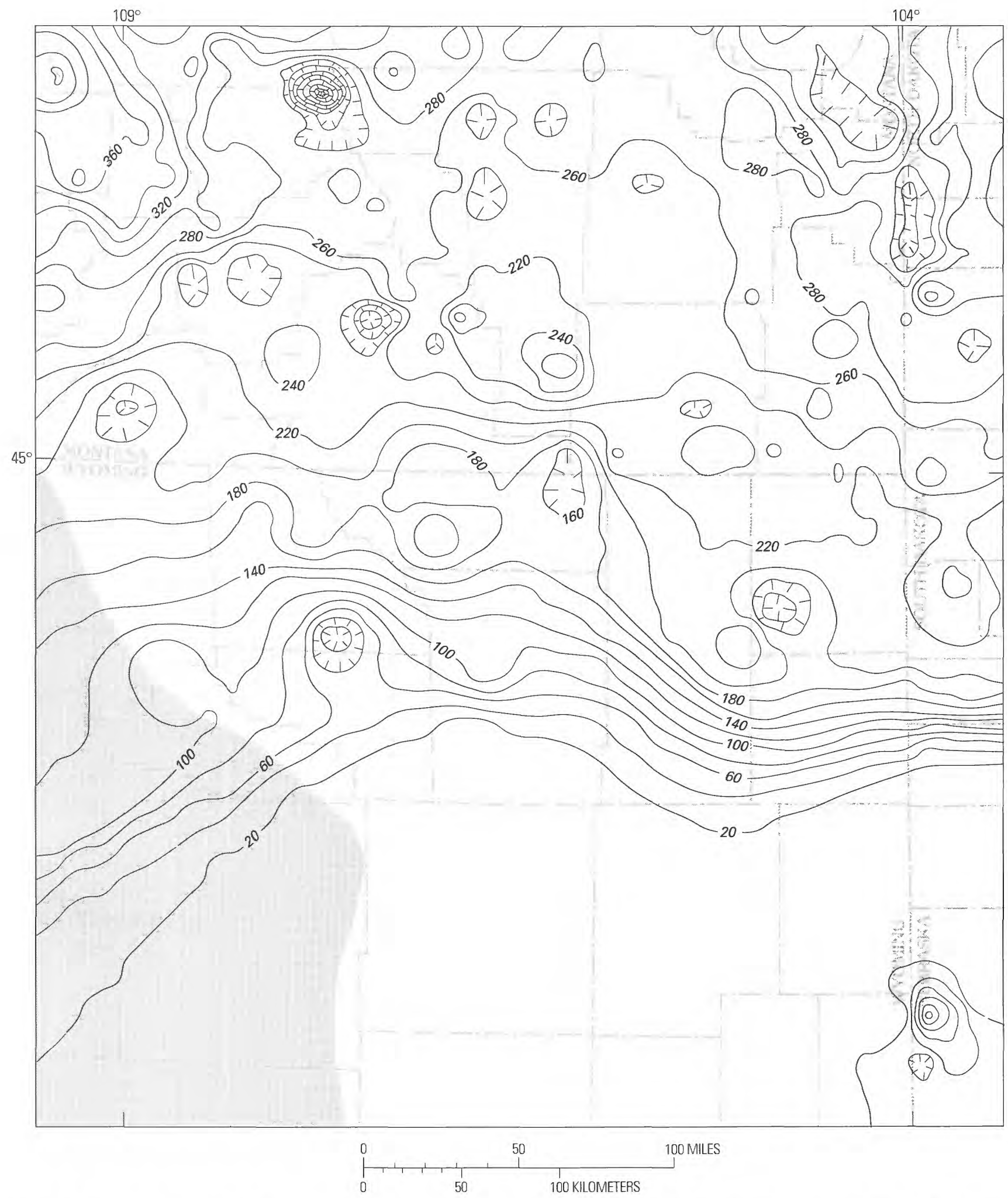

Figure 47. Isopach map of M1-M3 interval of stratigraphic sequence four (Lower Mississippian, approximately Kinderhookian). Contour interval $20 \mathrm{ft}(6.1 \mathrm{~m})$; zero-isopach line not mapped. Based on 314 wells; gridded on an approximately 7 mi by 7 mi grid (12 km by $12 \mathrm{~km})$. Screened area in southwestern part of map area is an area of very limited control. Data modified from Downey (1982). Map area shown in figure 3. 


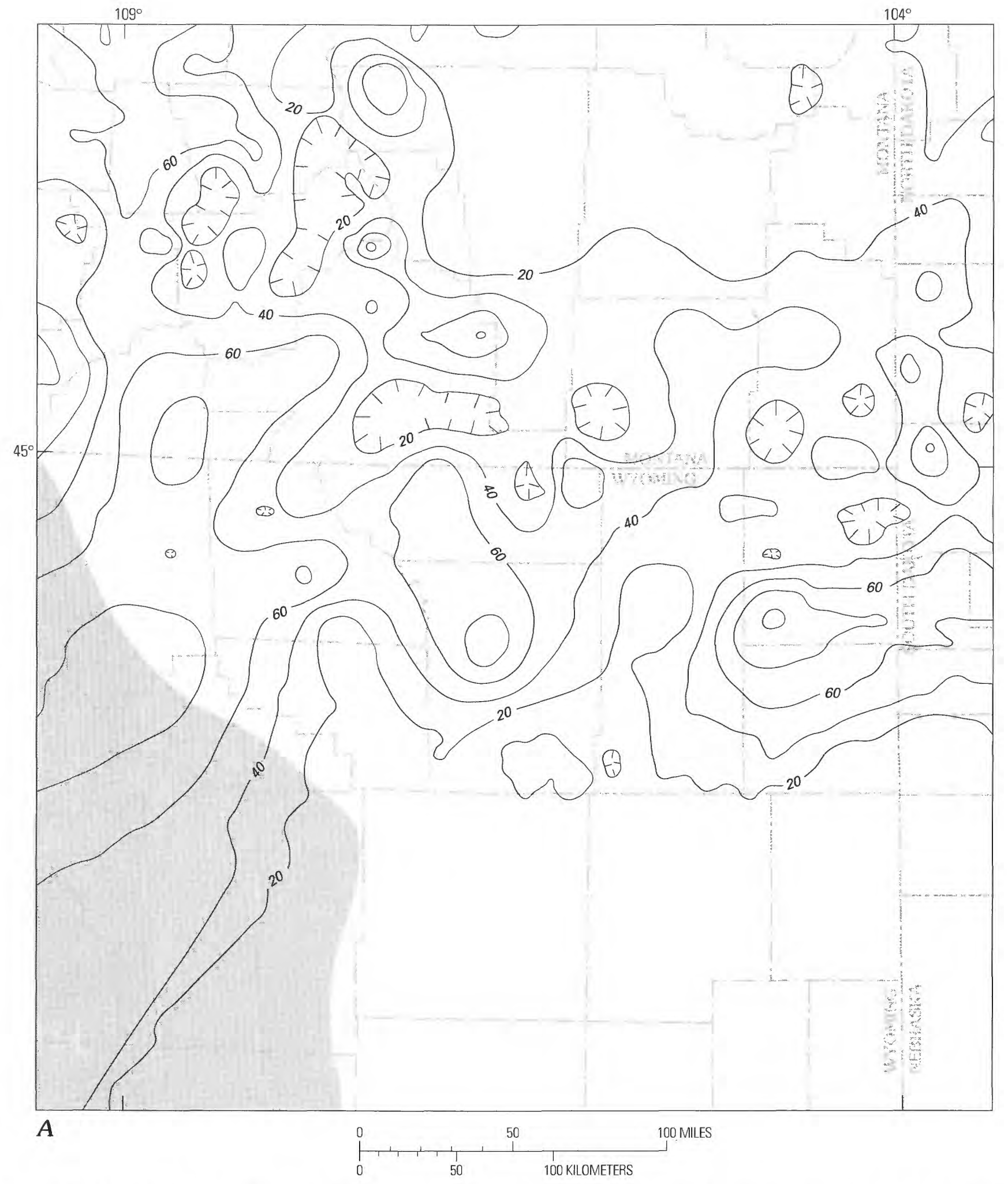

Figure 48. Lithology of $M 1-M 3$ interval of stratigraphic sequence four (Lower Mississippian, approximately Kinderhookian). Based on 281 wells; gridded on an approximately $7 \mathrm{mi}$ by $7 \mathrm{mi}$ grid (12 km by $12 \mathrm{~km}$ ). Zero-percent line not mapped. Map area shown in figure 3. Screened area in southwestern part of map area is an area of very limited control. Data from Downey (1982). A, Dolomite (contour interval 20 percent). 


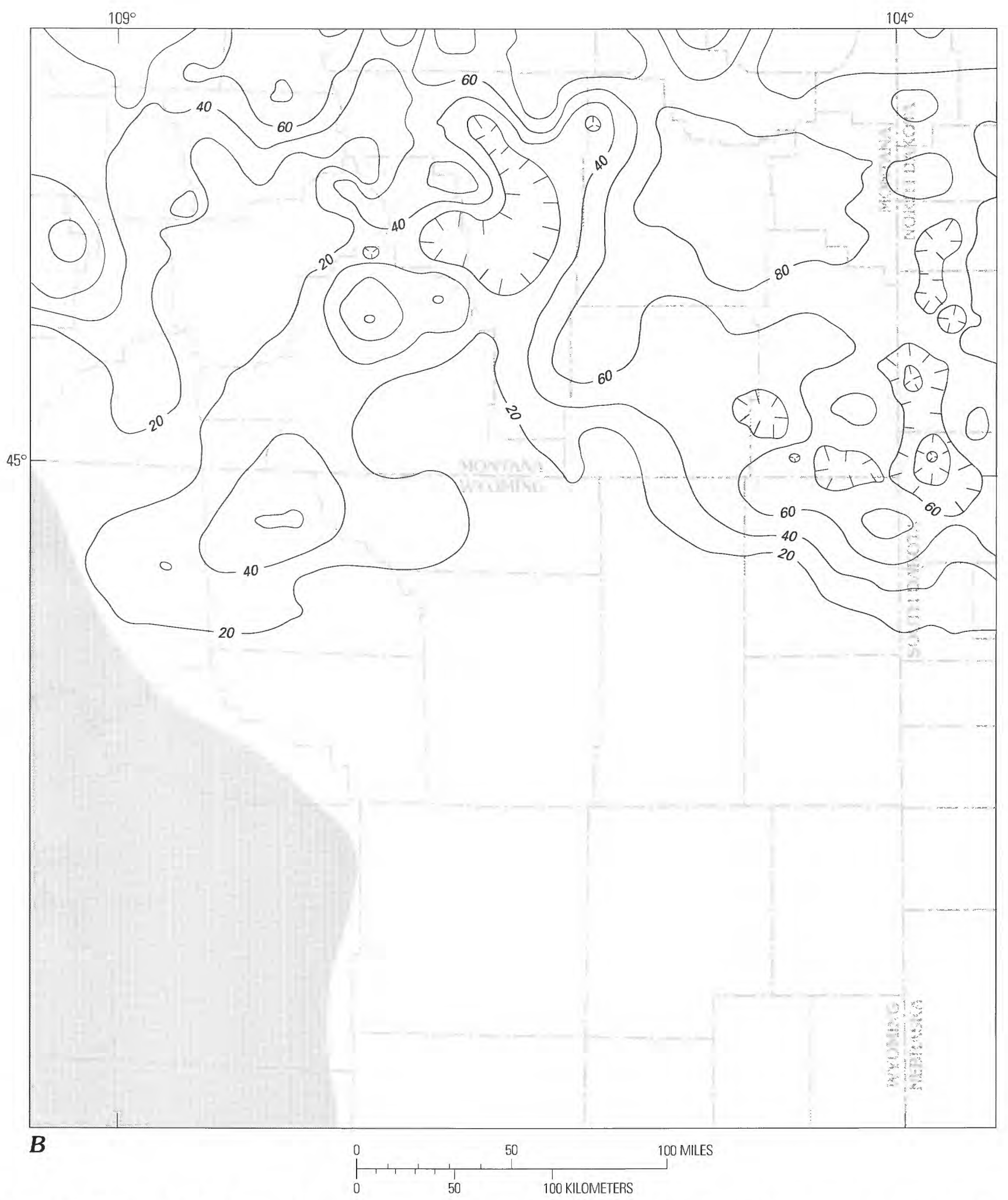

Figure 48 (continued). Lithology of $M 1-M 3$ interval of stratigraphic sequence four (Lower Mississippian, approximately Kinderhookian). B, Limestone (contour interval 20 percent). 


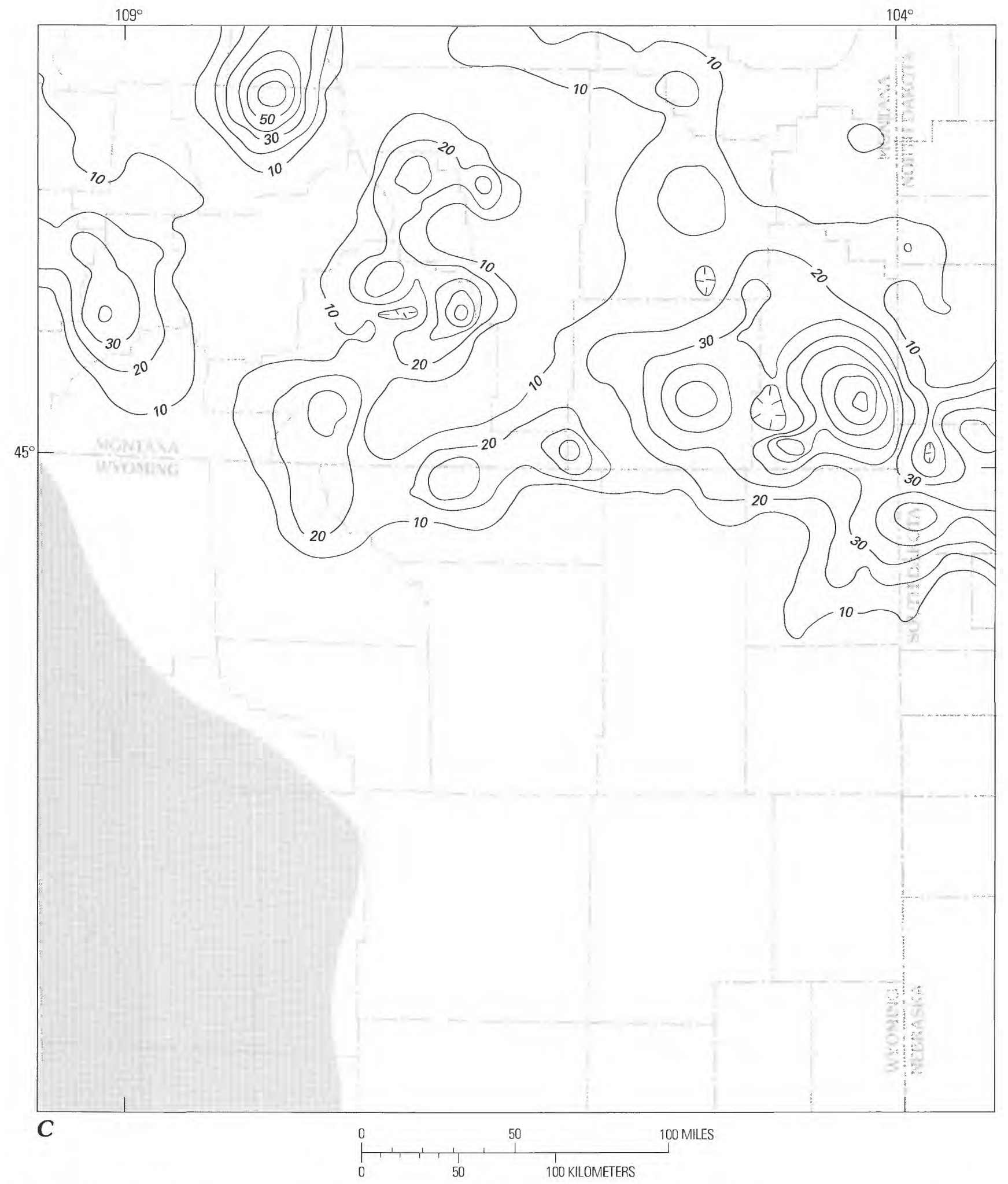

Figure 48 (continued). Lithology of $M 1-M 3$ interval of stratigraphic sequence four (Lower Mississippian, approximately Kinderhookian). C, Oolitic carbonate (contour interval 10 percent). 


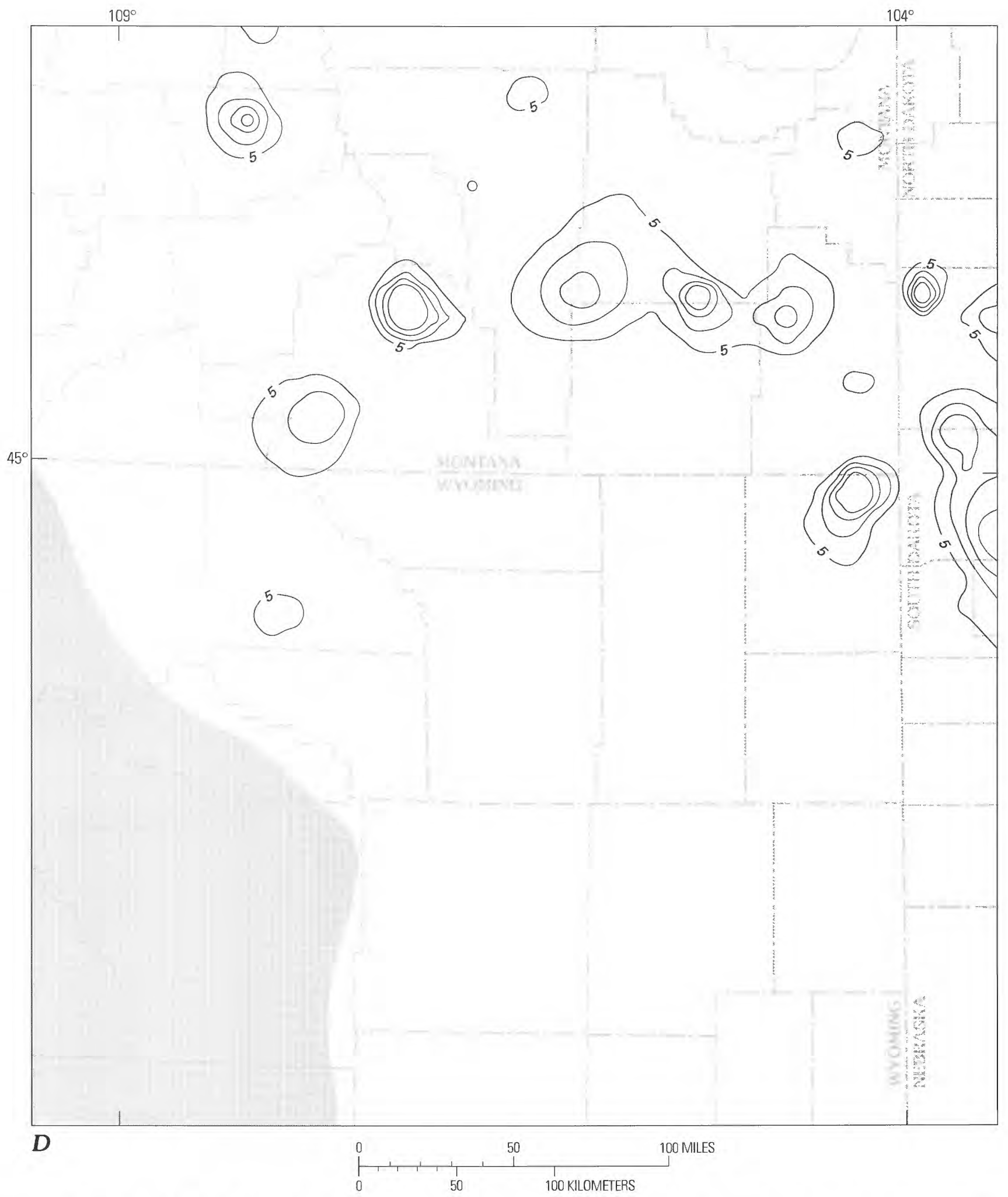

Figure 48 (continued). Lithology of M1-M3 interval of stratigraphic sequence four (Lower Mississippian, approximately Kinderhookian). D, Algal carbonate (contour interval 5 percent). 


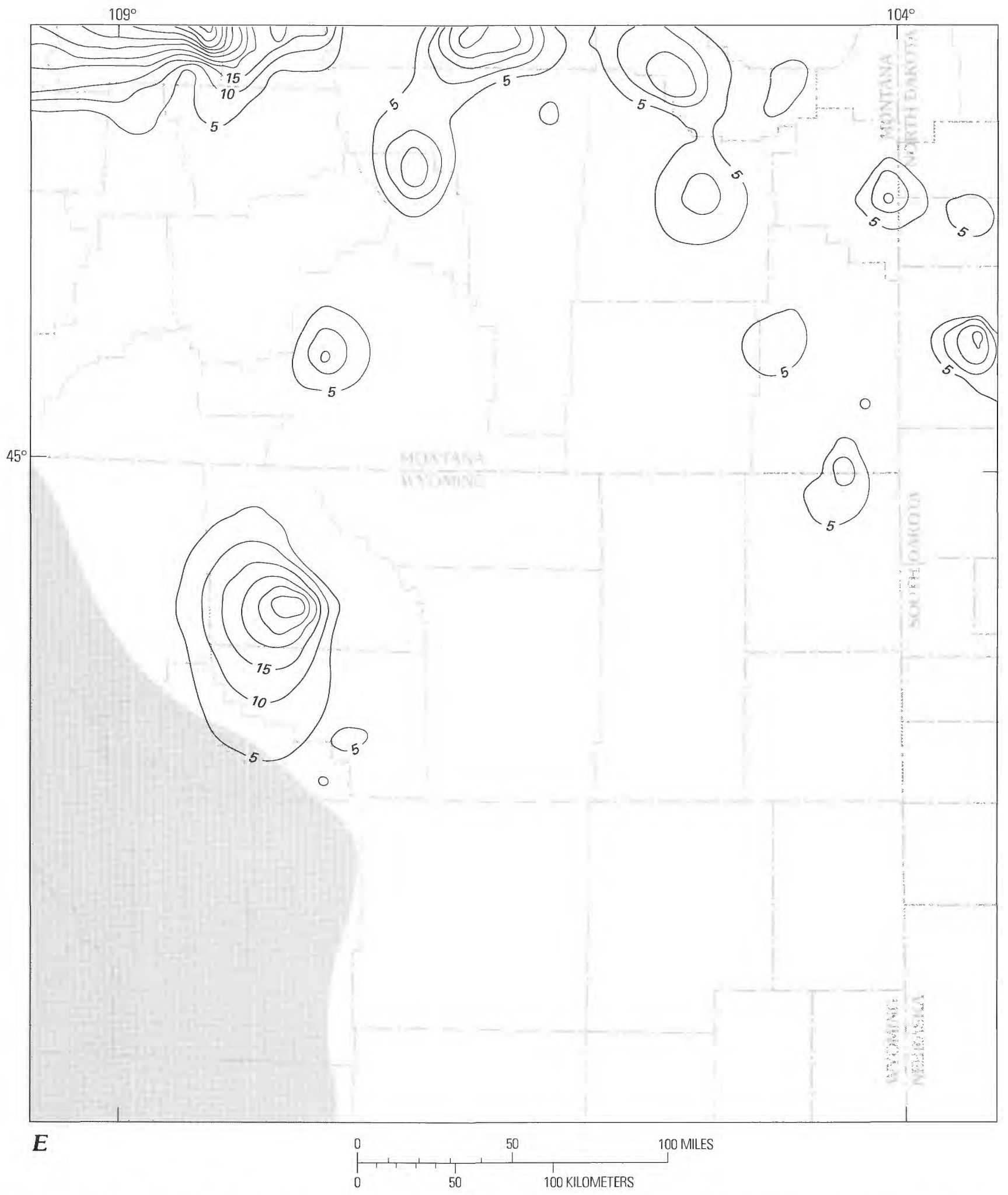

Figure 48 (continued). Lithology of $\mathrm{M} 1-\mathrm{M} 3$ interval of stratigraphic sequence four (Lower Mississippian, approximately Kinderhookian). E, Crinoidal carbonate (contour interval 5 percent). 


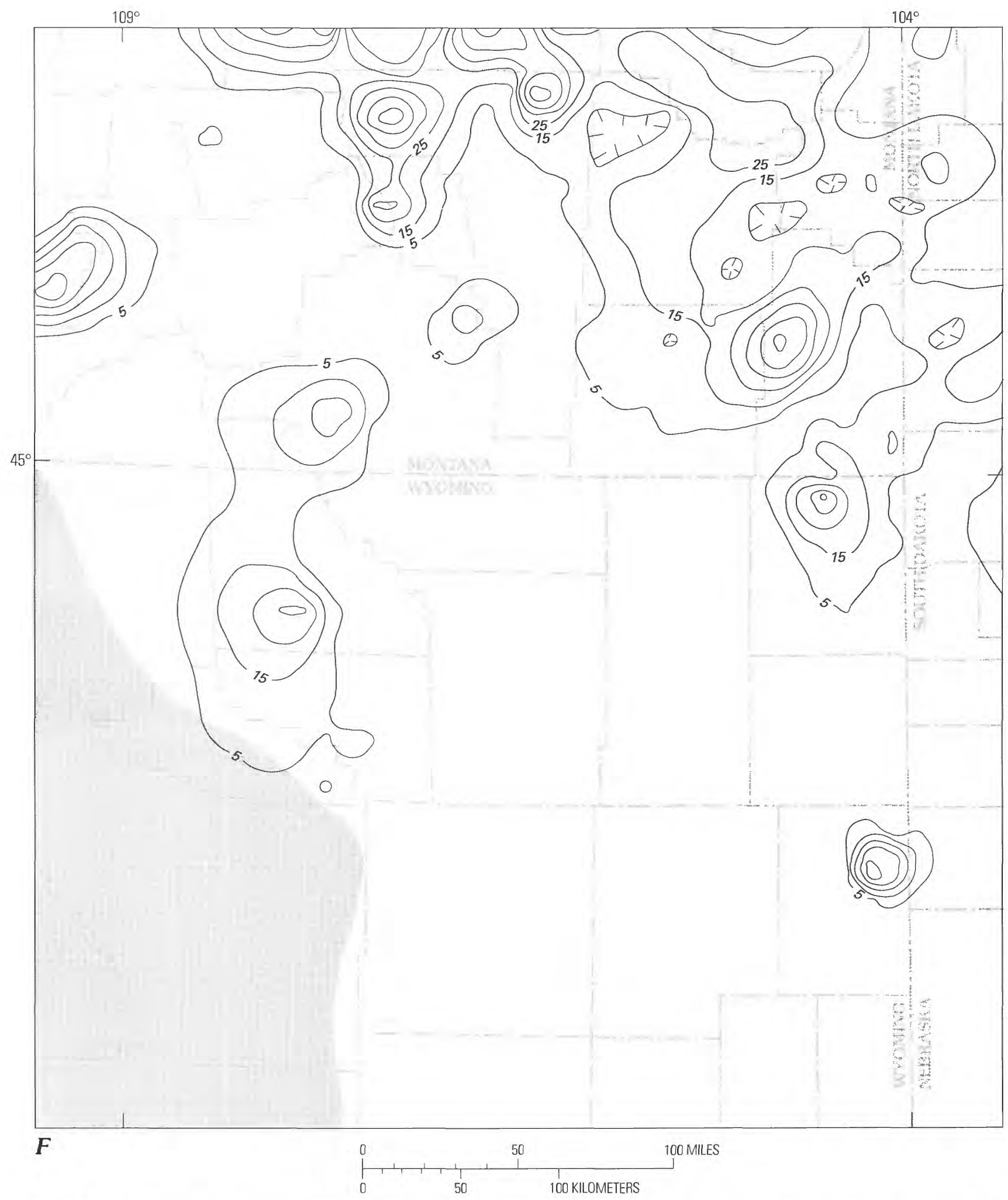

Figure 48 (continued). Lithology of M1-M3 interval of stratigraphic sequence four (Lower Mississippian, approximately Kinderhookian). F, Bioclastic carbonate (contour interval 10 percent). 


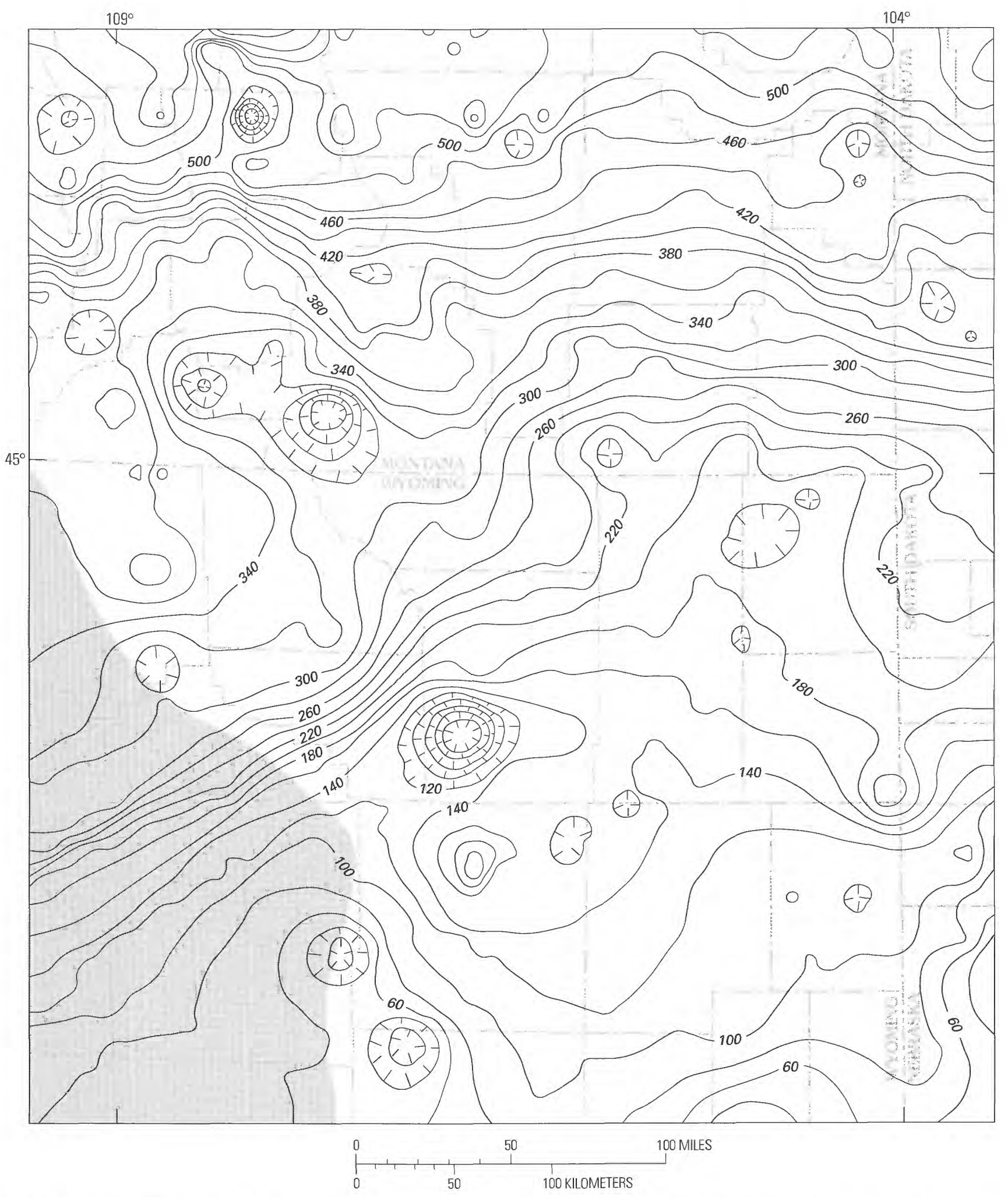

Figure 49. Isopach map of M3-M7 interval of stratigraphic sequence four (Lower Mississippian, approximately lower Osagean). Contour interval $20 \mathrm{ft}(6.1 \mathrm{~m})$. Based on 323 wells; gridded on an approximately $7 \mathrm{mi}$ by 7 mi grid (12 km by $12 \mathrm{~km})$. Screened area in southwestern part of map area is an area of very limited control. Data modified from Downey (1982). Map area shown in figure 3 . 


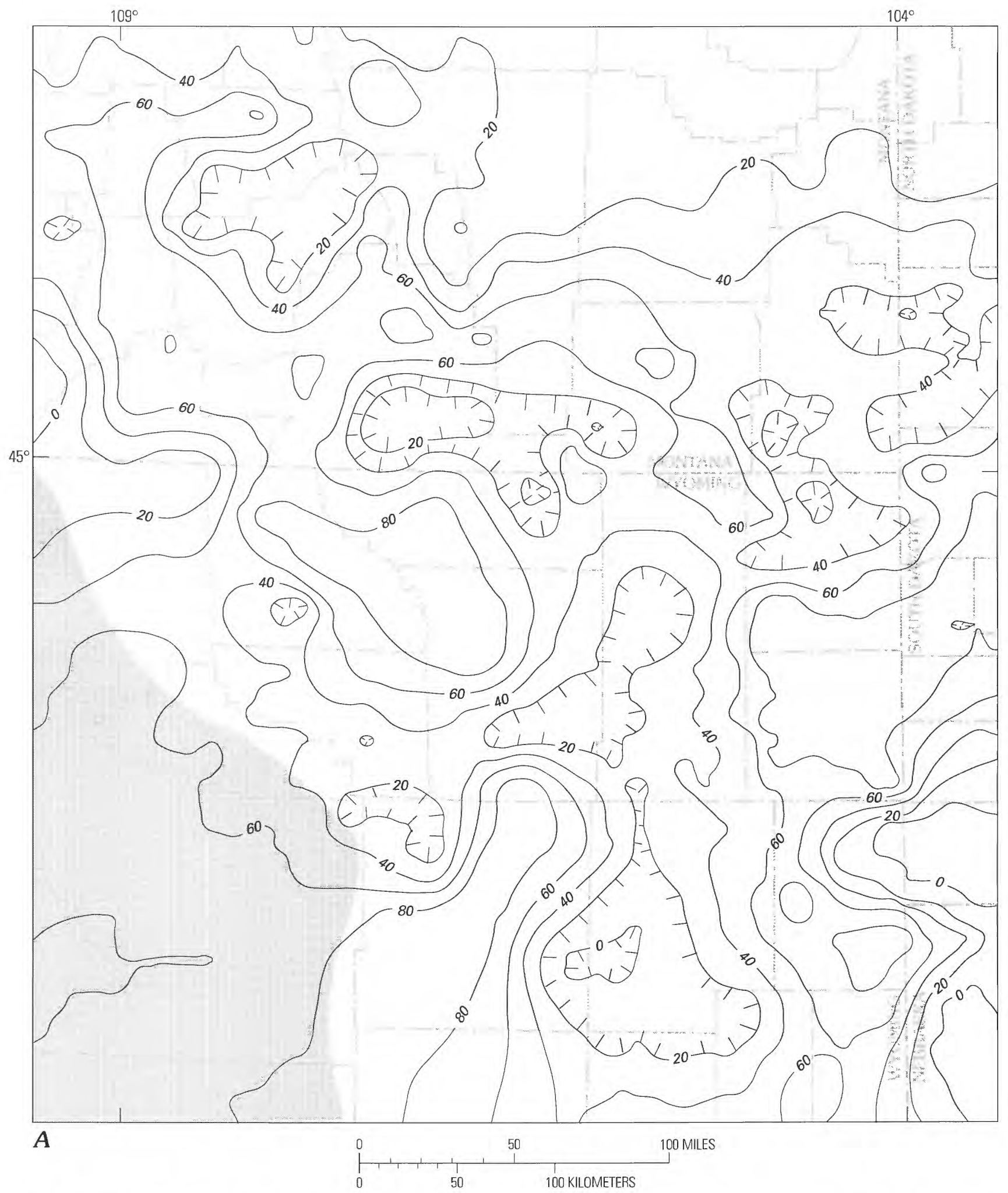

Figure 50. Lithology of $M 3-M 7$ interval of stratigraphic sequence four (Lower Mississippian, approximately lower Osagean). Based on 281 wells; gridded on an approximately 7 mi by 7 mi grid $(12 \mathrm{~km}$ by $12 \mathrm{~km})$. Screened area in southwestern part of map area is an area of very limited control. Data from Downey (1982). Map area shown in figure 3. A, Dolomite (contour interval 20 percent). 


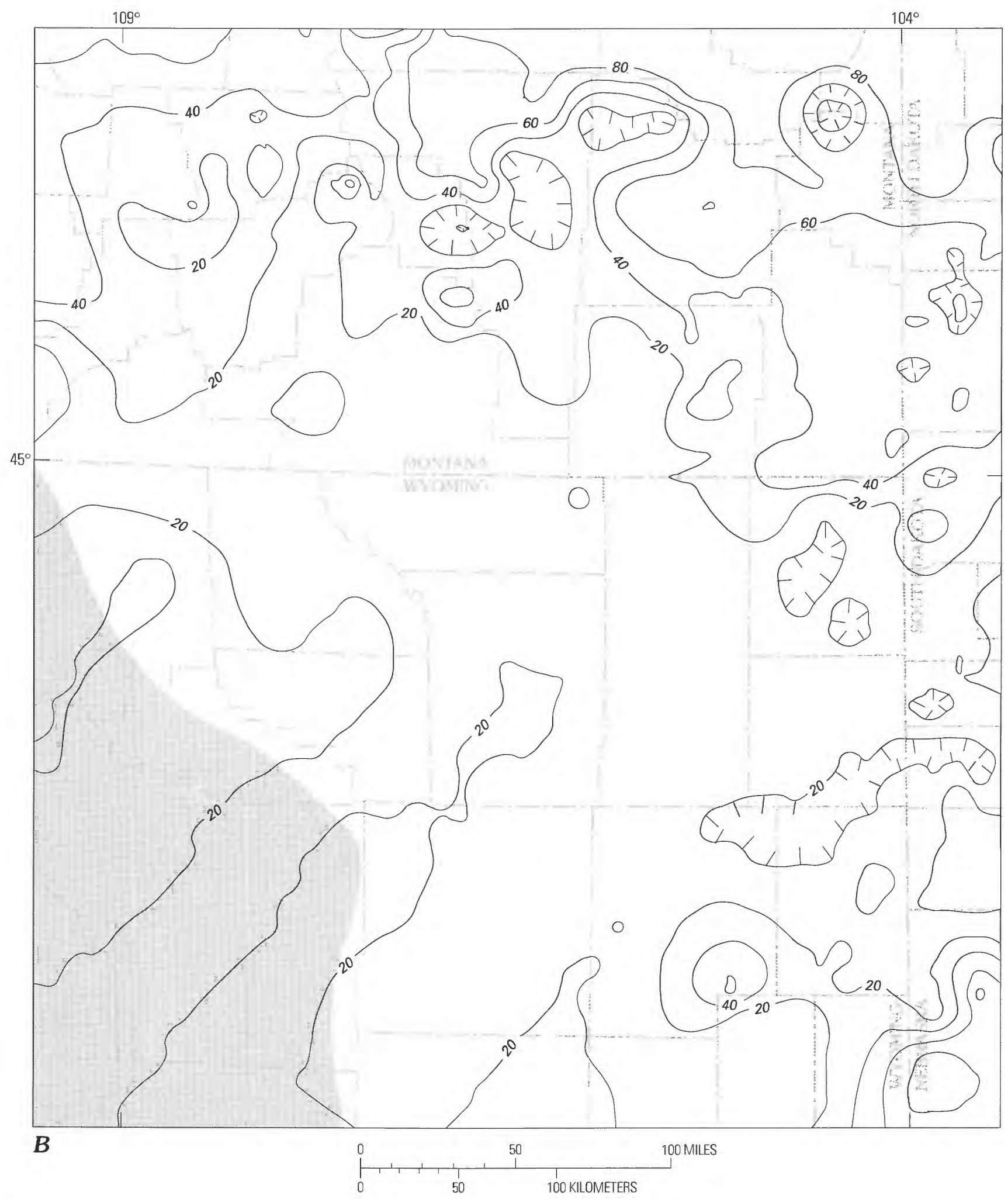

Figure 50 (continued). Lithology of $M 3-M 7$ interval of stratigraphic sequence four (Lower Mississippian, approximately lower Osagean). B, Limestone (contour interval 20 percent). 


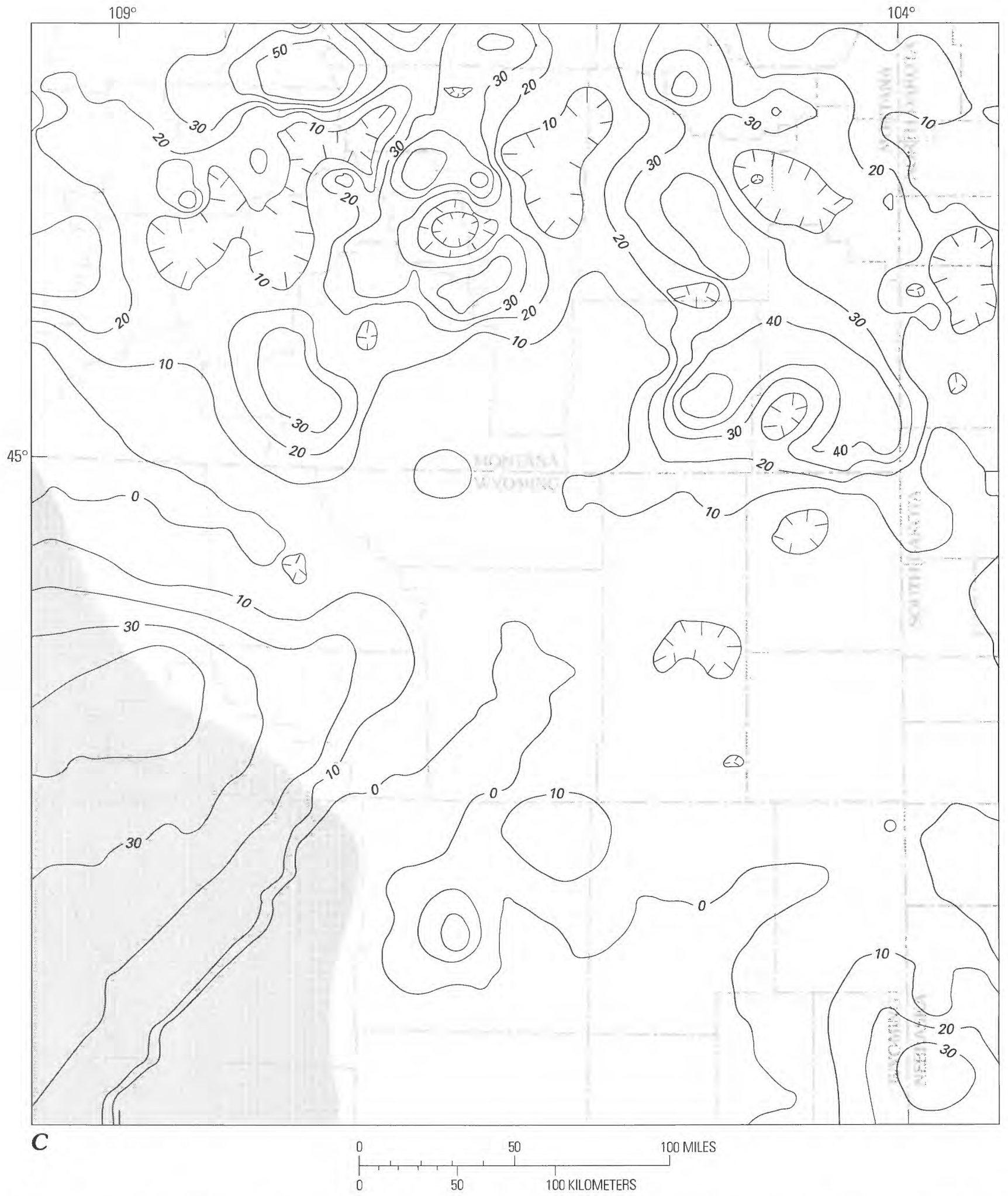

Figure 50 (continued). Lithology of M3-M7 interval of stratigraphic sequence four (Lower Mississippian, approximately lower Osagean). C, Oolitic carbonate (contour interval 10 percent). 


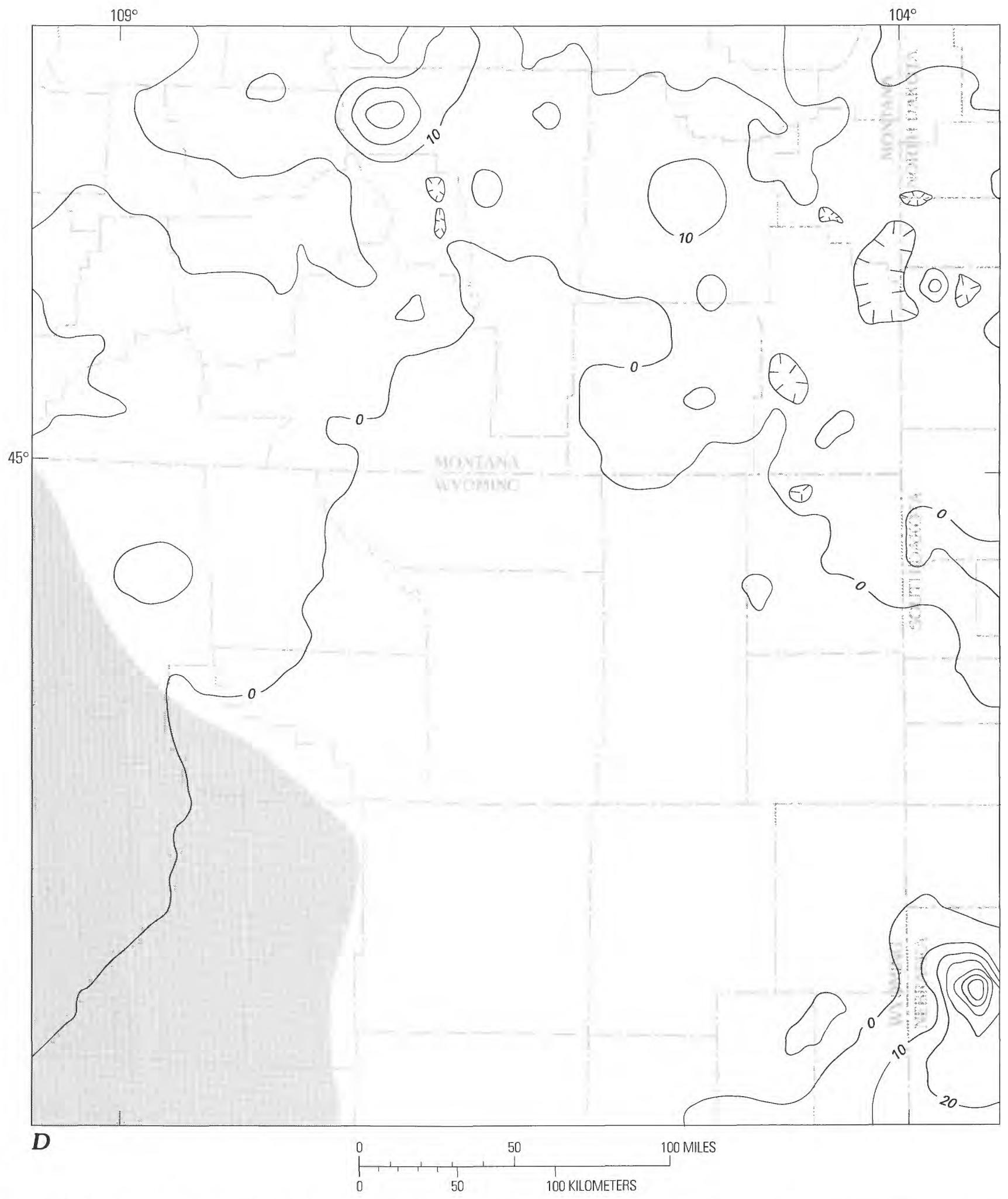

Figure 50 (continued). Lithology of $M 3-M 7$ interval of stratigraphic sequence four (Lower Mississippian, approximately lower Osagean). $D$, Algal carbonate (contour interval 10 percent). 


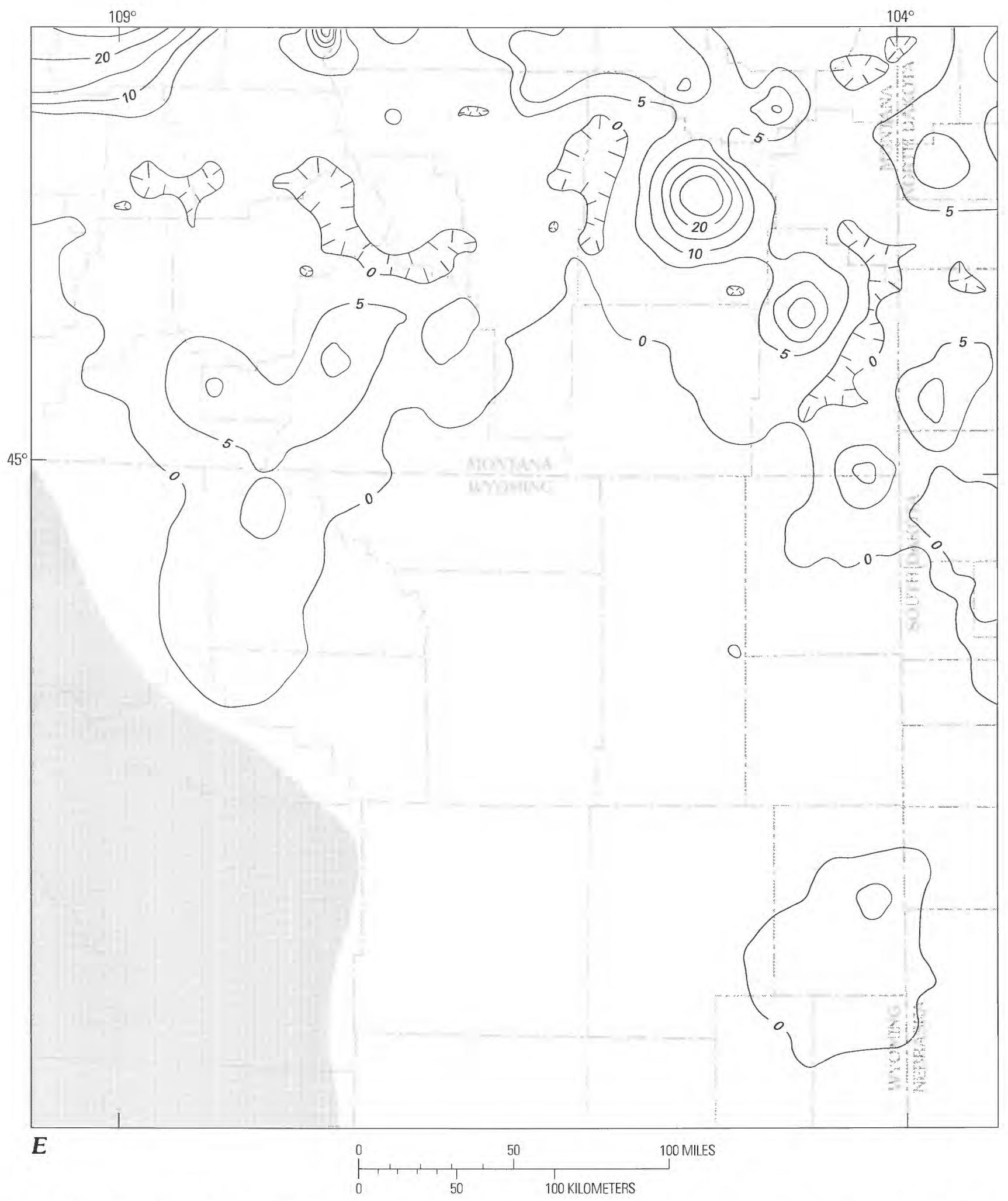

Figure 50 (continued). Lithology of M3-M7 interval of stratigraphic sequence four (Lower Mississippian, approximately lower Osagean). E, Crinoidal carbonate (contour interval 5 percent). 


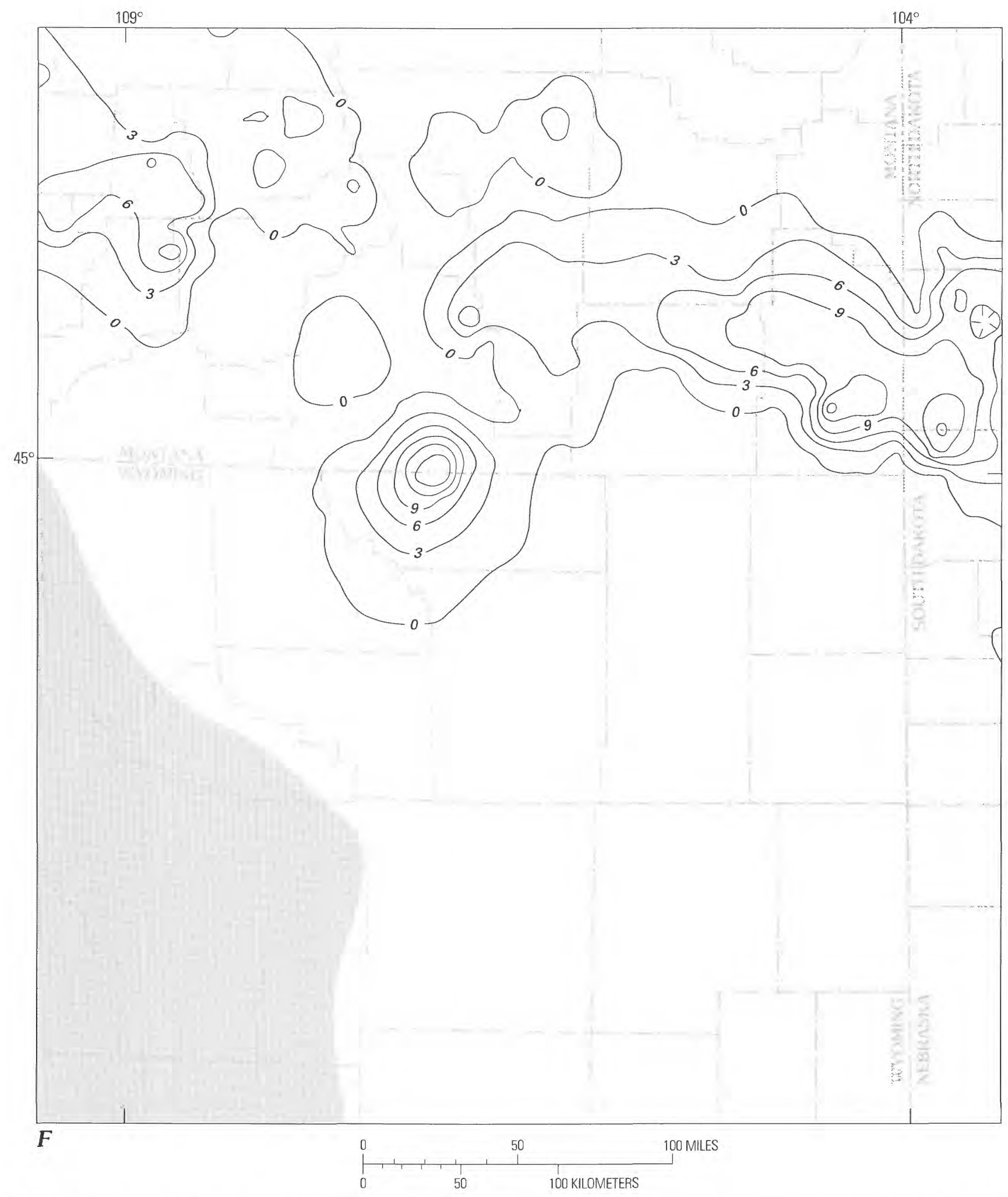

Figure 50 (continued). Lithology of $M 3-M 7$ interval of stratigraphic sequence four (Lower Mississippian, approximately lower Osagean). F, Evaporite (contour interval 3 percent). 


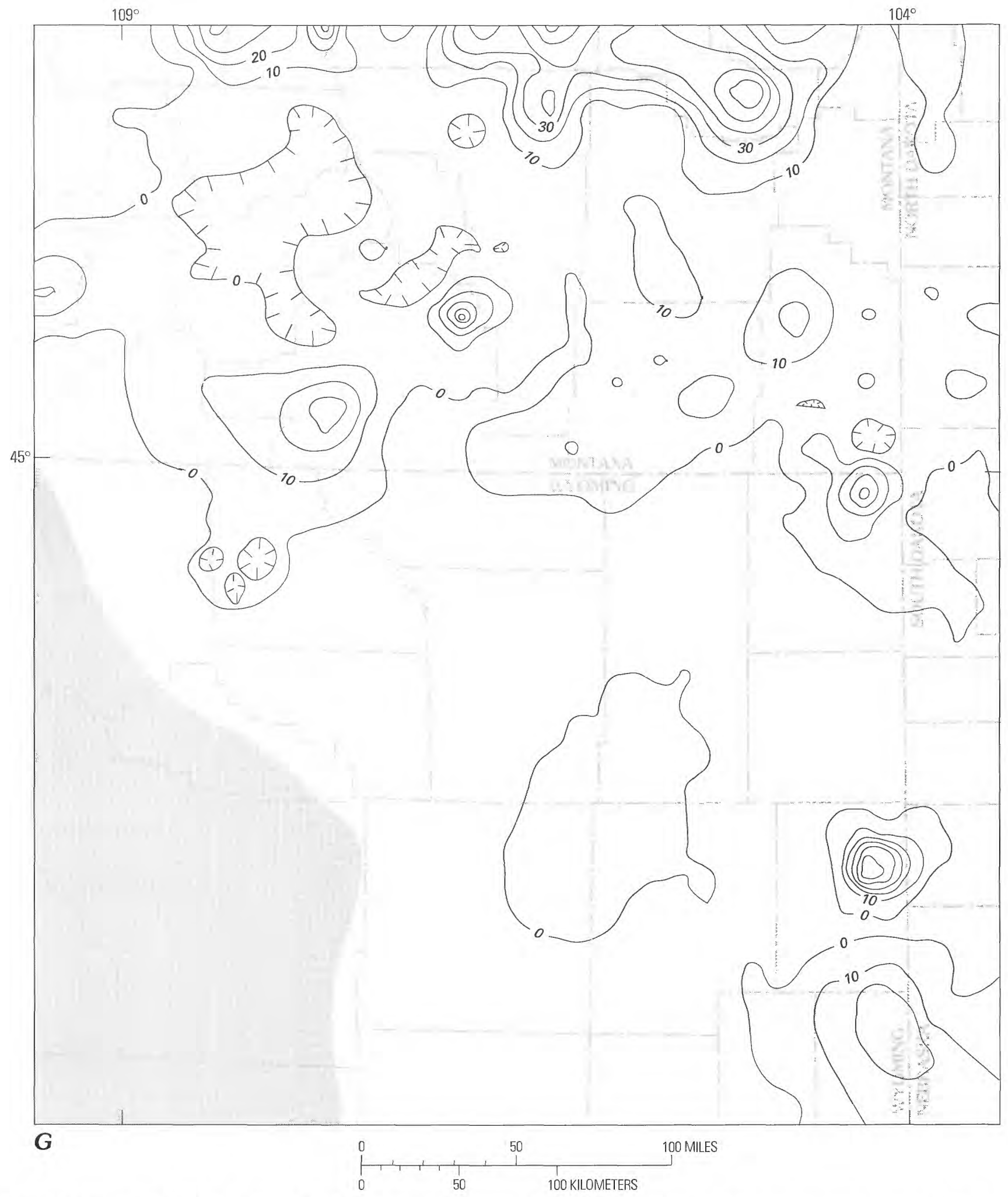

Figure 50 (continued). Lithology of $M 3-M 7$ interval of stratigraphic sequence four (Lower Mississippian, approximately lower Osagean). $G$, Bioclastic limestone (contour interval 10 percent). 
crinoidal mounds are present as the lower part of the Mission Canyon. The oolitic facies grades into crinoidal limestone in north-central Montana, near the southern margin of the Alberta shelf. The Central Montana trough contains anhydrite as thick as $100 \mathrm{ft}(30 \mathrm{~m})$ at the top of the M3-M7 interval. In the rest of study the area, shaly limestone or gray calcareous shale beds of the M7 marker overlie the cycle (Brown and others, 1984; Peterson, 1984).

In most places, crinoidal and oolitic carbonate rocks of the upper part of the Mission Canyon Limestone (fig. 35) dominate the M7-M8.5 interval (middle Osagean) (figs. $49,51,52)$. In the center of the Williston Basin, finegrained limestone and some crinoidal beds are dominant. Oolitic facies along the eastern and southeastern flanks of the Williston Basin in North and South Dakota extend northwest to the area of the general trend of the Central Montana uplift, Miles City arch, and Cedar Creek anticline (fig. 1). Well-developed crinoidal bank facies are present in the area of the Alberta shelf and along the northwestern flank of the Williston Basin (Brown and others, 1984; Peterson, 1984).

The M8.5-M12 interval (upper Osagean) (figs. 39, 53, $54)$ is $150-200 \mathrm{ft}(46-91 \mathrm{~m})$ thick along the flanks of the Williston Basin and is about $400 \mathrm{ft}(122 \mathrm{~m})$ thick in the Central Montana trough and in the interior of the Williston Basin. In some places pre-Kibbey Formation or pre-Jurassic erosion has removed this interval. Carbonate rocks of the Mission Canyon grade into halite, anhydrite, carbonate, and some shale beds that make up the Charles Formation in the center of the Williston Basin. Several porous carbonate beds are present along the eastern and southeastern flanks of the Williston Basin and along the Bighorn-Pryor Mountains belt (fig. 1) (Brown and others, 1984; Peterson, 1984).

The M12-Mc interval (approximately Meramecian) (figs. 40, 55, 56) contains the major part of the "Charles salt" of the Williston Basin. Halite beds grade into interbedded anhydrite, fine-grained dolomite, and thin oolitic limestone outward from the basin center. Pre-Kibbey or pre-Jurassic erosion has removed varied amounts of the interval, especially around the flanks of the Williston Basin. Beds of the M12-Mc interval are generally present only in the Central Montana trough and the central Williston Basin, where more than $500 \mathrm{ft}(152 \mathrm{~m})$ of halite, anhydrite, and some shale make up the section (Brown and others, 1984; Peterson, 1984).

\section{Devonian through Mississippian Structural Trends}

Lower Devonian rocks are only present in the Powder River Basin area as isolated remnants of the Beartooth Butte Formation. The Beartooth Butte probably represents estuarine deposition in an embayment along the Devonian shoreline connected to the Cordilleran miogeocline westward and to the Williston Basin eastward.

Middle and Upper Devonian rocks overlie the Silurian Interlake Formation unconformably in the Williston Basin (Stearns, 1953, 1956; Roehl, 1967) (the Silurian and Upper Devonian sections were considered conformable by Porter and Fuller, 1959, and by Brindle, 1960) and Ordovician and older rocks throughout most of the remainder of the Rocky Mountain area. The Devonian thins uniformly southward across northern and northeastern Montana toward the Central Montana uplift along the Little Belt and Big Snowy Mountains and Porcupine Dome (figs. 42, 57). A second prominent belt of thinning is across the crest of the Cedar Creek anticline (Peterson, 1984). Other important tectonic features influencing Late Devonian sedimentation on the Wyoming shelf were the shelf itself and a linear uplift along the trend of the Wasatch line (the Wyoming arch of the present paper, fig. 5). The Central Montana uplift and Cedar Creek anticline show marked structural growth during the Devonian. Along the axes of these structures, the Devonian section and the upper part of the Silurian section are missing because of deep erosion during latest Devonian or Early Mississippian (Peterson, 1984).

Devonian sections at Warm Springs Canyon and Jakes Fork near Dubois, Wyoming, rest on a small ancestral high, which was probably an emergent nearshore island during earliest Late Devonian (Darby Formation) deposition. Near Rock Springs, Wyoming, abundant sandstone in the Darby is probably the result of proximity to the Late Devonian shoreline and a supply of sand from the Devonian Uinta high. A combination of transgressive onlap, erosional truncation, and eastward depositional thinning controlled the eastern edge of the Darby Formation (Benson, 1966).

Lower and lower Upper Mississippian rocks (Kinderhookian through middle(?) Meramecian) (figs. 38-40) represent a time of relative quiet, decreased clastic influx, and widespread carbonate deposition. The Late Mississippian (late? Meramecian) is a period of regression on the Wyoming shelf (Maughan, written commun., 1991). The clastic Darwin Sandstone Member in the Powder River Basin and nearshore-marine carbonaceous, siliceous, and calcareous rocks of the Big Snowy Group (upper Meramecian? and Chesterian) in the Central Montana trough to the north of the basin represent Late Mississippian deposition.

The Madison Group is thickest in the Williston Basin and the Central Montana (Big Snowy) trough (figs. 1, 47, $49,51,53,55,58)$. These areas also contain the thickest evaporite sequences and were the areas of greatest subsidence. The western projection of the anhydrite of the middle part of the Madison below the M8.5 marker interval is within the Central Montana trough and pinches out to the north and south. On the Alberta shelf, to the north, the upper part of the Madison is absent due to nondeposition 


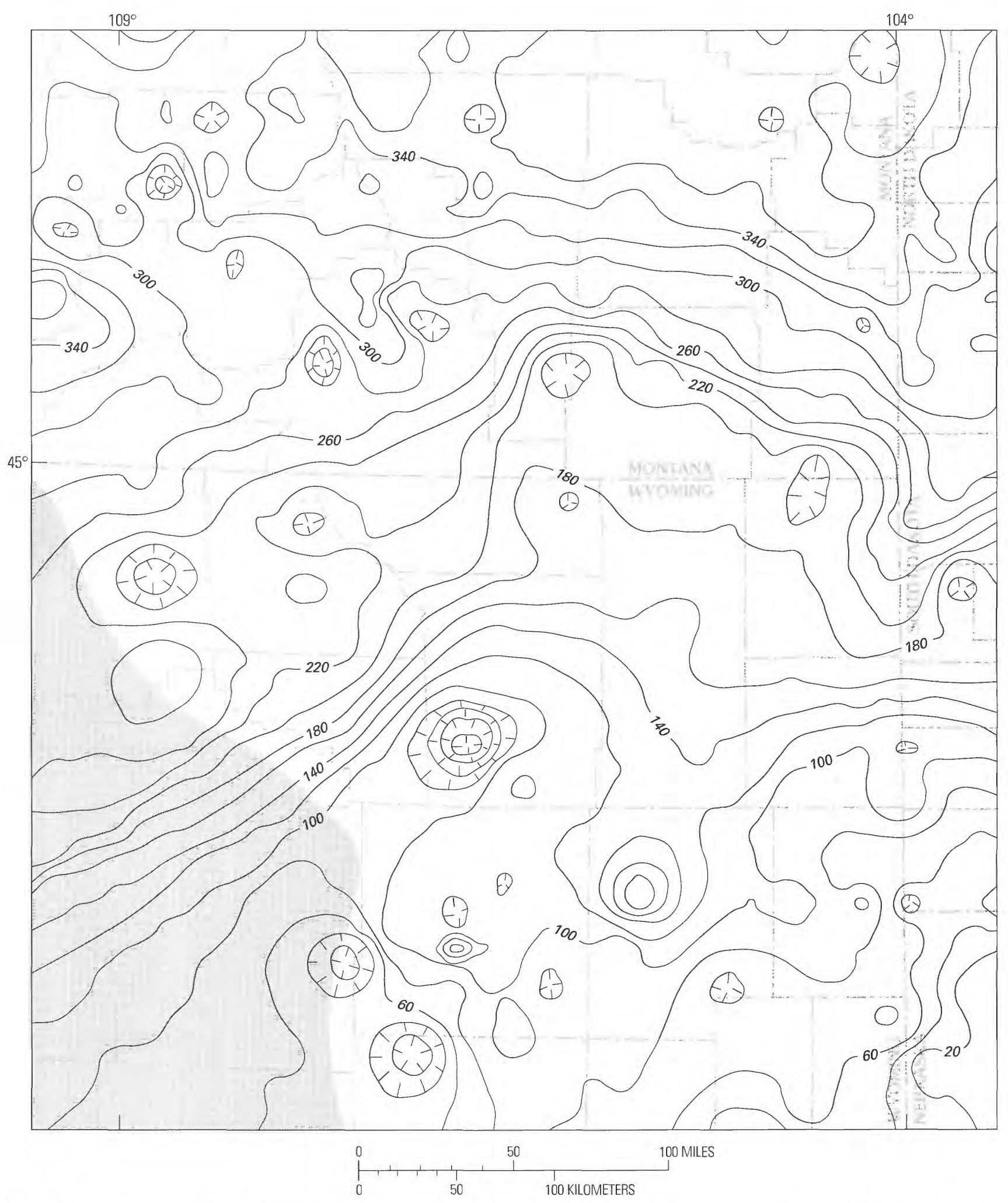

Figure 51. Isopach map of M7-M8.5 interval of stratigraphic sequence four (Lower Mississippian, approximately middle Osagean). Contour interval $20 \mathrm{ft}(6.1 \mathrm{~m})$. Based on 352 wells; gridded on an approximately $7 \mathrm{mi}$ by $7 \mathrm{mi}$ grid $(12 \mathrm{~km}$ by $12 \mathrm{~km})$. Screened area in southwestern part of map area is an area of very limited control. Data modified from Downey (1982). Map area shown in figure 3. 


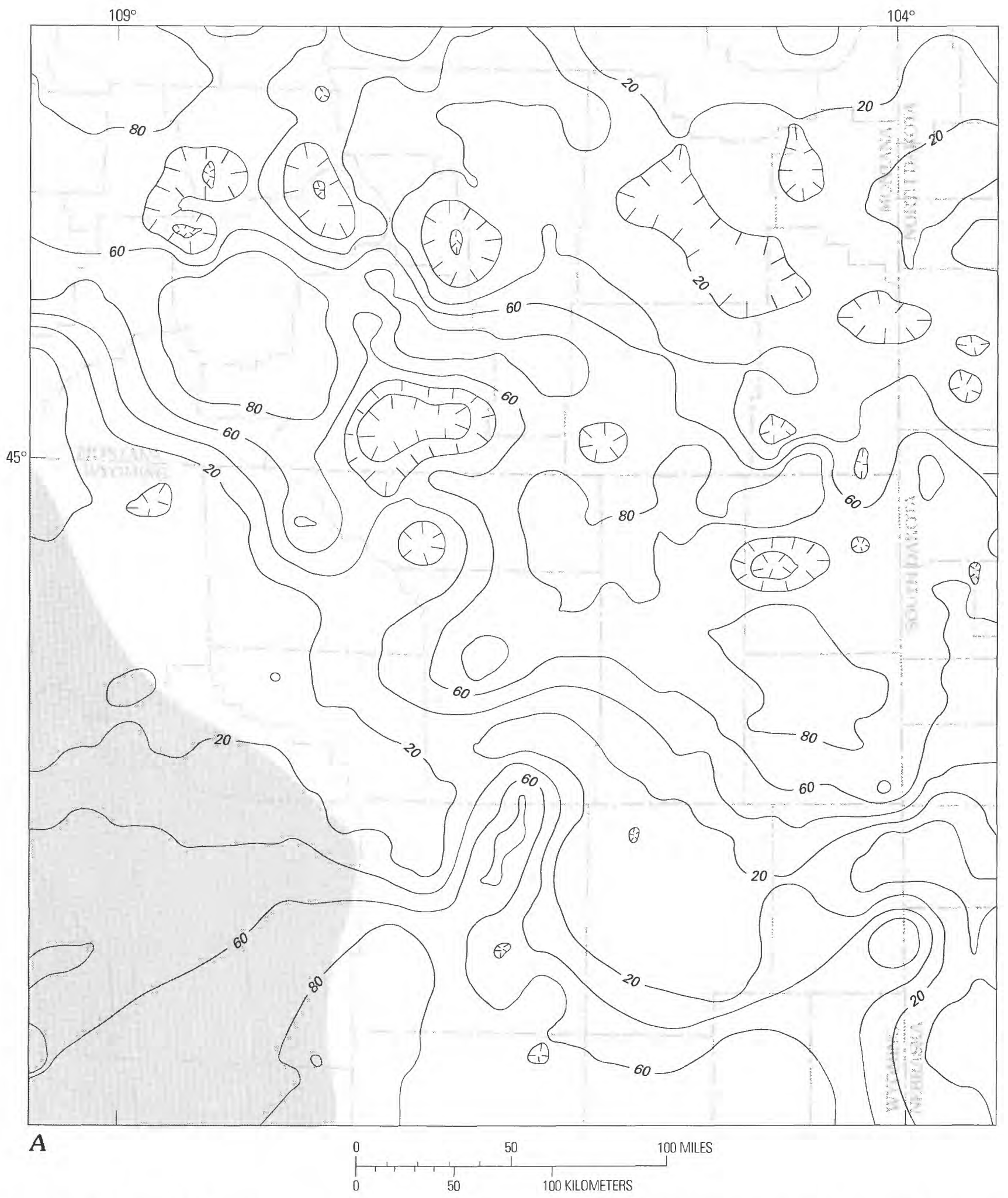

Figure 52. Lithology of M7-M8.5 interval of stratigraphic sequence four (Lower Mississippian, approximately middle Osagean). Based on 281 wells; gridded on an approximately $7 \mathrm{mi}$ by $7 \mathrm{mi}$ grid $(12 \mathrm{~km}$ by $12 \mathrm{~km})$. Screened area in southwestern part of map area is an area of very limited control. Data from Downey (1982). Map area shown in figure 3. A, Dolomite (contour interval 20 percent). 


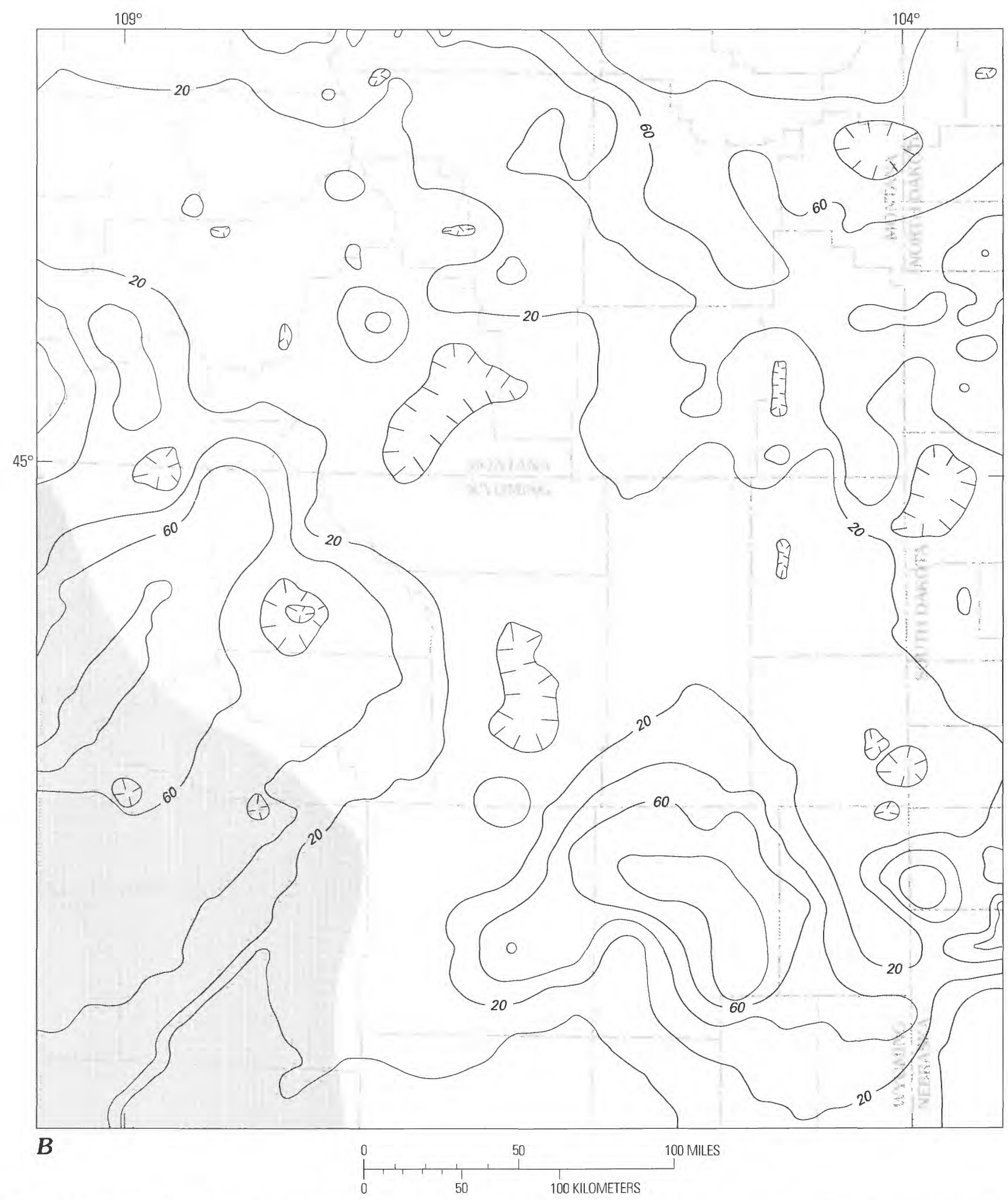

Figure 52 (continued). Lithology of M7-M8.5 interval of stratigraphic sequence four (Lower Mississippian, approximately middle Osagean). B, Limestone (contour interval 20 percent). 


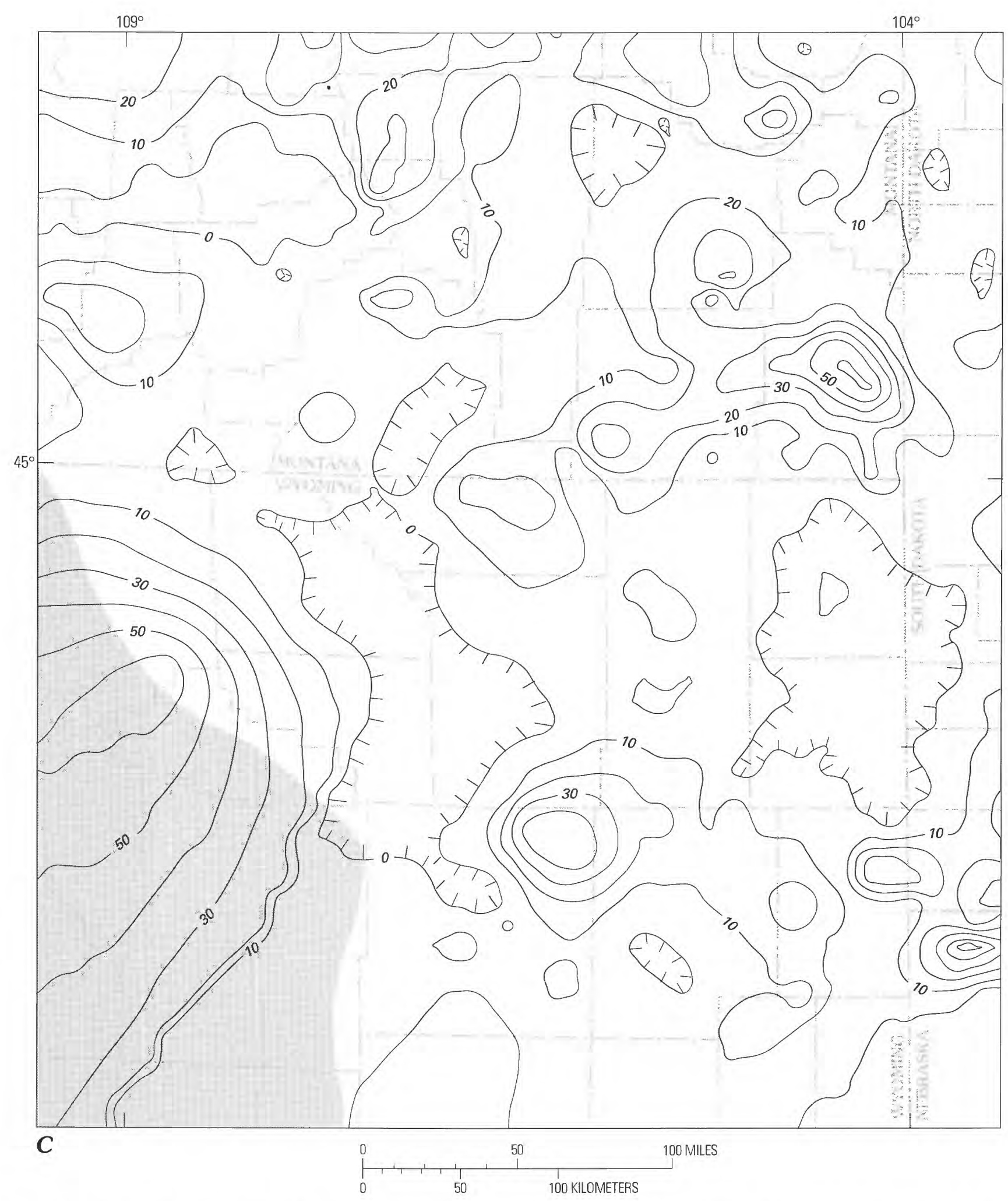

Figure 52 (continued). Lithology of M7-M8.5 interval of stratigraphic sequence four (Lower Mississippian, approximately middle Osagean). C, Oolitic carbonate (contour interval 10 percent). 


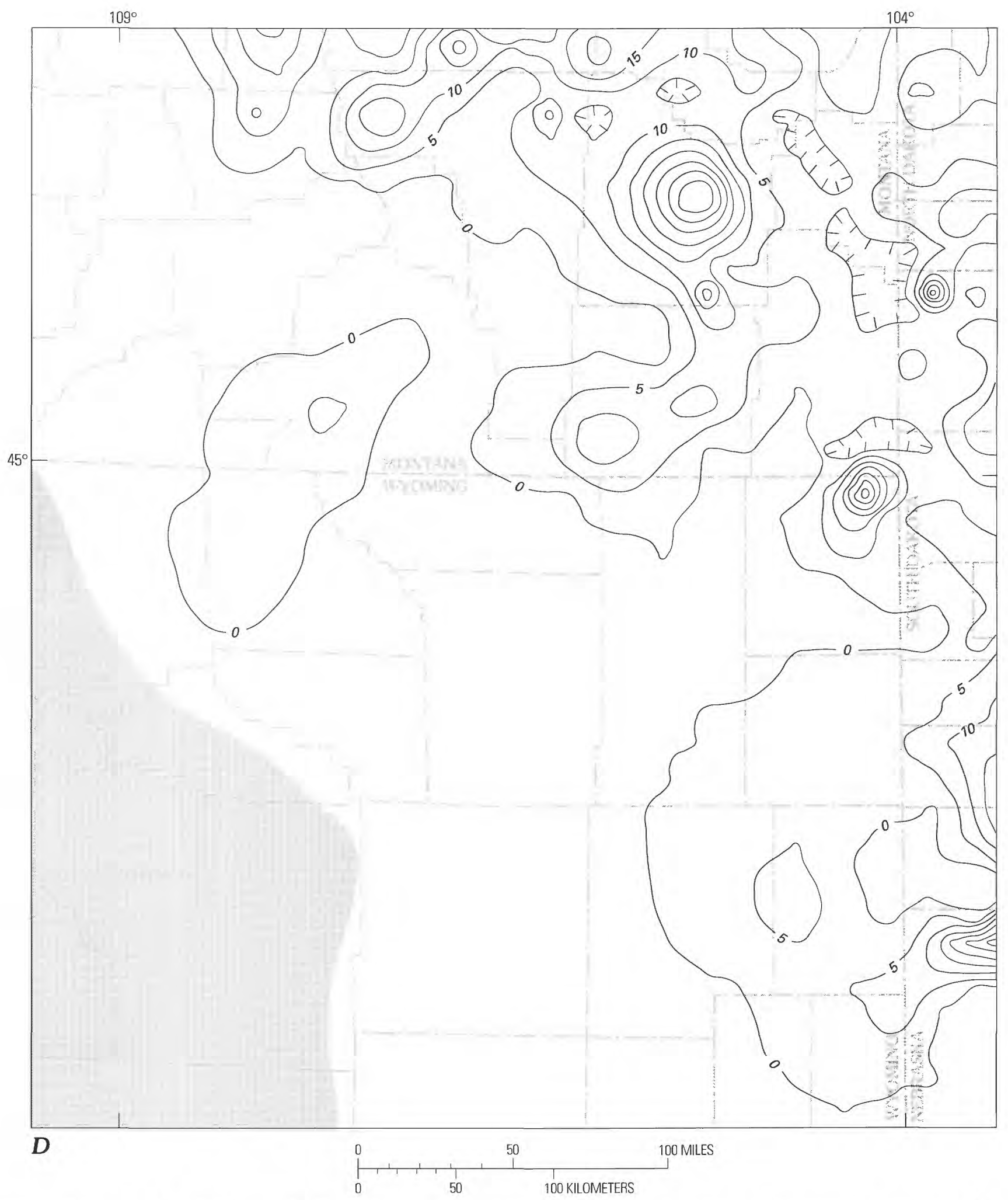

Figure 52 (continued). Lithology of M7-M8.5 interval of stratigraphic sequence four (Lower Mississippian, approximately middle Osagean). $D$, Algal carbonate (contour interval 5 percent). 


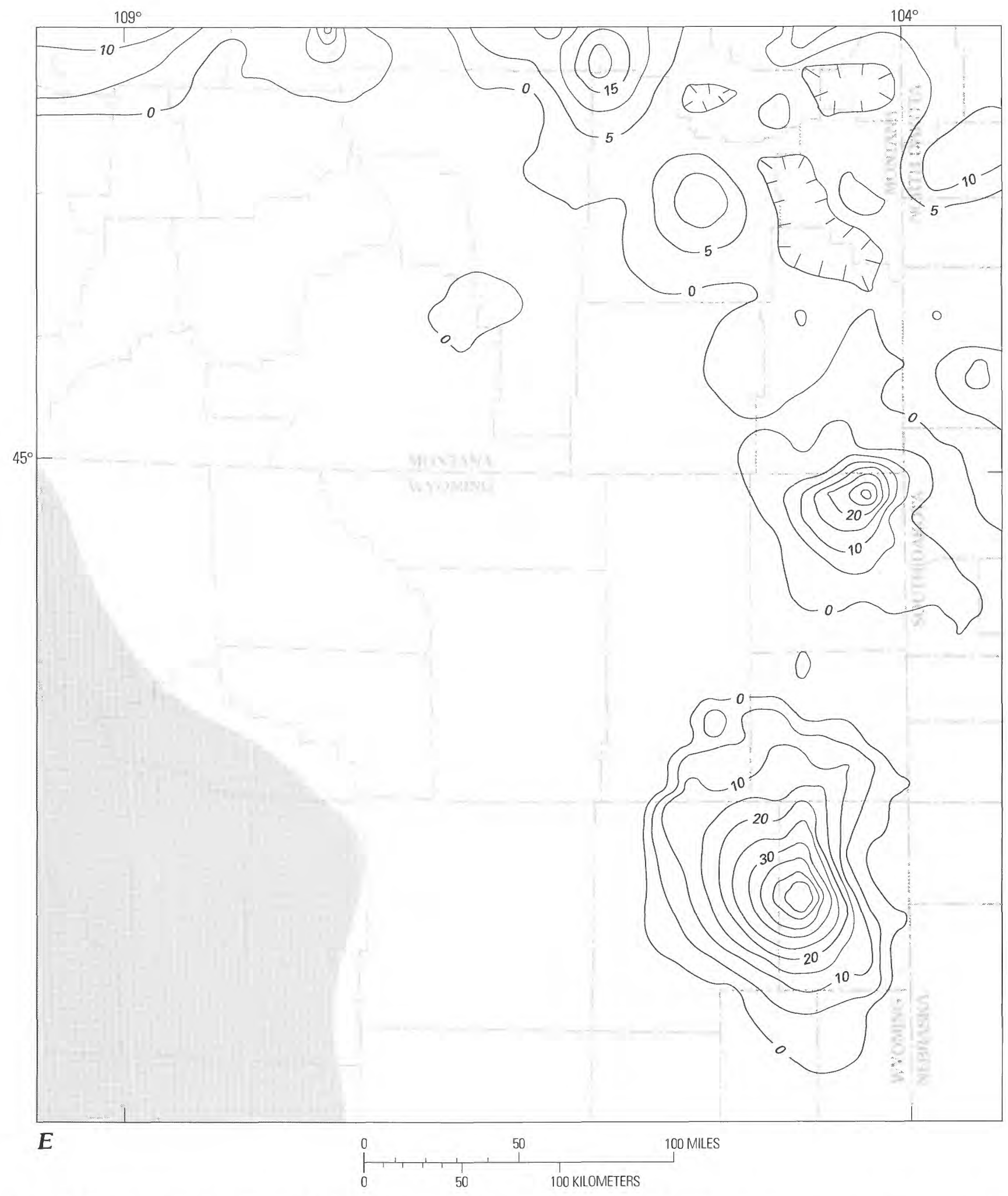

Figure 52 (continued). Lithology of M7-M8.5 interval of stratigraphic sequence four (Lower Mississippian, approximately middle Osagean). E, Crinoidal carbonate (contour interval 5 percent). 


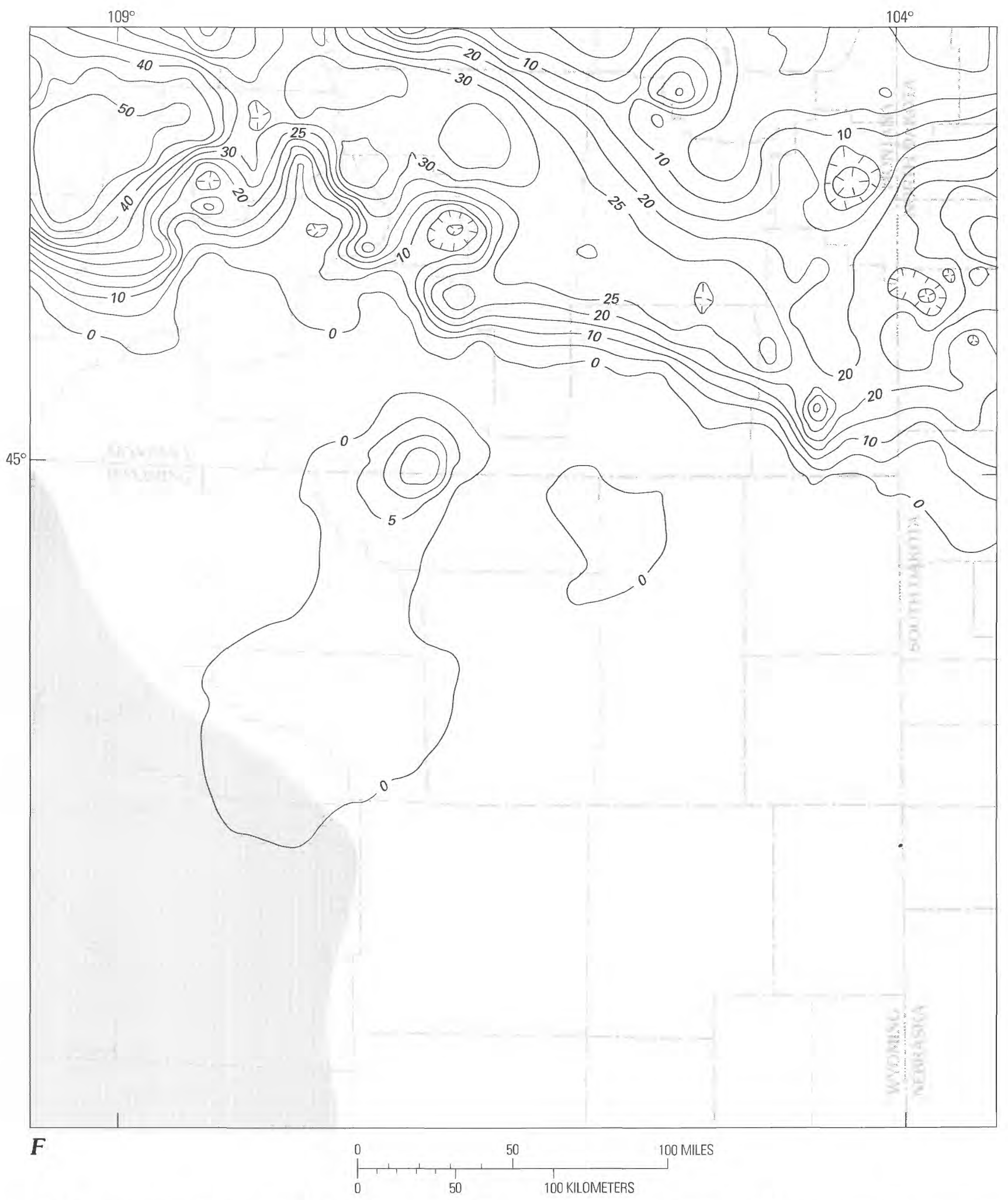

Figure 52 (continued). Lithology of M7-M8.5 interval of stratigraphic sequence four (Lower Mississippian, approximately middle Osagean). F, Evaporite (contour interval 5 percent). 


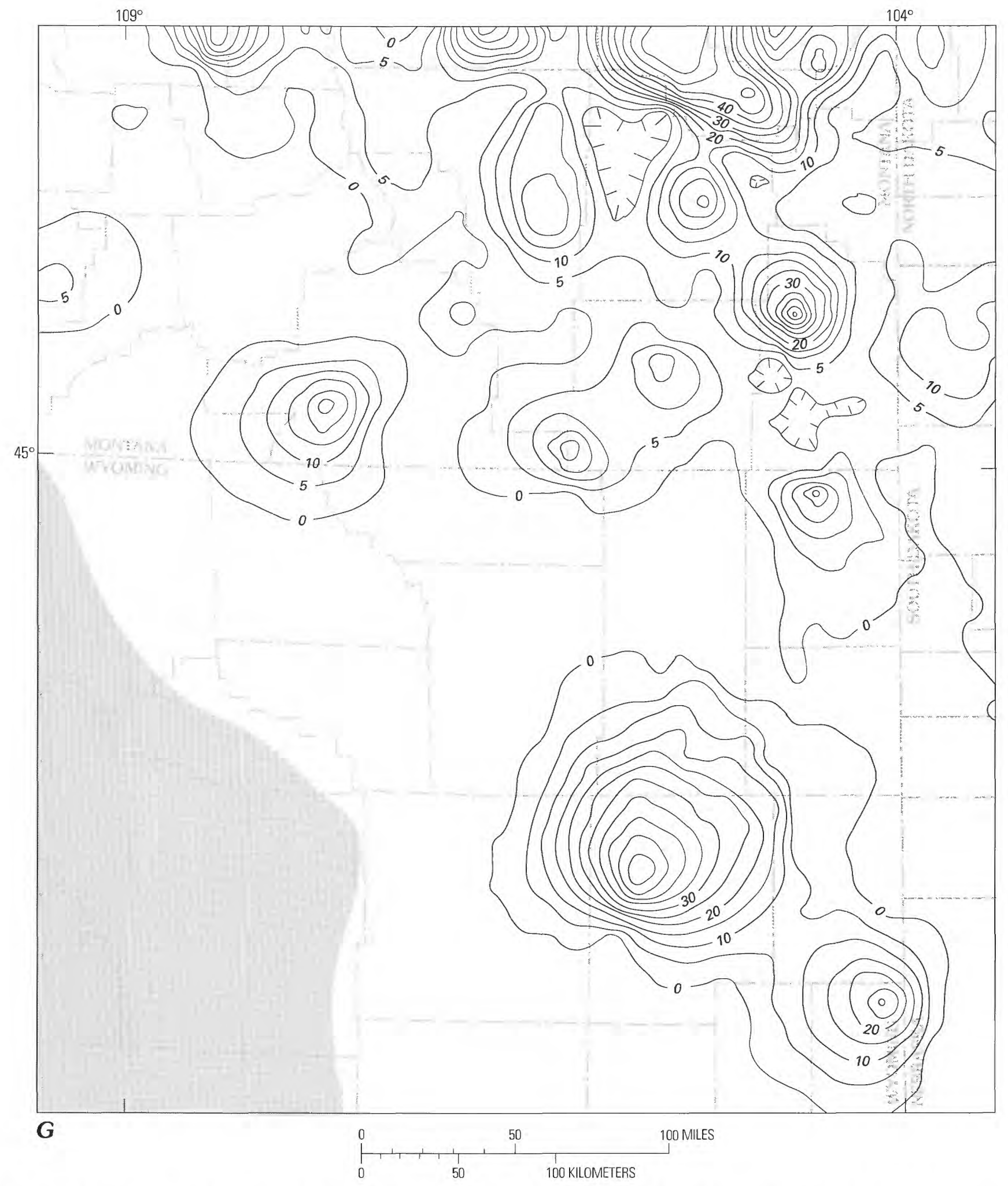

Figure 52 (continued). Lithology of M7-M8.5 interval of stratigraphic sequence four (Lower Mississippian, approximately middle Osagean). $G$, Bioclastic carbonate (contour interval 5 percent). 


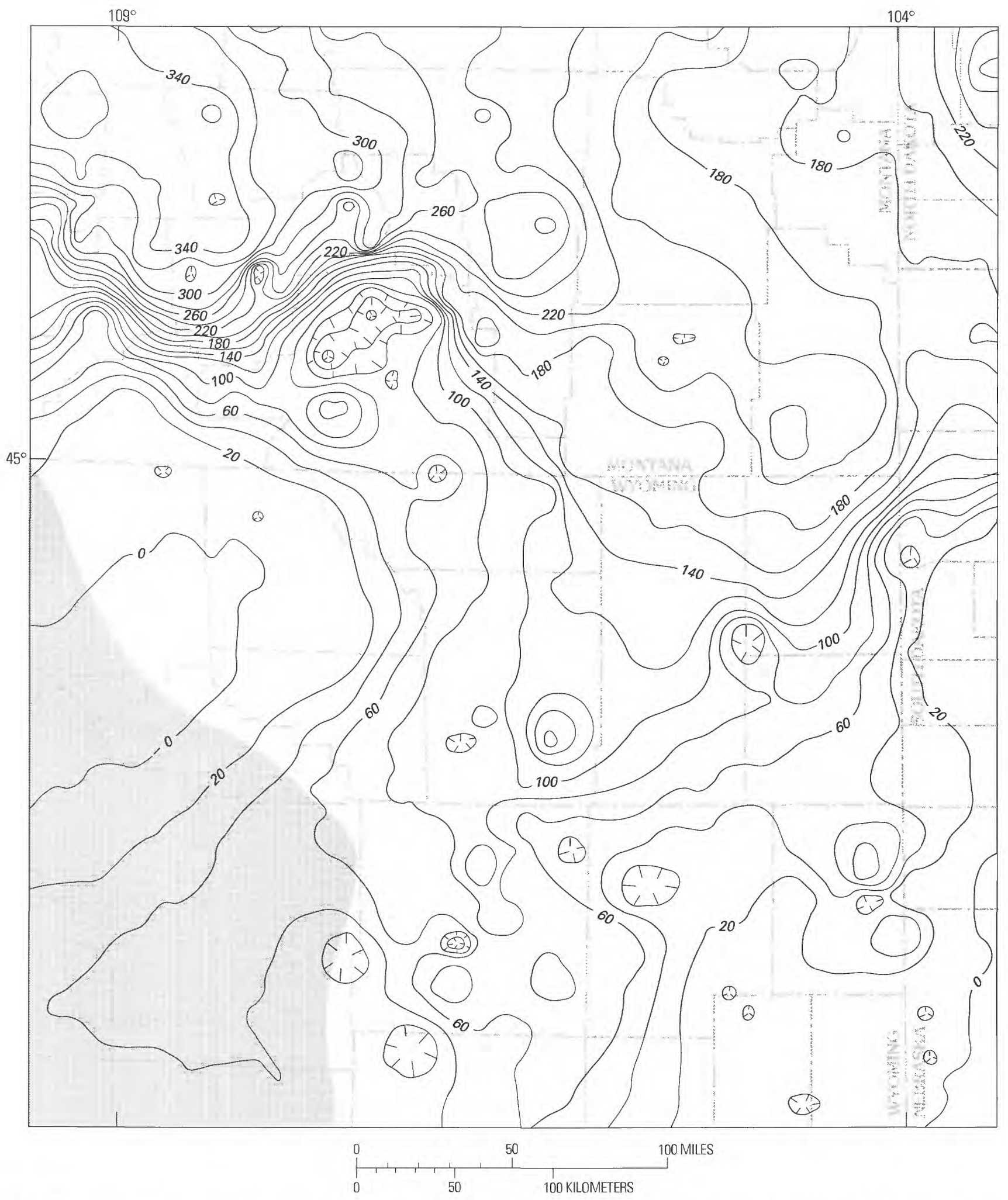

Figure 53. Isopach map of M8.5-M12 interval of stratigraphic sequence four (Lower Mississippian, approximately upper Osagean). Contour interval $20 \mathrm{ft}(6.1 \mathrm{~m})$. Based on 376 wells; gridded on an approximately $7 \mathrm{mi}$ by $7 \mathrm{mi}$ grid (12 km by $12 \mathrm{~km})$. Screened area in southwestern part of map area is an area of very limited control. Data modified from Downey (1982). Map area shown in figure 3. 


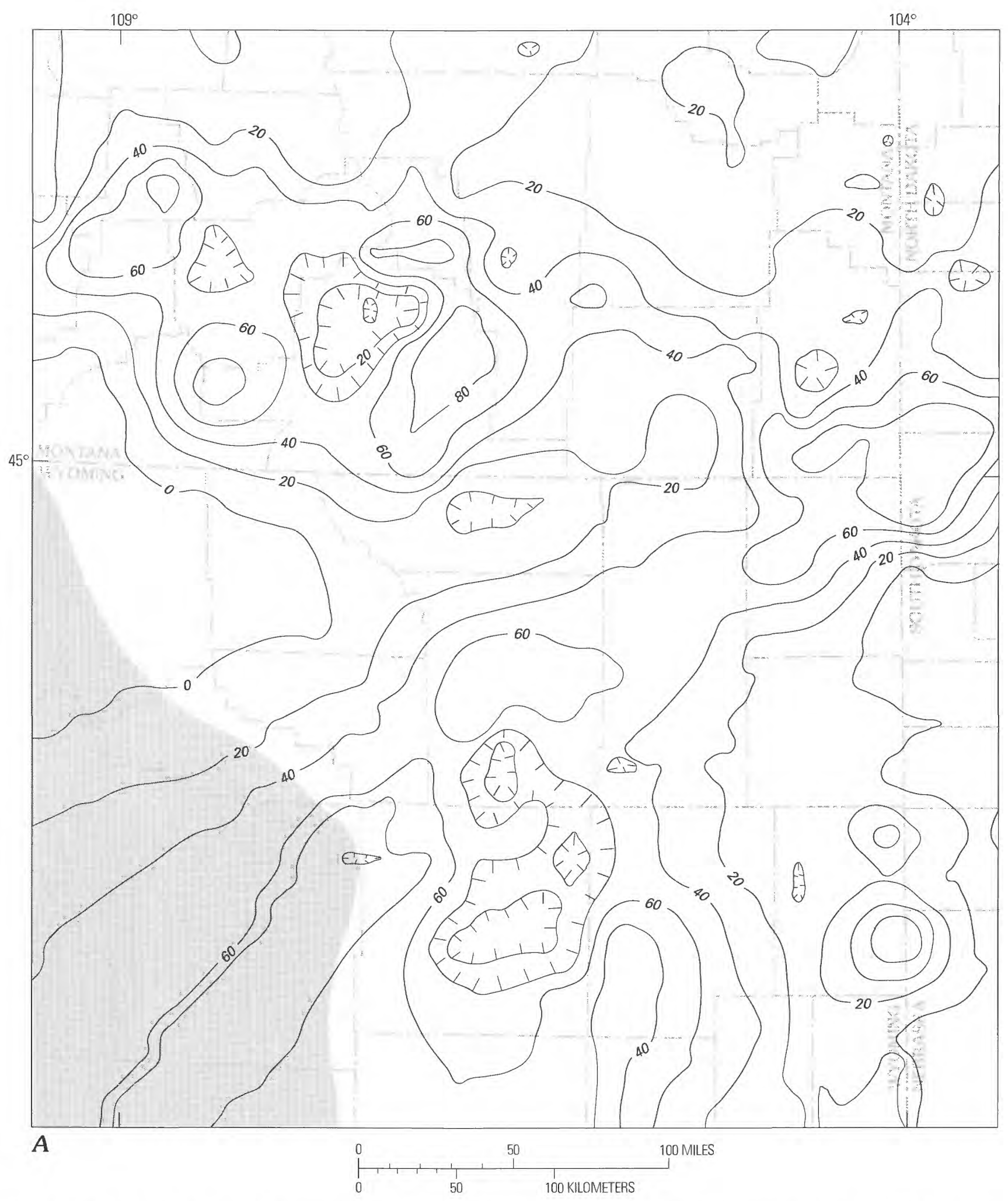

Figure 54. Lithology of M8.5-M12 interval of stratigraphic sequence four (Lower Mississippian, approximately upper Osagean). Based on 272 wells; gridded on an approximately 7 mi by 7 mi grid $(12 \mathrm{~km}$ by $12 \mathrm{~km})$. Screened area in southwestern part of map area is an area of very limited control. Data from Downey (1982). Map area shown in figure 3. A, Dolomite (contour interval 20 percent). 


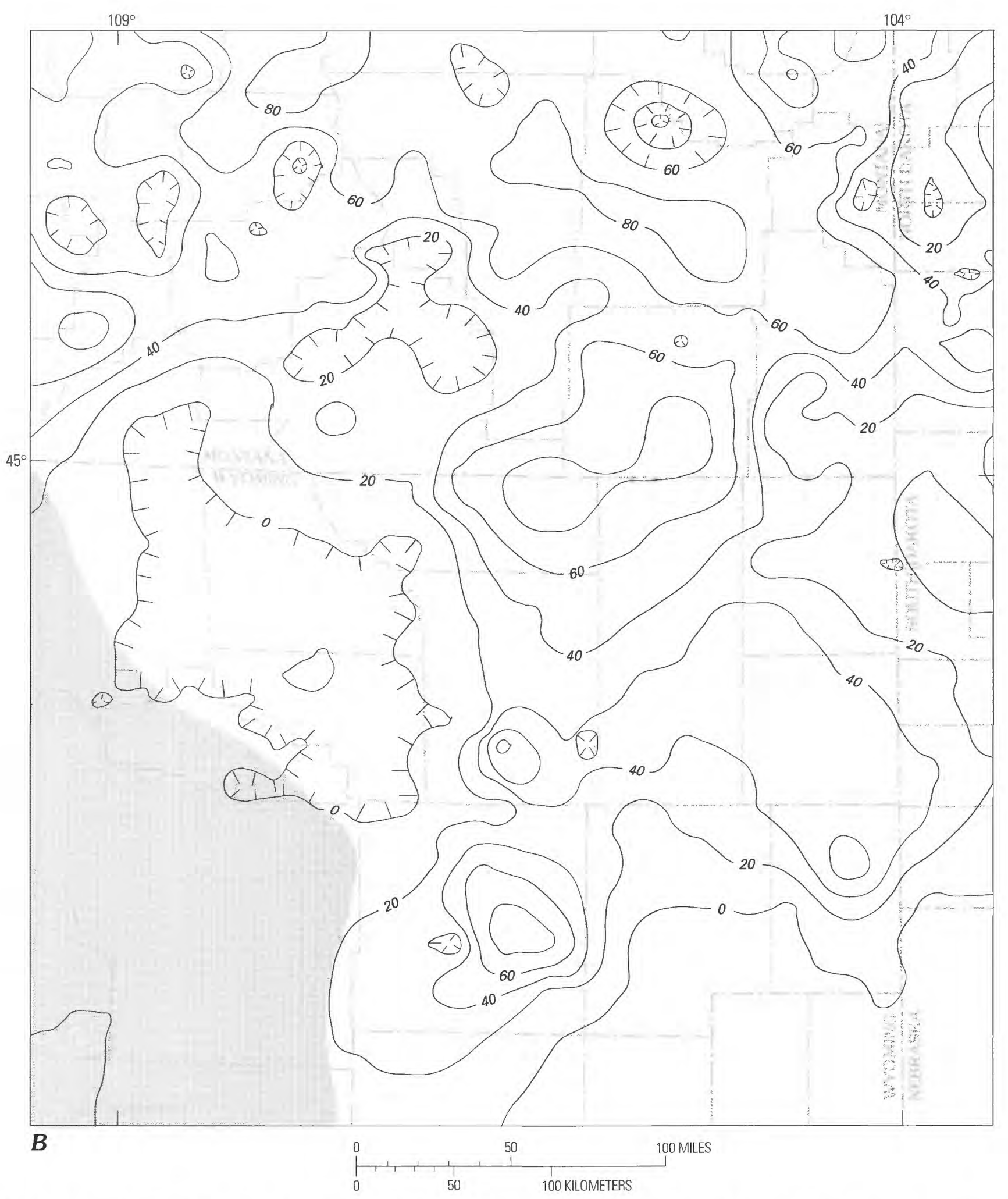

Figure 54 (continued). Lithology of M8.5-M12 interval of stratigraphic sequence four (Lower Mississippian, approximately upper Osagean). B, Limestone (contour interval 20 percent). 


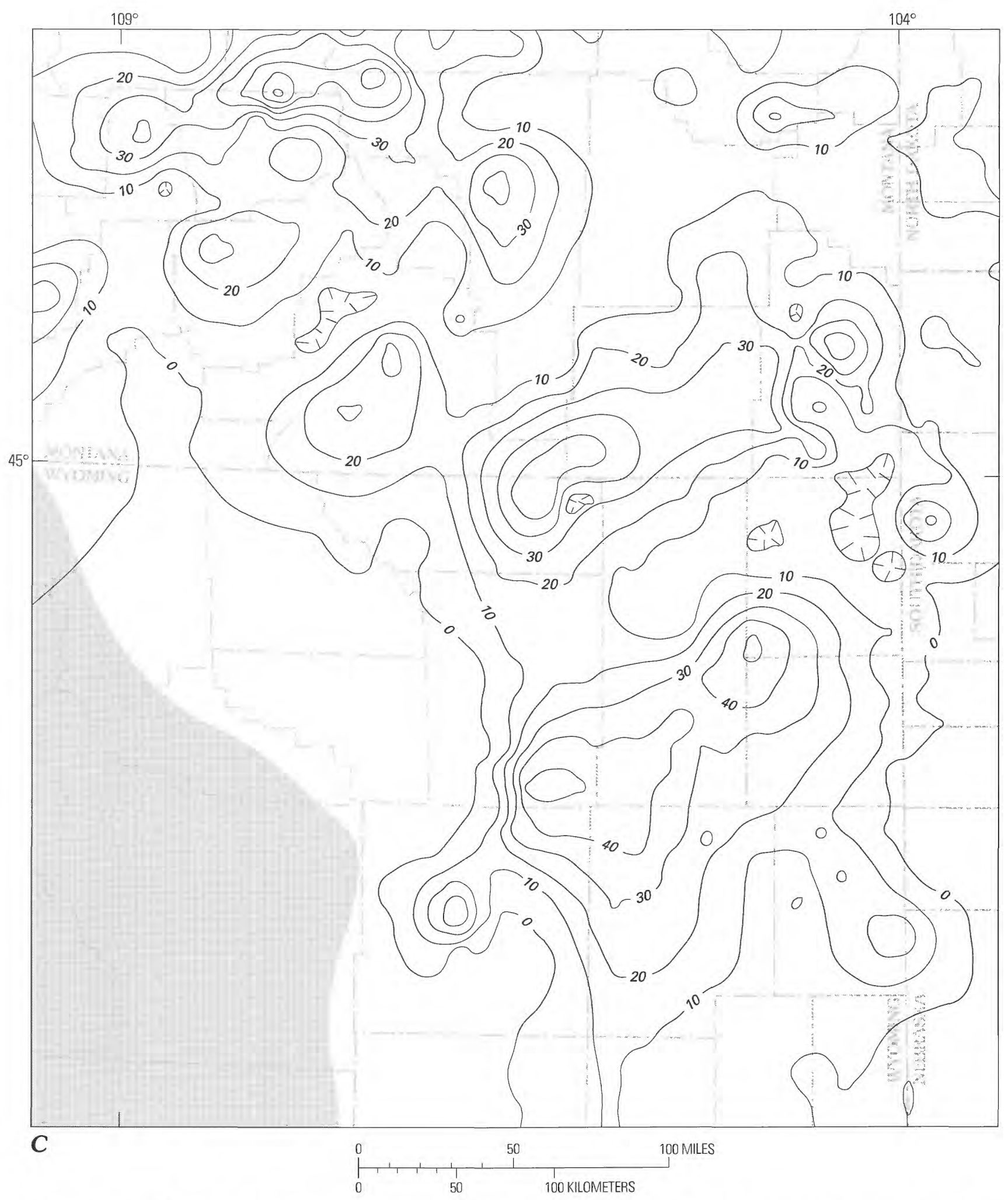

Figure 54 (continued). Lithology of M8.5-M12 interval of stratigraphic sequence four (Lower Mississippian, approximately upper Osagean). $C$, Oolitic carbonate (contour interval 10 percent). 


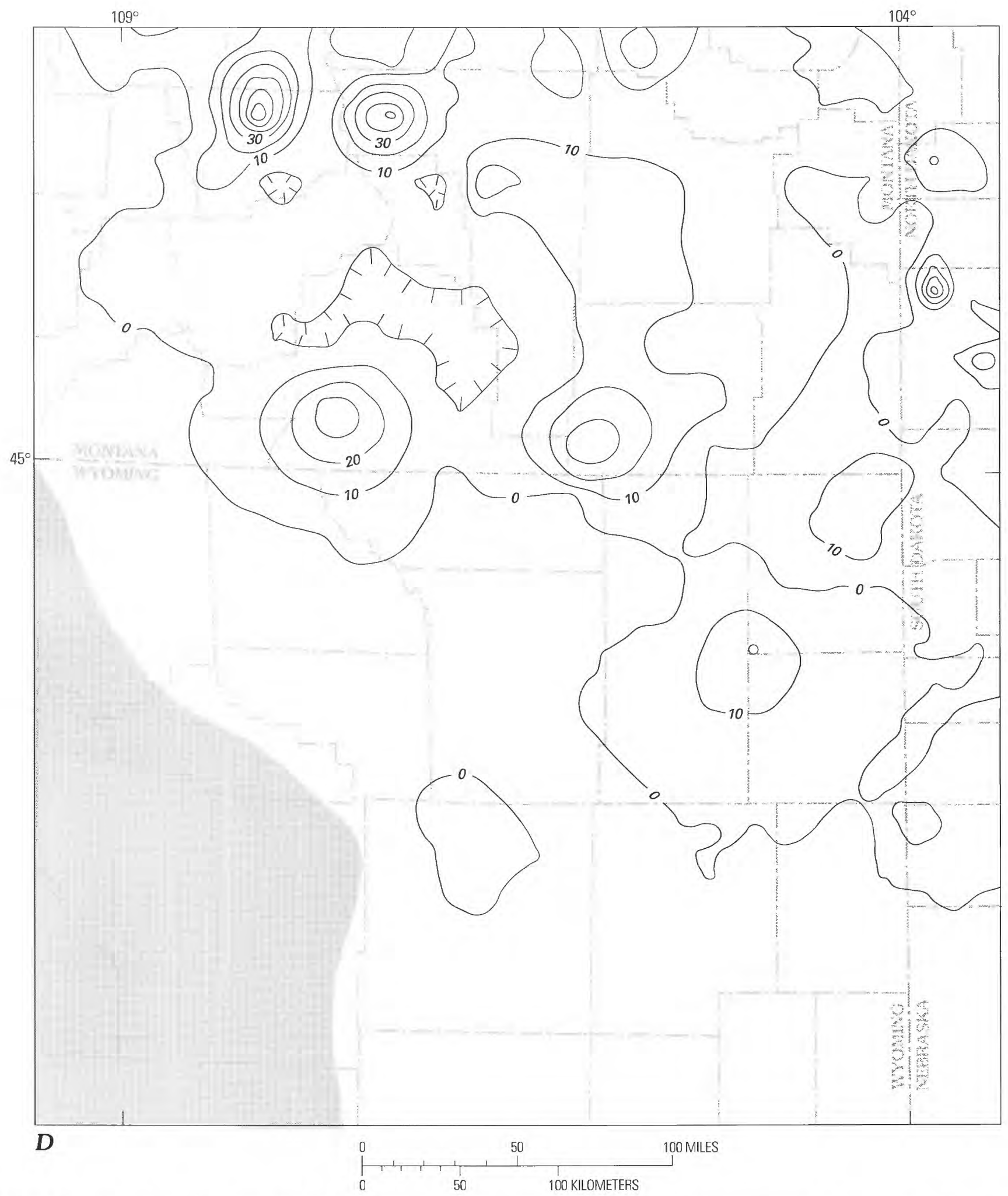

Figure 54 (continued). Lithology of M8.5-M12 interval of stratigraphic sequence four (Lower Mississippian, approximately upper Osagean). $D$, Algal carbonate (contour interval 10 percent). 


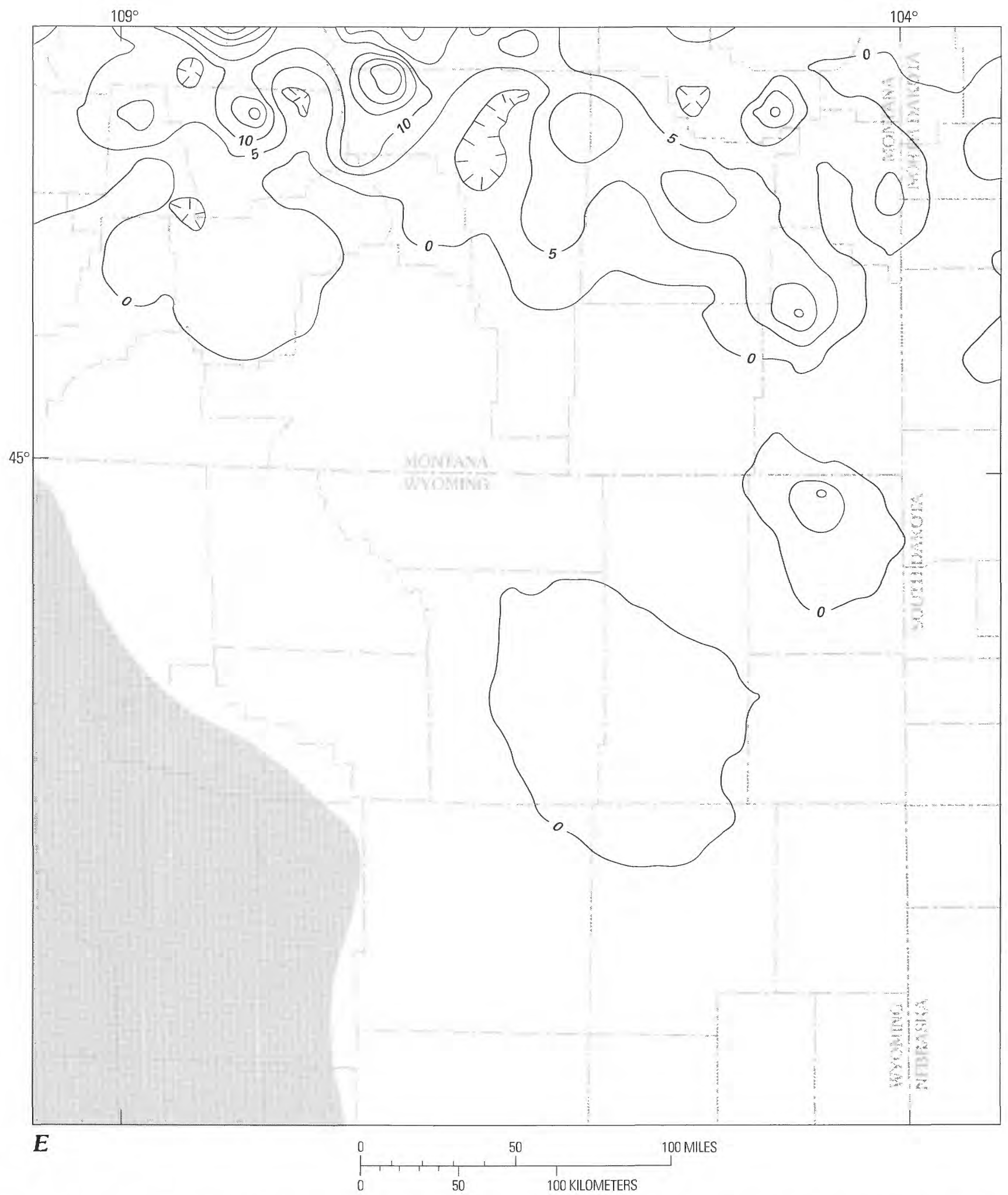

Figure 54 (continued). Lithology of M8.5-M12 interval of stratigraphic sequence four (Lower Mississippian, approximately upper Osagean). E, Crinoidal carbonate (contour interval 5 percent). 


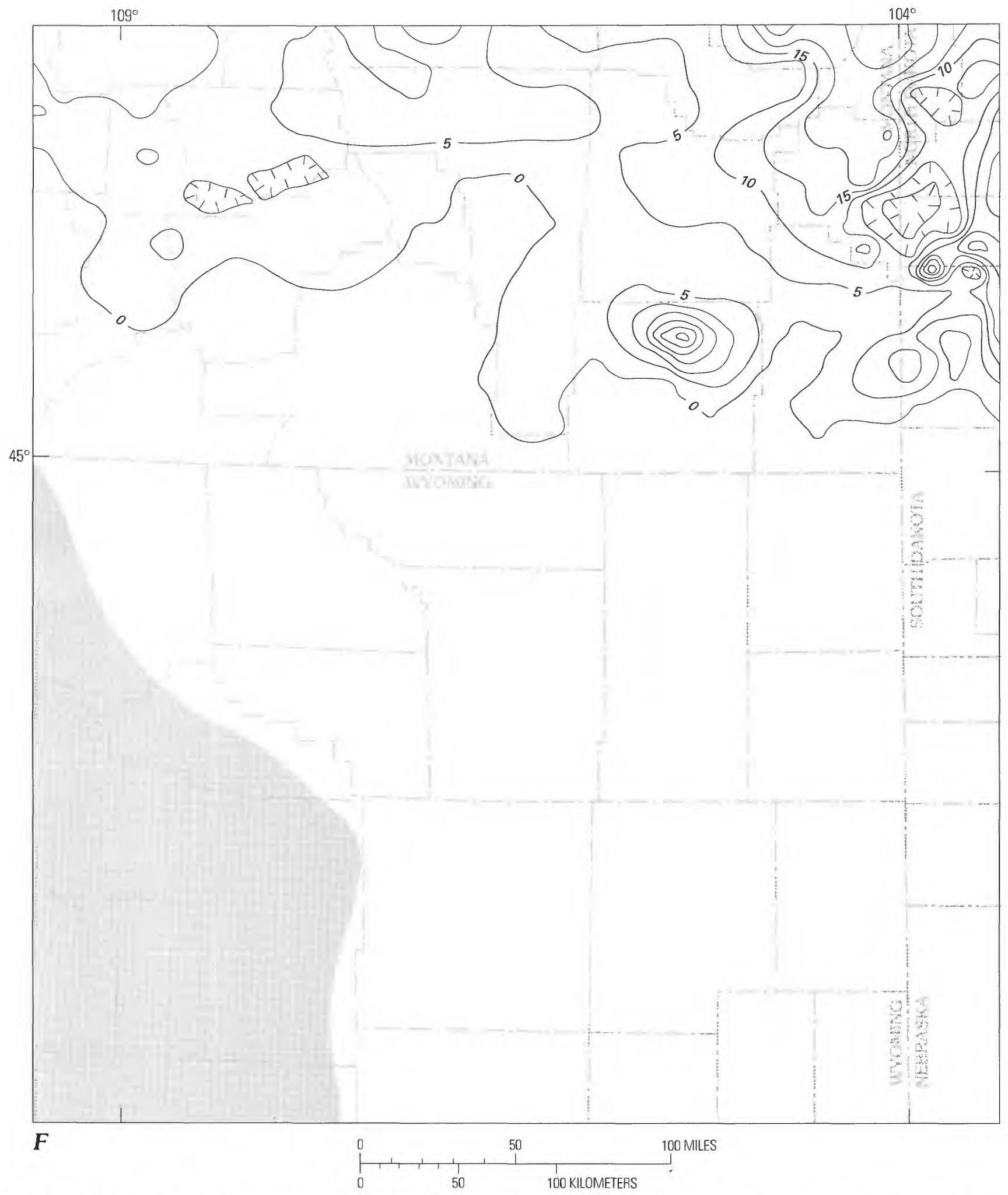

Figure 54 (continued). Lithology of M8.5-M12 interval of stratigraphic sequence four (Lower Mississippian, approximately upper Osagean). F, Evaporite (contour interval 5 percent). 


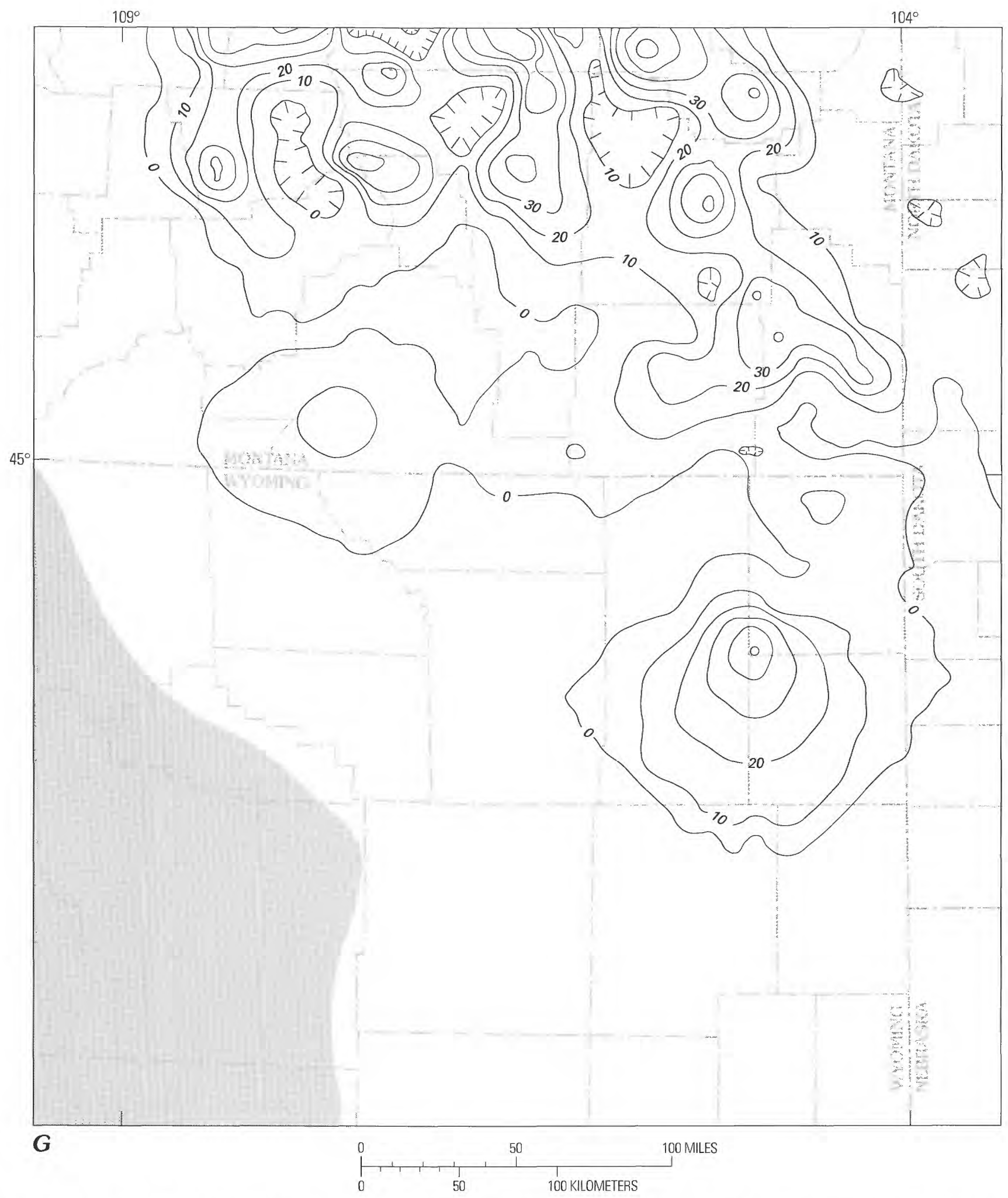

Figure 54 (continued). Lithology of M8.5-M12 interval of stratigraphic sequence four (Lower Mississippian, approximately upper Osagean). $G$, Bioclastic carbonate (contour interval 10 percent). 


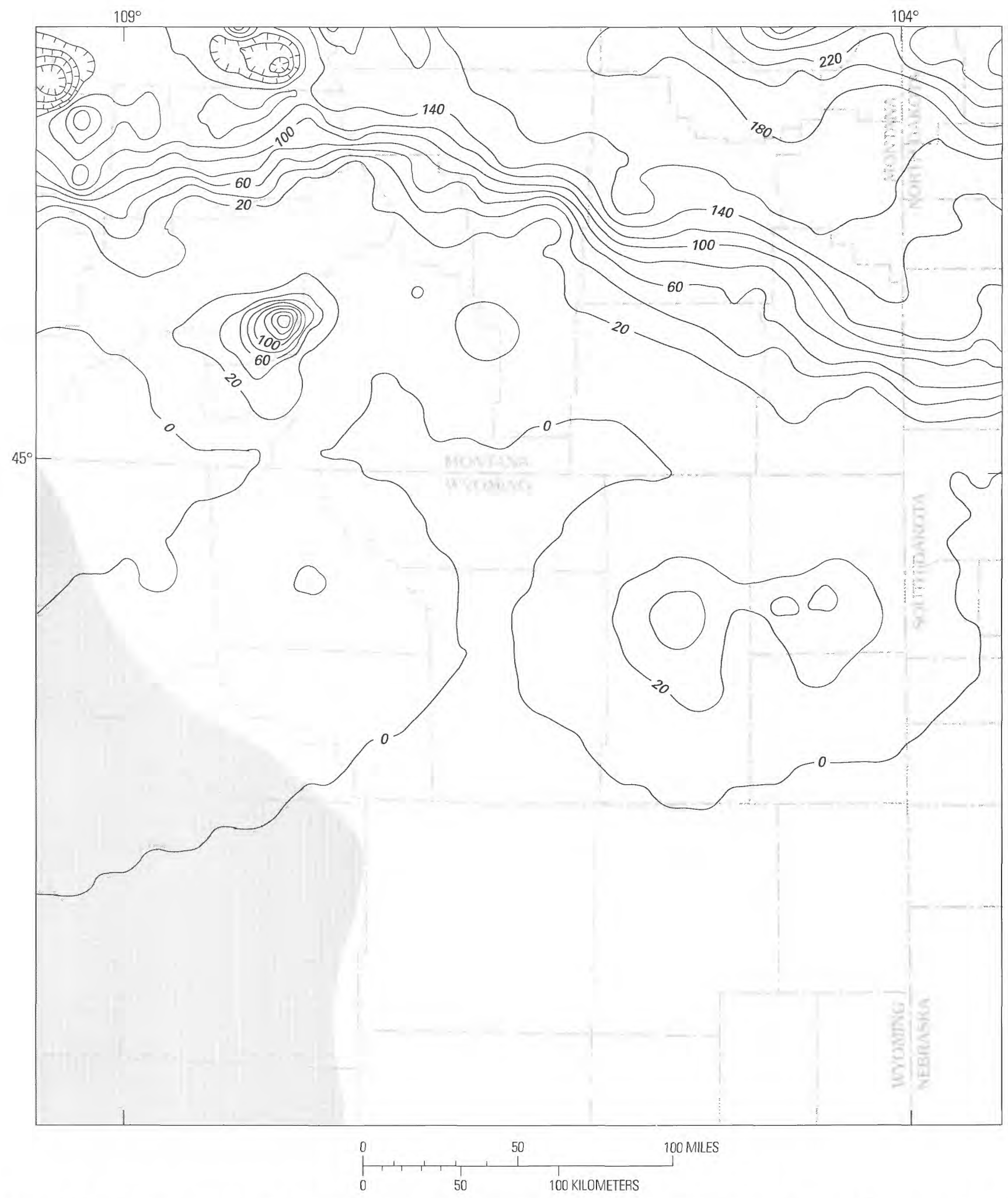

Figure 55. Isopach map of M12-Mc interval of stratigraphic sequence four (Upper Mississippian, lower(?) Meramecian). Contour interval $20 \mathrm{ft}(6.1 \mathrm{~m})$. Based on 398 wells; gridded on an approximately $7 \mathrm{mi}$ by $7 \mathrm{mi}$ grid (12 km by $12 \mathrm{~km})$. Screened area in southwestern part of map area is an area of very limited control. Data modified from Downey (1982). Map area shown in figure 3 . 


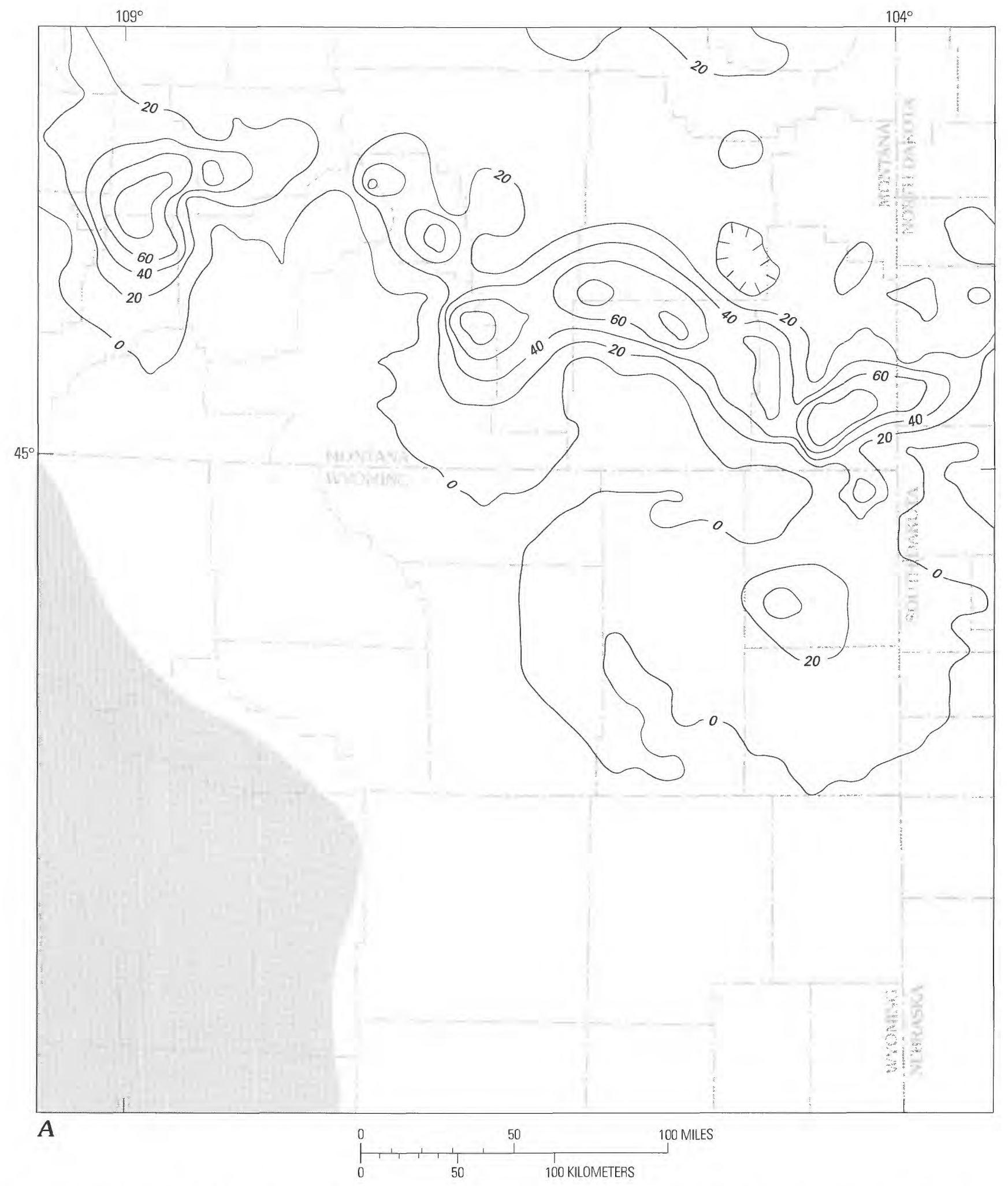

Figure 56. Lithology of M12-Mc interval of stratigraphic sequence four (Upper Mississippian, lower? Meramecian). Based on 272 wells; gridded on an approximately $7 \mathrm{mi}$ by $7 \mathrm{mi}$ grid $(12 \mathrm{~km}$ by $12 \mathrm{~km})$. Screened area in southwestern part of map area is an area of very limited control. Data from Downey (1982). Map area shown in figure 3. A, Dolomite (contour interval 20 percent). 


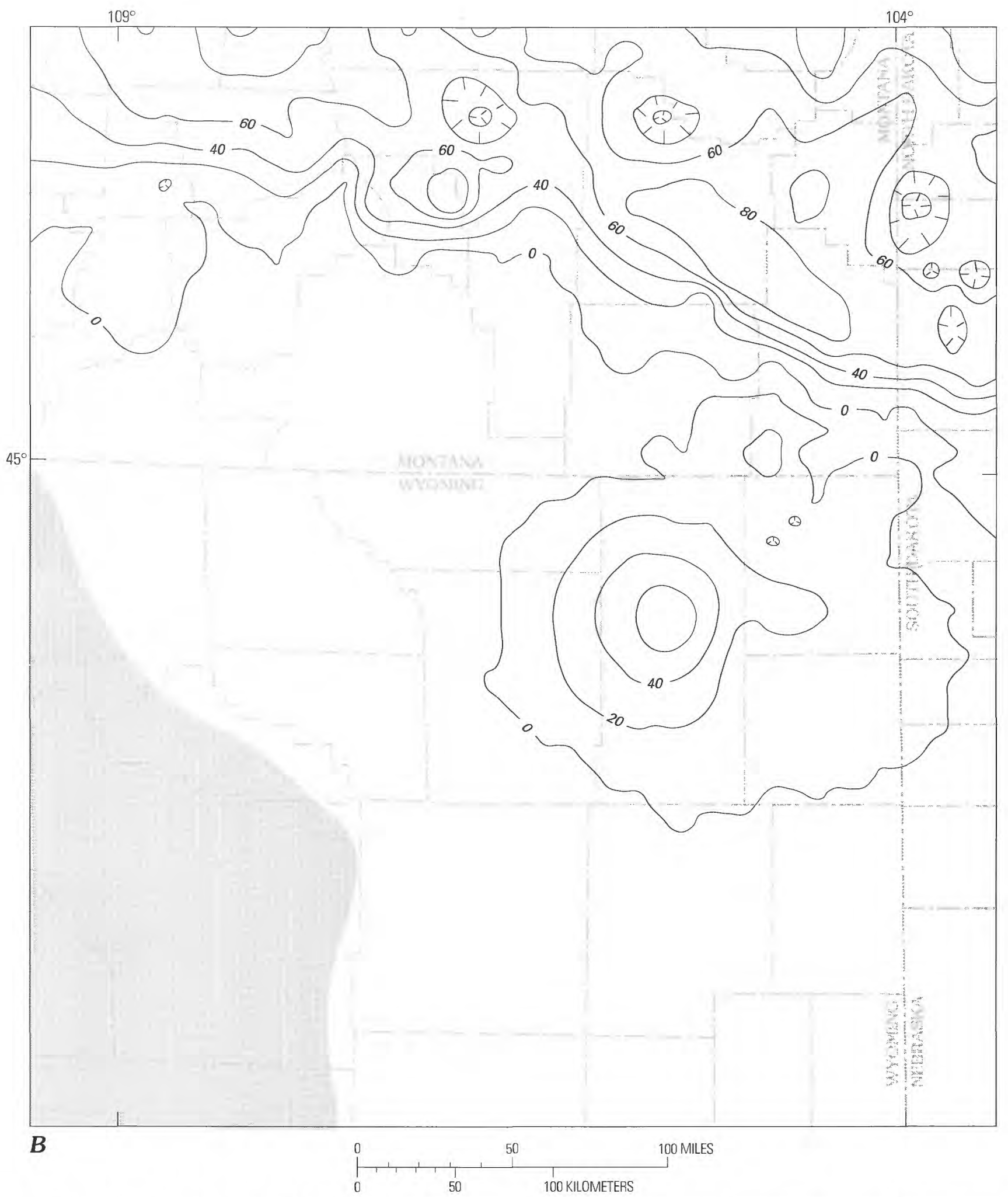

Figure 56 (continued). Lithology of M12-Mc interval of stratigraphic sequence four (Upper Mississippian, lower? Meramecian). B, Limestone (contour interval 20 percent). 


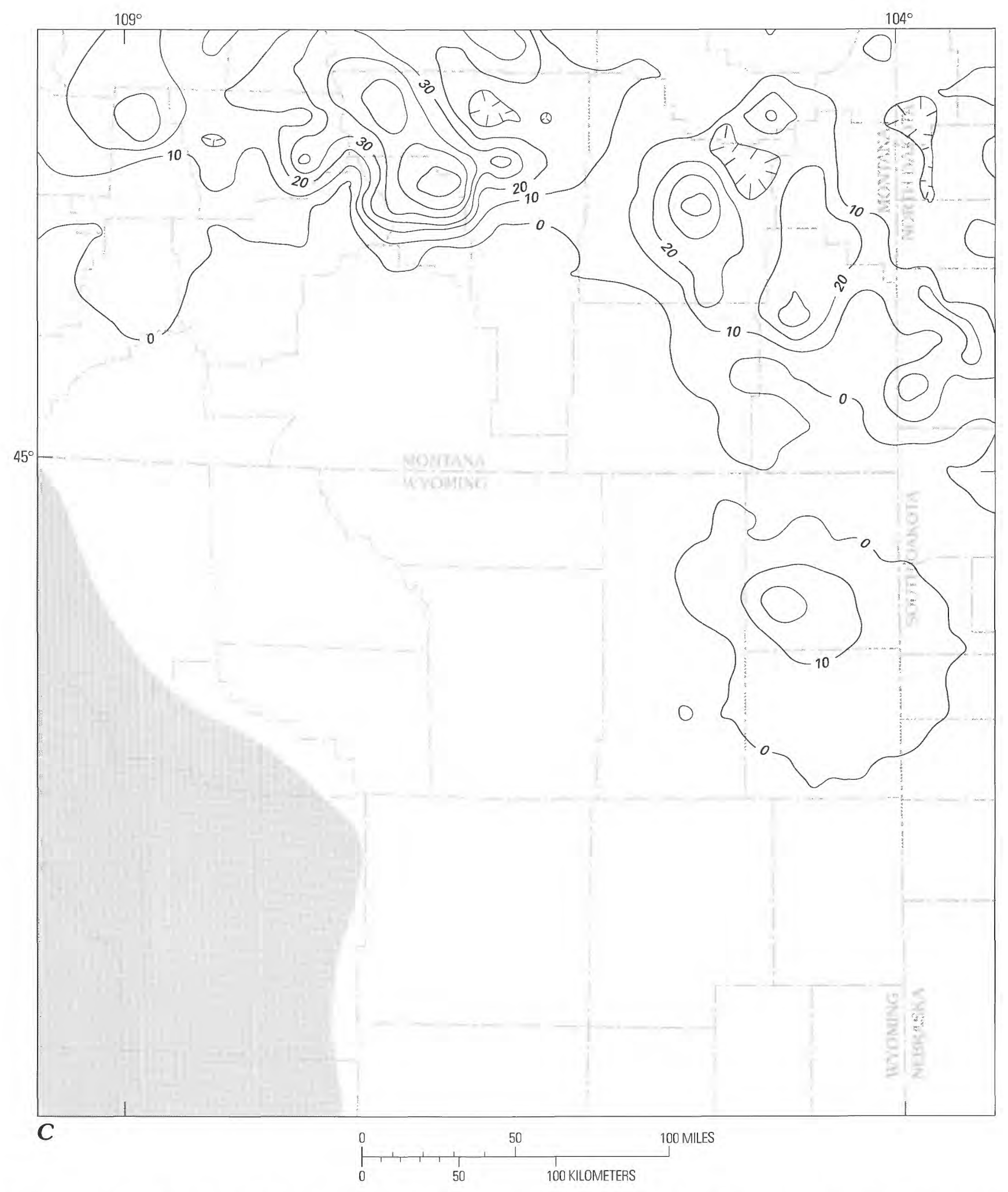

Figure 56 (continued). Lithology of M12-Mc interval of stratigraphic sequence four (Upper Mississippian, lower? Meramecian). C, Oolitic carbonate (contour interval 10 percent). 


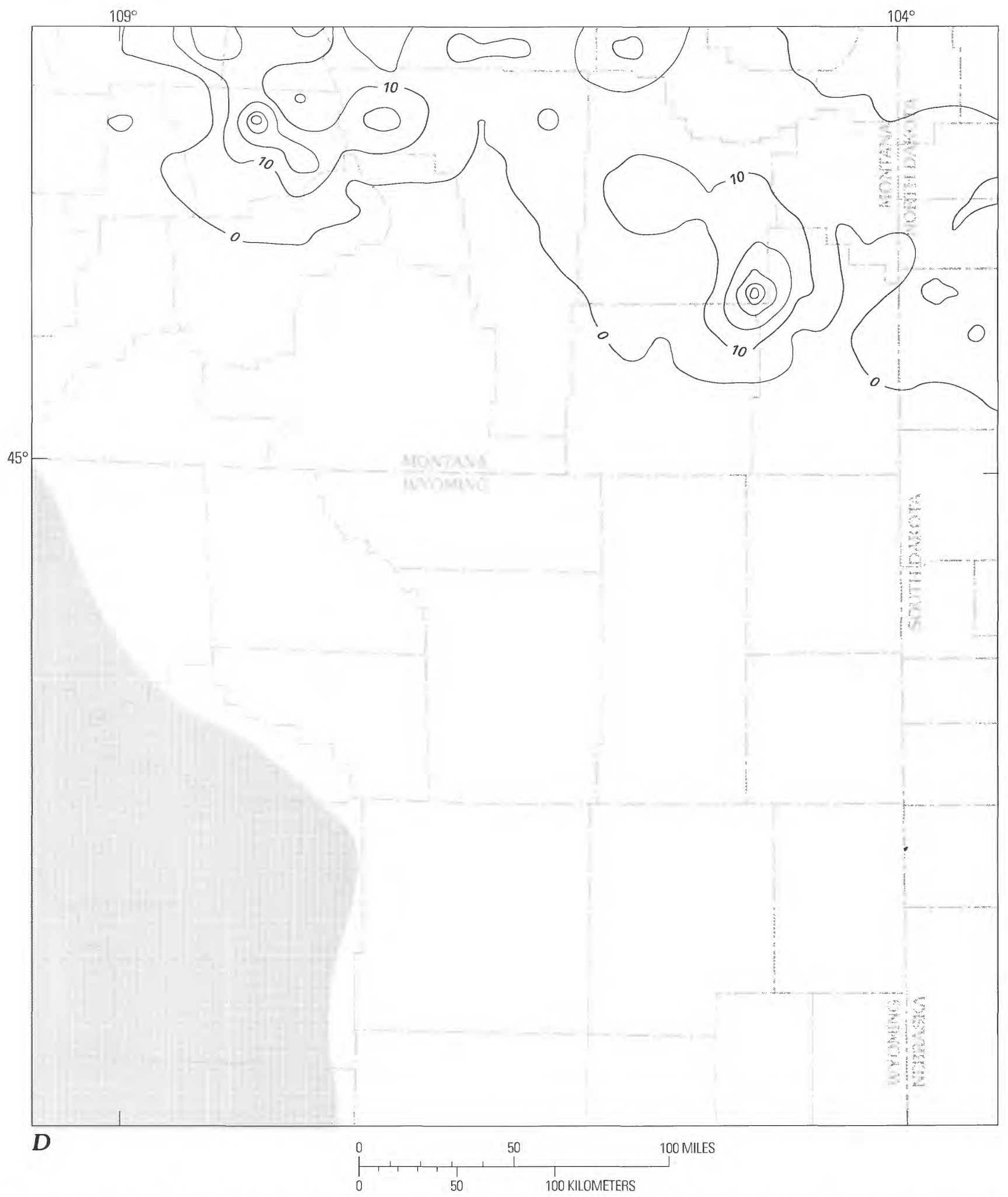

Figure 56 (continued). Lithology of M12-Mc interval of stratigraphic sequence four (Upper Mississippian, lower? Meramecian). $D$, Algal carbonate (contour interval 10 percent). 


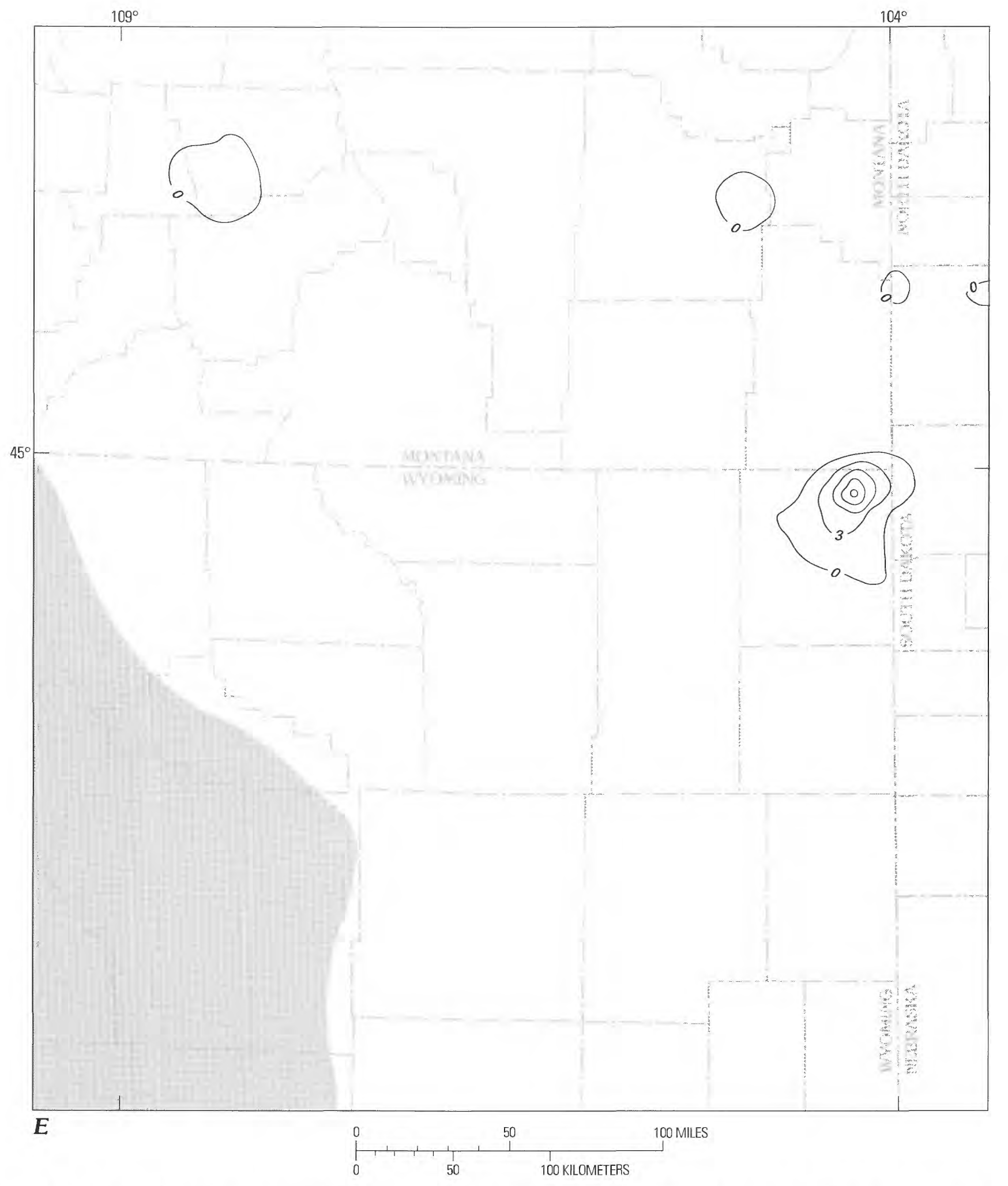

Figure 56 (continued). Lithology of M12-Mc interval of stratigraphic sequence four (Upper Mississippian, lower? Meramecian). $E$, Crinoidal carbonate (contour interval 3 percent). 


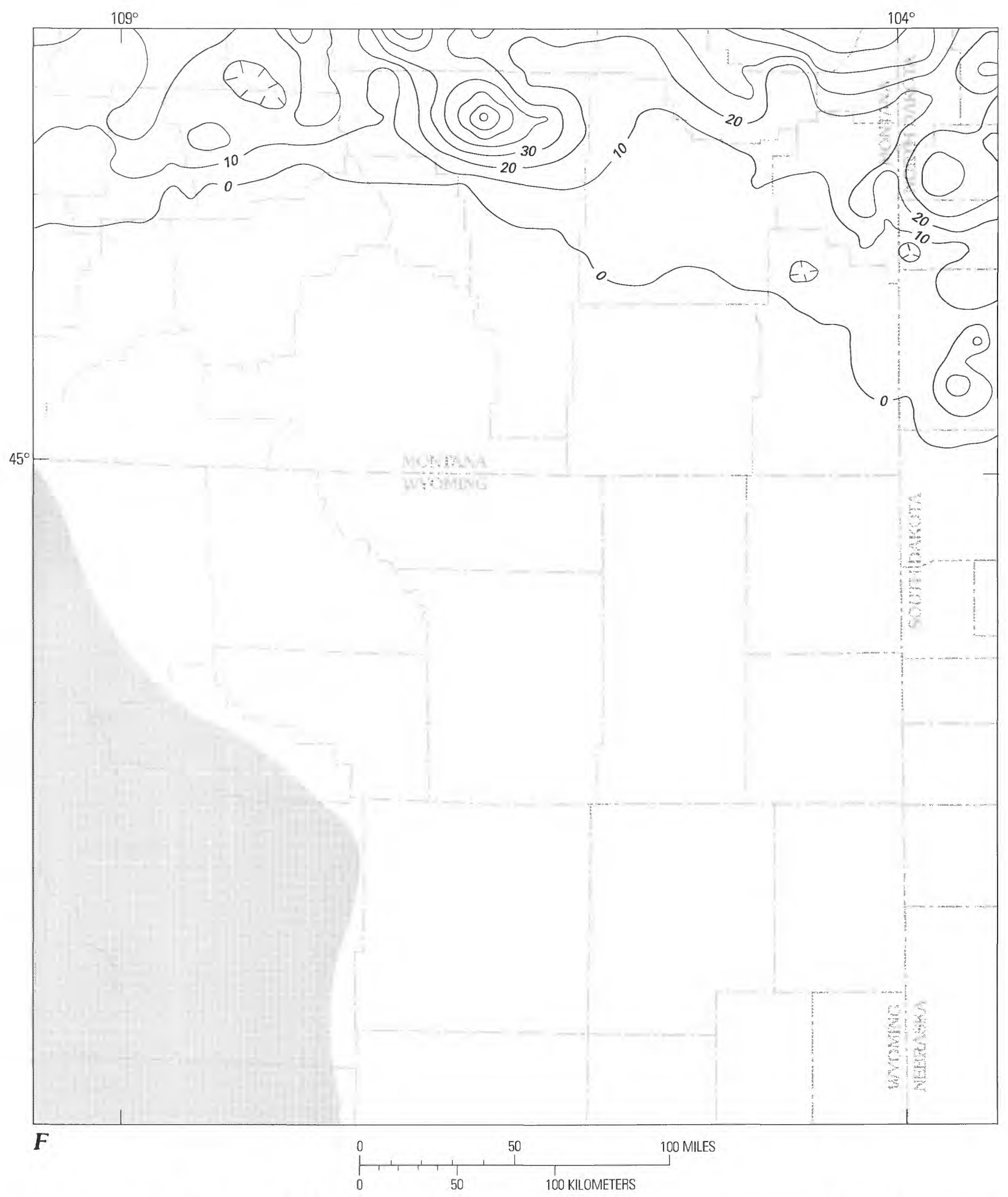

Figure 56 (continued). Lithology of M12-Mc interval of stratigraphic sequence four (Upper Mississippian, lower? Meramecian). $F$, Evaporite (contour interval 10 percent). 


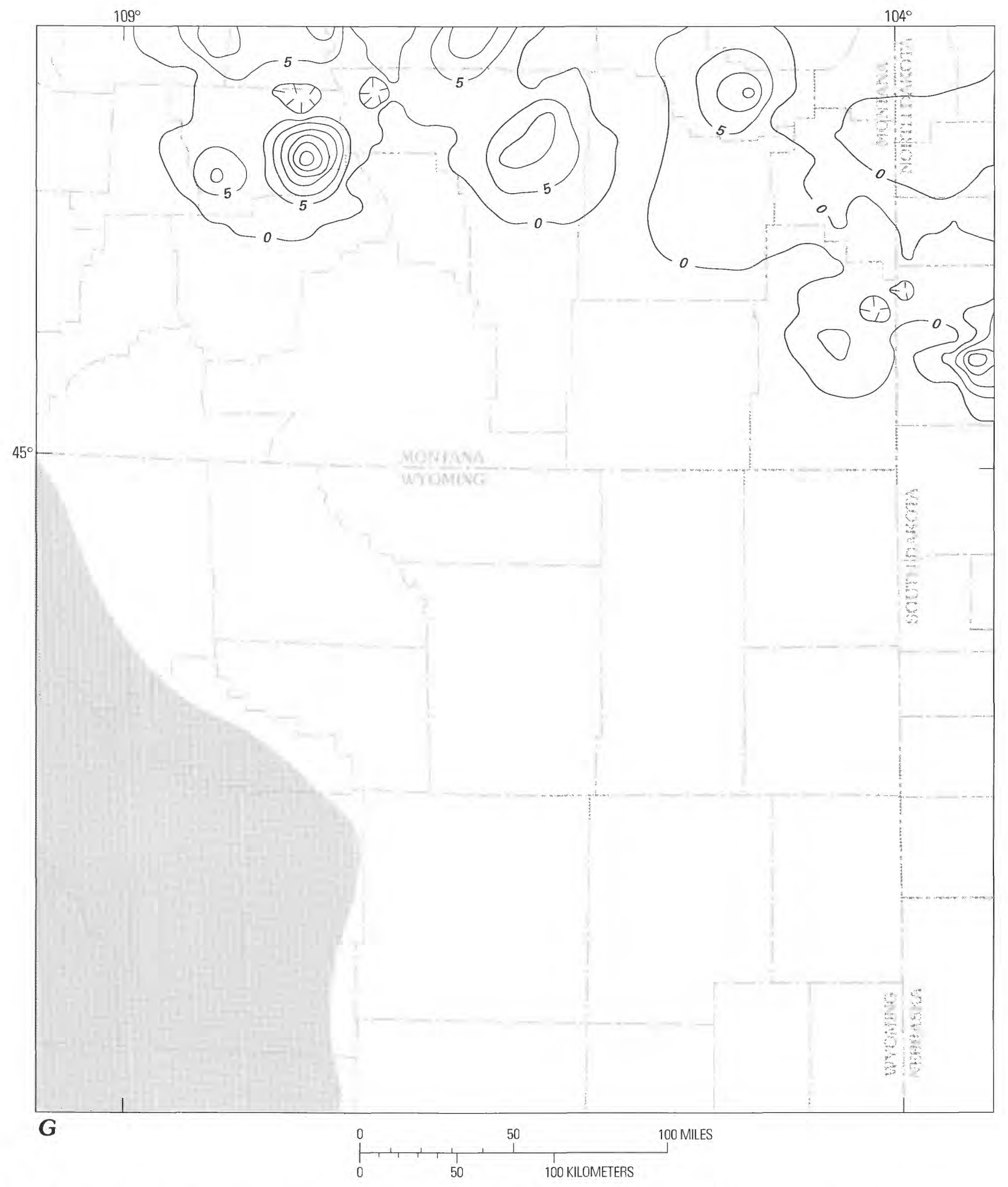

Figure 56 (continued). Lithology of M12-Mc interval of stratigraphic sequence four (Upper Mississippian, lower? Meramecian). $G$, Bioclastic carbonate (contour interval 5 percent). 


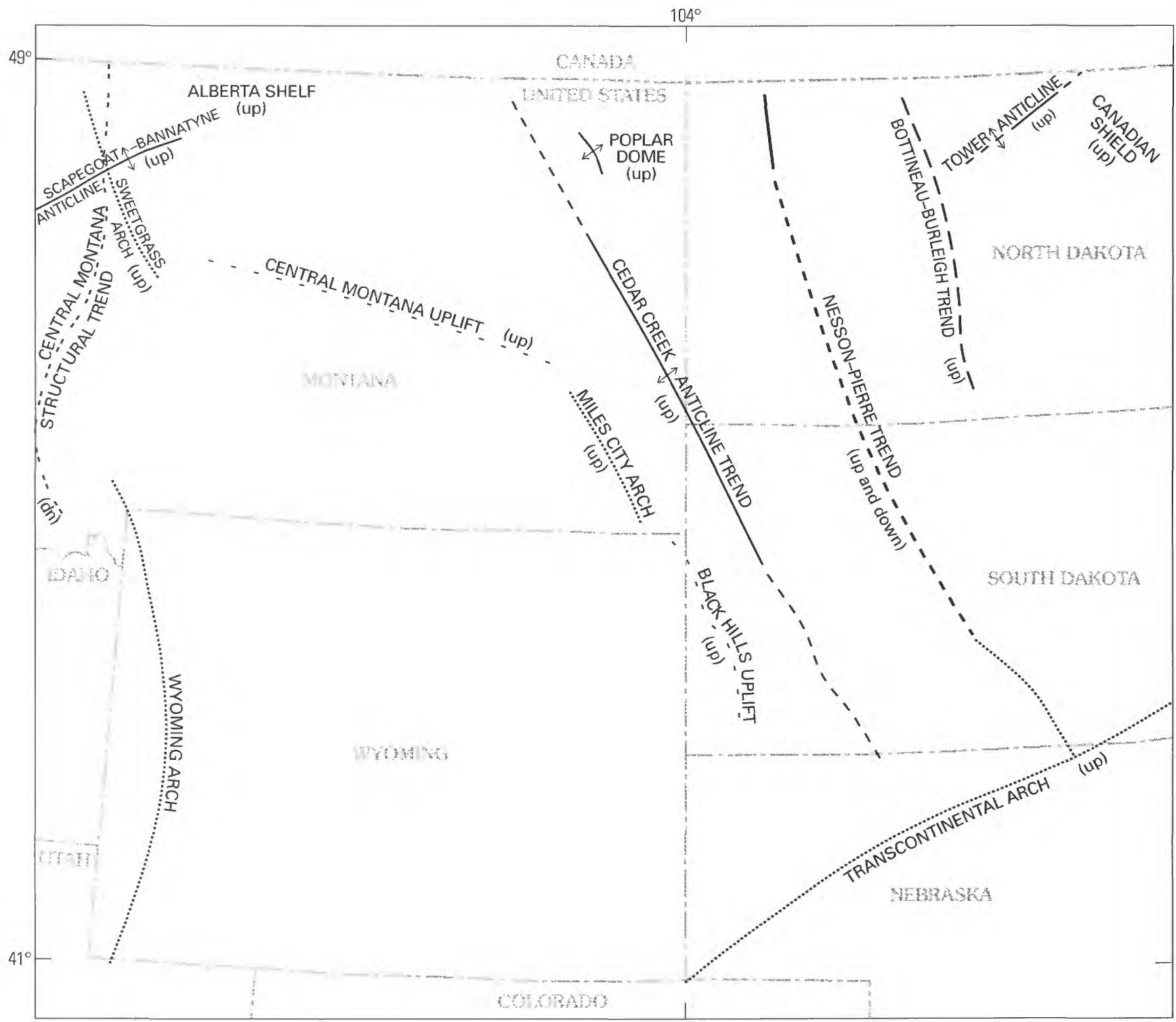

\section{EXPLANATION}
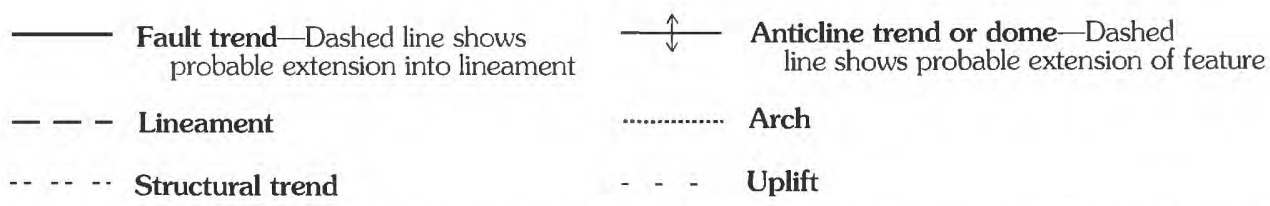

Figure 57. Paleostructural trends of stratigraphic sequence three (Middle and Upper Devonian) in the northern Great Plains. From Brown and others (1984).

or pre-Middle Jurassic erosion. The change in the pre-M8.5 section from predominantly dolomite in the Central Montana trough to primarily crinoidal limestone and silty, shaly limestone in central Montana suggests that structural elements influenced dolomitization and crinoidal buildups (Brown and others, 1984) (figs. 48, 50, 52).
Along the Cedar Creek anticline (figs. 1, 58), the Madison Group is thin and contains increasingly smaller crinoidal and oolitic mounds upward in the Lodgepole Limestone. This area is roughly coincident with thinning of the Devonian section, consistent with continued upward movement of the anticline from Devonian into Early 


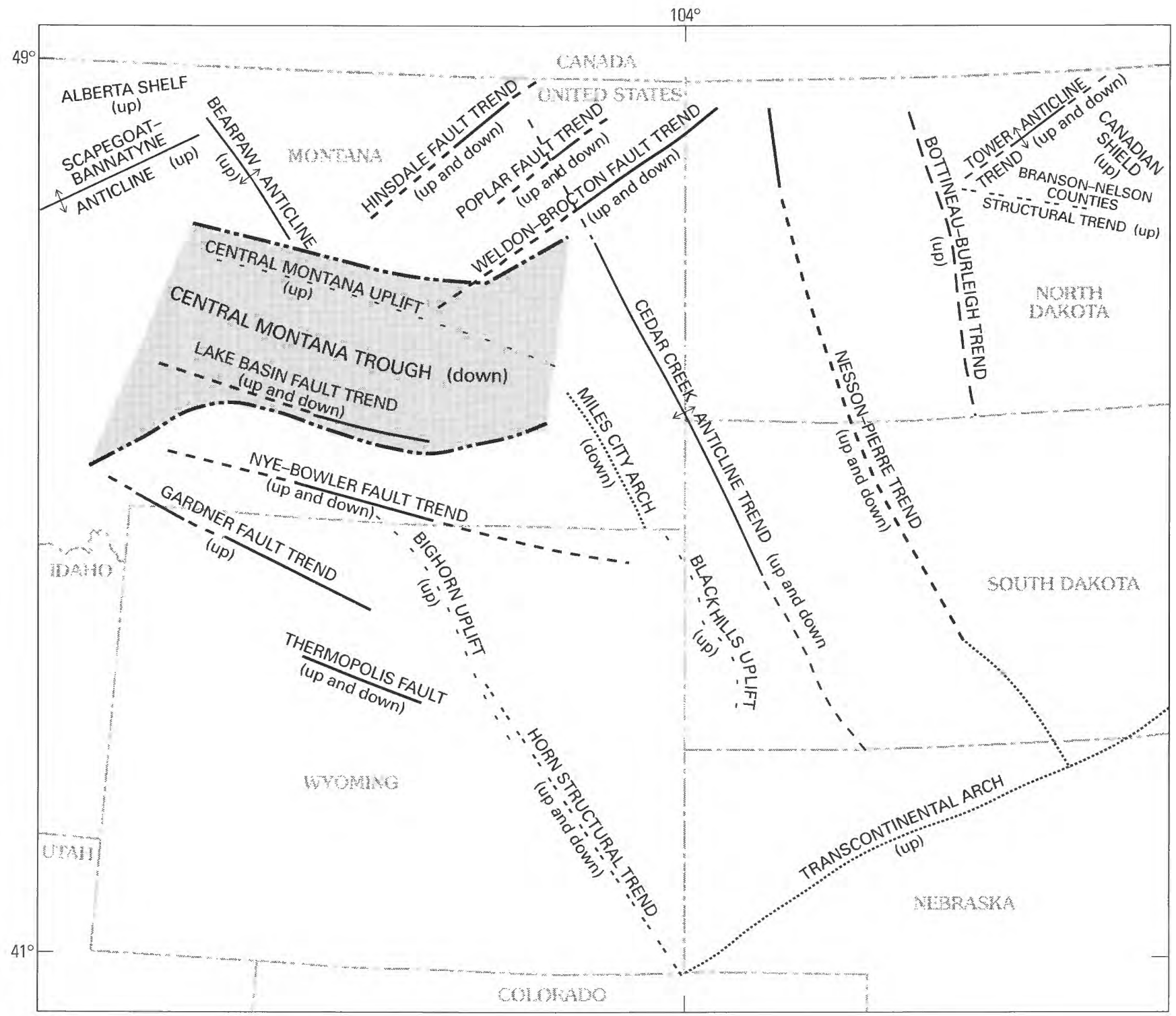

A

EXPLANATION

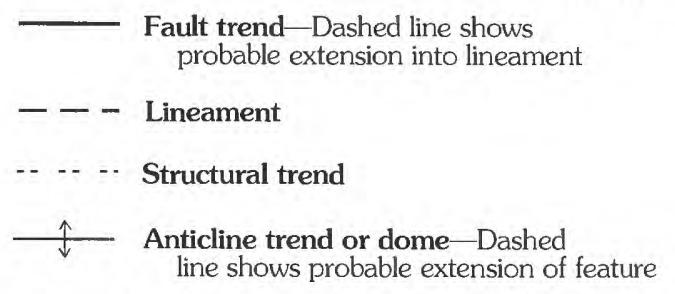

Figure 58. Paleostructural trends of stratigraphic sequence four (older Mississippian) in the northern Great Plains. Modified from Brown and others (1984). A, Kinderhookian.

Mississippian time. The Central Montana trough, in contrast, has a thick Devonian section and a thin Mississippian section, consistent with a reversal of movement from Devonian to Mississippian time.

In the Black Hills area of the Powder River Basin, Lower Mississippian sedimentary rocks vary considerably in thickness; the age of the upper part of these rocks probably varies from place to place because of either pre-Pennsylvanian erosion (Randal, 1963) or extensive sabkha development in latest Mississippian or earliest Pennsylvanian time during the first stages of the ancestral Rocky Mountain uplift (Maughan, 1983). 


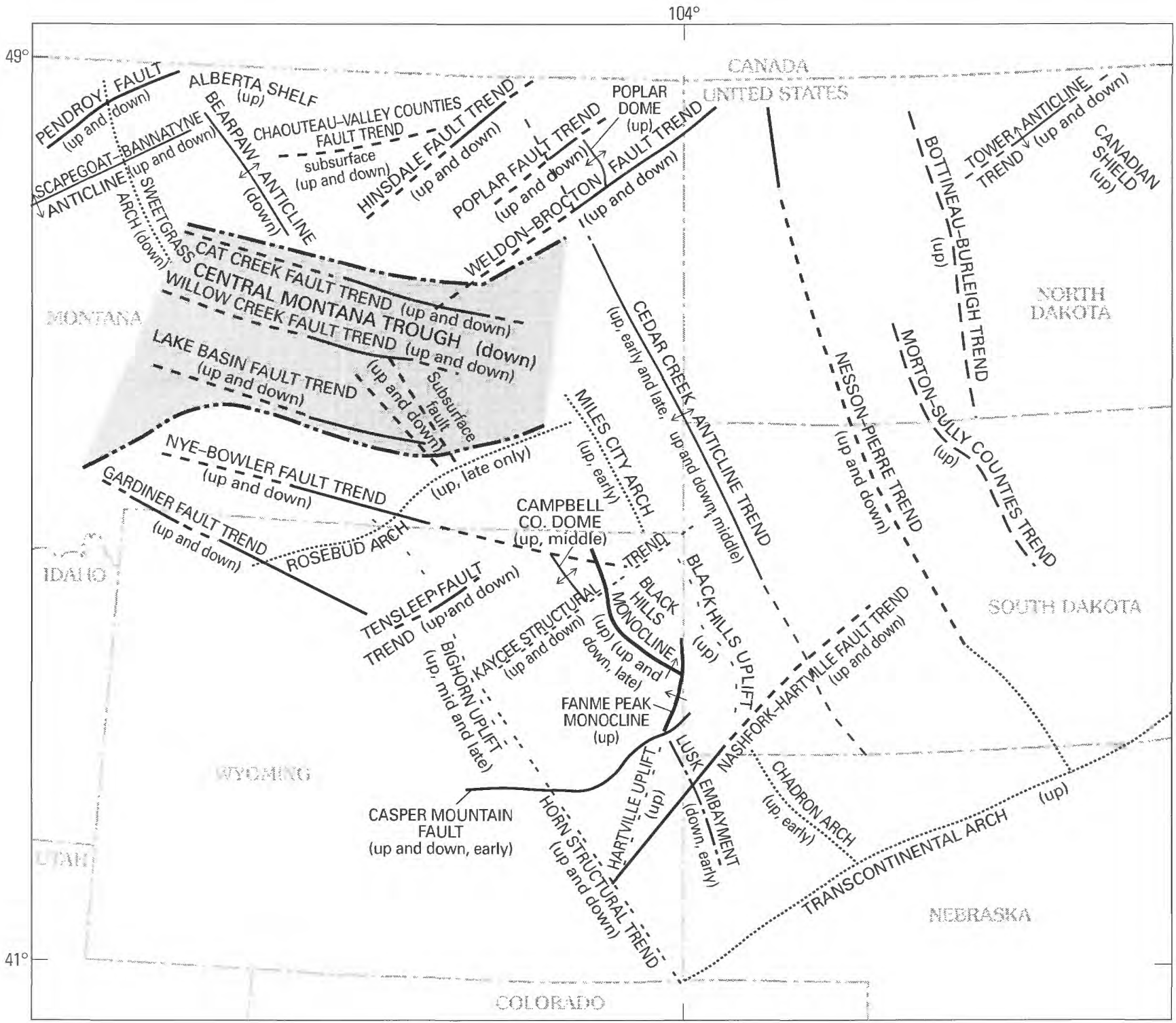

B

\section{EXPLANATION}
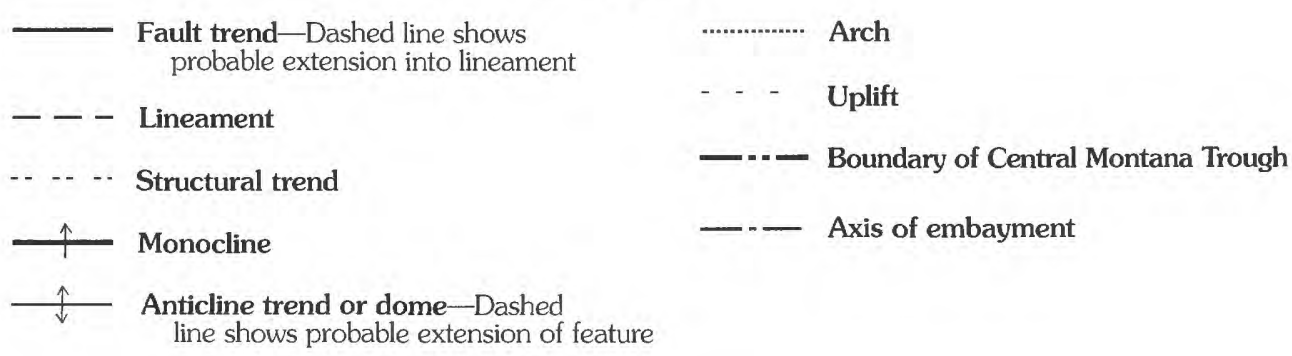

- Axis of embayment

Figure 58 (continued). Paleostructural trends of stratigraphic sequence four (older Mississippian) in the northern Great Plains. $B$, Osagean.

\section{Stratigraphic Units of Sequence Five}

The fifth stratigraphic sequence comprises the Big Snowy Group, consisting of (in ascending order) the Kibbey, Otter, and Heath Formations and equivalents
(Maughan and Roberts, 1967) of late Meramecian and Chesterian age (Sando and others, 1985) (figs. 2, 25, 41, 59). Sequence five is generally conformable with sequence four, although local unconformities exist. The Big Snowy Group is present only in the Williston Basin and the 


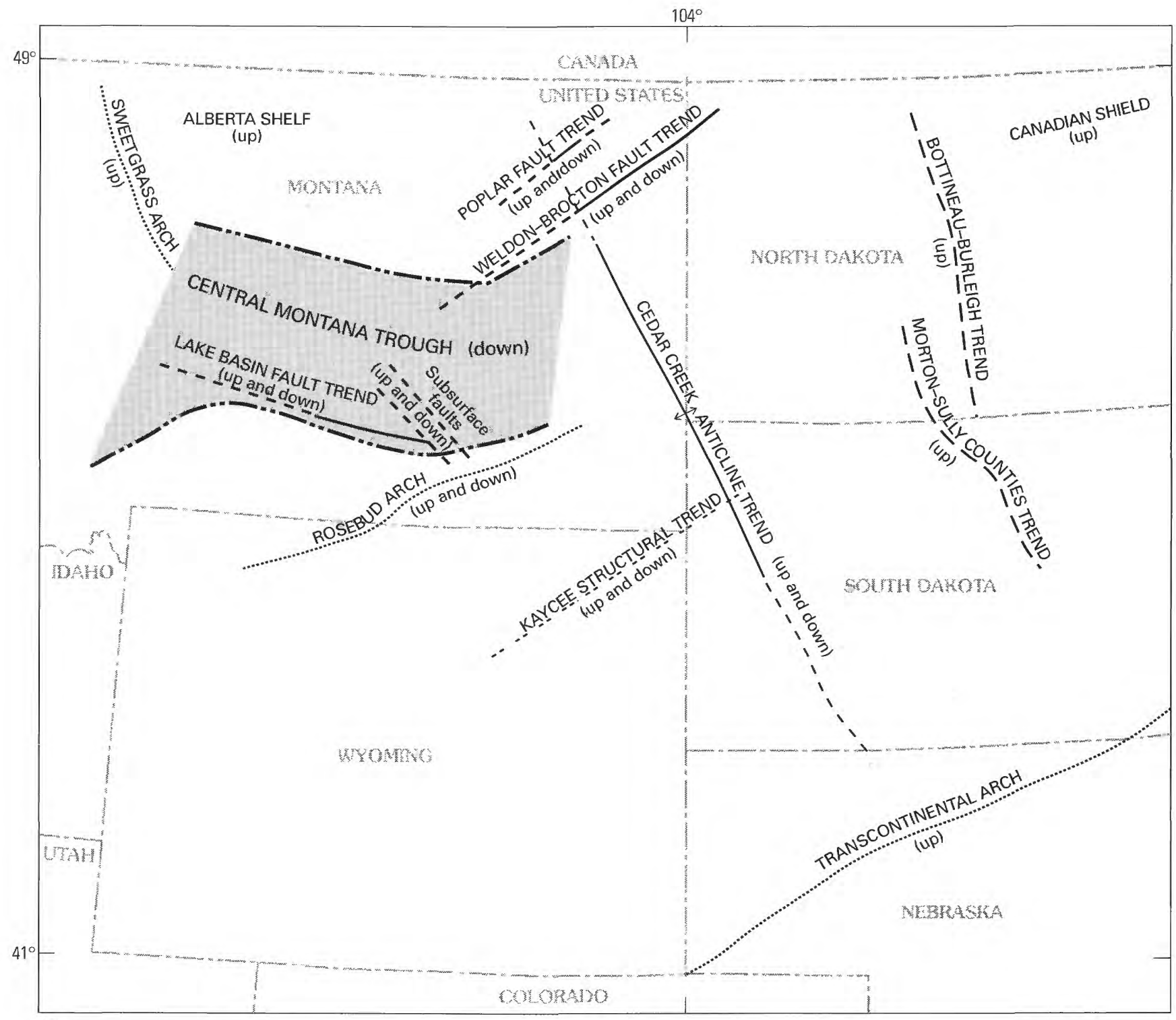

C

EXPLANATION

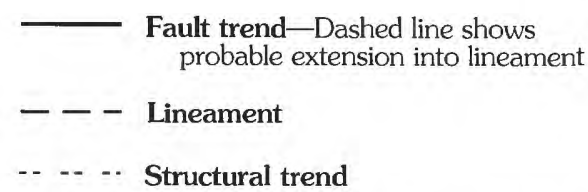

- - Boundary of Central Montana Trough

Arch

Figure 58 (continued). Paleostructural trends of stratigraphic sequence four (older Mississippian) in the northern Great Plains. $C$, Meramecian.

Central Montana (Big Snowy) trough (Roberts, 1979) (figs. 1, 60). The Big Snowy Group is composed predominantly of terrigenous clastic rocks and minor carbonate rocks and is as thick as $1,000 \mathrm{ft}(305 \mathrm{~m})$ or more in the Big Snowy trough north of the basin and $600 \mathrm{ft}(183 \mathrm{~m})$ or more in the eastern Montana and western North Dakota parts of the Williston Basin (Peterson, 1984). Late
Mississippian, Early Pennsylvanian, and early Mesozoic erosion removed the Big Snowy Group in north- and south-central Montana and around the Williston Basin (Peterson, 1984).

In the Powder River Basin, the uppermost Mississippian unit, the Darwin Sandstone Member, was deposited following a marine regression in the middle to late Meramecian 


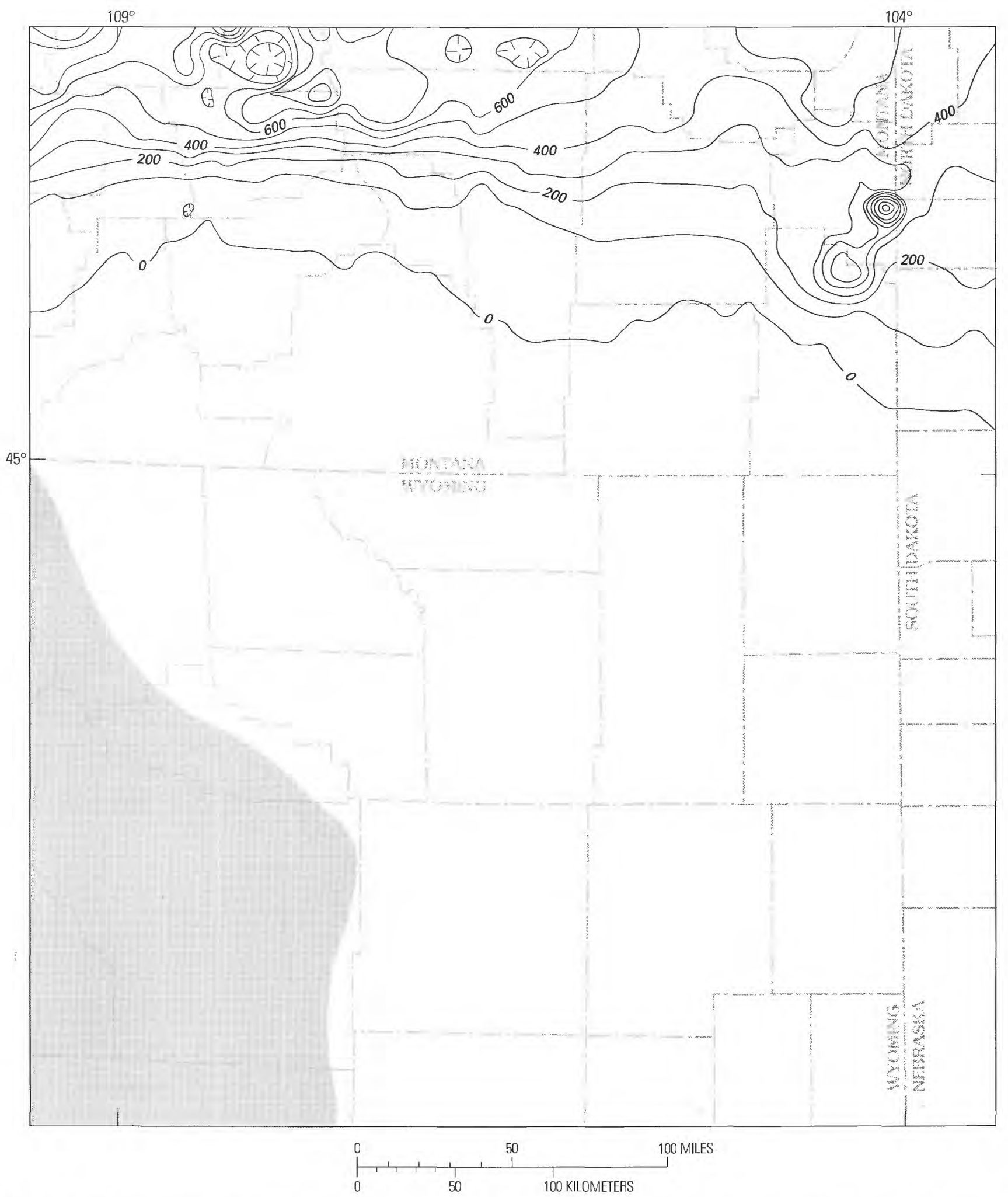

Figure 59. Isopach map of Big Snowy Group and equivalent rocks (younger Mississippian, upper Meramecian and Chesterian) of stratigraphic sequence five. Contour interval $100 \mathrm{ft}(30.1 \mathrm{~m})$. Based on 496 wells; gridded on an approximately $7 \mathrm{mi}$ by 7 mi grid $(12 \mathrm{~km}$ by $12 \mathrm{~km})$. Screened area in southwestern part of map area is an area of very limited control. Data modified from Downey (1982). Map area shown in figure 3. 


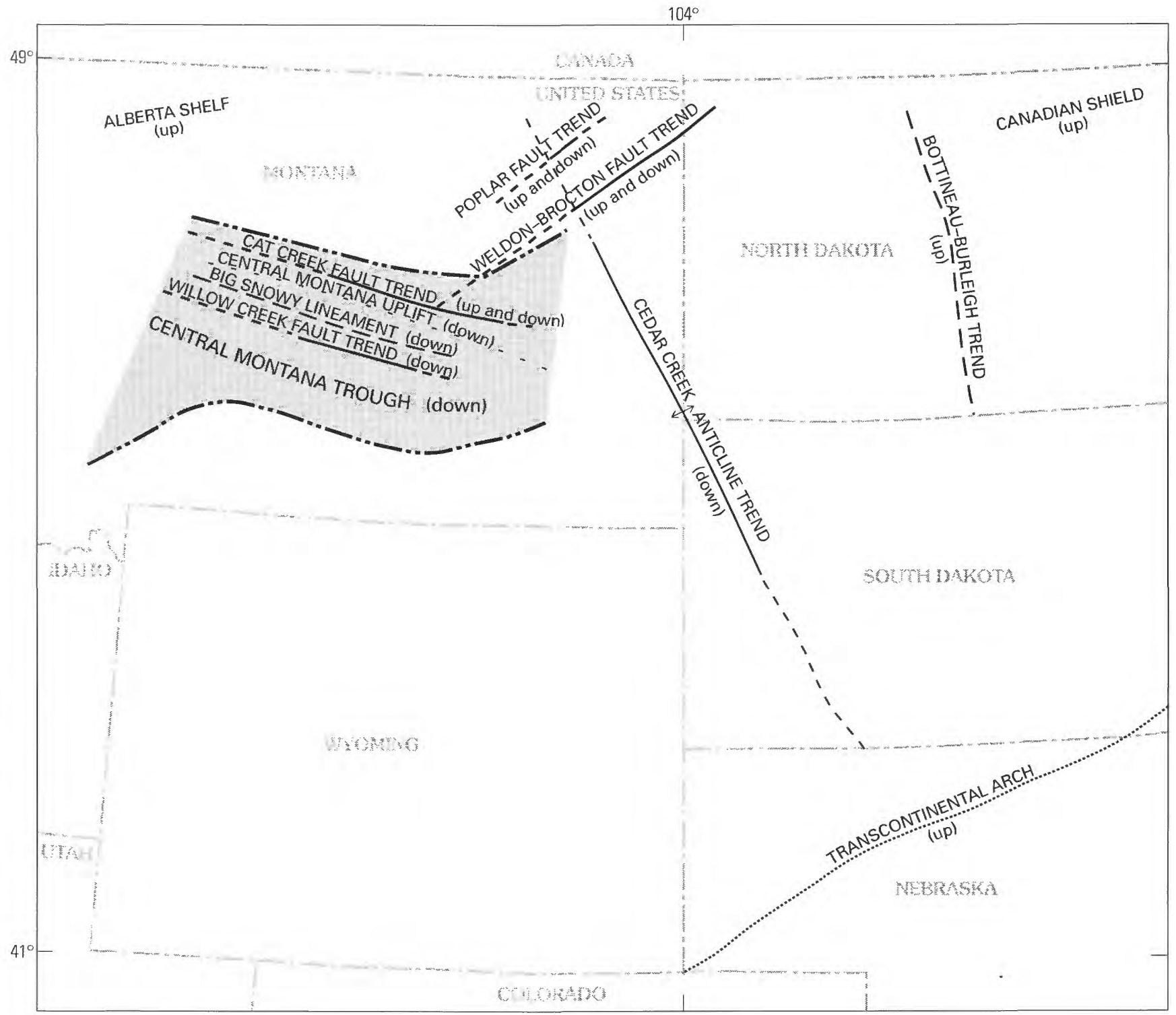

\section{EXPLANATION}
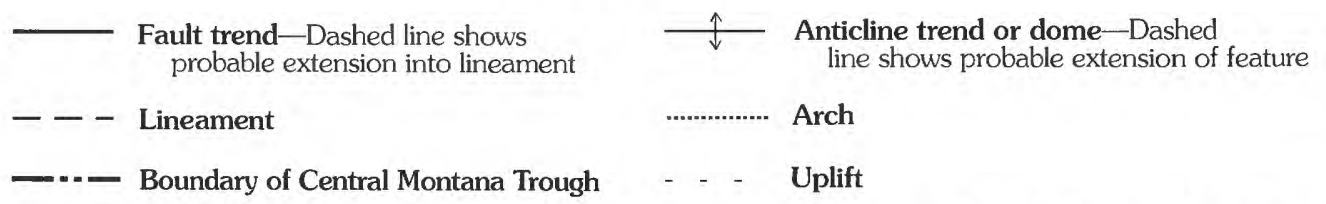

Figure 60. Paleostructural trends of stratigraphic sequence five (younger Mississippian) in the northern Great Plains. Modified from Brown and others (1984).

(Late Mississippian). The Darwin Sandstone Member is conformable on carbonate rocks of the Madison Limestone (stratigraphic relationships of the Madison and Darwin are being reviewed and summarized by Maughan, written commun., 1991). To the north, in the Central Montana trough part of the Williston Basin, deposition of the upper Meramecian and Chesterian Big Snowy Group followed the middle Meramecian regression. The top of the Mississippian System in the Powder River Basin, however, is generally Meramecian in age except where erosion has exposed older rocks beneath the overlying unconformity. The ancestral Rocky Mountain epeirorogeny in latest Mississippian or Early Pennsylvanian time brought early Paleozoic sedimentation on the Wyoming shelf to an end. This 
deformation was probably expressed as block faulting associated with the Ouachita orogeny. Widespread terra rossa on the Madison Limestone reflects late Chesterian (Late Mississippian) to early Morrowan (Early Pennsylvanian) karsting and erosion. In the Powder River Basin area, the terra rossa was reworked and redeposited as the Horseshoe Shale Member of the Amsden Formation (upper Morrowan) during Early Pennsylvanian transgression.

Scott (1935), Sloss (1952), Mundt (1956), Gardner (1959), Willis (1959), Maughan and Roberts (1967), Maughan (1984), Peterson (1984), and Peterson and MacCary (1987) summarized stratigraphy of the Big Snowy Group.

\section{Kibbey Formation}

The Kibbey Formation (fig. 35), at the base of the Big Snowy Group, consists of 200-300 ft $(61-91 \mathrm{~m})$ of red shale, siltstone, sandstone, and limestone deposited primarily in a nearshore-marine environment. An upward increase in the amount of sandstone in the section to the north and east in the Williston Basin shows clastic source areas in that direction. The "Kibbey lime" of informal subsurface usage is a widespread, thin carbonate marker roughly in the middle of the formation in the Williston Basin and Central Montana trough (Peterson, 1984). Peterson (1984) considered the Kibbey to overlie the Charles Formation (Osagean and Meramecian) disconformably in most places, except for parts of the central Williston Basin and the center of the Central Montana trough. Meramecian foraminifera from the limestone of the Kibbey, however, show that the Meramecian-Chesterian boundary is above the base of the Kibbey (E.K. Maughan, written commun., 1991) and that the break between Charles and Kibbey deposition must be minor.

\section{Otter Formation}

The Otter Formation (fig. 35) conformably overlies the Kibbey Formation and consists of 200-300 ft (61-91 m) of nearshore-marine, tidal-flat beds of green shale and minor finely crystalline, generally stromatolitic, nonporous limestone or dolomite (Peterson, 1984).

\section{Heath Formation}

The Heath Formation (fig. 35), the upper member of the Big Snowy Group in the interior of the Central Montana trough and the western part of the Williston Basin, consists of $200-400 \mathrm{ft}(61-122 \mathrm{~m})$ of dark-gray to black, highly organic nearshore-marine shale, limestone, and minor siltstone or fine-grained sandstone, primarily of restricted-marine(?) origin. Early Pennsylvanian erosion locally removed the Heath, especially within the Central Montana trough (Peterson, 1984).

\section{Darwin Sandstone Member of the Amsden Formation}

Along the flanks of the Bighorn Mountains the Darwin Sandstone Member of the Amsden Formation represents stratigraphic sequence five (figs. 2, 35). Although the Darwin is not shown on the cross sections (pls. 1, 2), it establishes the minimum age of the top of sequence four throughout the Powder River Basin area. I consider the Darwin to rest conformably on the Madison Limestone, and its Meramecian and Chesterian age is shown by correlation (1) northward into the Meramecian and Chesterian Kibbey Sandstone in the lower part of the Upper Mississippian Big Snowy Group in eastern Montana (Maughan and Roberts, 1967; Lageson and others, 1979, fig. 12); (2) southward into the Upper Mississippian (Meramecian) Humbug Formation in northern Utah (Maughan, in Lageson and others, 1979); and (3) westward from the type area of the Darwin into strata beneath the Meramecian and Chesterian Monroe Canyon Limestone in southeastern Idaho and into the Upper Mississippian (middle Meramecian) Little Flat Formation farther to the west in eastern Idaho (Sando, 1967, fig. 3).

The Darwin represents progradation of continentalmargin silicate detrital facies over carbonate coastalsabkha environments of tidal-flat deposits of the Mission Canyon (fig. 40). At Amsden Creek, the Darwin is unconformable beneath the overlying Horseshoe Shale Member of the Amsden Formation (Mallory, 1967), which represents a renewed transgression. The Darwin represents a period of increased detrital input that caused a shift in the carbonate-silicate interface from the high-tide line to the shallow subtidal zone (Houlick, 1973).

The upper part of the Darwin may be Chesterian in age, but the conformable and locally transitional contact of the Darwin upon the Osagean and Meramecian Mission Canyon precludes any significant younging at the base of the formation. A regional unconformity between the Darwin and the Horseshoe Members of the Amsden Formation (fig. 35) prohibits correlation of the Darwin as a time-transgressive equivalent of Pennsylvanian strata in central Wyoming as suggested by Sando and Mamet (1974), Sando (1975, 1976b, 1978), and Sando and Sandberg (1987) (E.K. Maughan, 1989, written commun.). The middle Meramecian regression and progradation that preceded deposition of the Darwin corresponds to a major sea-level drop on the sea-level curves of Vail and others (1977) (E.K. Maughan, 1987, oral and written commun., 1989, 1991).

The base of the stratigraphic sequence overlying stratigraphic sequence five (figs. 2,61) varies in age around the basin area from as old as Morrowan to as young as Desmoinesian. In the Bighorn Mountains, the post-Mississippian sequence begins at the base of the upper part of the Amsden Formation (above the Darwin Sandstone Member), slightly older than the base of the Hartville Formation in the area of the Hartville uplift (fig. 1). In the 


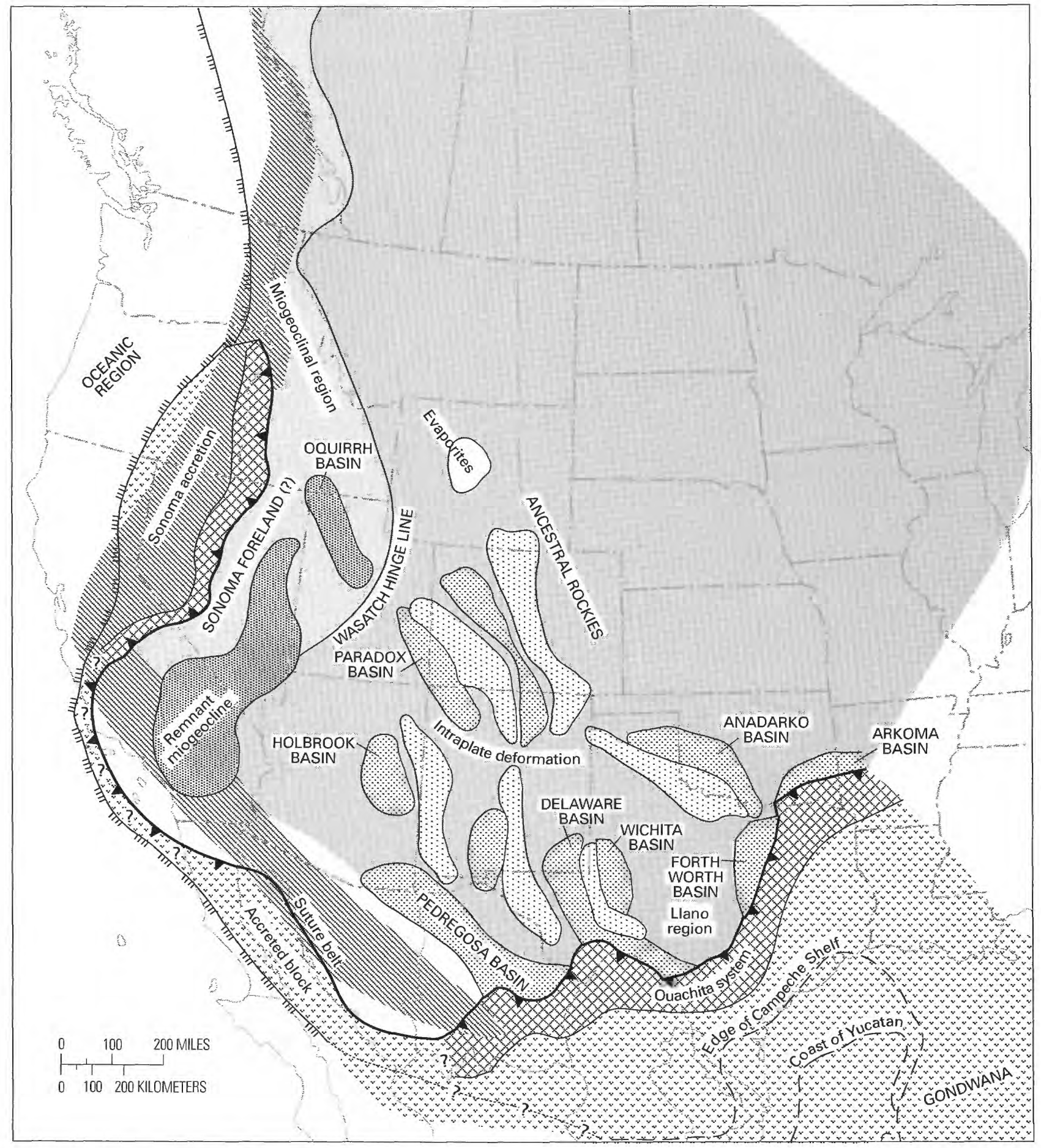

Figure 61. Paleogeography following close of stratigraphic sequence five (mid-Carboniferous to mid-Triassic). Shading (dark) shows areas of thin sediments and periodic low-relief uplift; wide-spaced dotted pattern shows areas of block-faulted uplifts; diagonal rules show allocthonous, post-Paleozoic continent; shading (light) indicates area of Mesozoic compression and Tertiary extension where geometric relationships are uncertain; stippling shows location of clastic basin; $v$ pattern shows block accreted during this interval (many of these blocks have been removed by later rifting); crossrules show areas of thrust-related marginal uplifts; dashed lines with barbs show inferred continental margin; toothed lines show major thrust-fault boundaries. Modified from Dickinson (1981) and others. 
Black Hills, the base of the interval is the Minnelusa Formation of Early Pennsylvanian age. In the Laramie Range, the base is the younger Casper Formation of Middle Pennsylvanian to Early Permian age. In the central and northern Bighorn Mountains, the Amsden Formation conformably underlies the eolian Tensleep Sandstone, which represents the large dune fields that developed in central and western Wyoming (Mallory, 1972). The Minnelusa, Casper, and Hartville Formations are interfingering eolian, continental, and marine deposits developed along the northern edge of the ancestral Rocky Mountain uplift (Mallory, 1972). The Minnelusa Formation in the eastern Powder River Basin varies considerably in rock type and thickness and represents a mixture of eolian coastal-dune complexes and marine carbonate and evaporite rocks of marginal-marine and sabkha origin. Pennsylvanian and Permian rocks overlying stratigraphic sequence five are being studied by E.K. Maughan as part of the Evolution of Sedimentary Basins Program and will not be discussed at length here.

\section{POROSITY TRENDS AND PETROLEUM GEOLOGY}

Twenty-four of the fifty-three wells used to construct the cross sections shown on plates 1 and 2 contain oil shows within the lower Paleozoic section that range in character from dead oil to positive tests for petroleum. The left margins of the $\operatorname{logs}$ shown on plates 1 and 2 depict data on oil shows from published AMSTRAT logs.

Four areas of high porosity are in the Bighorn Dolomite within the Powder River Basin (fig. 62). The first area is in Crook County, Wyoming, and Carter County, Montana, astride the southern extension of the Miles City arch (fig. 18). The second area is in Sheridan County, Wyoming, and Big Horn County, Montana, atop the NyeBowler fault zone, southeast of the intersection of the trends of the Rosebud arch and Bighorn uplift. The third area is coincident with the Rosebud arch northwest of the second area and extends northeastward into the fourth area, in northern Big Horn and Treasure Counties, Montana. The fourth area is coincident with an unnamed structural trend (Brown and others, 1984) extending from Powder River through Rosebud Counties, Montana, parallel with the Bighorn uplift trend to the southwest and the Miles City arch trend to the east. Areas of high porosity also are present (fig. 62) in the Big Snowy trough and in the western Williston Basin to the north of the Powder River Basin.

Jennings (1987) identified an "economic fairway" for petroleum in the Red River Formation of the western Williston Basin that could project southward into the northern Powder River Basin. Although the Winnipeg
Group throughout the Williston Basin has served as a hydrocarbon source (fig. 63), the main areas of high organic carbon capable of generating large quantities of oil are in the Minot, North Dakota, area on the northeastern flank of the basin and in eastern Montana on the western flank of the basin. Much of the oil in the Cedar Creek anticline apparently was derived from the Winnipeg source in eastern Montana. Winnipeg-derived oil from Ordovician reservoirs is apparently limited to traps having evaporite seals, and Winnipeg-derived oils from postOrdovician reservoirs may have migrated along fracture pathways associated with structure. No Winnipeg-derived oil has been identified southeast of the Cedar Creek anticline (Dow, 1974).

According to Meissner and others (1984), uppermost Devonian through middle Mississippian source rocks include the Bakken Formation in the Williston Basin, the Exshaw Formation of northwestern Montana, the Cottonwood Canyon Member of the Madison Formation in western Wyoming and adjacent areas, the Sappington Member of the Three Forks Formation in southwestern Wyoming and adjacent areas of Idaho, and the Leatham Formation of southwestern Wyoming and northeastern Utah. The Powder River Basin area was isolated from most petroleum source rocks of this age in the region by the Transcontinental arch. Possible exceptions are the Chainman Shale of the eastern Great Basin, the Madison Limestone equivalents in Utah, and the Pilot Shale of southern Utah and adjacent areas.

The best porosity in the Madison is along the eastern flank of the Williston Basin; other areas of good porosity include the Cedar Creek anticline and the Bighorn-Pryor Mountains trend (Brown and others, 1984) (figs. 64, 65). Except for the Cedar Creek anticline area, porosity decreases toward the central Williston Basin area as limestone increases in abundance. Dolomite generally has the highest porosity along the flank of the Williston Basin. Porosity is highest where the amounts of limestone and dolomite are about equal because a larger portion of coarsely crystalline secondary dolomite is present in these sections. Individual Madison porosity units tend to consist of tabular, porous dolomite beds, from a few to more than $50 \mathrm{ft}(15 \mathrm{~m})$ in thickness, extending over many tens of square miles (Peterson, 1978, 1984). To the northwest, north and east of the Sweetgrass arch and north of the Little Belt Mountains (fig. 1), a broad area of relatively good porosity in coarse crystalline dolomite facies of the Sun River Member of the Castle Reef Dolomite is at the top of the Madison Group in an interval that may be partly equivalent to the anhydrite in the middle part of the Madison Limestone of south-central and southeastern Montana.

Mississippian Waulsortian mounds are dolomitized and have good porosity in places, especially in the southwestern and southern parts of the Central Montana trough.

Oolitic beds in the M1-M5 interval have low porosity except in South Dakota. Along the eastern flank of the 


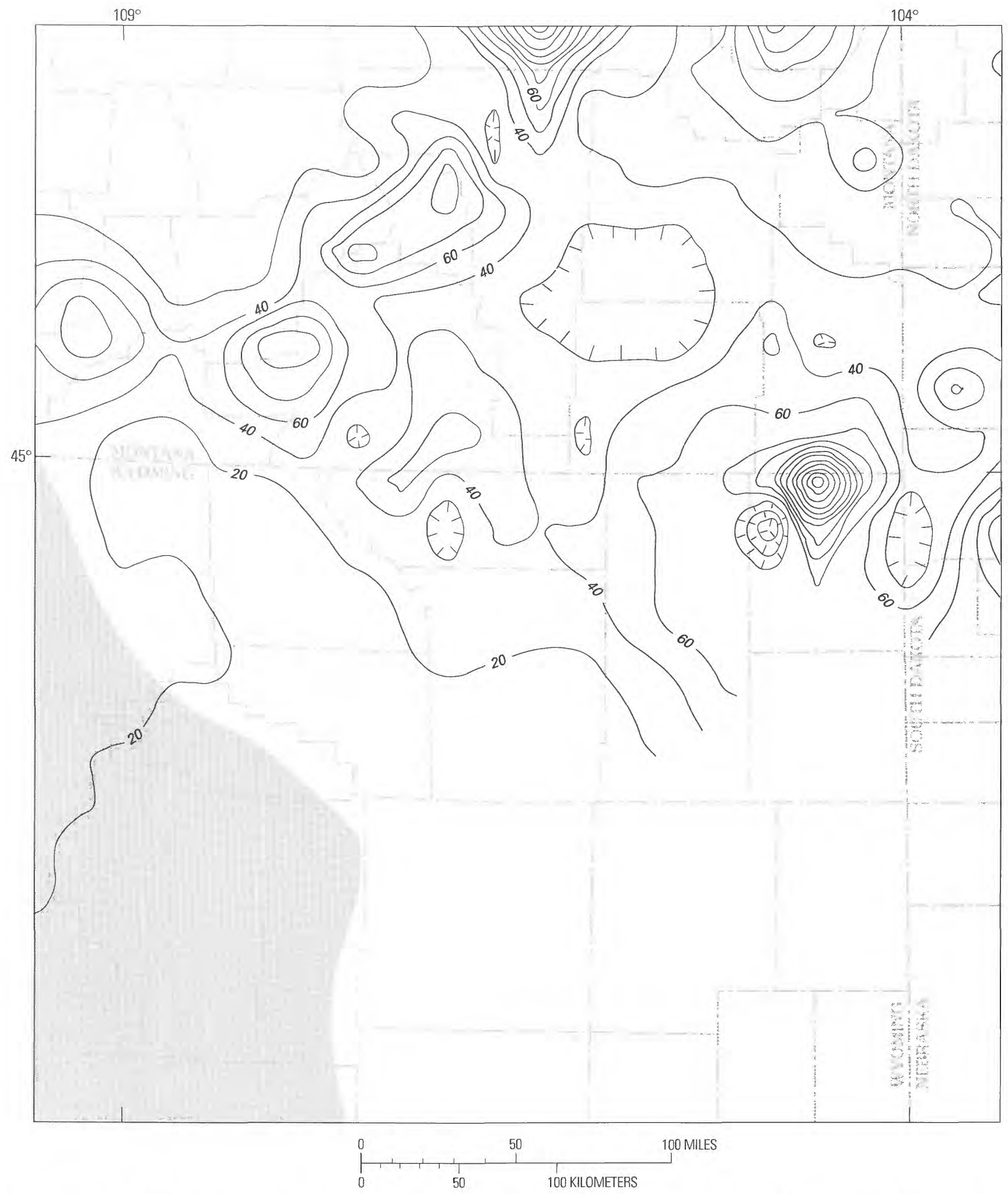

Figure 62. Feet of porosity greater than or equal to 10 percent in the Red River Formation-Bighorn Dolomite part of stratigraphic sequence two. Contour interval $20 \mathrm{ft}(6.1 \mathrm{~m})$. Based on 157 wells; gridded on an approximately $7 \mathrm{mi}$ by $7 \mathrm{mi}$ grid (12 km by 12 $\mathrm{km})$. Map area shown in figure 3. Data from Downey (1982). 
Williston Basin, dolomitization has produced significant porosity in crinoid mounds, which are about $250-300 \mathrm{ft}$ (76-91 m) thick except in the center of the basin where they are as thick as $400 \mathrm{ft}(122 \mathrm{~m})$. Maximum porcsity development has developed along the eastern and southern flanks of the Williston Basin (figs. 64, 65), along a northwesterly trend from the Bighorn Mountains and in places along the Cedar Creek anticline.

Porosity in the M3-M7 interval is highest in the dolomite, especially along the east flank of the Williston Basin in North Dakota (figs. 64, 65). Belts of significant porosity are along the northwest-trending Cedar Creek anticline and along the Bighorn-Pryor Mountains trend. Toward the interior of the Williston Basin, oolite beds generally are less porous and grade to predominantly low porosity oolitic limestone having a finely crystalline to dense limestone matrix (Peterson, 1984).

MacCary (1981) noted that some of the porosity of the M7-M8.5 interval coincides with the limestone facies along the west flank of the Williston Basin, along the northern border of North Dakota. The eastern porosity belt coincides with anhydrite trends but is in limestone, dolomite, and oolitic facies beneath the anhydrite. The best porosity is generally within the oolitic facies and in dolomitized limestone. Limestone along the flanks of the Williston Basin has some porosity, but porosity is poor in the center of the basin. Some halite is in the upper part of the evaporite interval in the central part of the basin. The anhydrite interval in the middle part of the Madison comprises the basal bed of the Charles Formation east of the Big Snowy Mountains (Seager, 1942). Porous facies in the M8.5-M12 interval generally are present as small isolated patches associated with oolitic or crinoidal mound buildups (figs. 64, 65). The M12-Mc interval generally has poor porosity except in a few places.

The oolitic facies is generally dolomitized and porosity is good at the top of the interval (middle part of the Madison). Bedded anhydrite as thick as $150 \mathrm{ft}(46 \mathrm{~m})$ is especially well developed in the Central Montana trough and in the southeastern Williston Basin (figs. 64, 65). Porosity is greatest in dolomite along the eastern and southern basin margins in North Dakota, northwestern South Dakota, northeastern Wyoming, and southeastern Montana and also along the Bighorn-Pryor Mountains trend and in the southeastern part of the Alberta shelf (MacCary, 1981; Peterson, 1984).

\section{CONCLUSIONS}

Lower Paleozoic rocks of the Wyoming shelf represent the remnants of three superimposed shelf-margin basins along the western continental margin of North America. The first shelf-margin basin developed in Cambrian to
Early Ordovician time. This basin was open to the west and was the site of deposition of shaly limestone, shale, and sandstone. The base of the Cambrian to Lower Ordovician stratigraphic sequence, the Flathead Sandstone, is a discontinuous sheet of transgressive sandstone deposited during successive shoreline progradation. Individual pulses of sedimentation within the Flathead were probably separated from succeeding pulses by pinchouts or shales updip to the east. The remainder of the sequence is a series of time-transgressive grand cycles, each consisting of a shaly half-cycle followed by a carbonate half-cycle. The top of each carbonate half-cycle is almost a time line and represents a rapid sea-level fall. The shale half-cycles represent renewed sea-level rise and drowning of the western carbonate rim of the basin. The carbonate half-cycles developed as sea level continued to rise and new carbonate rims developed such that terrigenous clastics were ponded near the cratonic margin of the basin and carbonate sedimentation spread out over the basin.

Middle Ordovician strata represent deposition in a large shelf-margin basin that was connected to the southern continental margin through the Nebraska sag and possibly through the Colorado extension of the Oklahoma Basin. The Wyoming arch, along the Wasatch hinge line, formed the western border of this basin. An area of Middle Ordovician subsidence along the Ouachita margin was separated from the subsiding Williston Basin by the relatively stable Transcontinental arch. Rocks of the Nebraska sag and diatremes near the Colorado-Wyoming State line preserve a record of sedimentation over the arch. The position of the Nebraska sag, and possibly the Williston Basin, probably was controlled by the Precambrian mobile belt separating the Wyoming shelf from the Superior province. Reworking of Winnipeg-equivalent sands at the base of the Bighorn Dolomite (the Harding Sandstone equivalent and Lander Sandstone Member) across the Wyoming arch (fig. 5) shows late transgression onto the arch. A breach in the Wyoming arch in the area of the Central Montana trough first connected the Williston Basin to the open ocean farther west. Downwarp of the Central Montana trough, filled with the thick Precambrian Belt Supergroup, suggests that the uplift of adjacent areas was isothermal, probably related to shortening in the upper lithosphere caused by subduction along the western cratonic margin. Ross (1976) postulated a borderland to the east of the trench in Middle Ordovician time. I would interpret this borderland, if it did exist, as the result of subduction along the cratonic margin, although any record of subduction has been removed by later tectonic activity along the continental margin.

Rapid subsidence within the Ouachita trough and Williston Basin and onlap of Middle Ordovician sediments onto the Wyoming arch (fig. 5) suggest that the Bighorn Dolomite section of the Powder River Basin area represents primarily nearshore lithofacies and that the 


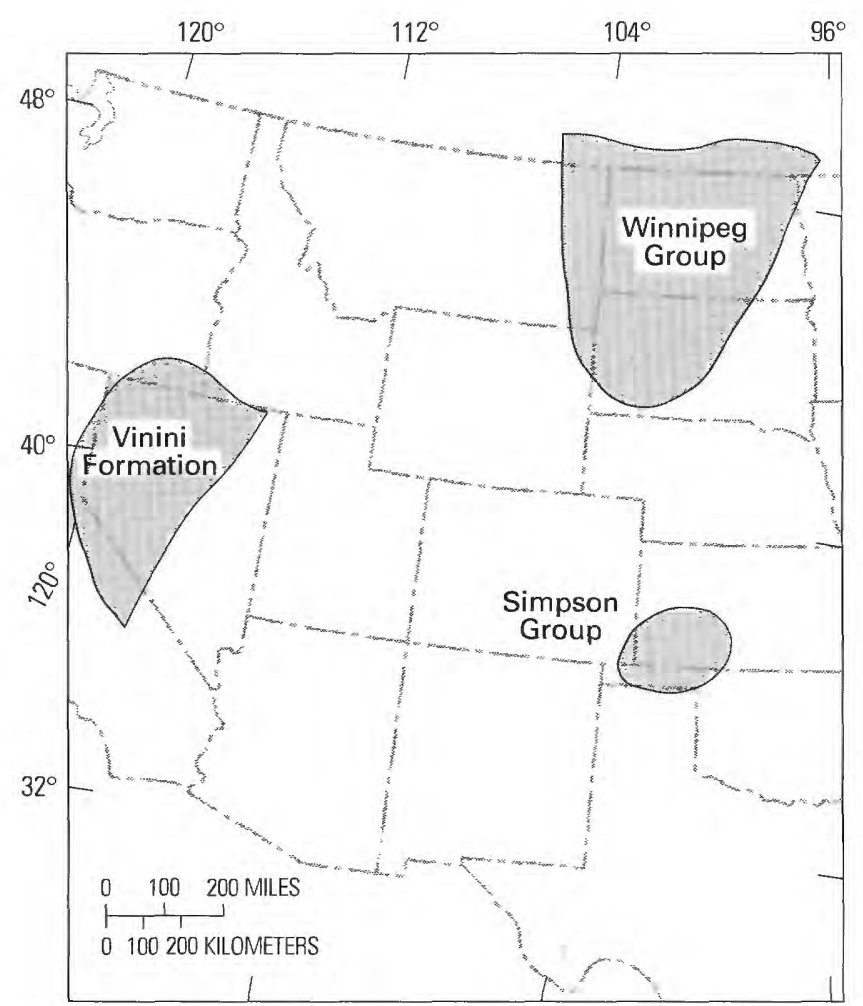

A

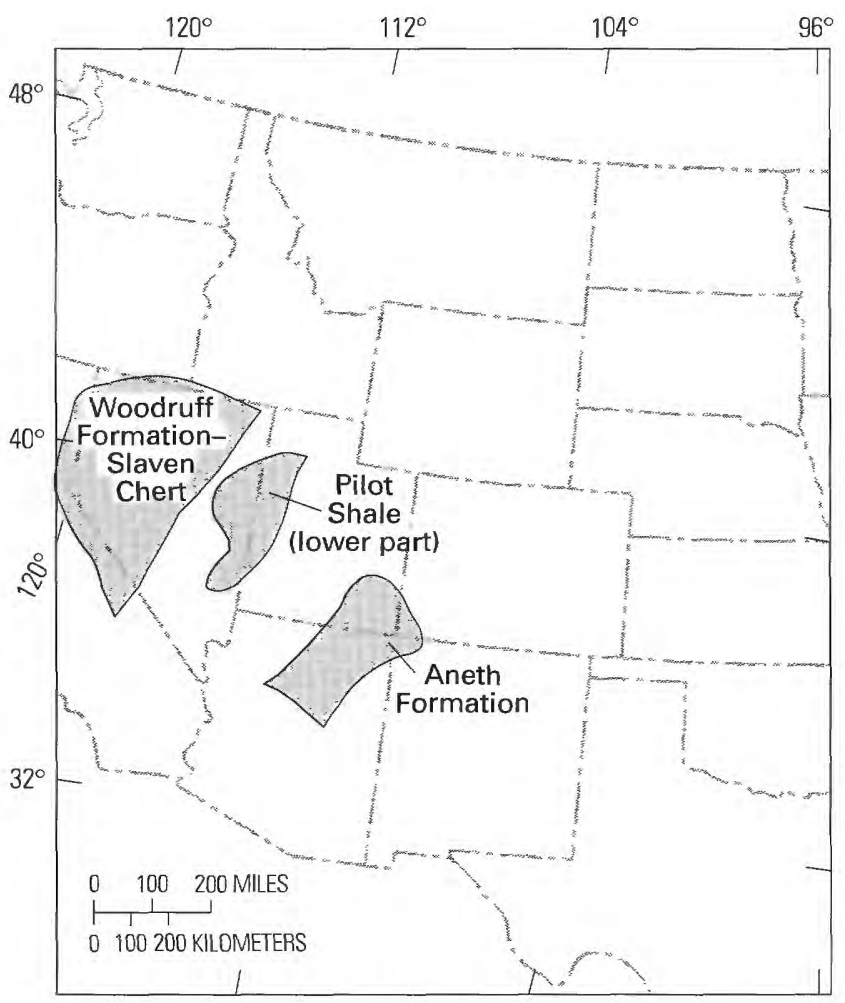

B

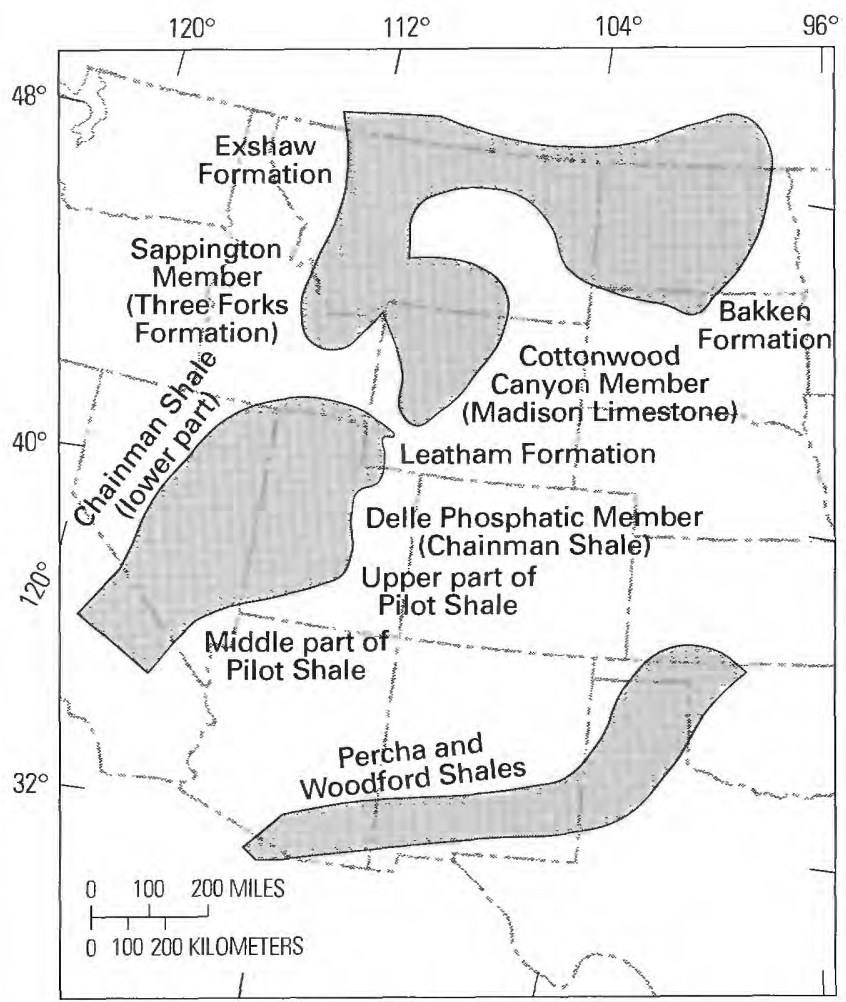

C

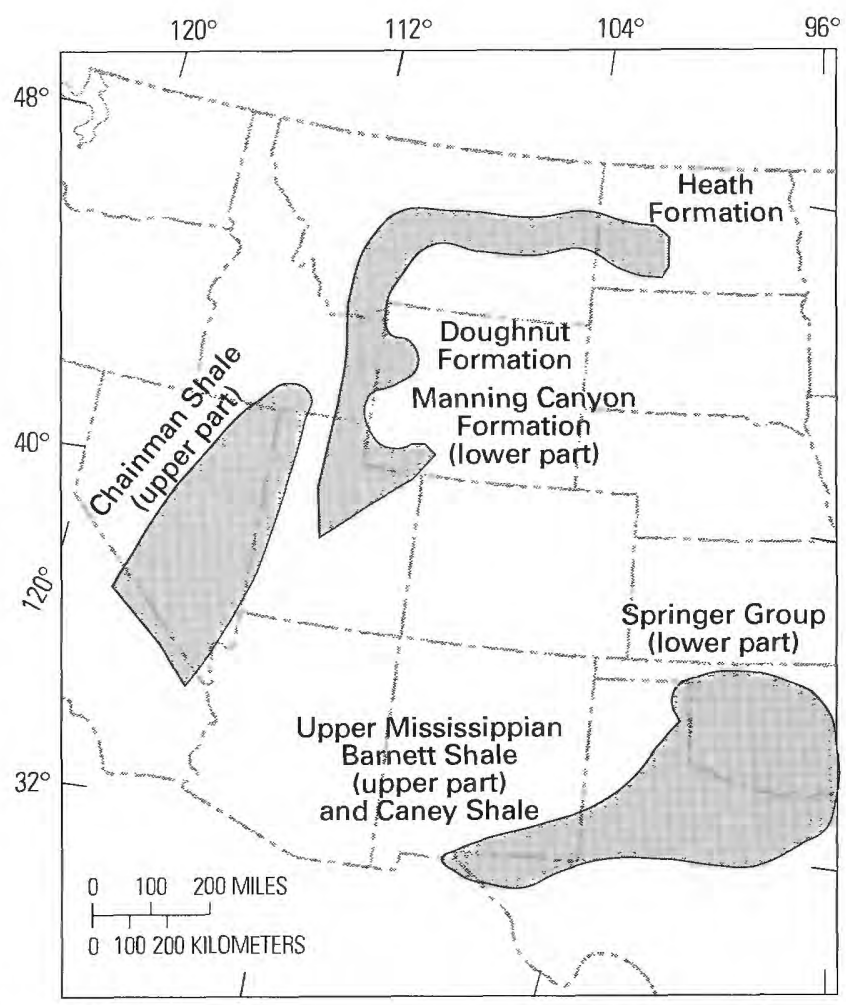

D

Figure 63. Petroleum source rocks in Rocky Mountain region. Modified from Meissner and others (1984). A, Ordovician. B, Devonian. C, Uppermost Devonian(?) through middle Mississippian. D, Upper Mississippian. E, Pennsylvanian. F, Permian and Triassic. 


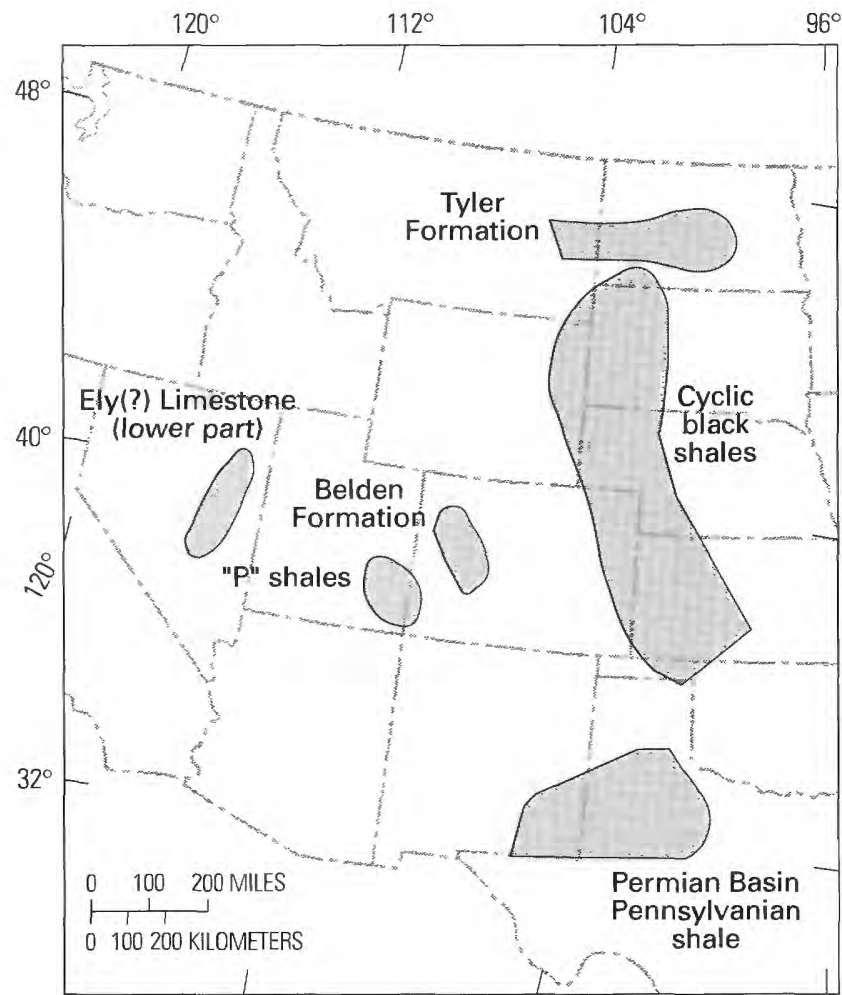

E

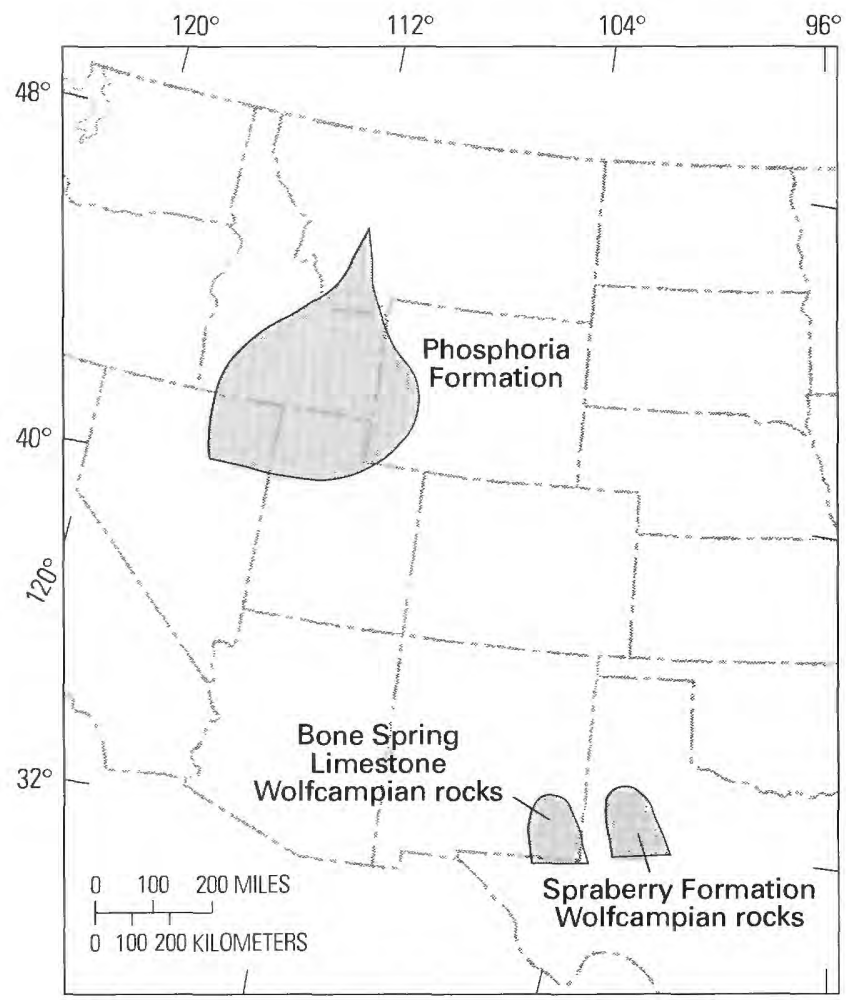

F

Ordovician section of the Powder River Basin was cut off from source rocks of the Vinini Formation to the west (Meissner and others, 1984) by the Wyoming arch.
Ordovician rocks in the Powder River Basin were also cut off from the Simpson Group source rocks (Meissner and others, 1984) in the Oklahoma Panhandle area by postOrdovician erosion.

Diatremes near the Wyoming-Colorado State line suggest that uplift of the Transcontinental arch followed deposition of the Middle Ordovician sequence and may have caused the erosion along the arch. Uplift may have been coincident with volcanism along the western margin of the craton (Irwin, 1977; Gray, 1986) and with the beginning of subduction along the Ouachita margin. A slowing of subsidence in the Ouachita trough in the Late Ordovician, Silurian, and Devonian (Morris, 1974) accompanied uplift of the Transcontinental arch. A Silurian arc terrane (Morris, 1974) along the Ouachita margin suggests that uplift of the area south of the Wyoming shelf was related to subduction similar to Middle Ordovician uplift of the Wyoming arch (fig. 5) to the west.

Middle Devonian time may mark a change from a subduction-dominated margin to a lateral-slip regime more closely related to subduction along the southern margin than to orogeny in the west. Devonian transgression was a mirror image of the Ordovician transgression. The Devonian transgression was primarily from north to south within a large shelf-margin basin open to the north. Early Devonian transgression began in Canada (lower part of the Elk Point Group) (Grayston and others, 1966), was separated from the miogeocline to the west by the Alberta arch, the northern extension of the Wyoming arch, and spread southward into the Williston Basin by Middle Devonian time (upper part of the Elk Point Group; Grayston and others, 1966) (figs. 1, 5).

In the present report, the Bakken Formation in the Williston Basin, the Exshaw Formation of northwestern Montana, the Cottonwood Canyon Member of the Madison Formation in western Wyoming and adjacent areas, the Sappington Member of the Three Forks Formation in southwestern Wyoming and adjacent areas of Idaho, and the Leatham Formation of southwestern Wyoming and northeastern Utah are considered to be stratigraphic equivalents.

At the end of Early Cambrian time, archaeocyathids became extinct, and blue-green algae became the primary carbonate-producing organisms in biogenic buildups. Cambrian mounds in the Cordilleran miogeocline in Utah and Nevada are massive micrite trapped by organisms rather than skeletal debris. During the Middle Cambrian to Early Ordovician, evolution of new carbonate-producing organisms created Lower Ordovician skeletal bioherms formed by dasycladacean algae, lithistid sponges, encrusting algae, and primitive coral. These carbonate buildups are only along the continental margins because the organisms were not adapted to the more restricted environments of the interior basin. 


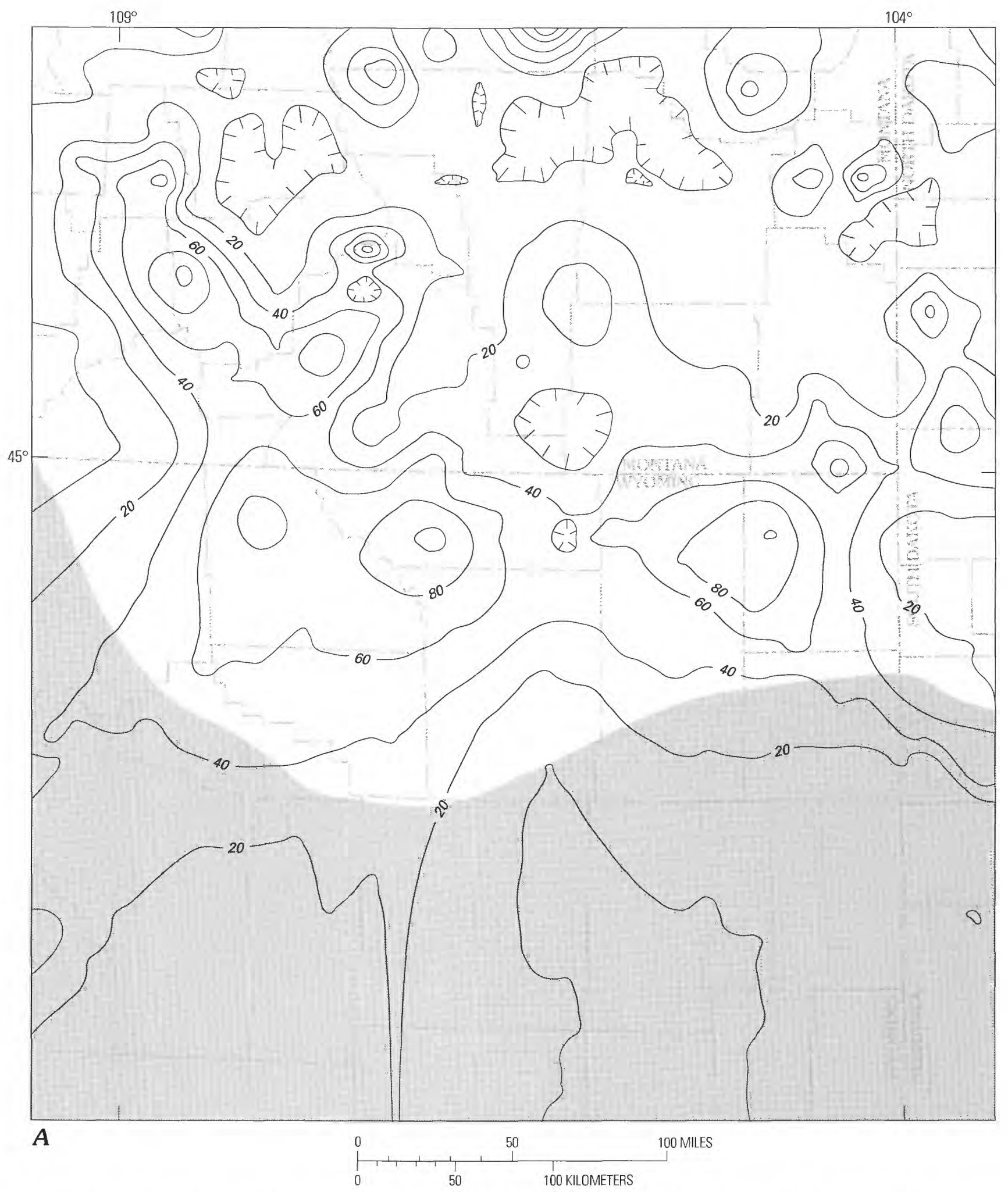

Figure 64. Feet of porosity greater than or equal to 10 percent in Madison Limestone (Group) intervals of stratigraphic sequence four. Based on 157 wells; gridded on an approximately $7 \mathrm{mi}$ by $7 \mathrm{mi}$ grid $(12 \mathrm{~km}$ by $12 \mathrm{~km})$. Map area shown in figure 3 . Screened area in southern part of map area is an area of very limited control. Data from Downey (1982). A, M1-M3 (approximately Kinderhookian); contour interval $20 \mathrm{ft}(6.1 \mathrm{~m})$. 


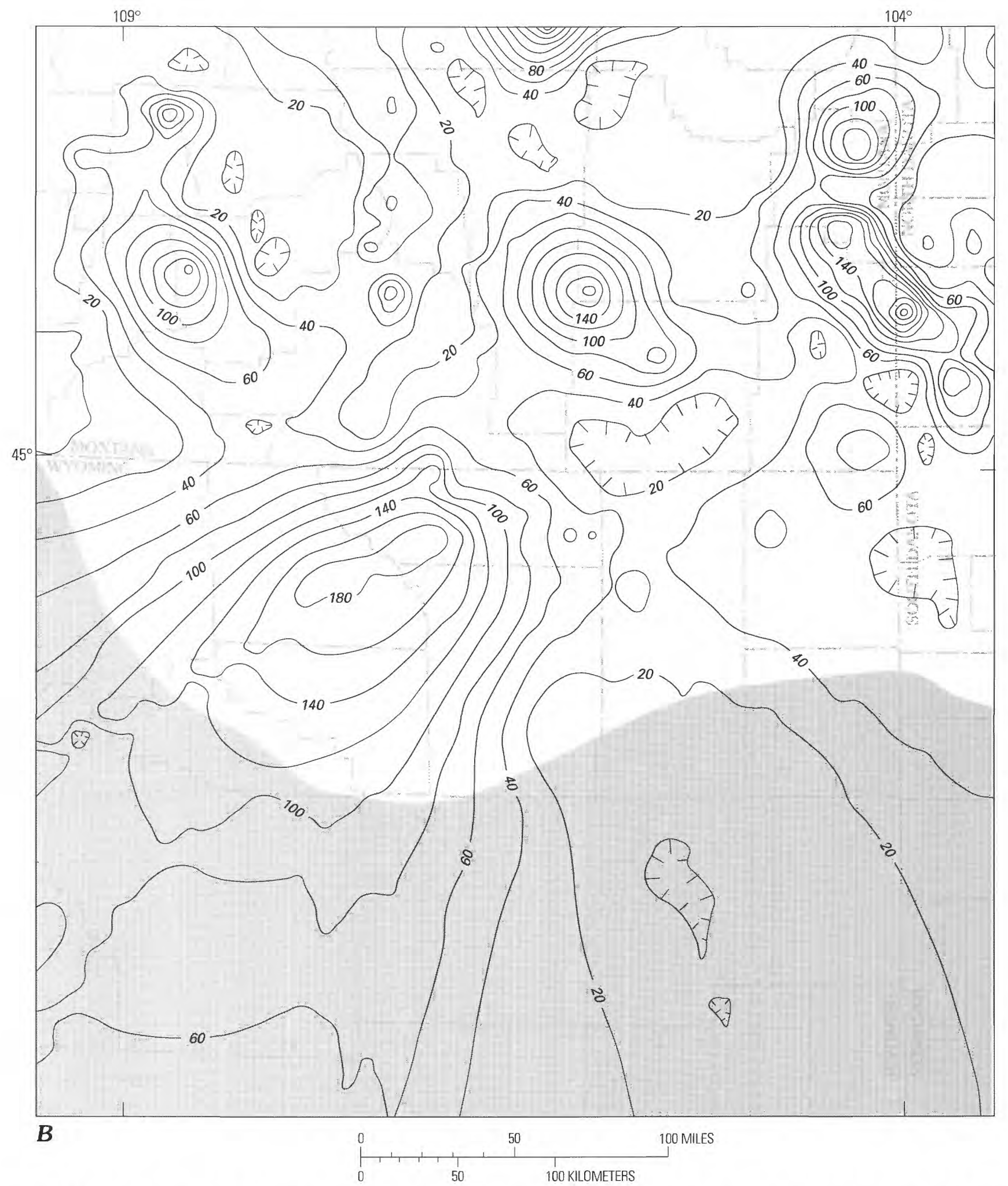

Figure 64 (continued). Feet of porosity greater than or equal to 10 percent in Madison Limestone (Group) intervals of stratigraphic sequence four. B, M3-M7 (lower Osagean); contour interval $20 \mathrm{ft}(6.1 \mathrm{~m})$. 


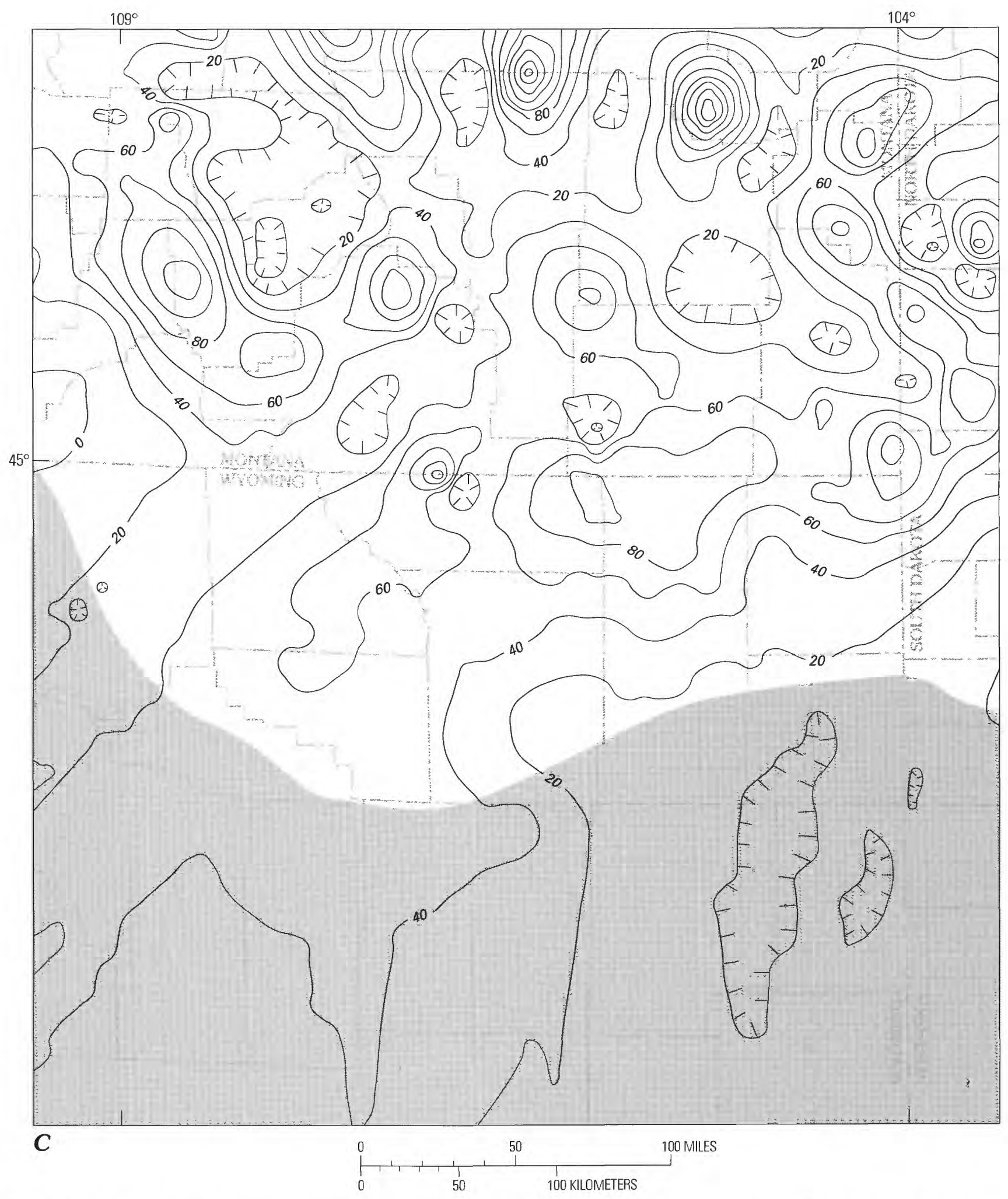

Figure 64 (continued). Feet of porosity greater than or equal to 10 percent in Madison Limestone (Group) intervals of stratigraphic sequence four. C, M7-M8.5 (middle Osagean); contour interval $20 \mathrm{ft}(6.1 \mathrm{~m})$. 


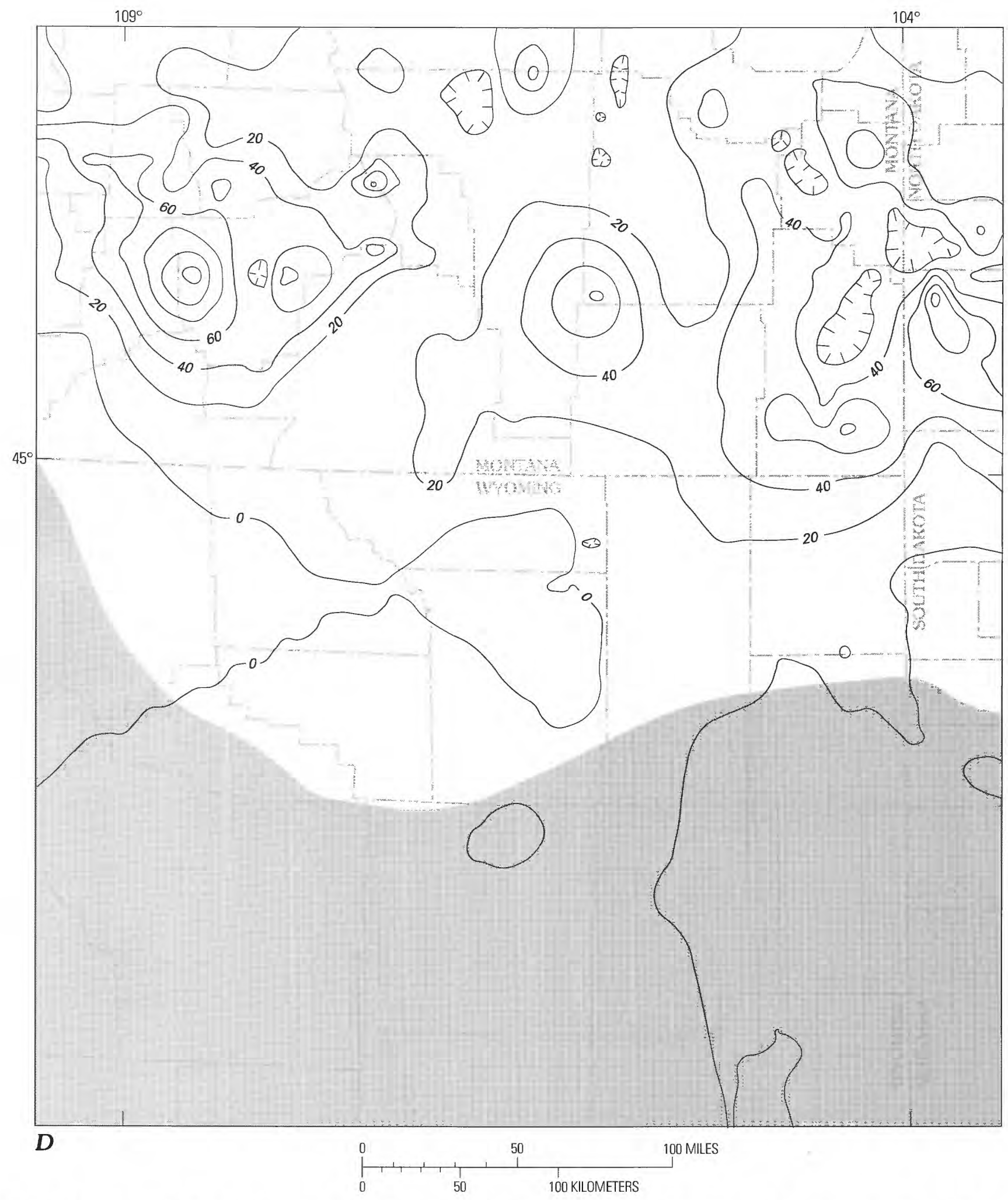

Figure 64 (continued). Feet of porosity greater than or equal to 10 percent in Madison Limestone (Group) intervals of stratigraphic sequence four. D, M8.5-M12 (upper Osagean); contour interval $20 \mathrm{ft}(6.1 \mathrm{~m})$. 


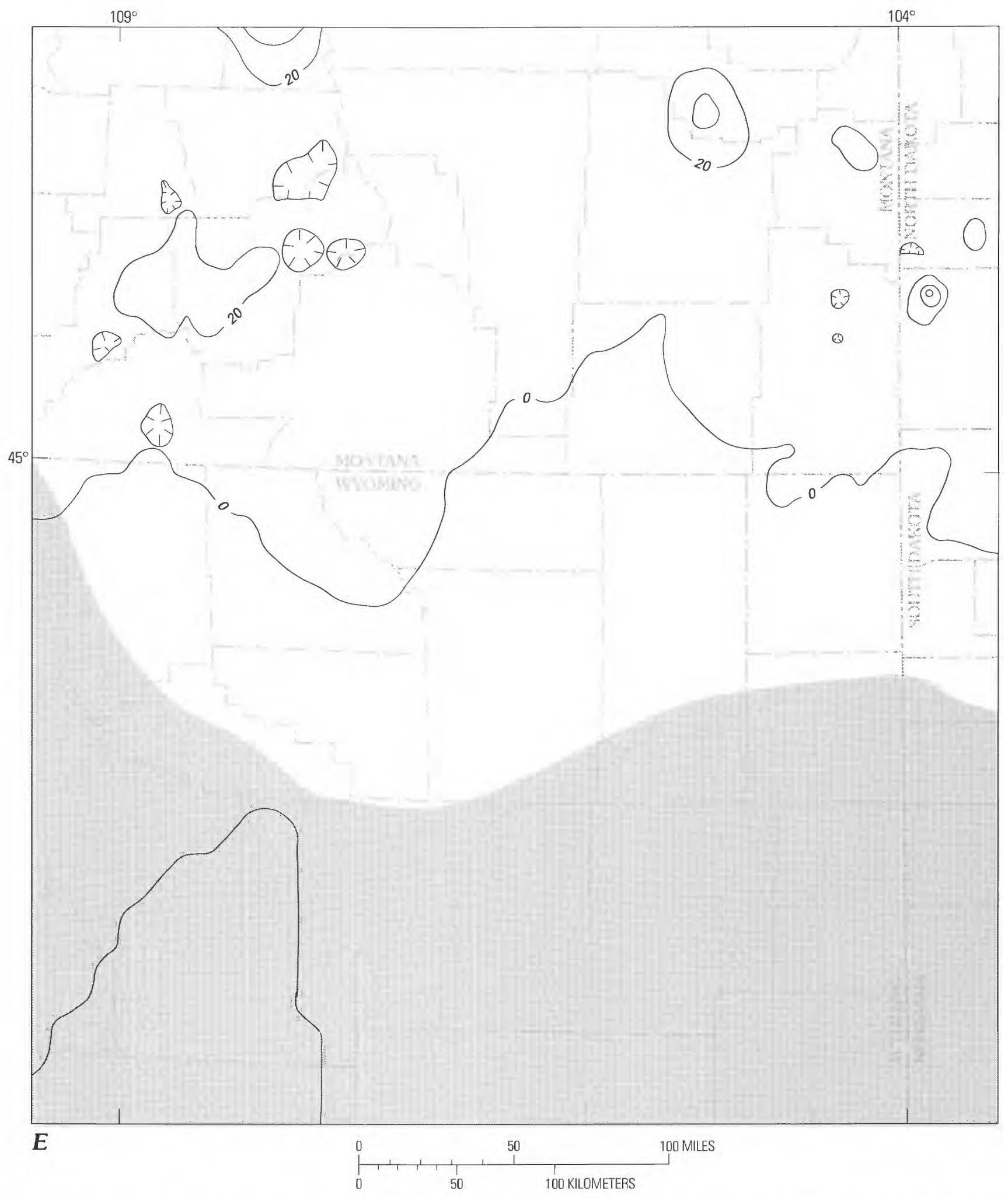

Figure 64 (continued). Feet of porosity greater than or equal to 10 percent in Madison Limestone (Group) intervals of stratigraphic sequence four. E, M12-Mc (lower? Meramecian); contour interval $20 \mathrm{ft}(6.1 \mathrm{~m})$. 


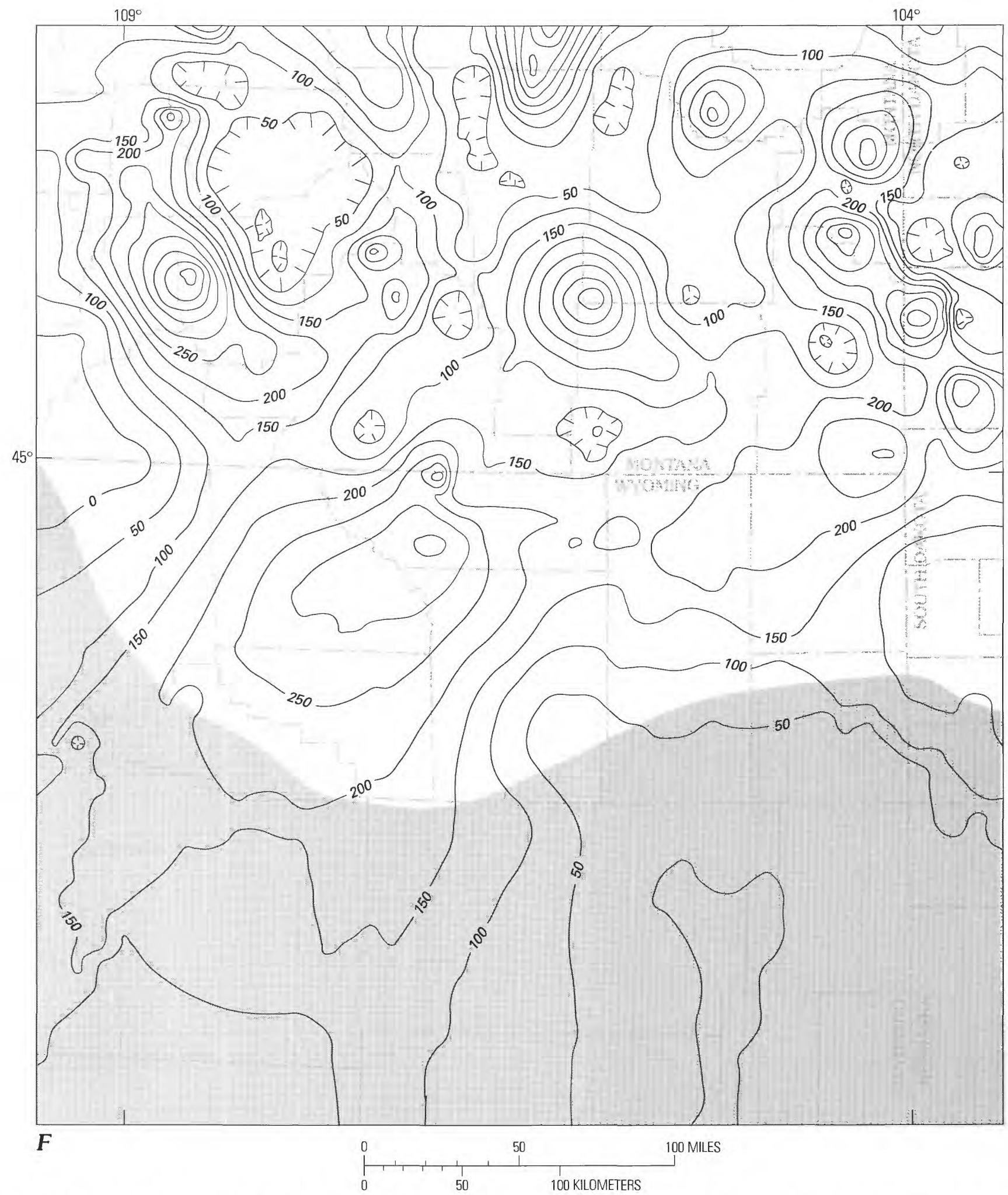

Figure 64 (continued). Feet of porosity greater than or equal to 10 percent in Madison Limestone (Group) intervals of stratigraphic sequence four. F, Total Madison Limestone Group interval; contour interval $50 \mathrm{ft}$ (15.2 m). 


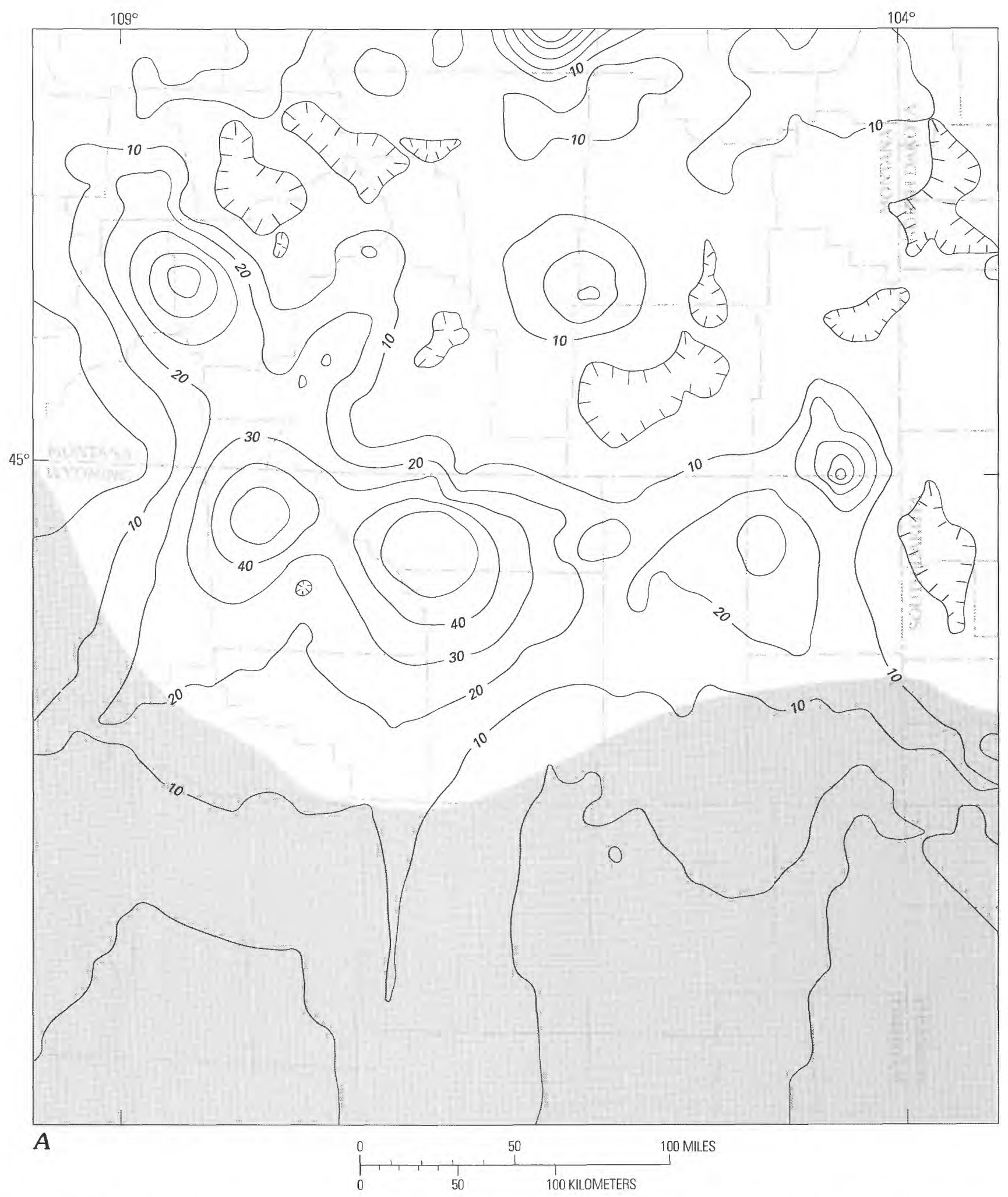

Figure 65. Feet of porosity greater than or equal to 15 percent in Madison Limestone (Group) intervals of stratigraphic sequence four. Based on 157 wells; gridded on an approximately $7 \mathrm{mi}$ by $7 \mathrm{mi}$ grid $(12 \mathrm{~km}$ by $12 \mathrm{~km})$. Map area shown in figure 3 . Screened area in southern part of map area is an area of very limited control. Data from Downey (1982). A, M1-M3 (approximately Kinderhookian); contour interval $10 \mathrm{ft}(3 \mathrm{~m})$. 


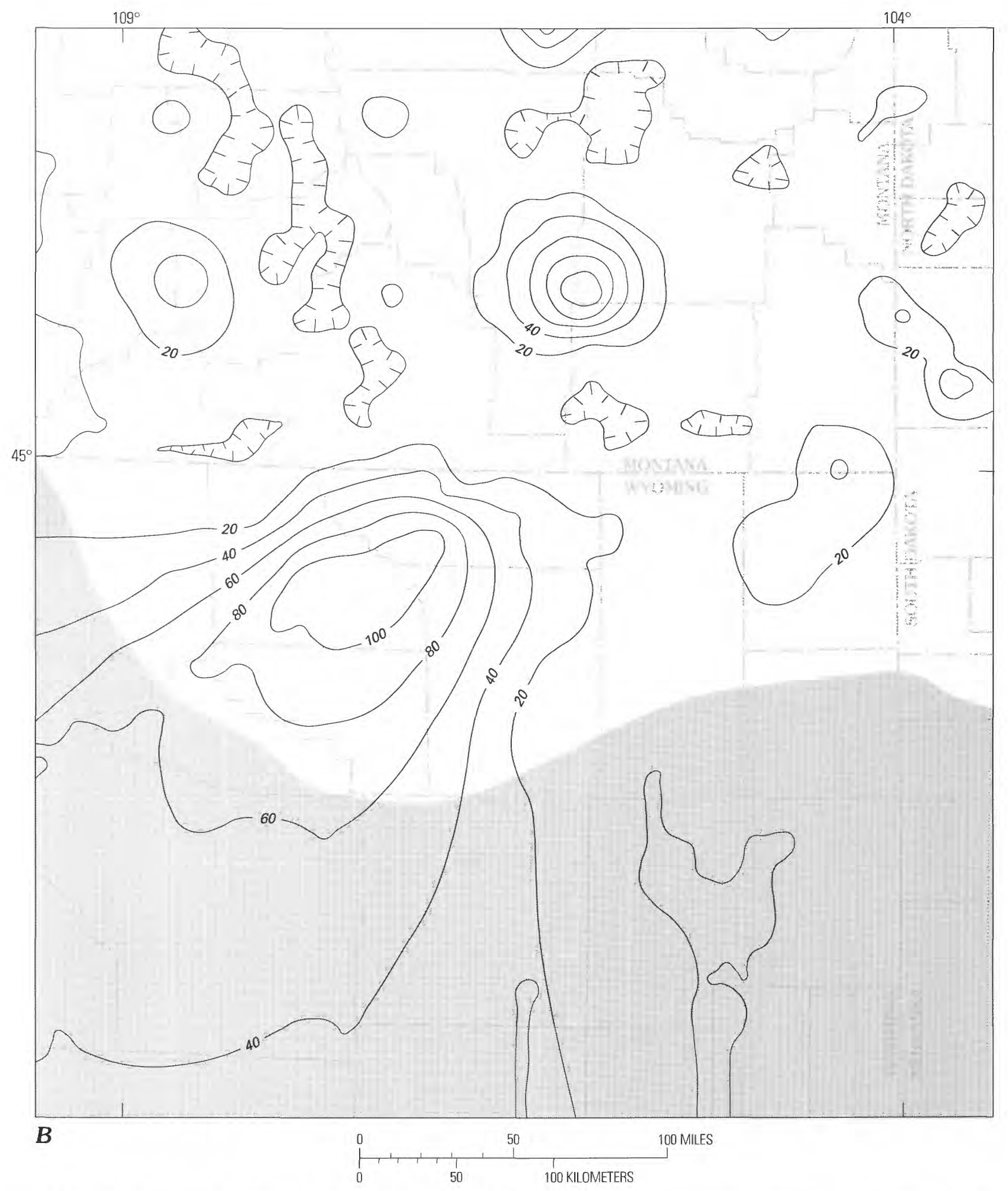

Figure 65 (continued). Feet of porosity greater than or equal to 15 percent in Madison Limestone (Group) intervals of stratigraphic sequence four. B, M3-M7 (lower Osagean); contour interval $20 \mathrm{ft}(6.1 \mathrm{~m})$. 


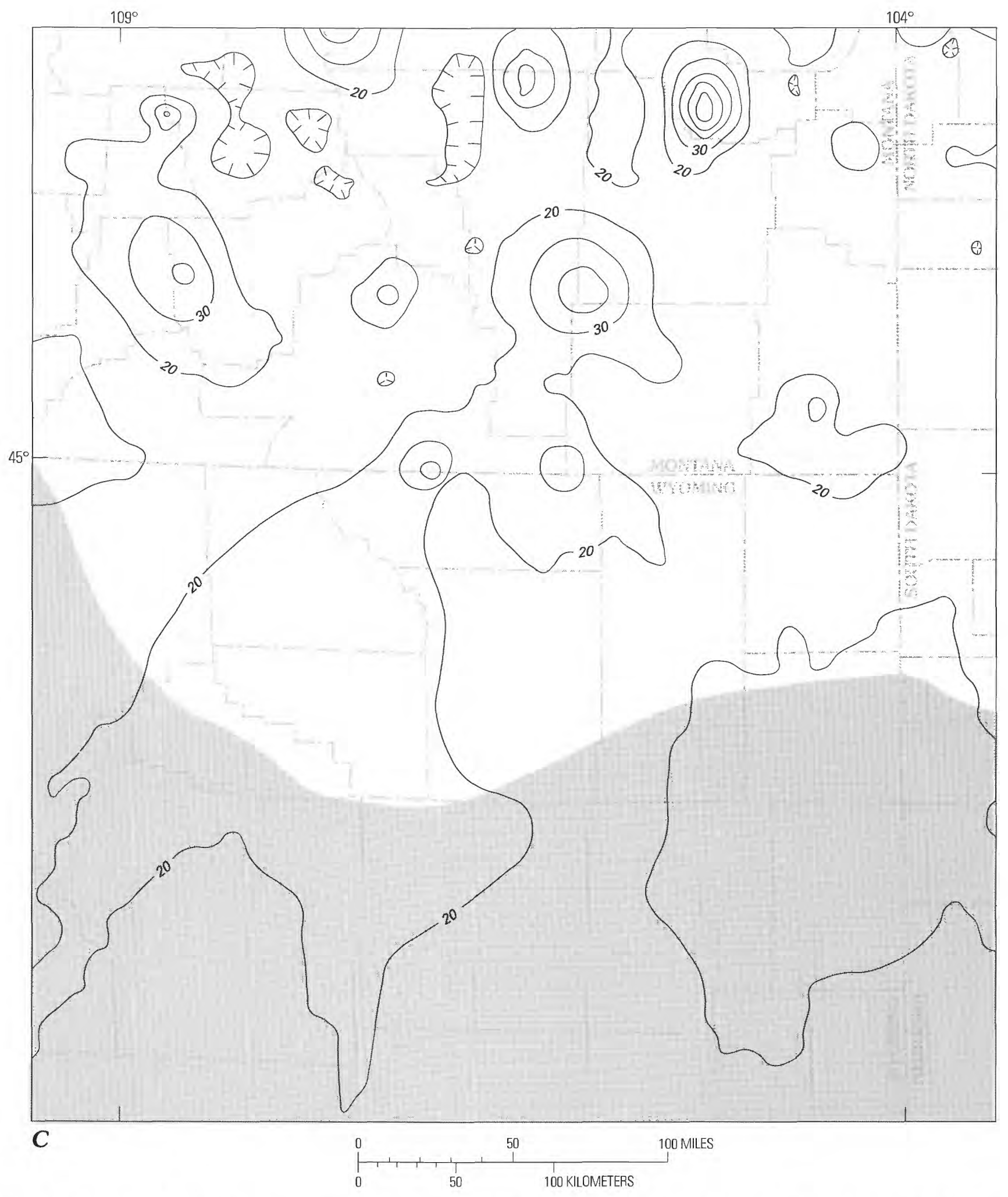

Figure 65 (continued). Feet of porosity greater than or equal to 15 percent in Madison Limestone (Group) intervals of stratigraphic sequence four. $C, M 7-M 8.5$ (middle Osagean); contour interval $10 \mathrm{ft}(3 \mathrm{~m})$. 


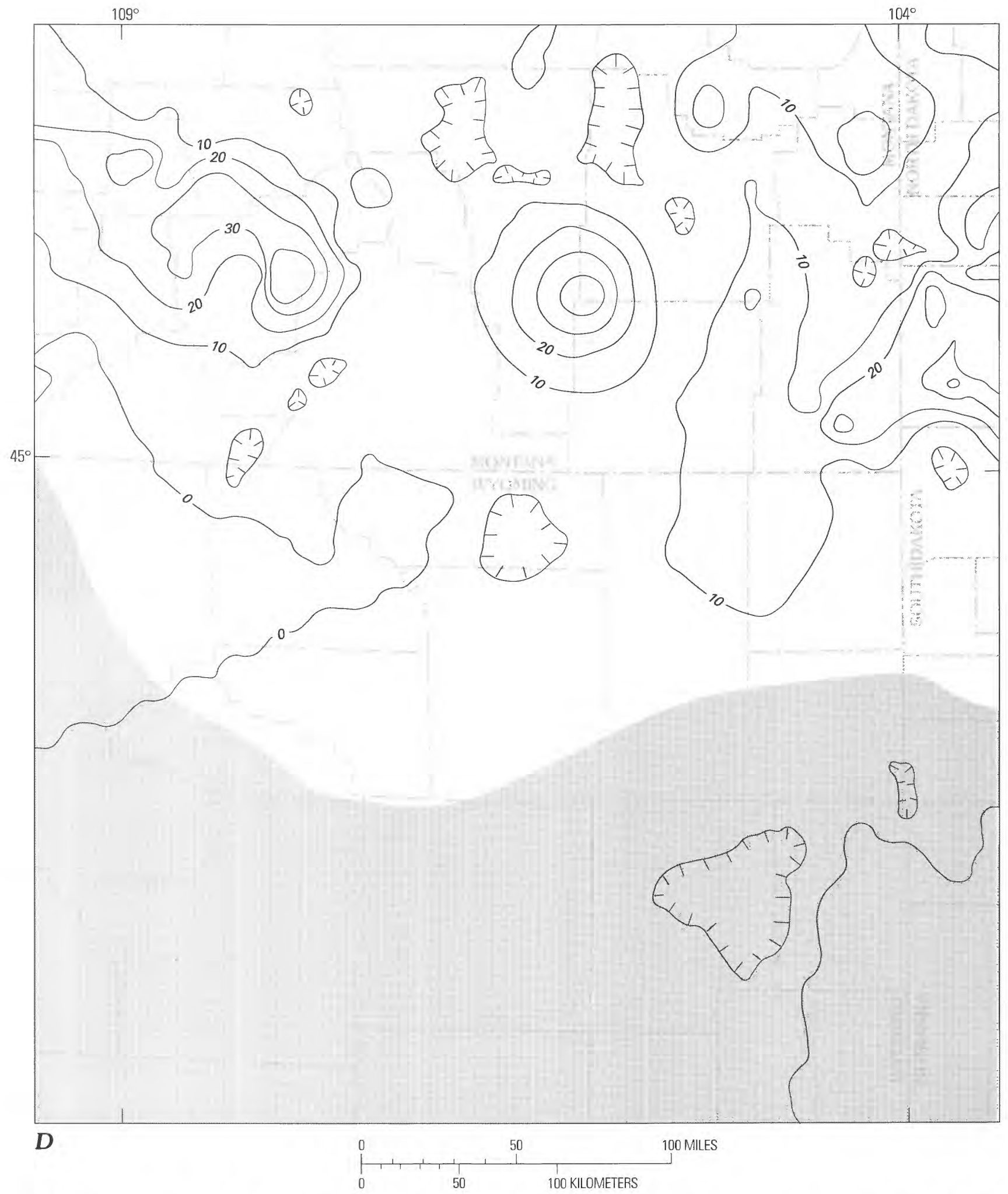

Figure 65 (continued). Feet of porosity greater than or equal to 15 percent in Madison Limestone (Group) intervals of stratigraphic sequence four. D, M8.5-M12 (upper Osagean); contour interval $10 \mathrm{ft}(3 \mathrm{~m})$. 


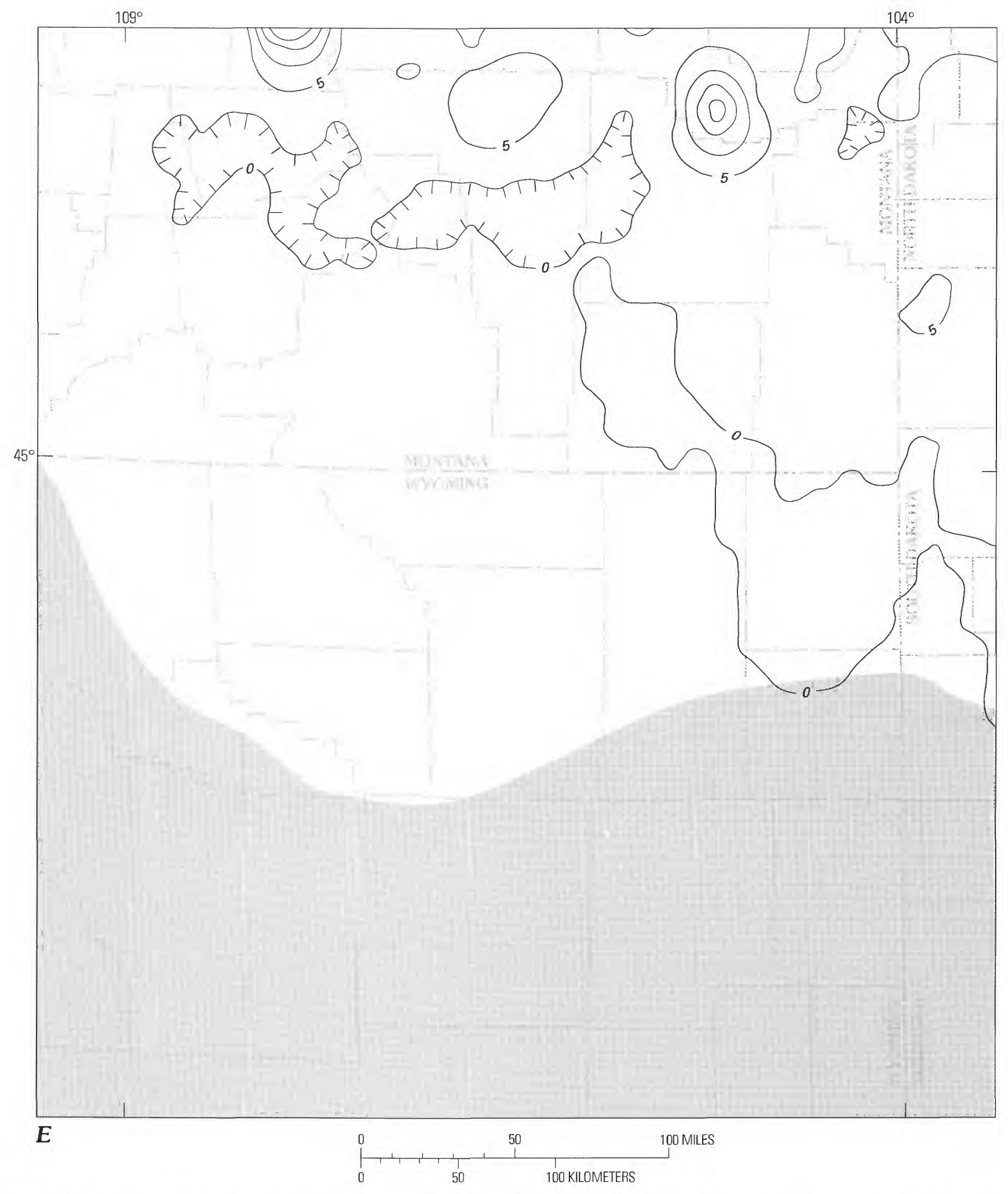

Figure 65 (continued). Feet of porosity greater than or equal to 15 percent in Madison Limestone (Group) intervals of stratigraphic sequence four. E, M12-Mc (lower? Meramecian); contour interval $5 \mathrm{ft}(1.5 \mathrm{~m})$. 


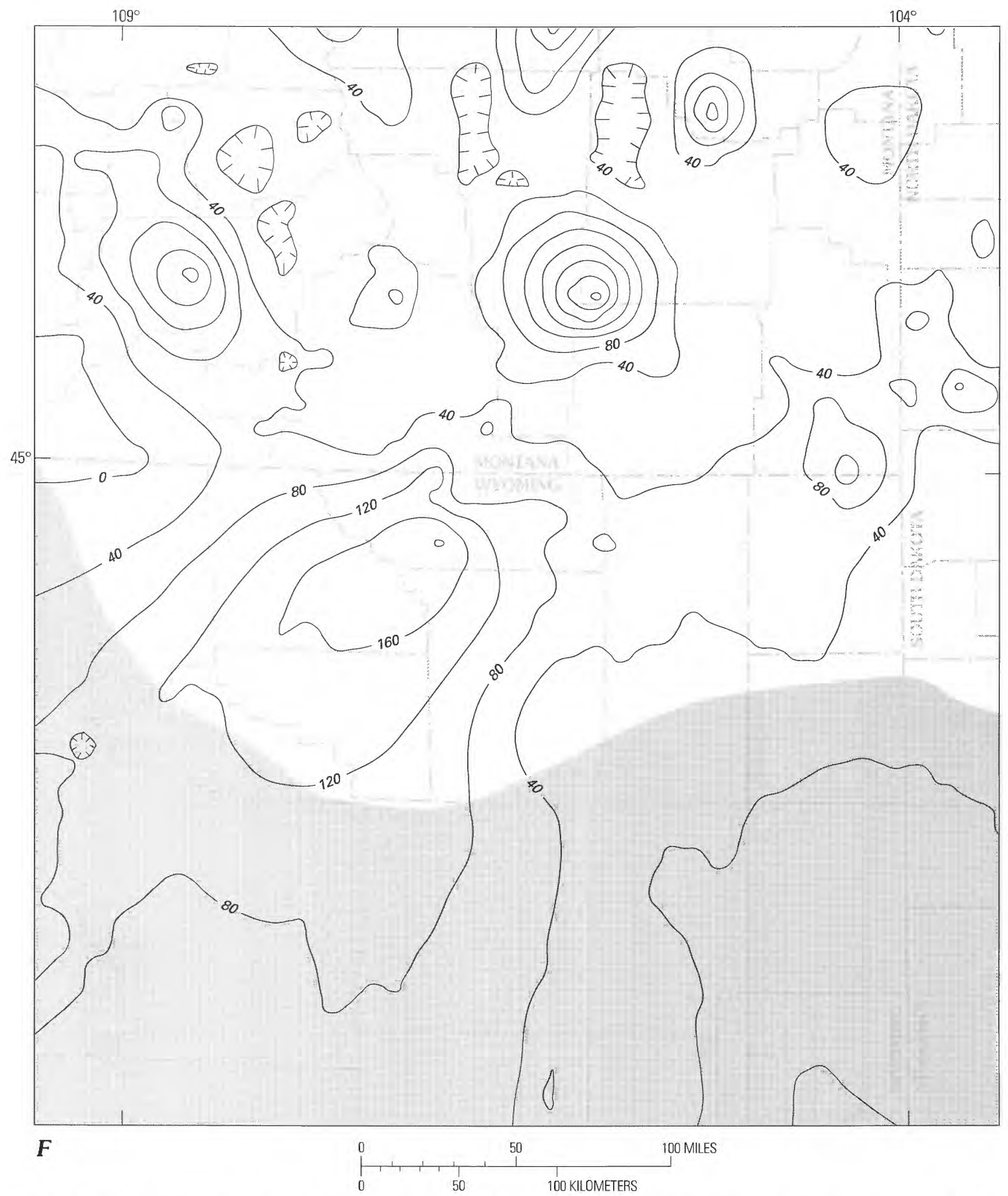

Figure 65 (continued). Feet of porosity greater than or equal to 15 percent in Madison Limestone (Group) intervals of stratigraphic sequence four. F, Total Madison Limestone Group interval; contour interval $40 \mathrm{ft}(12 \mathrm{~m})$. 
During the regression at the end of the Early Ordovician, organisms diversified and show great diversity in the Middle Ordovician shelf sequence. The most important changes include the appearance of large sessile benthic forms such as corals and stromatoporids. The most important steps in evolution, however, were the formation of ecological associations and an increase in the organisms' secretion of calcium carbonate. In large part, these biological changes led to deposition of sheet carbonates characteristic of Middle Ordovician time. The complexity of reef-building organisms increased through the Silurian until latest Devonian. Bryozoa are the main skeletal components of Ordovician and Silurian reefs but were replaced by corals in the Devonian. In latest Devonian time many of the important reef-building groups became extinct and the reef ecosystem collapsed.

In the Early Mississippian, pelmatozoa and bryozoa took the place of corals and stromatoporoids in biohermal development and Waulsortian mud mounds were the dominant form of carbonate buildup. The mud mounds were primarily restricted to the clear water of the deep shelves and continental margins. Most of the carbonate deposited on the shallow shelves represents landward transport of carbonate that is commonly reworked as massive oolite shoals.

Withdrawal of the sea in middle Meramecian time followed by deposition of the Big Snowy Group within the Central Montana trough may related to the initial deformation of the ancestral Rocky Mountain epeirorogeny. Middle Paleozoic sedimentation ended with development of the ancestral Rocky Mountain uplifts, which were probably related to the Ouachita orogeny along the southern cratonic margin. Block faulting associated with the ancestral Rocky Mountain epeirorogeny introduced an interval of uplift and erosion that produced an irregular surface on top of the lower Paleozoic sequence.

Acknowledgments.-This report was greatly enhance through discussions and comments of many people. J.A. Peterson (USGS) generously provided access to the data that is the basis of the work presented here, as well as stimulating discussions and continued encouragement. E.K. Maughan (USGS, retired) critically read the manuscript and reviewed portions of it, generously offered his time, both in the field and innumerable discussions, and provided access to unpublished data. W.W. Mallory, (USGS, retired) also read the manuscript and offered numerous suggestions. K.M. Nichols (USGS) reviewed portions of the manuscript and engaged in many useful discussions on the Paleozoic rocks of the Western United States. Discussions with C.A. Sandberg (USGS) greatly influenced the content of this report. Special thanks is due to E.A. Merewether, Evolution of Sedimentary Basins-Powder River Basin Project Coordinator, who offered unfaltering support.
N.J. Silberling (USGS) and W.L. Bilodeau (California Lutheran University) critically reviewed the manuscript and offered many helpful suggestions. Much of the paleotectonic interpretation in this report was developed under the guidance of Dr. Bilodeau while at the University of Colorado at Denver.

\section{SELECTED REFERENCES}

Adler, F.J., coordinator, 1987, Mid-continent region, correlation of stratigraphic units of North America (COSUNA) project chart: American Association of Petroleum Geologists, 1 sheet.

Agatson, R.S., 1954, Pennsylvanian and Lower Permian of northern and eastern Wyoming: American Association of Petroleum Geologists Bulletin, v. 38, no. 4, p. 508-583.

Ahern, J.L., and Mrkvicka, S.R., 1984, A mechanical and thermal model for the evolution of the Williston Basin: Tectonics, v. 3, no. 1, p. 79-102.

Aitken, J.D., 1966, Middle Cambrian to Middle Ordovician cyclic sedimentation, southern Rocky Mountains of Alberta: Bulletin of Canadian Petroleum Geology, v. 14, no. 4, p. $405-441$.

1968, Cambrian sections in easternmost southern Rocky Mountains and adjacent areas, Alberta: Geological Survey of Canada Paper 66-23, $96 \mathrm{p}$.

1978, Revised models for depositional grand cycles, Cambrian of the southern Canadian Rocky Mountains: Canadian Petroleum Geology Bulletin, v. 26, p. 515-542.

1981a, Cambrian stratigraphy and depositional fabrics, southern Canadian Rocky Mountains, Alberta and British Columbia, in Taylor, M.E., ed., Guidebook for field trip 2: Second International Symposium of the Cambrian System, p. 1-27.

1981b, Generalizations about grand cycles, in Taylor, M.E., ed., Short papers for the Second International Symposium on the Cambrian: U.S. Geological Survey Open-File Report 81-743, p. 8-14.

Allmendinger, R.W., Brewer, J.A., Brown, D.L., Kaufman, S., Oliver, J.E., and Huston, R.S., 1982, COCORP profiling across the Rocky Mountain Front in southern Wyoming-Part 2, Precambrian basement structure and its influence on Laramide deformation: Geological Society of America Bulletin, v. 93, no. 12, p. 1254-1263.

Alpha, A.G., 1958, Tectonic history of Montana, in Zieglar, D.L., ed., Beartooth uplift and Sunlight Basin: Billings Geological Society Annual Field Conference Guidebook 9, p. $57-68$.

Anderson, T.C.. 1982, Exploration history and hydrocarbon potential of the Ordovician Winnipeg Formation in the southern Williston Basin, in Christopher, J.E., and Kaldi, J., eds., Fourth International Williston Basin Symposium Proceedings: Saskatchewan Geological Society Special Publication 6, p. 19-25.

Andrichuk, J.M., 1951, Regional stratigraphic analysis of the Devonian System in Wyoming, Montana, and southern 
Saskatchewan and Alberta: American Association of Petroleum Geologists Bulletin, v. 35, no. 11, p. 2368-2408. 1955, Mississippian Madison Group stratigraphy and sedimentation in Wyoming and southern Montana: American Association of Petroleum Geologists Bulletin, v. 39 , no. 11 , p. 2170-2210.

1959. Ordovician and Silurian stratigraphy and sedimentation in southern Manitoba, Canada: American Association of Petroleum Geologists Bulletin, v. 43, p. 2333-2398.

Armin, R.A., and Mayer, Larry, 1983, Subsidence analysis of Cordilleran miogeocline-Implications for timing of Late Paleozoic rifting and amount of extension: Geology, v. 11, no. 12 , p. 702-705.

Armstrong, A.K., 1958, The Mississippian of west-central New Mexico: New Mexico Bureau of Mineral Resources Memoir 5, $32 \mathrm{p}$.

Atherton. Elwood, Collinson, Charles, and Lineback, J.A., 1975 , Mississippian System, in Willman, H.B., Atherton, Elwood, Buschbach, T.C., Collinson, Charles, Frye, J.C, Hopkins, M.E., Lineback, J.A., and Simmon, J.A., eds., Handbook of Illinois stratigraphy: Illinois State Geological Survey Bulletin 95, p. 123-163.

Baars, D.L., 1972, Devonian System, in Mallory, W.W., ed., Geologic atlas of the Rocky Mountain region: Rocky Mountain Association of Geologists, p. 90-99.

Baillie, A.D., 1951, Silurian geology of the Interlake area, Manitoba: Manitoba Department of Mines and Natural Resources Mines Branch Publication 50-1, 82 p.

1955. Devonian System of Williston Basin: American Association of Petroleum Geologists Bulletin, v. 39 , p. 575-629.

Baillie, A.D., ed., 1950, Devonian geology of the Lake Manitoba-Lake Winnepegosis area: Manitoba Department of Mines and Natural Resources Mines Branch Publication 49-2, 72 p.

1952, Ordovician geology of Lake Winnipeg and adjacent areas: Manitoba Department of Mines and Natural Resources Mines Branch Publication 51-6, 64 p.

1953, Devonian System of the Williston Basin area: Manitoba Department of Mines and Natural Resources Mines Branch Publication 52-5, 105 p.

Ballard, W.W., Bluemle, J.P., and Gerhard, L.C., coordinators, 1983. Northern Rockies/Williston Basin region, correlation of stratigraphic units of North America (COSUNA) project chart: American Association of Petroleum Geologists, 1 sheet.

Barnes, C.R., Jackson, D.E., and Norford, B.S., 1976, Correlations between Canadian Ordovician zonations based on graptolites, conodonts, and benthic macrofossils from key successions, in Bassett. M.G., ed., The Ordovician System-Proceedings of a Paleontological Association Symposium: Cardiff, University of Wales Press and National Museum of Wales, p. 209-226.

Bates, R.L., 1955, Permo-Pennsylvanian formations between Laramie Mountains and the Black Hills. South Dakota: American Association of Petroleum Geologists Bulletin, v. 39, p. 1979-2002.

Bell, L.H., 1970, Depositional history of the Cambrian Flathead Sandstone, Park County, Wyoming, in Enyert, R.L., ed.,
Symposium on Wyoming Sandstones: Wyoming Geological Association Annual Field Conference Guidebook 22, p. 115-131.

Bell, L.H., and Middleton, L.T., 1978, An introduction to the Cambrian Flathead Sandstone, Wind River Basin, Wyoming, in Boyd, R.G., ed., Resources of the Wind River Basin: Wyoming Geological Association Annual Field Conference Guidebook 30, p. 79-88.

Bell, W.C., 1941, Cambrian Brachiopoda from Montana: Journal of Paleontology, v. 15, p. 193-255.

Bender, Hans, 1958, Ein Querprofil dur den Westteil der Hörren und ihre "Phyllite" (Ulmbachtal; Rheinisches Schiefergebirge): Notizblatt des Hessischen Landesamtes füer Bodenforschung. Wiesbaden, v. 87, p. 78-88.

Bennett, V.C., and DePaolo, D.J., 1987, Proterozoic crustal history of the western United States as determined by neodymium isotopic mapping: Geological Society of America Bulletin, v. 99, p. 674-685.

Benson, A.L., 1966, Devonian stratigraphy of western Wyoming and adjacent areas: American Association of Petroleum Geologists Bulletin, v. 50, no. 12, p. 2566-2603.

Berry, W.B.N., 1976, Aspects of correlation of North American shelly and graptolitic fauna, in Bassett, M.G., ed., The Ordovician System-Proceedings of a Paleontological Association Symposium: Cardiff, University of Wales Press and National Museum of Wales, p. 153-196.

Bijorlie, P.F., ed., 1979, The Carrington Shale facies (Mississippian) and its relationship to the Scallion subinterval in central North Dakota: North Dakota Geological Survey Report of Investigations 67, 46 p.

Bijorlie, P.F., and Anderson, S.B., 1978, Stratigraphy and depositional setting of the Carrington Shale facies (Mississippian) of the Williston Basin, in Estelle, Duane, and Miller, Roger, eds., Williston Basin Symposium: Montana Geological Society Annual Field Conference, 24th, p. 165-176.

Birchfield, B.C., and Davis, G.A., 1972, Structural framework and evolution of the southern part of the Cordilleran orogen, western United States: American Journal of Science, v. 272 , p. 97-118.

Bishoff, Günter, and Ziegler, Willi, 1965, Das Alter der "Urfer Schichten" im Marburger Hinderland nach Conodonten: Notizblatt des Hessischen Landesamtes füer Bodenforschung. Wiesbaden, v. 84, p. 138-169, pls. 11-14.

Blackstone, D.L., Jr., 1949. Structural pattern of the Powder River Basin, in Jenkins, P.T., ed., Powder River Basin: Wyoming Geological Association Annual Field Conference Guidebook 4, p. 35-36.

1981 , Compression as an agent in deformation of the eastcentral flank of the Bighorn Mountains, Sheridan and Johnson Counties, Wyoming: University of Wyoming Contributions to Geology, v. 19, no. 2, p. 105-122.

Blackstone, D.L., Jr., and McGrew, P.O., 1954, New occurrences of Devonian rocks in north central Wyoming, in Richards, P.W., ed., Pryor Mountains-Northern Bighorn Basin, Montana: Billings Geological Society Annual Field Conference Guidebook 5, p. 38-43.

Bluemle, J.P., Anderson, S.B., Andrew, J.A., Fischer, D.W., and LeFever, J.A., 1986, North Dakota stratigraphic column: 
North Dakota Geological Survey Miscellaneous Series 66 , 3 sheets.

Bluemle, J.P., Anderson, S.B., and Carlson, C.G., 1981, Williston Basin stratigraphic nomenclature chart: North Dakota Geological Survey Miscellaneous Series 61, 1 sheet.

Bond, G.C., and Kominz, M.A., 1981, The problem of subsidence mechanisms for the Lower Paleozoic stratigraphic succession in the southern Canadian Rocky Mountains: Geological Society of America Abstracts with Program, v. 13, p. 191.

Bond, G.C., Kominz, M.A., and Devlin, W.J., 1983, Thermal subsidence and eustacy in the Lower Paleozoic miogeocline of western North America: Nature, v. 306, nos. 22/29, p. 375-379.

Boucot, A.J. and others, 1974, Middle Devonian orogeny in western North America?-A fish and other fossils: Journal of Geology, v. 82, p. 691-708.

Boyde, D.W., 1966, Lamination deformation by burrowers in Flathead Sandstone (Middle Cambrian) of central Wyoming: University of Wyoming Contributions to Geology, v. 5, p. 43-53.

Brett, C.E., Liddell, W.D., and Derstler, K.L., 1983, Late Cambrian hard substrate communities from Montana/Wyoming-The oldest known hardground encrusters: Lethaia, v. 16, no. 4, p. 281-289.

Brindle, J.E., ed., 1960, The faunas of the Lower Paleozoic carbonate rocks in the subsurface of Saskatchewan: Saskatchewan Department of Mineral Resources Report 52 , $45 \mathrm{p}$.

Brown, D.L., 1978, Wrench-style deformational patters associated with a meridonal stress axis recognized in Paleozoic rocks in parts of Montana, South Dakota, and Wyoming, in Estelle, Duane, and Miller, Roger, eds., The economic geology of the Williston Basin: Billings Geological Society Annual Conference, 24th, p. 17-31.

Brown, D.L., Blankennagel, R.K., MacCary, L.M., and Peterson, J.A., 1982, Correlation of paleostructure and sediment deposition in the Madison Limestone and associated rocks in parts of Montana, North Dakota, South Dakota, Wyoming, and Nebraska: U.S. Geological Survey OpenFile Report 82-09096, 80 p.

Brown, D.L., and others, 1984, Correlation of paleostructure and sediment deposition in the Madison Limestone and associated rocks in parts of Montana, South Dakota, North Dakota, and Nebraska: U.S. Geological Survey Professional Paper 1273-B, 24 p.

Butler, J.R., Battin, R.L., Plank, R.F., and Winston, D.B., 1955, Lithologic correlation of Middle and Lower Paleozoic rocks, in Swartz, Joe, and others, eds., South Dakota Black Hills: North Dakota Geological Society Annual Field Conference Guidebook 3, p. 38-42.

Carlson. C.G., 1958, The stratigraphy of the Deadwood-Winnipeg interval in North Dakota and northwestern South Dakota, in Cumming, A.D., ed., Second International Williston Basin Symposium Proceedings: North Dakota Geological Survey-Saskatchewan Geological Survey, p. 20-26.

1960, Stratigraphy of the Winnipeg and Deadwood Formations in North Dakota: North Dakota Geological Survey Bulletin 35, 149 p.
Carlson, C.G., and Anderson, S.B., 1965, Sedimentary and tectonic history of North Dakota part of Williston Basin: American Association of Petroleum Geologists Bulletin, v. 49. p. 1833-1846.

Carlson, C.G., and Eastwood, W.P., 1962, Upper Ordovician and Silurian rocks of North Dakota: North Dakota Geological Survey Bulletin 38, 52 p.

Carlson, C.G., and LeFever, J.A., 1987, The Madison, a nomenclatural review with a look to the future, in Carlson, C.G., and Christopher, J.E., eds., Fifth International Williston Basin Symposium, Regina, Saskatchewan: Saskatchewan Geological Society Special Publication 9, p. 77-82.

Carroll, W.K., 1979, Depositional environments and paragenetic porosity controls, upper Red River Formation, North Dakota: North Dakota Geological Survey Report of Investigations $66,51 \mathrm{p}$.

Cavanaugh, M.D., and Seyfert, C.K., 1977, Apparent polar wander paths and the joining of the Superior and Slave provinces during early Proterozoic time: Geology, v. 5, no. 4, p. 207-211.

Cecile, M.P., 1978, Report on Road River stratigraphy and the Misty Creek embayment, Bonnet Plume and surrounding areas, Northwest Territories: Canada Geological Survey Paper 78-1A, p. 207-211.

1982, The Lower Paleozoic Misty Creek embayment, Selwyn Basin, Yukon and Northwest Territories: Canada Geological Survey Bulletin 335, 78 p.

Chapin, C.L., and Cather, S.M., 1983, Eocene tectonics and sedimentation in the Colorado Plateau-Rocky Mountain area, in Lowell, J., ed., Rocky Mountain basins and uplifts: Rocky Mountain Association of Geologists, p. 33-56.

Chaudhuri, S., and Brookins, D.G., 1969, The isotopic age of the Flathead Sandstone (Middle Cambrian), Montana: Journal of Sedimentary Petrology, v. 39, p. 364-368.

Christopher, J.E., 1962, The Three Forks Group (Upper Devonian-Kinderhookian) of southern Saskatchewan, in Hansen, A.R., and McKeever, J.H., eds., Three Forks-Belt Mountains Area-The Devonian System of Montana and adjacent areas: Billings Geological Society Annual Field Conference Guidebook 13, p. 67-77.

Chronic, J., and others, 1969, Lower Paleozoic rocks in diatremes, southern Wyoming and northern Colorado: Geological Society of America Bulletin, v. 80, p. 146-156.

Church, S.B., 1974, Sponge-algal reefs in the Lower Ordovician Pogonip Group, western Utah: Geological Society of America Abstracts with Program, v. 6, no. 3, p. 155.

Churkin, Michael, Jr., 1974, Paleozoic marginal ocean basinvolcanic arc system in the Cordilleran foldbelt, in Dott, R.H., Jr., and Shaver, R.H., eds., Modern and ancient geosynclinal sedimentation: Society of Economic Paleontologists and Mineralogists Special Publication 19. p. 174-192.

Cloud, Preston, and Dever, J.R., 1973, Trace fossils from the Flathead Sandstone, Fremont County, Wyoming, compared with early Cambrian forms from California and Australia: Journal of Paleontology, v. 47, p. 883-885.

Cohen, C.R., 1982, Model for a passive to active continental margin transition: American Association of Petroleum Geologists Bulletin, v. 66, no. 6, p. 708-718. 
Coles, K.S., and others, 1983, Tectonic subsidence of the Lower to Middle Paleozoic Cordillerian miogeocline in the eastern Great Basin: Geological Society of America Abstracts with Program, v. 15, no. 5, p. 404.

Collier, A.J., and Cathcart, S.H., 1922, Possibility of finding oil in laccolithic domes south of the Little Rocky Mountains, Montana: U.S. Geological Survey Bulletin 736-F, p. 171-178.

Collinson, C.W., 1961, Kinderhookian Series in the Mississippi Valley, in Malone, D.J., ed., Northeastern Missouri and west-central Illinois: Kansas Geological Society Annual Field Conference Guidebook 26, p. 100-109.

Condie, K.C., and Shadel, C.A., 1983, An early Proterozoic volcanic arc succession in southern Wyoming: Canadian Journal of Earth Sciences, v. 21, p. 415-427.

Condra, G.E., Reed, E.C., and Scherer, O.J., 1940, Correlation of the formations of the Laramie Range, Hartville uplift, Black Hills, and western Nebraska: Nebraska Geological Survey Bulletin 13, 2nd ser., 52 p.

Condra, G.E., Schramm, E.F., and Lugn, A.L., 1931, Deep wells of Nebraska: Nebraska Geological Survey Bulletin 4, 2nd ser., 74 p.

Cook, T.D., and Bally, A.W., eds., 1975, Stratigraphic atlas of North and Central America: Princeton, N.J., Princeton University Press, 272 p.

Cooley, M.E., 1986, Divisions of potential fracture permeability based on distribution of structures and linear features in sedimentary rocks, Northern Great Plains-Rocky Mountain region of Montana, North Dakota, South Dakota, Wyoming, and northern Nebraska: U.S. Geological Survey Miscellaneous Investigations Map I-1687, scale 1:335,000.

Cooper, C.L., and Sloss, L.L., 1943, Devonian conodonts from northwestern Montana and Alberta: Journal of Paleontology, v. 17, p. 168-176.

Cotter, E.J., 1965, Waulsortian-type carbonate banks in the Mississippian Lodgepole Formation of central Montana: Journal of Geology, v. 73, p. 881-888.

Craig, L.C., 1972, Mississippian System, in Mallory, W.W., ed., Geologic atlas of the Rocky Mountain region: Rocky Mountain Association of Geologists, p. 100-110.

Craig, L.C., and Connor, C.W., coordinators, 1979, Paleotectonic investigations of the Mississippian System in the United States: U.S. Geological Survey Professional Paper 1010 , $559 \mathrm{p}$.

Darton, N.H., 1901, Preliminary description of the geology and water resources of the southern half of the Black Hills and adjoining regions in South Dakota and Wyoming-Part 4, Hydrology: U.S. Geological Survey 21st Annual Report, p. 489-599.

1909. Geology and water resources of the northern portion of the Black Hills and adjoining regions in South Dakota and Wyoming: U.S. Geological Survey Professional Paper $65,105 \mathrm{p}$.

Darton, N.H., and Page, Sidney, 1925, Description of the central Black Hills: U.S. Geological Survey Geologic Atlas of the United States Folio 219, 34 p.

Deiss, Charles, 1933, Paleozoic formations of northwestern Montana: Montana Bureau of Mines and Geology Memoir $6,50 \mathrm{p}$.
1936, Revision of type Cambrian formations of Montana and Yellowstone National Park: Geological Society of America Bulletin, v. 47, p. 1257-1342.

1938, Cambrian formations and sections in part of Cordilleran trough: Geological Society of America Bulletin, v. 49, no. 7, p. 1067-1168.

1939. Cambrian stratigraphy and trilobites of northwestern Montana: Geological Society of America Special Paper 18, $135 \mathrm{p}$.

Dickinson, W.R., 1974, Plate tectonics and sedimentation, in Dickinson, W.R., ed., Tectonics and sedimentation: Society of Economic Paleontologists and Mineralogists Special Publication 21, p. 1-28.

1977, Paleozoic plate tectonics and the evolution of the Cordilleran continental margin, in Stewart, J.H., Stevens, C.H., and Fritsche, A.E., eds., Paleozoic paleogeography of the western United States: Pacific Coast Section, Society of Economic Paleontologists and Mineralogists Paleogeography Symposium 1, p. 137-155.

1981. Plate tectonic evolution of the southern Cordillera in Dickinson, W.R., and Payne, W.D., eds., Relations of tectonics to ore deposits in the southern Cordillera: Arizona Geological Society Digest, v. 14, p. 133-135.

Dorf, Erling, 1933, A new occurrence of the oldest known terrestrial vegetation from Beartooth Butte, Wyoming: Botanical Gazetteer, v. 95, p. 240-257.

1934a, Lower Devonian flora from Beartooth Butte, Wyoming: Geological Society of America Bulletin, v. 45, no. 3, p. $425-440$.

1934b. Stratigraphy and paleontology of a new Devonian formation at Beartooth Butte, Wyoming: Journal of Geology, v. 42, no. 7. p. 720-737.

Dorf, Erling, and Lochman, Christina, 1938, Upper Cambrian formations of southern Montana [abs.]: Geological Society of America Proceedings for 1937, p. 276.

1940, Upper Cambrian formations in southern Montana: Geological Society of America Bulletin, v. 51, p. 541-556.

Dover, J.H., 1980, Status of the Antler orogeny in central Idaho-Clarifications and constraints from the Pioneer Mountains, in Fouch, T.D., and Megathan, E.R., eds., Paleozoic paleogeography of west-central United States: Rocky Mountain Section, Society of Economic Paleontologists and Mineralogists West-Central United States Paleogeography Symposium 1, p. 371-386.

Dow, W.G., 1974, Application of oil-correlation and source-rock data to exploration in Williston Basin: American Association of Petroleum Geologists Bulletin, v. 58, no. 7, p. 1253-1262.

Dowling, D.B., 1900, Report on the geology of the west shore and islands of Lake Winnipeg: Canada Geological Survey Annual Report 11, chapter F. 100 p.

Downey, J.S., 1982, Machine-readable data files from the Madison Limestone and northern Great Plains regional aquifer system analysis projects, Montana, Nebraska, North Dakota, South Dakota, and Wyoming: U.S. Geological Survey Water-Resources Investigations 82-4107, 26 p.

Downey, J.S., Busby, J.F., and Dinwiddie, G.A., 1987, Regional aquifers and petroleum in the Williston Basin region of the United States, in Longman, W.W., ed., Williston Basin- 
Anatomy of a cratonic oil province: Rocky Mountain Association of Geologists, p. 299-312.

Durkee, E.F., 1953, Cambrian stratigraphy and paleontology of the east flank of the Bighom Mountains, Johnson and Sheridan Counties, Wyoming: Laramie, University of Wyoming, M.A. thesis, $85 \mathrm{p}$.

Eardley, A.J., 1962, Structural geology of North America (2nd ed.): New York, Harper and Row, 743 p.

Edie, R., 1958, Mississippian sedimentation and oil fields in southeastern Saskatchewan: American Association of Petroleum Geologists Bulletin, v. 42, p. 94-126.

Eisbacher, G.H., 1983, Devonian-Mississippian sinestral transcurrent faulting along the cratonic margin of western North America-A hypothesis: Geology, v. 11, no. 1, p. 7-10.

Erickson, H.D., 1954, Artesian conditions in east central South Dakota (iv): South Dakota Geological Survey Report of Investigations, 74, $116 \mathrm{p}$.

Flawn, P.T., 1961, Tectonics, in Flawn, P.R., and others, eds., The Ouachita system: Austin, University of Texas Bureau of Economic Geology Publication 6210, p. 162-173.

Flügel, Helmut, and Ziegler, Willi, 1957, Die Gliederung des Oberdevons und Unterkarbons am Steinberg westlich von Granz mit Conodonten: Naturwissenschaftlicher Verein füer Steiermark, Graz Mitteilungen, Granz, v. 87, p. 25-60.

Folk, R.L., 1959, Practical petrographic classification of limestone: American Association of Petroleum Geologists Bulletin, v. 43, p. 1-38.

Foster, D.I., 1958. Summary of the stratigraphy of the Minnelusa Formation, Powder River Basin, Wyoming, in Strickland, John, ed., Powder River Basin: Wyoming Geological Association Annual Field Conference Guidebook 13 , p. 39-44.

Foster, N.H., 1972, Ordovician System, in Mallory. W.W., ed., Geologic atlas of the Rocky Mountain region: Rocky Mountain Association of Geologists, p. 76-85.

Freyer, Günter, 1961, Zur Taxinomie un Biostratigraphie der Conodonten aus dem Oberdevon des Vogtlands unter besonderer Berucksichtigung des toV/VI: Freiberger Forschungshefte, v. 95, 96 p., 6 pls.

Fuller, J.G.C.M., 1961, Ordovician and contiguous formations in North Dakota, South Dakota, Montana, and adjoining areas in Canada and the United States: American Association of Petroleum Geologists Bulletin, v. 45, p. 1134-1363.

Gardner, L.S., 1959, Revision of Big Snowy Group in central Montana: American Association of Petroleum Geologists Bulletin, v. 43, no. 2, p. 329-349.

Gendzwill, D.J., and Wilson, N.L., 1987, Form and distribution of Winnipegosis mounds in Saskatchewan, in Longman, M.W., ed., Williston Basin-Anatomy of a cratonic oil province: Rocky Mountain Association of Geologists, p. 109-117.

Gerhard, L.C., Anderson, S.B., and Berg, J., 1978, Mission Canyon porosity development, Glenburn field, North Dakota. Williston Basin, in Estelle, Duane, and Miller, Roger, eds., The economic geology of the Williston Basin: Montana Geological Society Annual Conference, 24th, p. $177-188$.
Gibbs, F.K., 1972, Silurian System, in Mallory, W.W., ed., Geologic atlas of the Rocky Mountain region: Rocky Mountain Association of Geologists, p. 86-89.

Gilbert, M.C., 1983, Timing and chemistry of igneous events associated with the southern Oklahoma aulacogen: Tectonophysics, v. 94, p. 439-455.

Goddard, E.N., 1940, Manganese deposits at Phillipsberg, Granite County, Montana-A preliminary report: U.S. Geological Survey Bulletin 922-G, p. 157-240.

Graham, S.A., and Suttner, L.J., 1975, Occurrence of Cambrian islands in southwest Montana: The Mountain Geologist, v. 11, p. 71-84.

Gray, G.G., 1986, Native terranes of the central Klamath Mountains: Tectonics, v. 55, no. 7, p. 1043-1054.

Gray, H.H., 1972, Lithostratigraphy of the Maquoketa Group (Ordovician) in Indiana: Indiana Geological Survey Special Report 7, 28 p.

Grayston, L.D., Sherwin, D.F., and Allan, J.F., 1966, Middle Devonian, in McGrossan, R.G., and Glaister, R.R., eds. Geological history of western Canada (2nd ed.): Alberta Society of Petroleum Geologists, p. 49-59.

Grenda, J.C., 1978, Paleozoology of oil-well cores from the Tyler Formation (Pennsylvanian) in North Dakota, United States of America, in Estelle, Duane, and Miller, Roger, eds., The economic geology of the Williston Basin: Montana Geological Association Annual Conference, 24th, p. 249-260.

Gries, J.P., and Mickelson, J.C., 1964, Mississippian carbonate rocks in western South Dakota and adjoining areas, in Leskela, Willard, and others, eds., Third International Williston Basin Symposium Proceedings: Billings Geological Society, North Dakota Geological Society, and Saskatchewan Geological Society, p. 109-118.

Gries, J.P., and Tullis, E.L., 1955, The geologic history of the Black Hills, in Swartz, Joe, and others, eds., South Dakota Black Hills: North Dakota Geological Society Annual Field Conference Guidebook 3, p. 31-36.

Gries, Robbie, 1983, North-south compression of Rocky Mountain foreland structures, in Lowell, J.D., ed., Rocky Mountain foreland basins and uplifts: Rocky Mountain Association of Geologists, p. 9-32.

Gutschick, R.C., and Rodriguez, J., 1977, Late Devonian-Early Mississippian trace fossils and environments along the Cordilleran miogeocline, western U.S: Geological Journal Special Issue 9, p. 195-208.

1979. Biostratigraphy of the Pilot Shale (DevonianMississippian) and contemporaneous strata in Utah, Nevada, and Montana: Brigham Young University Geology Studies, v. 26 , no. 1, p. 37-63.

Hansen, A.R., 1966, Reef trends of Mississippian Ratcliffe zones, northeast Montana and northwest North Dakota: American Association of Petroleum Geologists Bulletin, v. 50, p. 2260-2268.

Hanson, A.M., 1952, Cambrian stratigraphy in southwestern Montana: Montana Bureau of Mines and Geology Memoir $33,46 \mathrm{p}$.

1957. Cambrian of Crazy Mountain Basin, in Graves, R.W., Jr., ed., Crazy Mountain Basin: Billings Geological Society Annual Field Conference Guidebook 8, p. 48. 
1962, Cambrian System in the Bighorn Canyon area, in Hansen, A.R., and McKeever, J.H., eds., Three Forks-Belt Mountains area-The Devonian system of Montana and adjacent areas: Billings Geological Society Annual Field Conference Guidebook 13, p. 51.

Harrison, J.E., 1972, Precambrian Belt Basin of northwest United States, its geometry, sedimentation, and copper resources: Geological Society of America Bulletin, v. 83, p. 1215-1240.

Harrison, J.E., Griggs, A.B., and Wells, J.D., 1974, Tectonic features of the Precambrian Belt Basin and their influence on post-Belt structures: U.S. Geological Survey Professional Paper 866, 15 p.

Heckel, P.H., 1972, Pennsylvanian stratigraphic reefs in Kansas, some modern comparisons and implications: Geologische Rundschau, v. 61, p. 584-598.

Hills, F.A., and Houston, R.S., 1979, Early Proterozoic tectonics of the central Rocky Mountains: University of Wyoming Contributions to Geology, v. 17, p. 89-110.

Hoffman, P.F., Dewey, J.F., and Burke. K., 1974, Aulacogens and their genetic relation to geosynclines, with a Proterozoic example from Great Slave Lake, Canada, in Dott, R.H., Jr., and Shaver, R.H., eds., Modern and ancient geosynclinal sedimentation: Society of Economic Paleontologists and Mineralogists Special Publication 19, p. 38-55.

Holden, G.S., and Fleckenstine, Martin, 1980, Geologic history of the Precambrian of the central Laramie Range, Wyoming, in Hollis, S., ed., Stratigraphy of Wyoming: Wyoming Geological Association Annual Field Conference Guidebook 31, p. 17-22.

Holland, F.D., Jr., 1952, Stratigraphic details of Lower Mississippian rocks of northeastern Utah and southwestern Montana: American Association of Petroleum Geologists Bulletin, v. 36, p. 1697-1734.

Holland, F.D., Jr., and others, 1987, Summary of the biostratigraphy of the Bakken Formation (Devonian and Mississippian) in the Williston Basin, North Dakota, in Carlson, C.G., and Christopher, J.E., eds., Fifth International Williston Basin Symposium Proceedings: Saskatchewan Geological Society Special Publication 9, p. 68-76.

Houlick, C.W., Jr., 1973, Interpretation of carbonate-detrital silicate transitions in the Carboniferous of western Wyoming: American Association of Petroleum Geologists Bulletin, v. 57, no. 3, p. 498-509.

Houston, R.S., 1969, Aspects of the geologic history of Wyoming related to the formation of uranium deposits, in Parker, R.B., ed., Wyoming uranium-Part I: University of Wyoming Contributions to Geology, v. 8, no. 2, p. 67-69.

Houston, R.S., ed., 1978, A regional study of rocks of Precambrian ages in that part of the Medicine Bow Mountains lying in southeastern Wyoming: Wyoming Geological Survey Memoir 1, 167 p.

Howell, B.F., Bridge, Joshia, Deiss, C.F., Edwards, Ira. Lochman, Christina, Raasch, G.O., and Resser, C.E., 1944, Correlation of the Cambrian formations of North America: Geological Society of America Bulletin, v. 55. p. 993-1003.
Howell, D.G., and Schermer, E.R., 1983, Terrane analysis and the evolution of North America: Geological Society of America Abstracts with Program, v. 15, no. 5, p. 429.

Hughes, R.V., 1933, The Geology of the Beartooth Mountain Front in Park County, Wyoming: National Academy of Science Proceedings, v. 19, no. 2, p. 239-253.

Hurley, G.W., 1962, Distribution and correlation of Upper Devonian formations, Sweetgrass arch area, northwestern Montana, in Hansen, A.R., and McKeever, J.H., eds., Three Forks-Belt Mountains area-The Devonian System of Montana and adjacent areas: Billings Geological Society Annual Field Conference Guidebook 13, p. 23-32.

Inden, R.F., and Moore, C.H., 1983, Beach environment, in Scholle, P.A., Bebout, D.G., and Moore, C.H., eds., Carbonate depositional environments: American Association of Petroleum Geologists Memoir 33, p. 211-265.

Ireland, H.A., 1966, Resume and setting of Middle and Upper Ordovician stratigraphy, Midcontinent and adjacent regions: Tulsa Geological Society Digest, v. 34, p. 26-40.

Irwin, M.L., 1965, General theory of epeiric clear water sedimentation: American Association of Petroleum Geologists Bulletin, v. 49, p. 445-459.

Irwin, W.P., 1977, Review of Paleozoic rocks of the Klamath Mountains, in Stewart, J.H., Stevens, C.H., and Fritsche, A.E., eds., Paleozoic paleogeography of the western United States: Pacific Section, Society of Economic Paleontologists and Mineralogists Pacific Coast Paleogeography Symposium 1.p. 441-454.

Jagger, T.A., 1904. General geology, in Irving, J.D., ed., Economic resources of the northern Black Hills, U.S.: U.S. Geological Survey Professional Paper 26, p. 7-41.

James, N.P., 1983, Reef environment, in Scholle, P.A., Bebout, D.G., and Moore, C.H., eds., Carbonate depositional environments: American Association of Petroleum Geologists Memoir 33, p. 345-440.

Jennings, J.B., 1987. Using capillary pressure techniques to map and identify an economic fairway in the Ordovician Red River on the western flank of the Williston Basin, in Carlson, C.G., and Christopher, J.E., eds., Fifth International Williston Basin Symposium Proceedings: Saskatchewan Geological Society Special Publication 9, p. 212-216.

Johnson, J.G., 1971, Timing and coordination of orogenic, epeiorogenic, and eustatic events: Geological Society of America Bulletin, v. 82, p. 3263-3298.

Keefer, W.R., and Van Lieu, J.A., 1966, Paleozoic formations in the Wind River Basin, Wyoming: U.S. Geological Survey Professional Paper 495-B, $60 \mathrm{p}$.

Kelley, Caswell, 1952, Geology of the Caballo Mountains: New Mexico University Publications in Geology 4, 286 p.

Kent, D.M., 1964, The geologic history of the Devonian System in the northern Great Plains, in Leskela, Willard, and others, eds., Third International Williston Basin Symposium Proceedings: Billings Geological Society, North Dakota Geological Society, and Saskatchewan Geological Society, p. 57-71.

1987, Paleotectonic controls on sedimentation in the northern Williston Basin, Saskatchewan, in Longman, W.M., ed., Williston Basin-Anatomy of a cratonic oil 
province: Rocky Mountain Association of Geologists, p. 157-170.

Kent, H.C., 1972, Review of Phanerozoic history, in Mallory, W.W., ed., Geologic atlas of the Rocky Mountain region: Rocky Mountain Association of Geologists, p. 57-59.

Kent, H.C., Couch, E.L., and Knepp, R.A., coordinators, 1988, Central and southern Rockies region, correlation of stratigraphic units of North America (COSUNA) project chart: American Association of Petroleum Geologist, 1 sheet.

Ketner, K.B., 1968, Origin of Ordovician quartzites in the Cordilleran miogeosyncline: U.S. Geological Survey Professional Paper 660-B, p. 169-177.

Kindell, E.M., 1908, Fauna and stratigraphy of the Jefferson Limestone in the northern Rocky Mountain region: Bulletin of American Paleontology, v. 4, 292 p.

Kirk, E., 1930, The Harding Sandstone of Colorado: American Journal of Science, v. 20. 5th ser., p. 456-466.

Klapper, Gilbert, 1966, Upper Devonian and Lower Mississippian conodont zones in Montana, Wyoming, and South Dakota: Kansas University Paleontology Contributions 3, 43 p.

Klapper, Gilbert, and Furnish, W.M., 1963, DevonianMississippian Englewood Formation in Black Hills, South Dakota: American Association of Petroleum Geologists Bulletin, v. 46, no. 11, p. 2071-2078.

Klepper, M.R., Weeks, R.A., and Ruppel, E.T., 1957, Geology of the southern Elkhorn Mountains, Jefferson and Broadwater Counties, Montana: U.S. Geological Survey Professional Paper 292, 82 p.

Kluth, C.F., 1986, Plate tectonics of the ancestral Rocky Mountains, in Peterson, J.A., ed., Plate tectonics and sedimentation in the Rocky Mountain region: Rocky Mountain Association of Geologists Memoir 41, p. 353-369.

Kluth, C.F., and Coney, P.J., 1981, Plate tectonics of the ancestral Rocky Mountains: Geology, v. 9, no. 1, p. 10-15.

Knechtel, M.M., 1956, Emerson Formation of Cambrian and probably Early Ordovician age in Little Rocky Mountains, Montana: American Association of Petroleum Geologists Bulletin, v. 40, no. 8, p. 1994-1995.

Knechtel, M.M., Brockunier, S.R., and Hobbs, S.W., 1944, Plains adjacent to the Little Rocky Mountains, northern Montana: U.S. Geological Survey Oil and Gas Investigations Preliminary Map 4, scale 1:48,000.

Knopf, A., 1963, Geology of the northern part of the Boulder batholith and adjacent areas, Montana: U.S. Geological Survey Miscellaneous Geologic Investigations Map I-381, scale $1: 48,000$.

Kohm, J.A., and Louden, R.O., 1978, Ordovician Red River of eastern Montana-western North Dakota-Relationship between lithofacies and production, in Estelle, Duane, and Miller, Roger, eds., The economic geology of the Williston Basin: Montana Geological Society Annual Conference 24, p. 99-117.

Lageson, D.R., Maughan, E.K., and Sando, W.J., 1979, The Mississippian and Pennsylvanian (Carboniferous) System in the United States-Wyoming: U.S. Geological Survey Professional Paper 1110-U, 38 p.

Larson, E.E., Patterson, P.E., Curtis, G., Drake, R., and Mutschler, F.E., 1985, Petrologic, paleomagnetic, and structural evidence of Palcozoic rift system in Oklahoma, New Mexico, Colorado, and Utah: Geological Society of America Bulletin, v. 96, p. 1364-1372.

Laudon, R.L., and Severson, J.L., 1953, New crinoid fauna, Mississippian, Lodgepole Formation, Montana: Journal of Paleontology, v. 27, no. 4, p. 505-536.

Lebauer, L.R., 1965, Genesis and environments of deposition of the Meagher Formation, Montana: Journal of Paleontology, v. 51, p. 73-101.

Lee, W., 1957, Stratigraphy and structural development of the Salina Basin area: Kansas State Geological Survey Bulletin $121,167 \mathrm{p}$.

LeFever, R.D., Thompson, S.C., and Anderson, S.B., 1987, Earliest Paleozoic history of the Williston Basin in North Dakota, in Carlson, C.G., and Christopher, J.E., eds., Fifth International Williston Basin Symposium Proceedings: Saskatchewan Geological Society Special Publication 9, p. 22-46.

Lewry, J.F., and Sibbald, T.I.I., 1980, Thermotectonic evolution of the Churchill province in northern Saskatchewan: Tectonophysics, v. 68, p. 45-82.

Lobdell, F.K., 1984. Age and depositional history of the Middle Devonian Ashern Formation in the Williston Basin, Saskatchewan, in Lorsong, J.A., and others, eds., Oil and gas in Saskatchewan: Saskatchewan Geological Society Special Publication 7, p. 5-12.

LoBue, Charles, 1982, Depositional environments and diagenesis of the Silurian Interlake Formation, Williston Basin, western North Dakota, in Christopher, J.E., and Kaldi, J., eds., Fourth International Williston Basin Symposium Proceedings: Saskatchewan Geological Society Special Publication 6, p. 29-42.

Lochman, Christina, 1950, Status of Dry Creek Shale of central Montana: American Association of Petroleum Geologists Bulletin, v. 34, no. 11, p. 2200-2222.

1957. Paleoecology of the Cambrian in Montana and Wyoming, in Ladd, H.S., ed., Paleoecology: Geological Society of America Memoir 67, p. 117-162.

Lochman, Christina, and Duncan, Donald, 1944, Early Upper Cambrian faunas of central Montana: Geological Society of America Special Paper 54, 181 p.

1950, The Lower Ordovician Bellefontia fauna in central Montana: Journal of Paleontology, v. 24, p. 350-353.

Lochman-Balk, Christina, 1955, Cambrian stratigraphy of the south and west margins of Green River Basin, in Anderman, G.G., ed., Green River Basin: Wyoming Geological Association Annual Field Conference Guidebook 10, p. 29-37.

1956, The Cambrian of the Rocky Mountains and southwest deserts of the United States and adjoining Sonora Province, Mexico, in Rodgers, John, ed., El Sistema Cambrico, su Paleogeografia y el Problema de su Base, Part 2: International Geological Congress, 20th, Tobajos, p. 529-560.

1960, The Cambrian section of western Wyoming, in McGookey, D.P., and Miller, D.N., Jr., eds., Overthrust belt of southwestern Wyoming and adjacent areas: Wyoming Geological Association Annual Field Conference Guidebook 15, p. 98-108. 
1971. The Cambrian of the craton of the United States, in Holland, C.H., ed., Cambrian of the New World: New York, John Wiley and Sons, p. 79-167.

1972, Cambrian System, in Mallory, W.W., ed., Geologic atlas of the Rocky Mountain region: Rocky Mountain Association of Geologists, p. 50-75.

Lochman-Balk, Christina, and Wilson, J.L., 1967, Stratigraphy of Upper Cambrian-Lower Ordovician subsurface sequence in Williston Basin: American Association of Petroleum Geologists Bulletin, v. 51, p. 883-917.

Longman, W.M., Gertal, T.G., and Glennie, J.S., 1983, Origin and geometry of Red River Dolomite reservoirs, western Williston Basin: American Association of Petroleum Geologists Bulletin, v. 67, p. 744-771.

Loreau, J.P., and Purser, B.H., 1973, Distribution and ultrastructure of Holocene ooids in the Persian Gulf, in Purser, B.H., ed., The Persian Gulf: New York, SpringerVerlag, p. 279-328.

Love, J.D., Denson, N.M., and Botinelli, Theodore, 1949, Geology of the Hartville uplift, eastern Wyoming: U.S. Geological Survey Oil and Gas Investigations Preliminary Map 102, 2 sheets.

Love, J.D., Henbest, L.G., and Denson, N.M., 1953, Stratigraphy and paleontology of Paleozoic rocks, Hartville area, eastern Wyoming: U.S. Geological Survey Oil and Gas Investigations Chart OC-44, 2 sheets.

Macauley, G., Penner, D.G., Proctor, R.M., and Tisdall, W.H., 1966, Carboniferous, in McCrossan, R.G., and Glanister, R.P., eds., Geological history of western Canada: Alberta Society of Petroleum Geologists, p. 89-102.

MacCary, L.M., 1981. Apparent water resistivity, porosity, and groundwater temperature of the Madison Limestone and underlying rocks in parts of Montana. Nebraska, North Dakota, South Dakota, and Wyoming: U.S. Geological Survey Open-File Report 81-629, 36 p.

Macqueen, R.W., and Sandberg, C.A., 1970, Stratigraphy, age. and interregional correlation of the Exshaw Formation, Alberta Rocky Mountains: Canadian Petroleum Geology Bulletin, v. 18, no. 1, p. 32-66.

Magathan, E.R., 1987, Silurian Interlake Group-A sequence of cyclic marine and freshwater carbonate deposits in central Williston Basin, in Fischer. D.W., ed., Fifth International Williston Basin Symposium Core Workshop volume: North Dakota Geological Survey Miscellaneous Series 69, p. 59-88.

Mallory, W.W, 1967, Pennsylvanian and associated rocks in Wyoming: U.S. Geological Survey Professional Paper 554-G, 31 p.

1972, Regional synthesis of the Pennsylvanian System, in Mallory, W.W., ed., Geologic atlas of the Rocky Mountain region: Rocky Mountain Association of Geologists, p. 111-127.

1975, Middle and Southern Rocky Mountains, northern Colorado Plateau, and eastern Great Basin region, in McKee, E.D., and Crosby, E.J., eds., Paleotectonic investigations of the Pennsylvanian System in the United States: U.S. Geological Survey Professional Paper 853, p. 265-278.

Martin, D.W., Fischer, H.J., Keogh, R.J., and Moore, K., 1980 , The petrology of the limestones in the upper Gros Ventre and Gallatin Limestone Formations (Middle and Upper Cambrian) northwestern Wind River Basin, Wyoming, in Harrison, Avis, ed., Stratigraphy of Wyoming: Wyoming Geological Association Annual Field Conference Guidebook 31, p. 37-51.

Maughan, E.K., 1963, Mississippian rocks in the Laramie Range, Wyoming, and adjacent areas: U.S. Geological Survey Professional Paper 475-C, p. 23-27.

1983, Tectonic setting of the Rocky Mountain region during the late Paleozoic and early Mesozoic, in Ranta, D.E., Kamili, R.J., and Pansze, A.J., eds., Proceedings of the Symposium on the Genesis of Rocky Mountain Ore Deposits-Changes with Time and Tectonics: Denver Regional Exploration Geologists Society, p. 39-50.

1984, Paleogeographic setting of Pennsylvanian Tyler Formation and relation to underlying Mississippian rocks in Montana and North Dakota: American Association of Petroleum Geologists Bulletin, v. 68, no. 2, p. 178-195.

Maughan, E.K., and Perry, W.J., Jr., 1986, Lineaments and their tectonic implications in the Rocky Mountain and adjacent plains region, in Peterson, J.A., ed., Paleotectonics and sedimentation in the Rocky Mountain region: American Association of Petroleum Geologists Memoir 41, p. 41-53.

Maughan, E.K., and Roberts, A.E., 1967, Big Snowy and Amsden Groups and Mississippian-Pennsylvanian boundary in Montana: U.S. Geological Survey Professional Paper 554-B. 27 p.

McCabe, H.R., and Barchyn, D., 1982, Paleozoic stratigraphy of southwestern Manitoba: Geological Association of Canada-Mineralogical Association of Canada Joint Annual Meeting Field Trip Guidebook 10, 42 p.

McCoy, M.R., 1952, Ordovician sediments in the northern Black Hills, in Sonnenberg, F.P., ed., Black Hills-Williston Basin Symposium: Billings Geological Society Annual Field Conference Guidebook 3, p. 44-47.

McMannis, W.J., 1962, Devonian stratigraphy between Three Forks, Montana, and Yellowstone Park, in Hansen, A.R., and McKeever, J.H., eds., Three Forks-Belt Mountains area-The Devonian System of Montana and adjacent areas: Billings Geological Society Annual Field Conference Guidebook 13, p. 4-12.

McMillen, K.J., 1989, Cambrian seismic stratigraphy and extensional tectonics of the Powder River Basin, Wyoming: Geological Society of America Abstracts with Program, v. 25 , no. 5 , p. 116 .

Meissner, F.F., 1978, Petroleum geology of the Bakken Formation, Williston Basin, North Dakota and Montana, in Estelle, Duane, and Miller, Roger, eds., The economic geology of the Williston Basin: Montana Geological Society Annual Conference, 24th, p. 17-31.

Meissner, F.F., Woodward, Jane, and Clayton, J.L., 1984, Stratigraphic relationships and distribution of source rocks in the greater Rocky Mountain region, in Woodward, Jane, Meissner, F.F., and Clayton, J.L., eds., Hydrocarbon source rocks of the greater Rocky Mountain region: Rocky Mountain Association of Geologists, p. 1-34.

Merguerian, Charles, and Schweickert, R.A., 1987, Paleozoic gneissic granitoids in the Shoo Fly Complex, central Sierra Nevada, California: Geological Society of America Bulletin, v. 99, no. 5. p. 699-717. 
Metzger, R.A., 1989, Upper Devonian (Frasnian-Famennian) conodont biostratigraphy in the subsurface of north-central Iowa and southern Nebraska: Journal of Paleontology, v. 63 no. 4 , p. 504-524.

Meyerhoff, H.A., and Lochman, Christina, 1934, Crepicephalus horizon in the Deadwood Formation of South Dakota [abs.]: Geological Society of America Proceedings for 1933, p. 99.

1935. Faunal zones in the Deadwood Formation of South Dakota [abs.]: Geological Society of America Proceedings for 1934, p. 352-353.

1936, Deadwood faunas in South Dakota and eastern Wyoming: Geological Society of America Proceedings for 1935 , p. 386.

Mickelson, J.C., and Kulik, J.W., 1963, Pre-Minnelusa stratigraphy of the Northern Black Hills, in Cooper, G.G., Cardinal, D.F., Lorenz, H.W., and Lynn, J.R., eds., Northern Powder River Basin, Wyoming and Montana: Wyoming Geological Society and Billings Geological Society Joint Field Conference Guidebook 1, p. 41-44.

Middleton, L.T., Steidtmann, J.R., and DeBour, D.A., 1980, Stratigraphy and depositional setting of some Middle and Upper Cambrian rocks, Wyoming, in Harrison, Avis, ed., Stratigraphy of Wyoming: Wyoming Geological Association Annual Field Conference Guidebook 31 . p. 23-35.

Miller, A.K., 1930, The age and correlation of the Bighorn Formation of northwestern United States: American Journal of Science, v. 20. 5th ser., p. 195-213.

Miller, B.M., 1935, Cambrian stratigraphy of northwestern Wyoming [abs.]: Geological Society of America Proceedings for 1934, p. 352.

1936, Cambrian stratigraphy of north-western Wyoming: Journal of Geology, v. 44, p. 113-144.

Morris, R.C., 1974, Sedimentary and tectonic history of the Ouachita Mountains, in Dickinson, W.R., ed., Tectonics and sedimentation: Society of Economic Paleontologists and Mineralogists Special Publication 22, p. 120-142.

Mundt, P.A., 1956, Heath-Amsden strata in central Montana: American Association of Petroleum Geologists Bulletin, v. 40, no. 5, p. 1915-1934.

Murphy, J.B., and Nance, R.D., 1989, Model for the evolution of the Avalonian-Cadomian blet: Geology, v. 17, no. 8, p. 735-738.

Nelson, B.K., and DePaolo. D.J., 1985. Rapid production of continental crust 1.7 to 1.9 b.y. ago- $\mathrm{Nd}$ isotopic evidence from the basement of North American Mid-continent: Geological Society of America Bulletin, v. 96. p. 746-754.

Nelson, V.E., and Church, Victor, 1943, Critical structures of the Gros Ventre and northern Hoback Ranges, Wyoming: Journal of Geology, v. 51, no. 3, p. 143-166.

Nordquist, J.W., 1953, Mississippian stratigraphy of northern Montana, in Parker, J.M., ed., Little Rocky Mountains-Montana, southern Saskatchewan: Billings Geological Society Annual Field Conference Guidebook 4, p. $68-82$.

Norwood, E.E., 1965, Geological history of central and southcentral Montana: American Association of Petroleum Geologists Bulletin, v. 49, no. 11, p. 1824-1832.
O'Neil, J.M., and Lopez, D.A., 1985, Character and regional significance of Great Falls tectonic zone, east-central Idaho and west-central Montana: American Association of Petroleum Geologists Bulletin, v. 69, p. 437-447.

Osmond, J.C., 1962, Stratigraphy of Devonian Sevey Dolomite in Utah and Nevada: American Association of Petroleum Geologists Bulletin, v. 26, no. 1, p. 32-41.

Palmer, A.R., 1971, The Cambrian of the Great Basin and adjacent areas, western United States, in Holland, C.H., ed., Lower Paleozoic rocks of the world: London, WileyInterscience, v. 1, p. 1-78.

Palmer, A.R., and Halley, R.B., 1979, Physical stratigraphy and trilobite biostratigraphy of the Carrara Formation (Lower and Middle Cambrian) in the southern Great Basin: U.S. Geological Survey Professional Paper 1047, 131 p.

Palonen, P.A., 1976, Sedimentology and stratigraphy of Gog Group sandstones in southern Canadian Rockies: University of Calgary, Ph.D. thesis.

Parkinson, C.R., 1958, The Flathead Formation (Middle Cambrian) of the northwestern Wind River Mountains, Wyoming: Oxford, Ohio, Miami University, M.S. thesis, $106 \mathrm{p}$.

Patterson, J.R., 1961, Ordovician stratigraphy and correlations in North America: American Association of Petroleum Geologists Bulletin, v. 45, p. 1364-1377.

Paull, R.A., and Gruber, D. P., 1977, Little Copper FormationNew name for lowest formation of Mississippian Copper Basin Group, Pioneer Mountains, south-central Idaho: America Association of Petroleum Geologists Bulletin 61. no. 2, p. $256-262$.

Peal, A.C., 1893, The Paleozoic section in the vicinity of Three Forks, Montana: U.S. Geological Survey Bulletin 110, $56 \mathrm{p}$.

Peterson, J.A., 1966, Sedimentary history of the Sweetgrass arch, in Cox, J.E., ed., Jurassic and Cretaceous stratigraphic traps-Sweetgrass arch: Billings Geological Society Annual Field Conference and Symposium 17. p. 112-113. 1978, Subsurface geology and porosity distribution, Madison Limestone and underlying formations, Powder River Basin, northeastern Wyoming and southeastern Montana: U.S. Geological Survey Open-File Report 78-189, 9 p.

1980a, Depositional history and petroleum geology of the Permian Phosphoria and Park City Formations, Wyoming and southeastern Idaho: U.S. Geological Survey Open-File Report 80-667, 42 p.

1980b, Permian paleogeography and sedimentary provinces, west-central United States, in Fouch, T.D., and Magathan, E.R., eds., Symposium on Paleozoic paleogeography of west-central United States: Rocky Mountain Section, Society of Economic Paleontologists and Mineralogists West-Central United States Paleogeography Symposium 1, p. 271-292.

1984, Stratigraphy and sedimentary facies of the Madison Limestone and associated rocks in parts of Montana, Nebraska, North Dakota. South Dakota, and Wyoming: U.S. Geological Survey Professional Paper 1273-A, 34 p. 1985. Regional stratigraphy and general petroleum geology of Montana and adjacent areas, in Tonnson, J.J., ed., 
Montana oil and gas fields symposium, 1985: Montana Geological Society, v. 1, p. 5-45.

Peterson, J.A., and MacCary, L.M., 1987, Regional stratigraphy and general petroleum geology of the U.S. portion of the Williston Basin and adjacent area, in Peterson, J.A., Kent, D.M., Anderson, S.B., Pilatzke, R.H., and Longman, M.W., eds., Williston Basin-Anatomy of a cratonic oil province: Rocky Mountain Association of Geologists, p. 9-43.

Poole, F.G., 1974, Flysch deposits of the Antler foreland basin, western United States, in Dickinson, W.R., ed., Tectonics and sedimentation: Society of Economic Paleontologists and Mineralogists Special Publication 22, p. 58-82.

Porter, J.W., and Fuller, J.G.C.M., 1958, Succession of Lower Paleozoic rocks in the northern part of the Williston Basin, in Cumming, A.D., ed., Second Williston Basin Symposium Proceedings: Saskatchewan Geological Society and North Dakota Geological Society, p. 33-39.

1959, Lower Paleozoic rocks of northern Williston Basin and adjacent areas: American Association of Petroleum Geologists Bulletin, v. 43, no. 1, p. 124-189.

1964, Ordovician-Silurian, in McGrossan, R.G., and Glaister, R.D., eds., Geologic history of western Canada (1st ed.): Alberta Society of Petroleum Geologists, p. 32-42.

Porter, J.W., Fuller, J.G.C.M., and Norford. B.S., 1966, Ordovician-Silurian, in McGrossan, R.G., and Glaister. R.P., eds., Geological history of western Canada (2nd ed.): Alberta Society of Petroleum Geologists, p. 34-48.

Pugh, D.C., 1971, Subsurface Cambrian stratigraphy in southern and central Alberta: Geological Society of Canada Paper 70-10, $33 \mathrm{p}$.

Purser, B.H., and Evans, G., 1973, Regional sedimentation along the Trucial Coast, S.E. Persian Gulf, in Purser, B.H., ed. The Persian Gulf: New York, Springer-Verlag, p. 211-231.

Randal, A.G., 1963, Catalog of formation names for northern Powder River Basin, Wyoming and Montana. in Cooper, G.G., Cardinal, D.F., Lorenz, H.W., and Lynn, J.R., eds., Northern Powder River Basin, Wyoming and Montana: Wyoming Geological Association and Billings Geological Society Joint Field Conference Guidebook 1, p. 169-179.

Read, J.F., 1985, Carbonate platform facies models: American Association of Petroleum Geologists Bulletin, v. 69, no. 1 , p. 1-21.

Rhodes, F.H.T., Austin, R.L., and Druce, E.C., 1969, British Avonian (Carboniferous) conodont faunas and their value in local and intercontinental correlation: British Museum Natural History Bulletin Geology Supplement 5, 313 p.

Richards, P.W., 1957, Geology of the area east of and southeast of Livingston, Park County, Montana: U.S. Geological Survey Professional Paper 1021-L, p. 385-438.

Roberts, A.E., 1979, Northern Rocky Mountains and adjacent plains region, in Craig, L.C., and Connor, C.W., coordinators, Paleotectonic investigations of the Mississippian System-Part I, Introduction and regional analysis of the Mississippian System: U.S. Geological Survey Professional Paper 526-B, p. B1-B23.

Roberts, R.J., 1951, Geologic map of the Antler Peak quadrangle, Nevada: U.S. Geological Survey Geologic Quadrangle Map GQ-10, scale 1:62,000.
Roberts, R.J., Hotz, P.E.. Gilluly, James, and Ferguson, H.G., 1958, Paleozoic rocks of north-central Nevada: American Association of Petroleum Geologists Bulletin, v. 42, p. 2813-2857.

Robinson, G.D., and Barnett, H.F., 1963, Geology of the Three Forks quadrangle, Montana: U.S. Geological Survey Professional Paper 370, $47 \mathrm{p}$.

Roehl, P.O., 1967, Stony Mountain (Ordovician) and Interlake (Silurian) facies analogs of recent low energy marine and subaerial carbonates, Bahamas: American Association of Petroleum Geologists Bulletin, v. 51, p. 1979-2032.

Rose, P.R., 1976, Mississippian carbonate shelf margins, western U.S: U.S. Geological Survey Journal of Research, v. 4, p. $449-466$.

Rosenthal, L.R., 1987, The Winnipegosis Formation of the northeastern margin of the Williston Basin, in Carlson, C.G., and Christopher, J.E., eds., Fifth International Williston Basin Symposium Proceedings: Saskatchewan Geological Society Special Publication 9, p. 37-46.

Ross, R.J., Jr., 1951, Stratigraphy of the Garden City Formation in northeastern Utah and its trilobite faunas: Peabody Museum Natural History Bulletin, 6, $161 \mathrm{p}$.

1957, Ordovician fossils from wells in the Williston Basin eastern Montana: U.S. Geological Survey Bulletin 1021-M, p. 439-510.

1976. Ordovician sedimentation in the western United States, in Bassett, M.G., ed., The Ordovician System-Proceeding of a Paleontological Association Symposium: Cardiff, University of Wales Press, p. 73-105. 1977. Ordovician paleogeography of the western United States, in Stewart, J.H., Stevens, C.H., and Ritsche, A.E., eds., Paleozoic paleogeography of the western United States: Pacific Coast Section, Society of Economic Paleontologists and Mineralogists, p. 19-38.

Ross, R.J., Jr., Adler, F.J., Amsden, T.W., Bergstrom, Douglas, Bergstrom, S.M., Carter, Claire, Churkin, Michael, Cressman, E.A., Derby, J.R., Dutro, J.T., Jr., Ethington, R.L., Finney, S.C., Fisher, D.W., Fisher, J.H., Harris, A.G., Hintz, L.F., Ketner, K.B., Kolata, D.L., Landing, Ed, Neuman, R.B., Sweet, W.C., Pojeta, John, Jr., Potter, A.W., Rader, E.K., Repetski, J.E., Shaver, R.H., Thompson, T.L., and Webers, G.F., 1982, The Ordovician System in the United States: International Union of Geological Sciences Publication 12, 73 p.

Ross, R.J., Jr., and Cornwall, H.R., 1961, Bioherms in the upper part of the Pogonip in southern Nevada: U.S. Geological Survey Professional Paper 424-B, p. 2331-2333.

Rowley, D.B., and Kidd, W.S., 1981, Stratigraphic relationships and detrital composition of the medial Ordovician flysch of western New England-Implications for the tectonic evolution of the Taconic orogeny: Journal of Geology, v. 89, no. 2, p. 199-218.

Sandberg, C.A., 1961a, Distribution and thickness of Devonian rocks in Williston Basin and in central Montana and northcentral Wyoming: U.S. Geological Survey Bulletin 1112-D, p. 105-127.

1961b, Widespread Beartooth Butte Formation of Early Devonian age in Montana and Wyoming and its paleogeographic significance: American Association of Petroleum Geologists Bulletin, v. 45, no. 8, p. 1301-1309. 
1962, Stratigraphic sections of type Three Forks and Jefferson Formations at Logan, Montana, in Hansen, A.R., and McKeever, J.H., eds., Three Forks-Belt Mountains area-The Devonian System in Montana and adjacent areas: Billings Geological Society Annual Field Conference Guidebook 13, p. 47-50.

1963, Dark shale unit of Devonian and Mississippian age in northern Wyoming and southern Montana: U.S. Geological Survey Professional Paper 475-C, p. C17-C20.

1965, Nomenclature and correlation of lithologic subdivisions of the Jefferson and Three Forks Formations of southern Montana and northern Wyoming: U.S. Geological Survey Bulletin 1194-N, 18 p.

1967, Measured sections of Devonian rocks in northern Wyoming: Geological Survey of Wyoming Bulletin 52 , $93 \mathrm{p}$.

1976, Conodont biofacies of Late Devonian Polygnathus styriacus Zone in western United States, in Barnes, C.R., ed., Conodont paleoecology: Geological Association of Canada Special Paper 15, p. 171-186.

Sandberg, C.A., and Gutschick, R.C., 1969, Stratigraphy and conodont zonations of the type Leatham Formation (Devonian and Mississippian), Bear River Range, Utah: Geological Society of America Abstracts with Program, p. 70-71.

Sandberg, C.A., and Hammond, C.R., 1958, Devonian System in Williston Basin and central Montana: American Association of Petroleum Geologists Bulletin, v. 42, no. 10, p. 2293-2344.

Sandberg, C.A., and Klapper, Gilbert, 1967, Stratigraphy, age, and paleotectonic significance of the Cottonwood Canyon Member of the Madison Limestone in Wyoming and Montana: U.S. Geological Survey Bulletin 1251-B, 70 p.

Sandberg, C.A., and Mapel, W.J., 1967, Devonian of the northern Rocky Mountain Plains, in Oswald, D.H., ed., International Symposium on the Devonian System: Alberta Society of Petroleum Geologists, v. 1, p. 843-887.

Sandberg, C.A., and Ziegler, Willi, 1979, Taxonomy and biofacies of important conodonts of Late Devonian styriacus-Zone, United States and Germany: Geologica et Paleontologica, v. 13, p. 173-212.

Sando, W.J., 1967, Mississippian depositional provinces in the northern Cordilleran region: U.S. Geological Survey Professional Paper 575-D, p. D29-D38.

1974, Ancient solution phenomena in the Madison Limestone (Mississippian) of north-central Wyoming: U.S. Geological Survey Journal of Research, v. 2, no. 2, p. 133-141.

1975, Stratigraphic sections of the Madison Limestone and Amsden Formations, west flank of the Bighorn Basin, Wyoming, in Exum, F.A., and George, G.R., eds., Geology and mineral resources of the Bighorn Basin: Wyoming Geological Association Annual Field Conference Guidebook 27, p. 129-137.

1976a, Madison Limestone (Devonian and Mississippian), east flank of Bighorn Mountains, Wyoming, in Laudon, R.B., ed., Geology and energy resources of the Powder River Basin: Wyoming Geological Association Annual Field Conference Guidebook 28, p. 45-52. 1976b, Mississippian history of the northern Rocky Mountains region: U.S. Geological Survey Journal of Research, v. 4, no. 3, p. 317-338.

1978, Coral zones and problems of Mississippian stratigraphy in the Williston Basin, in Estelle, Duane, and Miller, Roger, eds., The economic geology of the Williston Basin: Montana Geological Society Annual Conference, 24th, p. 231-238.

Sando, W.J., and Mamet, B.L., 1974, New evidence on the age of the top of the Madison Limestone, Bighorn Mountains, Wyoming and Montana: U.S. Geological Survey Journal of Research, v. 2, p. 619-624.

Sando, W.J., and Sandberg, C.A., 1987, New interpretations of Paleozoic stratigraphy and history in the northern Laramie Range and vicinity, southeast Wyoming: U.S. Geological Survey Professional Paper 1450, 39 p.

Sando, W.J., Sandberg, C.A., and Perry, W.J., 1985, Revision of Mississippian stratigraphy, northern Tendoy Mountains, southwest Montana: U.S. Geological Survey Bulletin 1656-A, 24 p.

Sannemann, Dietrich, 1955, Beitrag zur Untergliederung des Oberdevons nach Conodonten: Neues Jahrbuch fur Geologie und Paläeontologie, Abhandlungen, Schweizerbart, v. 100, p. 324-331.

Scholle, P.A., Debout, D.G., and Moore, C.H., eds., 1983, Carbonate depositional environments: American Association of Petroleum Geologists Memoir 33, 708 p.

Schriel, Walter, and Stoppel, Dieter, 1960, Die Einstufung des Tanner Grauwakensystems im Harz auf Grund von Conodonten: Seitschrift der Deutschen Geologischen Gesellschaft, v. 111, p. 663-683.

Scott, H.W., 1935, Some Carboniferous stratigraphy in Montana and northwestern Wyoming: Journal of Geology, v. 43, no. 8, p. 1011-1032.

Seager, O.A., 1942, Test on Cedar Creek anticline, southwest Montana: American Association of Petroleum Geologists Bulletin, v. 26, p. 861-864.

Shaw, A.B., 1954, Correlation of Paleozoic formations of Wyoming, chart 2, in Richards, P.W., ed., Pryor Mountains-northern Bighorn Basin: Billings Geological Association Annual Field Conference Guidebook 5, p. 24.

1957. Cambrian of southwestern Wind River Basin, Wyoming, in Bibb, T.W., Jr., ed.. Southwest Wind River Basin: Wyoming Geological Association Annual Field Conference Guidebook 12, p. 9-16.

Shaw, A.B., and DeLand, C.R., 1955, Cambrian of southwestern Wyoming, in Anderman, G.G., ed., Green River Basin: Wyoming Geological Association Annual Field Conference Guidebook 10, p. 38-42.

Shaw, A.B., and McGrew, P.O., 1954, Correlation chart 2, in Olson, W.G., ed., Casper area, Wyoming: Wyoming Geological Association Annual Field Conference Guidebook 9.

Sheldon, R.P., and Carter, M.D., 1979, Williston Basin region, in Craig. L.C., and Connor, C.W., coordinators, Paleotectonic investigations of the Mississippian System in the United States-Part I, Introduction and regional analysis of the Mississippian System: U.S. Geological Survey Professional Paper 1010, p. 249-272. 
Slack, P.B., 1981, Paleotectonics and hydrocarbon accumulations, Powder River Basin, Wyoming: American Association of Petroleum Geologists Bulletin, v. 65, p. 730-743.

Sloss, L.L., 1952, Introduction to the Mississippian of the Williston Basin, in Sonnenberg, F.P., ed., Black Hills-Williston Basin Symposium: Billings Geological Society Annual Field Conference Guidebook 3, p. 65-69.

Sloss, L.L., and Hamblin, R.H., 1942. Stratigraphy and insoluble residues of Madison Group (Mississippian), Montana: American Association of Petroleum Geologists Bulletin, v. 26, no. 3, p. 305-335.

Sloss, L.L., and Laird, W.M., 1947, Devonian System in central and northwestern Montana: American Association of Petroleum Geologists Bulletin, v. 31, p. 1404-1430.

Sloss, L.L., and Moritz, C.A., 1951, Paleozoic stratigraphy of southwestern Montana: American Association of Petroleum Geologists Bulletin, v. 35, no. 10, p. 2135-2169.

Smith, A.G., Hurley, A.M., and Briden, J.C., 1981, Phanerozoic paleocontinental world maps: New York, Cambridge University Press, 102 p.

Smith, D.L., 1972, Depositional cycles of the Lodgepole Formation (Mississippian) in central Montana, in Lynn, R.J., ed., Crazy Mountains Basin: Montana Geological Society Annual Field Conference Guidebook 21, p. 29-35.

Smith, D.L., and Gilmour, E.H., 1979, The Mississippian and Pennsylvanian (Carboniferous) Systems in the United States-Montana: U.S. Geological Survey Professional Paper 1110-X, p. X1-X31.

Speed, R.C., and Sleep, N.H., 1982, Antler orogeny and foreland basin-A model: Geological Society of America Bulletin, v. 93, no. 9, p. 815-828.

Spencer, Carl, Green, Allen, Morel á l'Huissier, Patrick, Luetgert, James, Stewart, David, Unger, John, and Phillips, Jeffery, 1989. The extension of Grenville basement beneath the northern Appalachians-Results from the Quebec-Maine seismic reflection and refraction surveys: Tectonics, v. 8, no. 4 , p. 667-696.

Stearns, C.W., 1953, Ordovician-Silurian boundary in Manitoba [abs.]: Geological Society of America Bulletin, v. 64, p. 1477-1478.

1956, Stratigraphy and paleontology of the Interlake Group and Stonewall Formation in southern Manitoba: Canada Geological Survey Memoir 281, 162 p.

Stewart, J.H., 1976, Late Precambrian evolution of North America-Plate tectonic implications: Geology, v. 4, no. 1, p. 11-15.

Stewart, J.H., and Suczek, C.A., 1977. Cambrian and latest Precambrian paleogeography and tectonics in the western United States, in Stewart, J.H., Stevens, C.H., and Fritsche, A.E., eds., Paleozoic paleogeography of the western United States: Pacific Coast Section. Society of Economic Paleontologists and Mineralogists Paleogeography Symposium 1, p. 1-18.

Stone, R.A., 1972, Waulsortian-type bioherms (reefs) of Mississippian age, central Bridger Range, Montana, in Lynn, J.R., ed., Crazy Mountains Basin: Montana Geological Society Annual Field Conference Guidebook 21, p. 37-55.

Stoppel, Dieter, 1958, Das Oberdevon un Unterkarbon im südlichen Kellerwald: Notizblatt des Hessischen
Landesamtes füer Bodenforschung, Wiesbaden, v. 87 , p. 89-119.

Strainbrook, M.A., 1947, Grachiopoda of the Perch Shale of New Mexico and Arizona: Journal of Paleontology, v. 21(4), p. 241-244.

1950, The fauna and correlation of the McCraney Limestone in Iowa and Illinois: American Journal of Science, v. 248, p. 194-213.

Swartz, C.K., Alcock, F.J., Butts, Charles, Chadwick, G.H., Cumings, E.R., Decker, C.E., Ehlers, G.M., Foerste, A.F., Gillette, T., Kindle, E.M., Kirk, Edwin, Northrop, S.A., Prouty, W.F., Savage, T.E., Shrock, R.R., Swartz, F.M., Twenhofel, W.H., and Williams, M.Y., 1942, Correlation of the Silurian formations of North America-Correlation chart 3: Geological Society of America Bulletin, v. 53, p. 533-538.

Sweet, W.C., 1955, Harding and Fremont Formations, Colorado: American Association of Petroleum Geologists Bulletin, v. 38, p. 284-305.

Sweet, W.C., and Bergström, S.M., 1976, Conodont biostratigraphy of the Middle and Upper Ordovician of the United States Midcontinent, in Bassett, M.B., ed., The Ordovician System-Proceedings of a Paleontological Association Symposium: Cardiff, University of Wales Press and National Museum of Wales, p. 121-151.

Sweet, W.C., Ethington, R.L., and Baars, C.R., 1971, North American Middle and Upper Ordovician conodont faunas, in Sweet, W.C., and Bergström, S.M., eds., Symposium on Conodont Biostratigraphy: Geological Society of America Memoir 127, p. 163-193.

Templemen-Kluit, D.J., 1979, Transported cataclastite, ophiolite, and granodiorite in Yukon-Evidence of arc-continent collision: Canada Geological Survey Paper 79-14, 27 p.

Templeton, J.S., and Williams, H.B., 1963, Champlainian Series (Middle Ordovician) in Illinois: Illinois State Geological Survey Bulletin 89,260 p.

Tenney, C.S., 1966, Pennsylvanian and Lower Permian deposition in Wyoming and adjacent areas: American Association of Petroleum Geologists Bulletin, v. 50, no. 2, p. 227-250.

Thomas, H.D., 1951, Summary of Paleozoic stratigraphy of the region about Rawlins, south-central Wyoming, in Brinker, W.F., and Blackstone, D.L., Jr., eds., South-central Wyoming: Wyoming Geological Association Annual Field Conference Guidebook 6, p. 32-36.

Thomas, L.A., 1949, Devonian-Mississippian formations of southeast Iowa: Geological Society of America Bulletin, v. 60 , p. 403-438.

Thrasher, L.C., 1987, Microfossils and stratigraphic subdivisions of the Bakken Formation (Devonian-Mississippian), Williston Basin, North Dakota, in Carlson, C.G., and Christopher, J.E., eds., Fifth International Williston Basin Symposium Proceedings: Saskatchewan Geological Society Special Publication 9, p. 53-67.

Tomlinson, C.W., 1917, The middle Paleozoic stratigraphy of the central Rocky Mountain region: Journal of Geology, v. 25, p. 112-134, 244-257, 373-394.

Tonnsen, J.J., 1986, Influence of tectonic terranes adjacent to the Precambrian Wyoming province on Phanerozoic stratigraphy in the Rocky Mountain region, in Peterson, J.A., ed., Paleotectonics and sedimentation in the Rocky 
Mountain region: American Association of Petroleum Geologists Memoir 41, p. 21-39.

Trexler, J.H., Jr., and Nitchman, S.P., 1990, Sequence stratigraphy and evolution of the Antler foreland basin, east-central Nevada: Geology, v. 18, no. 5, p. 422-425.

Vail, P.R., Mitchum, R.M., and Thompson, S., 1977, Seismic stratigraphy and global changes of sea level, Part 4 -Global cycles of relative changes of sea level, in Payton, C.E., ed., Seismic stratigraphy-Applications to hydrocarbon exploration: American Association of Petroleum Geologists Memoir 26, p. 83-97.

Van Eysinga, F.W.B., 1978, Geologic time table (3rd ed.): Amsterdam, Elsevier, 1 sheet.

Veil, G.S., 1979, Geologic map and cross section, eastern Ouachita Mountains, Arkansas: Geological Society of America Bulletin, v. 90, no. 12, p. 1096-1099.

Vigrass, L.W., 1977, Depositional framework of the Winnipeg Formation in Manitoba and eastern Saskatchewan: Geological Association of Canada Special Paper 9, p. 225-234.

Wanless, H.R., Belknap, R.L., and Foster, H.L., 1955, Paleozoic and Mesozoic rocks of Gros Ventre, Teton, Hoback, and Snake River Ranges, Wyoming: Geological Society of America Memoir 63, 90 p.

Webster, R.L., 1987, Petroleum source rocks and stratigraphy of the Bakken Formation in North Dakota, in Longman, M.W., ed., Williston Basin-Anatomy of a cratonic oil province: Rocky Mountain Association of Geologists, p. 269-285.

Weed, W.H., 1899a, Description of Little Belt Mountains quadrangle: U.S. Geological Survey Geologic Atlas Folio 56.9 p.

$1899 \mathrm{~b}$, Description of the Fort Benton quadrangle: U.S. Geological Survey Geologic Atlas Folio 55, 7 p.

1900, Geology of the Little Belt Mountains, Montana: U.S. Geological Survey 20th Annual Report, part 3, p. 257-461.

Williams, Harold, and Hatcher, R.D., Jr., 1982, Suspect terranes and accretionary history of the Appalachian orogen: Geology, v. 10, no. 10 , p. 530-536.

Williams, J.S., 1948, Geology of the Paleozoic rocks, Logan quadrangle, Utah: Geological Society of America Bulletin, v. 59, no. 11. p. 1121-1163.

1955, Resume of Paleozoic stratigraphy, Ordovician to Pennsylvanian of the Green River Basin area, Wyoming, in Anderman, G.G., ed., Green River Basin: Wyoming Geological Association Annual Field Conference Guidebook 10, p. 43-47.

Willis, R.P., 1959, Upper Mississippian-Lower Pennsylvanian stratigraphy of central Montana and Williston Basin: American Association of Petroleum Geologists Bulletin, v. 43. no. 8, p. 1940-1966.

Wilson, J.L., 1955, Devonian correlations in northwestern Montana, in Lewis, P.J., ed., Sweetgrass arch-Disturbed belt, Montana: Billing Geological Society Annual Field Conference Guidebook 6. p. 70-77.
1967, Carbonate-evaporite cycles in lower Duperow Formation of Williston Basin: Canadian Petroleum Geology Bulletin, v. 15, p. 230-312.

1975, Carbonate facies in geologic history: New York, Springer-Verlag, $471 \mathrm{p}$.

Wilson, J.L., and Jordan, Cliff, 1983, Middle shelf, in Scholle, P.A., Bebout, D.G., and Moore, C.H., eds., Carbonate depositional environments: American Association of Petroleum Geologists Memoir 33, p. 297-343.

Wilson, M.D., 1985, Origin of Upper Cambrian flat pebble conglomerates in the northern Powder River Basin, Wyoming, in Longman, M.W., and others, eds., Rocky Mountain carbonate reservoirs: Society of Economic Paleontologists and Mineralogists Core Workshop 7, p. 1-50.

Windley, B.F., 1977, The evolving continents: New York, John Wiley and Sons, 385 p.

Winston, Don, 1988, Proposed intracratonic setting of Western U.S. Middle Proterozoic basin: Geological Society of America Abstracts with Program, v. 20, no. 6, p. 474-475.

Witzke. B.J., 1980, Middle and Upper Ordovician paleogeography of the region bordering the Transcontinental arch, in Fouch, T.D., and Magathan, E.R., eds., Paleozoic paleogeography of the west-central United States: Rocky Mountain Section, Society of Economic Paleontologists and Mineralogists West-Central United States Paleogeography Symposium 1, p. 1-18.

Workman, L.E., and Gillette, Tracey, 1956, Subsurface stratigraphy of the Kinderhook Series in Illinois: Illinois Geological Survey Report of Investigations 189, 46 p.

Wyoming Geological Association Technical Studies Committee, 1965. Geologic history of the Powder River Basin: American Association of Petroleum Geologists Bulletin, v. 49, no. 11, p. 1893-1907.

Young, F.G., 1979, The lowermost Paleozoic McNaughton Formation and equivalent Cariboo Group of eastern British Columbian-Piedmont and tidal complex: Geological Survey of Canada Bulletin 288, $60 \mathrm{p}$.

Zapp, A.D., 1957, White River uplift section, in McKee, W.D., ed., Colorado measured sections: Rocky Mountain Association of Geologists, p. 46-49.

Ziebarth, H.C., 1964, The Tyler Formation of southwestern North Dakota, in Leskela, Willard, and others, eds., Third International Williston Basin Symposium Proceedings: Billings Geological Society, North Dakota Geological Society, and Saskatchewan Geological Society, p. 119-126.

Ziegler, Willi, 1959, Conodonten aus Devon und Karb Südwesteuropas und Bemerkungen zur bretonischen Faltung: Neues Jahrbuch fur Geologie und Paläeontologie, Monatschefte, Schweizerbart, Jahrestagung 1959, no. 7, p. 289-309.

1962. Taxionomie und Phylogenie Oberdevonischer Conodonten und ihre stratigraphische Bedeutung: Hessischen Landesamt Bodenforschung Abhandlungen, v. 38. p. 1-166. 